\title{
Chicago's Irish Nationalists, 1881-1890
}

\author{
Michael F. Funchion \\ Loyola University Chicago
}

Follow this and additional works at: https://ecommons.luc.edu/luc_diss

\section{Recommended Citation}

Funchion, Michael F., "Chicago's Irish Nationalists, 1881-1890" (1973). Dissertations. 1350.

https://ecommons.luc.edu/luc_diss/1350

This Dissertation is brought to you for free and open access by the Theses and Dissertations at Loyola eCommons. It has been accepted for inclusion in Dissertations by an authorized administrator of Loyola eCommons. For more information, please contact ecommons@luc.edu. (c) $($ ) $(9)$

This work is licensed under a Creative Commons Attribution-Noncommercial-No Derivative Works 3.0 License. Copyright (C) 1973 Michael F. Funchion 
IOYOLA UNIVERSITY

CHICAGO, IILINOIS

CHICAGO'S IRISH NATIONALISTS, $1881-1890$

A Dissertation Submitted To The Faculty of The History Department In Partial Fulfillment of The Requirements For The Degree of Doctor of Philosophy

By

Michael F. Funchion

January 31, 1973 


\section{TABLE OF CONTENTS}

\section{Chapter}

I. THE IRISH COMMUNITY IN CHICAGO, 1833-1890 . . . . . . . . • • . • •

II. THE DEVELOPMENT OF IRISH-AMERICAN NATIONALISM IN CHICAGO

III. IRISH NATIONALISTS AND AMERICAN POIITICS • • 82

IV. THE CLAN-NA-GAEI AND THE STRUGGLE FOR AN IRISH NATION . . . . . . . . 116

V. A HOUSE DIVIDED . . . . . . . . . . . 171

VI. THE MURDER OF DOCTOR CRONIN . . . . . . 223 VII. CONCLUSION . . . . . . . . . . . . 262 BIBLIOGRAPHY ............ 268 
CHAPTER I

THE IRISH COMMUNITY IN CHICAGO, $1833-1890$

of all the interdependent forces such as urbanization, industrialization, and the transportation revolution, which transformed nineteenth century America from a minor agricultural country into a world power, there is perhaps none so dramatic as the vast migration of peoples from Europe to the United States. Between 1820, the year immigration statistics were first recorded, and the end of the century over seventeen million Europeans left their native towns and villages to try their hands at making a new life across the ocean. Of the total number who left the old world in those eighty years. Ireland, whose population never exceeded nine million, contributed four million souls. No other country in Western Europe lost such a high percentage of its population through immigration. ${ }^{1}$

During colonial times there had been, of course, a significant stream of immigration from Ireland to America. Unlike the predominantly Catholic immigration of the nineteenth century, however, this exodus was composed largely of Presbyterians from the North of Ireland. Discontented with the land system and the economic restrictions of

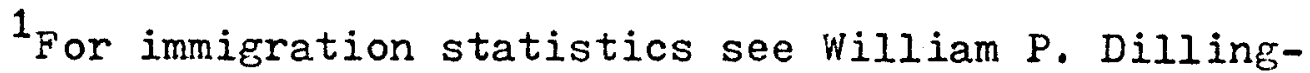
ham, Reports of the Immigration Commission, Vol. III, Statistical Review of Immigration, 1820-1910 (Washingtons Government Printing Office, 1911), pp. 4-43. 
British mercantilism. Irishmen of Scots origin began to leave Ulster on a large scale around 1715. At first they tended to settle in New England villages like Derry, New Hampshire and Belfast, Maine, but by 1740, the climate of the Puritan colonies had become somewhat hostile to the Irish, so that most of Ulster's immigrants preferred Pennsylvania. From Pennsylvania many of these hardy souls moved into the western regions of Virginia and the Carolinas, where they played a significant role in the frontier movement.

Immigration from Ireland continued during the years after American independence, but the volume remained low until the end of the Napoleonic War in 1815, when a noticeable increase took place. In the fifteen years after the Congress of Vienna approximately 85,000 Irishmen, still mainly Protestant, journeyed across the ocean to America; during the years from 1830 until the Great Famine about a half million Irish immigrants, chiefly Catholics, arrived in the United States. ${ }^{2}$ As the leading authority on preFamine immigration has said, "from 1830 onwards the Irish emigrant becomes a recognized and important factor in American economic and social history." 3

Though several factors were responsible for this

${ }^{2}$ William F. Adams, Ireland and Irish Emigration to the New World from 1815 to the Famine (New Haven: Yale University Press, 1932), pp. 118, 191, 221; Marcus Hansen, The Atlantic Migration, 1607-1860 (New York, Harper and Row, 1961), p. 134 .

${ }^{3}$ Adams, Ireland and Irish Emigration, p. 160. 
sudden and dramatic rise in Irish immigration, most of them centered around one fundamental problem -- overpopulation. In the century after 1750 there had been a significant increase in the population of Ireland; the number of inhabitants had grown from a little over three million in 1750 , to eight million by 1840 . This rapid demographic expansion (which might have proved a boom for a nation in the process of industrialization) spelled disaster for Ireland's overwhelmingly agricultural economy. Since the industrial revolution had largely passed Ireland by (save for the northeastern corner), it had no growing industrial centers to support its surplus rural population. Some Irish did manage to immigrate to English and Scottish cities prior to 1815, but the majority continued to stay at home. Plots of land, already pitifully small, were constantly subdivided to take care of the increasing number of peasants. The problem of the Irish peasant was compounded by the fact that he lived under the most despicable land system in Western Europe. Except for Ulster and a few other isolated areas, Irish tenant farmers had no guarantee that they would be permitted to keep their few acres. At the expiration of a lease, the landlord could auction off the holding to the highest bidder and evict the present occupant. With so little land available, this system tended to raise the rents to unjust amounts. Profits from normal agricultural goods such as grain and livestock went to pay the landlords, many of whom lived in England; the farmer and his family 
had to depend on potatoes for their food. 4

This inefficient agricultural system continued on without any radical changes until the end of the Napoleonic War when certain economic and political changes occurred. making it desirable that landlords consolidate their holdings and reduce the number of tenants. The readjustment of the British economy after peace in 1815, and the repeal of the corn laws the following year resulted in a drastic decline in the price of Irish grain products on the English market. Since it was no longer profitable for landlords to permit numerous tenants to grow corn, many were evicted and their small plots of arable land turned into pastures. The disfranchisement of forty shilling freeholders following Catholic Emancipation in 1829 -- they were no longer useful at election time -- increased the incentive for evictions. Similarly, the introduction of the poor law to Ireland in 1838, which placed a good deal of the burden for the poor on the landlords, spurred wholesale clearances of tenants. 5 These evictions, as tragic as they were, did not have an immediate and direct effect upon immigration to the United States until the latter part of the thirties. In the decade after the Congress of Vienna some povertystricken tenants managed to travel to America (some with

4 For a history of the land problem see John Pomfret, The Struggle for Land in Ireland (Princeton: Princeton University Press, 1930).

5Adams, Ireland and Irish Emigration, pp. 163-65, 215: Hansen, The Atlantic Migration, pp. 133-34. 
the financial support of landlords eager to consolidate their holdings), but by and large the very poor classes could not afford the passage. Prior to 1835, the vast majority of Irish immigrants were small farmers and artisans who saw a bleak future in Ireland and left the country while they still had a chance. However, after 1827 when transatlantic fares became cheaper because of the repeal of the more stringent British passenger acts, there was a gradual growth in the poorer class of immigrants. By 1840 , unskilled laborers made up the bulk of Irish immigrants. Besides cheaper rates, the exodus of the lower classes was aided by increased landlord assisted immigration and by the constantly expanding number of Irish-Americans, sending back passage money to relatives and friends in Ireland. 6

The pre-Famine immigration, however, was mild in comparison to the numbers that came during the years immediately following that great disaster. Fleeing from hunger and famine-related diseases that had decimated at least a million of their countrymen, more than one million Irishmen came to the United States between 1846 and 1854. Many of these immigrants never saw America. Some died on disease infested coffin ships, others arrived only to die in port hospitals. Those who did survive nourished within them an almost irrational hatred of England, which they felt was guilty of genocide. The children of this generation made
6Adams, Ireland and Irish Emigration, pp. 103-107. $111-15,160-67, \frac{1}{181,191-200,218-22}$. 
Irish-American nationalism the potent force it was during the $1880^{\prime} \mathrm{s}$. ?

More Irish came to America during the Famine years and the early fifties than in any other part of the nineteenth century. Irish immigration, however, continued steadily throughout the century, ebbing only in times of American depression such as the late fifties and midseventies. Between 1860 and the end of the century close to two million Irishmen entered the United States. Unlike the famine immigrants, these newcomers were better equipped to face life in the New World. They usually had a smattering of education, arrived less destitute, and of ten came out to relatives and friends who quickly established them in decent paying jobs.

The overwhelming majority of Irish immigrants settled in the urban areas of the Northeast. The reasons for this are fairly obvious. First of all, most of the early Irish immigrants, unlike the Germans and Scandinavians, were so poor when they arrived that they could not afford to leave the Eastern seaboard and take up life in the West. Moreover, since the Irish were by nature a friendly people, who lived in close proximity to one another at home, they did not relish the thought of living on the Great Plains, isolated by great distances from their

7 See Cecil Woodham-Smith, The Great Hunger, Ireland 1845-1852 (New York: Harper and Row, 1962); R. D. Edwards and T. D. Williams (eds.), The Great Famine: Studies in Irish History, 1845-1852 (Dublin: Browne and Nolan, 1956). 
closest neighbors. Thus, although many Irish immigrants in the post-Civil War period could well afford to travel west, the majority preferred to settle in the Irish ghettoes of Boston, Philadelphia, and New York, where they had many friends and relatives. And finally, Irishmen tended to shy away from farm life since they lacked the necessary skills to be successful farmers in America.

Despite the concentration of Irish in New England and the Middle Atlantic states, immigration was also important in other areas. Indeed a large number of Irish immigrants settled in the urban and rural areas of the Midwestern and Pacific states. Cities like St. Louis, St. Paul, San Francisco, and Butte had a significant number of Irishmen among their heterogeneous populations. But of all the cities outside the Northeast, it was Chicago which attracted the greatest number of Irishmen and the sons of Irishmen.

No less amazing than the vast migration of Europeans to the United States during the nineteenth century was the spectacular expansion of Chicago. Though there had been occasional settlers living in the Chicago region during the eighteenth century, the city's origin can best be traced back to the establishment of Fort Dearborn in 1803. For a few years there was a small but thriving community of soldiers and Indian traders. But this was completely destroyed by an Indian attack in 1812; it was not until four years later that the second Fort Dearborn was built. And although 
Illinois entered the Union in 1818, the growth of Chicago was painfully slow for several years, partially because of the fear of Indian raids. 8 In 1829, for example, there were still only about thirty inhabitants in Chicago. 9 Conditions changed, however, in 1832 when the Blackhawk Indians agreed to a peace treaty and moved further west. Then in 1836, work was started on the Illinois and Michigan Canal, bringing increased prosperity to the town in the form of speculators and laborers. Despite periodic setbacks caused by economic depressions, the canal was completed in 1848 , providing a continuous waterway between the Great Lakes and the Mississippi River. ${ }^{10}$ This served to make Chicago the center for agricultural products shipped to the East from the West and South and for manufactured goods sent in the opposite direction. During the period the canal was under construction the population increased rapidly. In 1833 , when it became a town. Chicago had a population of 350 . Four years later it was incorporated as a city with 4,000 inhabitants. By the time the canal was completed in 1848 , approximately 20,000 persons were living in the city. 11 The Illinois and Michigan Canal was only a prelude

${ }^{8}$ Bessie L. Pierce, History of Chicago (New York: Alfred A. Knopf, 1937-57), Vol. I, pp. 15-24.

9 Ibid., p. 44.

${ }^{10}$ James $W$. Putnam, The Illinois and Michigan Canal (Chicago: University of Chicago Press, 1918), pp. 93-97; Pierce, History of Chicago, Vol. II, p. 37. 320.

${ }^{11}$ Pierce, History of Chicago, Vol. I, pp. 44, 317, 
of what was to follow. In 1848, the same year the canal was completed, construction began on the Galena and Chicago Union Railway, the first railroad into Chicago. During the next twenty years the railway network expanded enormously, climaxing in the completion of the transcontinental railroad in 1869.12 As a result Chicago became the railroad center of the nation, and the leading commercial city of the Middle West. From the Great Plains grain products flowed into Chicago, where speculators on the Board of Trade and warehousemen made fantastic profits before shipping them to the East and Europe. As railways mushroomed, the livestock trade became increasingly important in Chicago. With the introduction of the refrigerated boxcar, the meatpacking industry, which had really begun to flourish with the railroad expansion of the fifties and sixties, received great impetus in the years after 1870. Besides meatpacking and the grain trade, many other diverse industries sprang up in this new industrial center; the lumber trade, various foundries, and the manuracture of agricultural machinery, to name only a few, became vitally important to the rapidly expanding city. 13

The increase in the population of Chicago after the completion of the first railroad in 1848, was nothing short of phenomenal. Despite two severe depressions in the late

${ }^{12}$ Ibid., Vol. II, pp. 35-76.

13 For an account of the various industries in Chicago see Ibid., Vol, II, pp. 77-117. 
fifties and mid-seventies and the great fire of 1871 , Chicago's 30,000 inhabitants in 1848 increased to almost 300,000 by 1870, to half a million by 1880, and to over a million by the end of the next decade. Meanwhile, the area of the city expanded from fourteen square miles in 1850, to almost 180 square miles in 1890 (well over half of this was added by the annexation of 1889).14

The growth of Chicago's population was the result of natural increase, migration from within the United States, and foreign immigration. In the last decades of the century the first of these factors was the most significant, but in the early years of the city it was the influx of foreigners which contributed most to its growth. In 1850, for example, slightly over half of Chicago's inhabitants had been born outside the United States. ${ }^{15}$ Though the foreign born population continued to grow in terms of absolute numbers during the subsequent years, it declined relatively. Thus, by 1890 only 41 percent of Chicago residents had been born abroad. We should not, however, interpret this drop to mean that the old native Anglo-Saxon stock increased. Rather it was the sons and daughters of immigrants who were boosting the figures for the native population. In 1890, the foreign born and those with at least one foreign born parent con-

14 M. H. Putney, Real Estate Values and Historical Notes of Chicago (Chicago: n.p.1900), pp. 109-10, 118.

15 Pierce, History of Chicago, Vol. I, appendix, p. 418 . 
stituted almost four-fifths of the population of Chicago. 16 Prior to 1890, the foreign population of Chicago came mainly from northern and western Europe. In the early years the Irish supplied the greatest number of settlers. The census of 1850 reveals that out of a total population of 30,000 there were 6,000 (20 percent) Irish-born. The Germans, by contrast, constituted 17 percent of the total. 17 But during the next forty years the Germans were the leading immigrant group in Chicago. By 1890, they accounted for over one-third of the foreign born population; the Irish made up only about 16 percent. In fact, in 1890, there were slightly more Scandinavian-born Chicagoans than Irish natives. 18

The Germans also led in the foreign stock category (that is, foreign born and natives with at least one foreign born parent). In 1890, over one-third of the foreign stock was German, while one-fifth was Irish. The Scandinavians only accounted for 10 percent of the total. 19

Though overshadowed by the Germans the growth of the Irish population during the four decades between 1850 and 1890 was significant. The 6,000 Irish natives in 1850

$16_{\mathrm{U}}$. S. Dept. of the Interior, Census office, Compendium of the Eleventh Census, 1890. Vol. II, pp. 604II, VoI. III, p. 75 . p. 418 .

${ }^{17}$ Pierce, History of Chicago, Vol. I, appendix, pp. 604-11.

${ }^{18}$ Compendium of the Eleventh Census, 1890, Vol. II, ${ }^{19}$ Ibid., Vol. III, p. 83. 
increased to nearly 20,000 by 1860 ; jumped to almost 40,000 by 1870; grew more slowly to 44,000 in 1880, because of the depression during the mid-seventies; but recovered the next decade, rising to over 70,000 by 1890.20 If native Americans with at least one Irish-born parent are added to those born in Ireland, the total Irish stock in 1890 reaches almost $170,0000^{21}$ Furthermore, unofficial estimates of the total Irish population of Chicago, including third generation and beyond, placed the figure at about $215,0000^{22}$ In comparing it to other American cities, Chicago in 1890 ranked fourth in the number of Irish foreign stock, behind New York, Brooklyn, and Philadelphia, and fifth in the number of Irish-born, being surpassed by the above three cities and Boston. Relatively speaking the Irish community in Chicago was smaller than those in the four other cities. In 1890, individuals of Irish parentage made up about one-fourth the total population of New York, Brooklyn, and Philadelphia, and over one-third that of Boston, whereas in Chicago they accounted for only about 15 percent of the total population. Iikewise, it was only in Chicago that the Germans seriously outnumbered the Irish, there being over twice as many Germans as Irishmen. In New York

${ }^{20}$ Ibid., Vol. II, pp. 604-11; Pierce, History of Chicago, Vol. I, appendix, p. 4I8, Vol. II, appendix, p. 482, Vol. III, appendix, p. 516. p. 83 . ${ }^{21}$ Compendium of the Eleventh Census, 1890, Vol. III, 22 George E. Moran, Moran's Dictionary of Chicago and Its Vicinity (Chicago, G.E. Moran, 1892), pp. 165-66. 
and Brooklyn the Germans and the Irish were about equal, though the Germans did have a slight edge in both cities. In Philadelphia the Irish surpassed the Germans by a fair margin, while in Boston there were over seven times as many Irishmen as Germans. 23 The numerical ratio of the Irish to other foreign groups and to the native Americans was as an important a factor in the development of the Irish communities in these cities as were economical opportunities, geographical location, and time of entry.

Irish antiquarians were quick to point out that the real father of Chicago was neither Jean Pierre du Sable, the black eighteenth century settler, nor John Kinzie, a trader who arrived in 1804, but an Irish-born Catholic, Captain John Whistler, the builder and first commander of Fort Dearborn. ${ }^{24}$ A more fascinating character of Irish descent roaming about Chicago during these early years was Billy Caldwell, the son of an Irish-born officer in the British army and an Indian mother. Educated by the Jesuits in Detroit, he served as an aide-de-camp to Tecumseh. About 1820, Caldwell settled in Chicago with his tribe, the Pottawatomies, and remained there until the early thirties

\footnotetext{
${ }^{23}$ Compendium of the Eleventh Census, 1890, Vol. III, p. 83.

$24 \mathrm{Joseph} \mathrm{J}$. Thompson, "The Irish in Chicago," Illinois Catholic Historical Review, Vol. II (1920), pp. 45859; John P. McGoorty, "The Early Irish of Illinois," Transactions of the Illinois state Historical society. Vol. XXXIV, $(1927), \mathrm{p} .63$.
} 
when they signed a treaty and moved west. 25

The first great influx of Irish into Chicago, however, came with the building of the Illinois and Michigan Canal in 1836. Since the Irish had made their reputation as laborers on public works projects in the East, a special effort was made to recruit them for work in Illinois. Advertisements were made in the East promising good wages and steady work. Many of those who came had experience working on canals like the Erie Canal in New York, while others were met by agents as they stepped off the boat from Ireland. By the end of the year about 350 men were working on the canal and they continued to come in the years ahead. Soon shanties were strewn all along the route of the canal from La Salle to Chicago. 26

Iife in these communities was far from pleasant, particularly for men with families. The shanties were uncomfortable to say the least, while frequent epidemics caused considerable hardship. The laborers worked for contractors who drove them hard and often failed to pay them their proper wages. Contractors frequently gave the

\section{5"Chicago's Irish Pioneers," Chicago Times-Herald,} oct. $20,1895$.

$$
26 \text { George J. Fleming, "Canal at Chicago," (Ph. D. }
$$
Dissertation, Catholic University of America, 1950), pp. 103, 126; William J. Onahan, "Irish Settlement in Illinois," Catholic World, Vol. XXXIII (1881), p. 158; John J. McGovern, "History of the Catholic Church in Chicago," Souvenir of the Silver Jubilee in the Episcopacy of His Grace the Most Rev. Patrick Augustine Feehan, Archbishop of Chicago (Chicago, n. p., 1891), p. 14; George Potter, To the Golden Door (Boston: Little Brown, 1960), pp. 173, 184, 318. 
men whiskey to induce them to work more quickly, but more often than not it made them belligerent, and at times they ended up fighting with each other. The brawls were often between groups from different parts of Ireland. In the summer of 1838, for example, Corkmen and Ulstermen engaged in such a serious fight that the sheriff and state militia had to be called in to put down the riot. A number of Irishmen were killed in the subsequent skirmish. 27

A critical time for canal workers came in 1842 , when work on the canal had to be suspended because of economic difficulties. Lacking money, the company gave the laborers a script which could be exchanged for land. Although some of the workers took the land and became farmers along the route of the canal, many sold their property to speculators and settled in Bridgeport, the eastern terminus of the canal, where a good number of canal laborers were already living. 28

Bridgeport at that time was a village situated on the east bank of the South Branch of the Chicago River, just outside the city limits of Chicago. 29 It had all the unde-

\section{Fleming, "Canal at Chicago," pp. 126-29; Potter,} To the Golden Door, p. 320; "Our Irish," Chicago Tribune, April 19, 1874; Onahan, "Irish Settlements in IIIinois," p. 158.

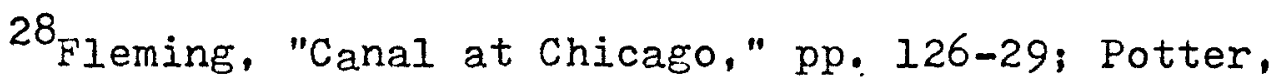
To the Golden Door, p. 320; "Our Irish," Chicago Tribune, April 19, 1074; Onahan, "Irish Settlements in Illinois," p. 158.

${ }^{29}$ Bridgeport is usually defined as the area bounded on the north by Twenty-Second Street and the South Branch of the Chicago River, on the east by Pennsylvania Railroad tracks, on the west by the South Branch, and on the south 
sirable characteristics of the canal settlements. One writer claimed that "both morally and physically it [was] a cesspool, a stench in everybody's nostrils, especially when there is a breeze from the southwest. "30 Most Irish workers lived between Archer Road and the river in ill-constructed shanties, built along unpaved and filthy streets. Numerous cabbage patches dotted the landscape; Bridgeport residents grew cabbage not only for their own needs, but also shipped them as far south as New Orleans. The men for the most part worked as unskilled laborers on the canal or in meat packing plants, brick yards, and lumber yards. Since much of this work was seasonal (meat packing plants only operated during the winter months) there was considerable periodic unemployment. 31

Besides Bridgeport the Irish settled in the city proper. On the South Side they lived in various patches along both sides of the South Branch of the Chicago River, while on the North Side they were clustered in Kilglubbin, an area between Erie Street and the Chicago River, bounded on the west by the North Branch and on the east by Wells Street. From Kilglubbin they migrated to Goose Island, a

by Pershing Road (Thirty-Ninth Street). 30 F. F. Cook, Bygone Days in Chicago (Chicago: A. C. MeClurg and Co., 1910), pp. 179-80.

31 Joseph Hamzik, "Gleanings of Archer Road" (Typed MSS, Library of the Chicago Historical Society), pp. 3?41, Cook, Bygone Days in Chicago, pp. 179-80; Local Community Research Committee, Chicago Communities (Typed copy, Chicago Historical Society), Vol. VI, "Bridgeport," Documents Nos. $1,2,3$. 
section to the northwest, surrounded by the North Branch of the Chicago River and an artificial canal. 32 In all of these ghettoes the Irish endured the same poverty and unsanitary conditions as their cousins in Bridgeport. 33 one early North Side resident recalled, for example, that there were countless mud holes scattered throughout Kilglubbin and that pigs roamed about the streets eating garbage. 34 Similarly, a newspaper reporter visiting Goose Island during the sixties described three room shanties in which geese, hens, and pigs shared the living quarters with the family. 35 And if living conditions were abominable, there was also much lawlessness. In Conley's Patch on the South Side gambling and prostitution flourished, while Kilglubbin became notorious for brawls between Connachtmen and Munstermen. 36

32 Charles S. Winslow, "Historic Goose Island" (Typed MSS, Chicago Historical Society), pp. 1-13; Ruth M. Piper, "The Irish in Chicago, 1848-1871" (M.A. Thesis, University of Chicago, 1933), p. 5; Local Community Research Committee, Chicago Communities, Vol. III, "Lower North Side," Doc. No.23.

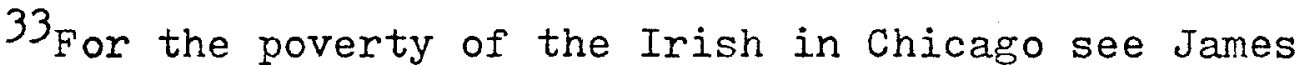
Brown, The History of Public Assistance in Chicago, 1833 to 1893 (Chicago: University of Chicago Press, 1941), pp. 1213; H. W. Zorbaugh, The Gold Coast and the Slum: A Sociological Study of Chicago's ivear North Side (Chicago: University of Chicago Press, 1929), pp. 19, 22; Piper, "The Irish in Chicago, 1848-1871," p. 5; Winslow, "Historic Goose Island," pp. I-13; Emmet Dedmon, Fabulous Chicago (New York: Random House, 1953), p. 32; Pierce, History of Chicago, Vol. I, p. 74 .

34 Harriet Rosa, "Reminiscences and Account of Chicago History," MSS, Chicago Historical Society.

$$
\begin{aligned}
& 35 \text { Winslow, "Historic Goose Island," p. } 13 . \\
& 36 \text { Thompson (ed.), The Archdiocese of Chicago (Des }
\end{aligned}
$$

Plaines, Ill., St. Mary's Training School Press, 1920), p. 343; Dedmon, Fabulous Chicago, p. 32; "Our Irish," Chicago 
Although these early ghettoes were still centers of Irish settlement during the $1880^{\prime} \mathrm{s}$, the Irish began to spread out into other sections of the city in the years following the Civil War. They were most sparsely settled in the area north of Chicago Avenue, except for a few isolated sections like Goose Island. The West Side had a considerable number of Irish, but they were mainly concentrated in the area between Ashland Avenue and the North and South Branches of the Chicago River; native Americans dominated the area west of Ashland Avenue and north of the IIlinois and Michigan Canal. 37 on the South Side a large number of Irish moved into the Stock Yards district after the opening of the Union Stock Yards in 1866, and particularly after 1871, when the fire resulted in the relocation of many people in more northern neighborhoods. 38 Irishmen were scattered also throughout other areas on the South side, most notably railroad workers living in close proximity to their work. 39

Tribune, April 19, 1874.

37 Based on an examination of the City of Chicago, Board of Education, School Census of the City of Chicago, Taken May, 1884. Total Population of the City. Over 21 Years and Under 21 Years of Age. By Ward and Division of the City. (Chicago, 1884), pp. 20-31.

38 Dillingham, Reports of the Immigration Commission, Vol. XIII, Slaughtering the Neat Packing, p. 199; Local Community Research Committee, Chicago Communities, Vol. VI, "Canaryville," Document Nos. 1, la, 7; J. J. O'Toole, "The Story of Back of the Yards," Journal of the Town of Lake, Sept. 14, 1939; Charles J. Bushnell, The Social Problem at the Chicago Stock Yards (Chicago: University of Chicago Press, 1902), p. 34. 39 See Thompson, The Archdiocese of Chicago, p. 397; 
In the $1880^{\prime} \mathrm{s}$, therefore, the majority of the Irish were living on the South, Near West, and Near North Sides. But in looking at the distribution of the Irish population during this decade, it is surprising to observe how few of the Irish were living in real ethnic ghettoes. According to the school census of 1884, there was not one of the eighteen wards in which the Irish (second generation included) constituted a majority. They came closest in the Fifth Ward (Bridgeport made up the major part) and in the Eighth Ward on the Near West Side. In both of these they constituted slightly less than 40 percent of the population. In the Seventeenth Ward, which included Kilglubbin, they accounted for only about 30 percent of the total number of residents. In all of these once heavily Irish areas, Germans, Swedes, and other groups had been drifting in since the late $1850^{\circ} \mathrm{s}$. Thus in 1884, Germans accounted for 30 percent and 20 percent of the inhabitants in the Fifth and Eighth Wards respectively, while Swedes made up about 30 percent of the population of the Seventeenth Ward. Similarly, the statistics for the Stock Yards district (outside the city limits until 1889) during the next decade demonstrate that the Irish accounted for slightly less than one-third the population, while Germans and native Americans respectively made up one-quarter and one-fifth of the total. In subdividing the wards into smaller districts we find a sim-

Local Community Research Committee, Chicago Communities, Vol. V, "Washington," Doc. No. I, "West Englewood," Doc. Nos, $1,3$. 
ilar lack of Irish concentration. Of the 303 census canvass districts the Irish, first and second generation included, had a majority in only eleven, and in only one of these did they make up more than 70 percent of the population. Irish patterns of settlement were somewhat different to other groups. Though native Americans, Germans, and the newer immigrant groups were more dispersed than might be supposed, they were generally far more cohesive than the Irish. Along with the British, the Irish were the least "ghettoized" group in Chicago. 40

Therefore, rather than living in exclusively Irish areas, the Irish of the $1880^{\prime} \mathrm{s}$ resided in multi-ethnic lower class sections, somewhat comparable to today's Uptown where poor Appalachian whites, American Indians, and Latins live together, despising one another yet experiencing the same economic hardships. One might more properly classify these neighborhoods as economic rather than ethnic ghettoes. Kilglubbin and Bridgeport were improved over what they had been thirty years previous. but during the eighties they were still poor neighborhoods. 41 And even some of the newer

\section{Based on School Census of the City of Chicago,} 1884, pp. 20-31.

${ }^{41}$ See Local Community Research Committee, Chicago Communities, Vol. VI, "Bridgeport," Doc. No. 4; Zorbaugh, The Gold Coast and the SIum, pp. 30-34; Frank Conlan to Philip Loeb, April 20, 1954, Frank Conlan Papers, Chicago Historical Society; Dillingham, Reports of the Immigration Commission, Vol, I, Immigrants in the Cities, pp. 253-54; Charles F. Fanning, Jr., "Wr. Dooley's Bridgeport Chronicle," Chicago History, Vol. II (1972), pp. 47-57. 
areas were known for their poverty. In the Stock Yards district, for example, workers earned relatively low wages and lived in sub-standard housing. The streets were unpaved and filthy in sharp contrast to those of Hyde Park, the prosperous district to the east. There was much gambling and drunkeness and the crime rate was fairly high. 42

Some Irish did of course live in good neighborhoods and in the years after 1890, as the new immigrants entered the city, more and more Irish moved to better areas like Hyde Park, Englewood, Washington Park, Austin, and Rogers Park, to name only a few. But during the eighties the majority still lived in the old dilapidated areas. On the other hand, while numerous native Americans and Germans lived in poor neighborhoods, a higher percentage of Germans, and a far greater proportion of native Americans resided in the middle income districts on the fringes of the city. 43 Poor relief statistics provide another indication of the relative poverty of the Irish. In 1870, for example, almost half of the 14,000 Chicagoans receiving outdoor pubIic assistance were Irish-born, and this at a time when they comprised only 13.4 percent of the population. The Germanborn, representing 17 percent of the city's inhabitants, accounted for one-fifth of those on relief, while the number

\section{Bushnell, The Social Problem at the Chicago Stock} Yards, pp. 39-51; Local Community Research Committee, Chicago Communities, Vol. VI, "Canaryville" Doc. Nos, la, 7. $21-30$

${ }^{43}$ Based on School Census of the City of Chicago, pp. 
of native Americans on relief was far less than what their percentage of the city population might indicate. $44 \mathrm{sim-}$ ilarly, statistics of the Chicago Relief and Aid Society for the late eighties indicate that the Irish had far more than their percentage receiving assistance from this society. 45

Another indication of the low economic level of the Irish was their occupational distribution. The Irish, for the most part, worked as unskilled laborers; in 1870, for example, more than half the Irish-born working force was unskilled, compared to only one-third of the German and onefourth of the American. 46 In the 1890 census, 34 percent of the Irish-born male labor force was listed as unspecified laborers, in contrast to only 18 percent of the German-born and 6 percent "native of native parentage." 47 The Irish worked in such places as meatpacking plants, factories, on the railroads, or as policemen, bartenders, and domestic servants. 48 They were poorly represented in the upper ranks

44 Brown, The History of Public Assistance in Chicago, pp. 14-15.

45 Thirtieth Annual Report of the Chicago Relief and Aid Society (oct. 31, 1886 - oct. 31, 1887), p. 20; ThirtyFirst Annual Report of the Chicago Relief and Aid Society loct. 31, 1887 - oct. 31, 1888), p. 17.

${ }^{46}$ Pierce, History of Chicago, Vol. II, pp. 151-52.

47 Based on statistics in U.S. Dept. of the Interior, Census Office, Eleventh Census, 1890, Population, pp. 650-51.

${ }^{48}$ See table on occupational distribution of Chicagoans, 1880-1890, Pierce, History of Chicago, Vol. III, appendix, p. 518 . 
of the professions and business. A survey of the ethnic origin of Chicago physicians during the 1880's shows that only five out of 161 were of Irish Catholic stock. Similarly, only 30 out of 494 leading lawyers were of Irish origin; six out of 222 members of the Board of Trade; two out of 42 bankers, four out of 44 building contractors. 49 This is not to say there were not prominent Irishmen in the professions or in business. The Kilkenny-born Cudahy brothers, Michael and John, started a meatpacking business in Milwaukee and then came to Chicago where they made a fortune in the industry. 50 Patrick Touhy came from Ireland, married the daughter of Philip Rogers, and thereby acquired an extensive tract of land south of Evanston. He later became a millionaire, selling the property to con-

\section{These surveys do not include all members of the} businesses or professions but only those distinguished enough to be listed in biographical histories. All the surveys except that on the legal profession are based on biographical sketches in A. T. Andreas, History of Chicago, (Chicago: A.T. Andreas Co., 1884-86), Vols. II, III. The survey of the lawyers is based on biographical sketches in Bench and Bar of Chicago (Chicago: American Biographical Publishing Co., 1883).

The census of 1890 shows a somewhat similar trend for the Irish, excluding the second generation. According to the statistics the Irish-born comprised 9 percent of the total labor force, but only 4 percent of the lawyers, 2 percent of the doctors, 3 percent of the bankers, bank officials and brokers. Unfortunately, the statistics for second generation Irishmen are not given. It is probable that if they were included the Irish would rank higher, but as the above survey indicates the Irish, second generation included, did not put much of a dent in the upper echelons of these professions and businesses. Percentages based on Eleventh Census, 1890, Population, pp. 650-51.

${ }^{50}$ Charles Ffrench (ed.), A Biographical History of the American Irish in Chicago (Chicago: American Biographical Publishing Co., 1897), pp. 176-81, 192-98. 
tractors engaged in building the then growing village of Rogers Park. 51 Similarly, John M. Smyth, born at sea as his parents were immigrating to America, achieved financial success in the furniture business, while Daniel Corkery, a Massachusetts native reared in Chicago, became a prominent coal merchant. 52

These individuals, however, were the exceptions. Most Irishmen remained on the lower rung of the economic ladder. In the eighties, when the newer immigrant groups still did not exert any great impact on the city, the Irish stood in an unfavorable position with the two other chief groups, the native Americans and the Germans. It is clear that the Irish had not gained much economically by growing up with their city. In the early years when Chicago's frontier conditions should have acted as a leveler on the various elements of the population, the majority of Irish were so destitute and in other respects so ill-equipped that they could not take advantage of the favorable circumstances. It is true, of course, that the economic gulf between the Irish and the Protestant Americans was not as great in Chicago as it was in some of the Eastern cities, for the raw conditions of the West had done a certain amount of equalizing. Chicago had no high society nor leisure class in these days, and most individuals, even those with

51 John Drury, "Old Chicago Neighborhoods: VII, Rogers Park," Landlords Guide, Nov. 1947, pp. 22-23, 26. 52 Ffrench, A Biographical History of the American Irish in Chicago, pp. 10-15, 426-29. 
considerable wealth, often did hard work. 53 Moreover, despite the poverty-stricken condition of most Irish, a number of them achieved success.

As the decades passed by and the economic condition of the Irish improved, paradoxically, the gulf between the two groups in many ways widened. With the passing of frontier conditions, Chicago had developed an elite, mainly Protestant, and one in which the Irish played a miniscule role. Though Chicago's elite was more dependent on wealth than family lineage (as in Boston), these families had gradually acquired most of the trappings of high society; they lived in grand houses, belonged to exclusive clubs, and sent their children to prestigious schools back East. 54 A contemporary writer aptly summed up the increasing stratification of Chicago society: "In olden times the Servants sat at the table with the family, they were treated something like human beings, . . in many cases almost as equals. Now the kitchen is far away from the parlor." 55

Beneath the upper echelon of Chicago society were

53 Pierce, History of Chicago, Vol. II, pp. 190-91.

54 H. D. Duncan, The Rise of Chicago as a Literary Center from 1885 to 1920: A Sociological Essay in American Culture (Totowa, New Jersey: The Bedminster Press, 1964), p. 33. For a good popular account of high society in Chicago see Dedmon, Fabulous Chicago, pp. 113-80. For details on the exclusive clubs see Andreas, History of Chicago, Vol. III, pp. $404 \mathrm{ff}$.

55 Robert Ingersoll in the preface of the anonymous novel For Her Daily Bread, cited in Duncan, The Rise of Chicago, pp. 22. 
the ordinary Protestant Americans, most of whom lived in better neighborhoods and had better paying and more respectable jobs than the Irish. And then there were the Germans; though in economic terms they were probably closer to the Irish than the Yankees, they had, nonetheless, achieved a financial status superior to the Irish. 56

The economic position of the Irish in Chicago, therefore, helped to separate them from the Protestant American community, a most important factor in maintaining Irish group identity during this period. Their low economic status also tended to preserve their massive inferiority complex, nurtured during the centuries of British oppression. John Finerty, editor of the Chicago Citizen, aptly expressed the feeling of shame and inferiority of many Irishmen in Chicago when he urged prospective immigrants to remain in Ireland. In America, he claimed, the Irishman "is nothing but a poor emigrant, who is left to paddle his own canoe as best he may, and who, however, delicately nurtured at home, must take, at last, to the pick and shovel, perhaps to the recruiting office, or become a charge upon the country." 57 As we shall see in the next chapter, sentiments like these would have a direct bearing on the development of Irish nationalism in Chicago.

The most important institution in maintaining a

${ }^{56}$ See table of occupational distribution of Chicagoans 1880-90; Pierce, History of Chicago, Vol. III, appendix, p. 518; Eleventh Census, 1890, Population, pp. 650-51.

57 Chicago Citizen, July 11, 1885. 
separate Irish identity, however, was the Catholic Church. Centuries of religious persecution had ingrained in the Irish a deep sense of loyalty toward the Church of Rome, a feeling that remained intense when they came to Protestant Anglo-Saxon America. By far the Irish were the most significant element in the formation of American Catholicism.

In 1833, when Chicago became a town, a group of Catholics, mainly French-Canadians and French-Indians, asked the Bishop of St. Louis to send them a priest. Complying with this request, the bishop sent Father John St. Cyr, a Frenchman, who established St. Mary's, the first Catholic Church in Chicago. 58 For the next ten years Americans, Irish, French, and Germans worshipped together in this little church, often getting into disputes as to which language should be used for sermons. Though in the beginning the French were the strongest element, by 1840, the Irish had become the most dominant group, a position they never Iost. 59

By the early forties Illinois had a sufficient number of Catholics to form a separate diocese. Thus, in 1843 , the diocese of Chicago was created and an energetic offalyborn priest from New York, William Quarter, was consecrated its first bishop. Bishop Quarter was to live only another four years, but during this short period he greatly contri-

58 Andreas, History of Chicago, Vol. I, p. 289; G.J. Garraghan, S.J., The Catholic Church in Chicago (Chicago: Loyola University Press, 1921), pp. 45-46. 106.

59Garraghan, The Catholic Church in Chicago, pp. 83- 
buted to the growth of the Church, bringing in numerous priests, building four new churches, and establishing the University of St. Mary of the Lake. 60

Between the episcopacy of Quarter and that of Feehan (1880-1902), the Church grew rapidly with the tremendous influx of Irish and German immigrants. There was a certain amount of friction between the two groups, especially since the Irish were in such firm control of the diocese, but major difficulties were averted by the establishment of separate English-speaking and German-speaking congregations. With minor ethnic groups, however, the language problem could not be settled so easily. For instance, in 1850 Father John Waldron, a native of County Mayo, was assigned to replace a French priest in the mixed Irish and French parish of St. Louis. Finding that the French parishioners were hostile toward him because he could not speak their language, he tried to blunt their criticism by preaching his first sermon in Irish, a language most of the Englishspeaking Irish could not understand. At least, the French could not accuse him of catering to the English-speaking parishioners! 61

If the rivalry between the various ethnic groups caused some dissension in the Church during these years, the string of mediocre and incompetent bishops between Quar-

\section{${ }^{60}$ Ibid., pp. 108-32; "Diary of Bishop Quarter,"} McGovern (ed.), Souvenir of the Silver Jubilee, pp. 65-83. 61 Thompson. The Archdiocese of Chicago, p. 341-343. 
ter and Feehan injured the Church to a greater extent. Quarter's two immediate successors, James Van De Velde (1849-54) and Anthony O'Regan (1854-57), the former a native of Belgium, the latter of County Mayo, were academic types unsuited to the rigors of a frontier diocese. Both had reluctantly accepted their appointments and once in office had continually requested to resign, which they were both eventually allowed to do. 62 The next bishop, James Duggan (1859-69), a County Kildare man, was not so fortunate. He became so insane by 1869 , that he had to be removed, but not before he had caused considerable disruption in the diocese. 63 His successor, Thomas Foley $(1870-79)$, a Baltimorian of County Wexford parentage, was an effective administrator; he did much to clean up the mess left by Duggan and to guide the diocese through the difficult years after the fire. But he was an aloof man who disliked Chicago, and was therefore never close to his priests and people. While on a visit to Baltimore he met a premature death, the only bishop to die in office since Quarter. 64 After more than three decades of these rather undistinghished prelates, Chicago was fortunate that the able

62 Garraghan, The Catholic Church in Chicago, pp. 137-79; McGovern (ed.), Souvenir of the Silver Jubilee, pp. 186-87; "Untold History of Catholic Chicago," Chicago Daily News, Special Supplement, Dec. 1966.

63 Garraghan, The Catholic Church in Chicago, pp. 180-218; McGovern (ed.), Souvenir of the Silver Jubilee, pp. $196-99$.

64 McGovern (ed.), Souvenir of the Silver Jubilee, pp. 202-25; "Untold History of Catholic Chicago." 
Bishop of Nashville, James A. Feehan, was appointed its first Archbishop. Feehan, a County Tipperary native, was a liberal and ecumenical-minded man; he did his best to avoid controversy and concentrated instead on building countless churches and schools. He presided over the archdiocese from 1880 to 1902, a period of tremendous growth, when the newer immigrant groups -- Italians, Poles, Bohemians, and Lithuanians -- were coming in to add another dimension to this IrishGerman Catholic community. National parishes were established for these groups, as they had been for the Germans. Considering all the difficulties he encountered, Feehan did an admirable job in reconciling the diverse national elements in a supposedly universal church. 65

By the turn of the century, then, the Catholic Church in Chicago was a vigorous institution, which through means of national churches had effectively separated the Irish from their fellow non-English speaking Catholics. But more importantly, the Church was also responsible for isolating the Irish from the Protestant American community, and was thereby a most influential factor in maintaining a unique Irish identity. Catholic training had imbued in the minds of Irish-Americans the traditional teaching that the Roman Church was the one true Church, essentially different

65 Cornelius Kirkfleet, The Life of Patrick Augustine Feehan. Bishop of Nashvilie, First Archbishop of Chicago, 1829-1902 (Chicago: Matre and Co., 1922), pp. 1, 34 , $66,158-59,349-53$; "Untold History of Catholic Chicago"; John P. J. Walsh, "The Catholic Church in Chicago and Problems of an Urban Society, 1893-1915" (Ph. D. Dissertation, University of Chicago, 1948), pp. 3-20. 
from Protestant religions. During a Sunday sermon old Father Fitzgerald might exhort his parishioners to be patriotic Americans but he also warned them that there was much in American life that could contaminate their faith. The Church proscribed certain books and plays and urged young boys and girls to attend parish social affairs where they would have a chance of meeting their own kind. Catholics also established their own school system to provide their children with what they considered to be a truly Christian education. Though many Irish Catholics attended public schools, Chicago had a higher proportion of its Catholic children attending parochial schools than any other city in the country. ${ }^{66}$ By separating Catholic children at an early age, these schools served to keep IrishAmericans isolated from the general community. 67

Besides the Catholic Church there were other institutions that helped preserve Irish ethnic identity. There were, of course, the nationalist groups, which we shall discuss in the next chapter, but there were also fraternal organizations like the Ancient Order of Hibernians and the United Sons of Erin Benevolent Society. These societies provided members with a sense of fellowship as

${ }^{66}$ Speech of Judge Moran, McGovern (ed.), Souvenir of the Silver Jubilee, pp. 339-40.

67 For the effect of Catholicism on the attitudes of the South Side Irish some forty years later see James $T$. Farrell, Studs Lonigan: A Trilogy Containing Young Lonigan, The Young Manhood of Studs Ionigan, Judgement Day (New York: New American Library, 1965). 
well as financial aid in times of distress. 68 Military organizations were also popular; they gave Irishmen a chance to express their martial spirit and associate with their fellow countrymen. The first of these, the Montgomery Guards, was established in 1842; others like the Emmet Guards and the Shileds Guards soon followed. ${ }^{69}$ When the Civil War broke out these companies provided much of the manpower for the Irish Brigade (Twenty-Third Illinois Infantry) under the command of Colonel James Mulligan. Along with the Irish Legion (Ninetieth IIlinois Infantry) the Irish Brigade distinguished itself in the war, helping to counteract claims that the Irish were copperheads. 70

Irish identity was also re-enforced by anti-Irish prejudice. Because of its relatively new development, Chicago had quite a different history of nativism than the cities of the East. While anti-Catholic fanatics were burning convents and rioting in Boston and Philadelphia, Chicago was a small western settlement struggling against the rough elements of the frontier. The problems of developing a good harbor, of building a suitable canal, or of filling in marshy ground seemed somewhat more pressing to most Chicago-

${ }^{68}$ Piper, "The Irish in Chicago, 1848-1871," pp. 1015; Sister M. Evangela Henthorne, The Irish Catholic Colonization Association of the United States (Champaign, Ill: Twin City Printing Co., 1932), p. 21. 69 Thompson, "The Irish in Chicago," pp. 472-73; Andreas, History of Chicago, Vol. II, p. 161 .

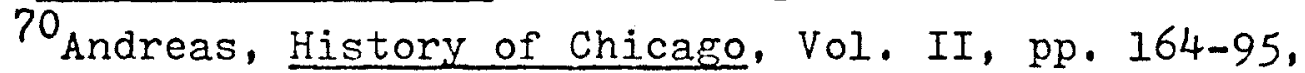
249-52; Garraghan, History of the Catholjo in Chicago, pp. $185-87$. 
ans than the so-called Catholic menace. In fact, during the early years a number of prominent non-Catholics supported the Church. William Newberry and John Scammon gave financial aid to Bishop Quarter; William Ogden, Chicago's first mayor, donated land and money to build the University of St. Mary of the Lake. 71 Bishop Quarter was so amazed at the spirit of good will toward Catholics that shortly after his arrival in Chicago he wrote "that a spirit of great liberality exists towards Catholics in all parts of this state, and in the city a word exasperating or painful to the feelings of Catholics I have never heard uttered. Indeed the citizens appear all like the members of one united and well organized family where each one consults for the benefits and advantage of all."72

But Quarter perhaps overstated his case. Despite the general feeling of good will toward the Irish, there were undercurrents of anti-Catholic prejudice even during these early years. From the time Chicago was incorporated as a city in 1837, the Irish played a significant role in the outcome of elections. Having the right to vote after six months residence and consistantly voting Democratic, often illegally, the Irish antagonized other elements of the population. In 1840, for example, the Chicago American

${ }^{71}$ Garraghan, History of the Catholic Church in Chicago, pp. 114, 134; McGovern, Souvenir of the Silver Jubilee, p. 60 .

72 Quarter to Purcell, Sept. 2, 1844, cited in Garraghan, History of the Catholic Church in Chicapo, p. 109; See also Rosa, "Account of Chicago," MSS, Chicago Historical Society. 
claimed that the Irish had far too much influence in politics. Similarly, the Democratic candidate for Mayor in 1846 felt that foreigners should have to Iive in the United States twenty-one years before they could become citizens and vote. 73 An early Chicago resident aptly summed up the feeling of resentment toward the Irish:
The elections are just over and all the Democrats are elected, Irish and all : . I claim to be a Democrat myself but I do not go for electing Irish Democrats, all the way from old Ireland, to legislate and to execute the laws as though we had no one among ourselves fit for such

The rather mild nativist tones of the thirties and forties became more strident during the fifties. For one thing, the temperance crusade increased its tempo, particularly after 1853, with the formation of the Illinois Maine Law Alliance, which sought to establish prohibition in Illinois. Though much of the opposition to prohibition came from the native born, the chief bulwarks of alcohol in the minds of the reformers were the beer-loving Germans and the whiskey-guzzling Irish. The prohibitionists ran a candi-

${ }^{73}$ Charles Cleaver, "Extracts from Articles which Appeared First in the Chicago Tribune," Mabel McIllvaine (ed.), Reminiscences of Chicago during the Forties and Fifties (Chicago: R.R. Donnelley and Sons, 1913); Pierce, History of Chicago, Vol. I, pp. 377-78, 381-83; Fleming, "Canal at Chicago," pp. 131, 152-53; F.0. Bennett, Politics and Politicians in Chicago (Chicago, 1886), p. 59; See also letter to Elizabeth E.P. Dutton, Aug. 7, 1839, MSS Chicago Historical Society.

${ }^{74}$ Solomon Wills to James B. Campbell, Aug. 12, 1838 , James B. Campbell Papers, Chicago Historical Society. 
date for mayor for some years but were never successful, a fact they attributed to Irish and German influence. 75

Far more formidable than the Illinois Maine Law Alliance was the American Party, more commonly known as the know-Nothings. Decidedly anti-immigrant and antiCatholic throughout much of the nation, the know-Nothings developed in Chicago more as a result of the disruption in the regular political structure than because of nativism, though that was significant also. During the forties Chicago had been strongly Democratic but it was equally adamant in its opposition to slavery. When it became apparent in the early fifties that no true anti-slavery man could remain within the Democratic fold (particularly after Douglas's stand on the Kansas-Nebraska Act) many free soil Democrats left the party of Jefferson and Jackson. Since the Whigs had fallen asunder and the Republican Party had not yet taken a strong hold in Illinois, many of these Democratic pariahs found refuge with the know-Nothings. 76 However, there was also a strong nativist strain in some of these individuals. In 1855, for example, the Know-Nothings managed to capture a majority of the city council and elected Levi Boone as Mayor. Once in power they quickly passed laws requiring applicants for municipal jobs to be born in the United States and authorized a new police force com-

\section{${ }^{75}$ Pierce, History of Chicago, Vol. II, pp. 435-37. ${ }^{76} \mathrm{John} \mathrm{P}$. Senning, "The Know-Nothing Movement in} Illinois, 1854-1856." Illinois State Historical Society Journal, Vol. VII (1914), pp. 17-23. 
prised only of native born citizens. They also raised the cost of beer licenses and enforced the sunday closing laws. The latter produced the Beer Riots in which the Germans, with considerable support from the Irish, fought against the forces of law and order. The majority of Chicagoans, however, were opposed to such restrictive measures; at the next election the Know-Nothings were defeated and most of the nativist inspired legislation was repealed. 77

The nativism of the fifties diminished during the Civil War years as the anti-foreign element turned its thoughts away from the Catholic menace to the more concrete danger of rebellion. The distinguished record of the Irish regiments in the war convinced many Chicagoans that the Irish indeed could be valuable citizens. However, a certain degree of anti-Irish sentiment survived, since many Irish were lukewarm toward the Union cause. 78

Anti-Irish sentiment continued to exist in Chicago during the post-Civil War period. As we have mentioned previously, Chicago society had become increasingly stratified toward the end of the century as frontier conditions passed away. In a certain sense the Irish Catholic popula-

77 F. 0. Bennett, Politics and Politicians in Chicago, pp. 97-100; John F. Flinn, History of the Chicago Police (Chicago: Police Book Fund, 1887), pp. 71-74; William Kirkland and Moses, History of Chicaso, Vol. I, pp. 130-31; "Our Irish," Chicago Tribune, April 19, 1874.

${ }^{78}$ Cook, Bygone Days in Chicago, pp. 6-12, 97 ; Sevina Pahorezki, The Social and Political Activities of William James Onahan (Washington, D. C.: Catholic University of America Press, 1942), pp. 18-23. 
tion had become more alienated from Protestant American society than ever before. By the $1880^{\prime} \mathrm{s}$ it was clear that the commercial and professional elite of Chicago was mainly Protestant American, while local politics was to a large extent the domain of the Irish. During the eighties the Irish had a significant control of the Democratic party and thereby exerted a powerful voice in the administration of municipal affairs. Having a rather practical view of politics, Irish machine politicians catered to the everyday needs of the community by giving party workers patronage jobs. The politicians also enriched themselves with bribes and kickbacks, and were intimately connected with gamblers and the saloon element. To civic-minded Protestants, many of whom were second and third generation New England Puritans, this kind of corrupt political system was anathema. They tried to counteract it by forming reform organizations like the Citizens Association and the Union League Club.79 To such individuals it appeared that the Irish were responsible to a great degree for the ills of urban society. Though they were sincere and to a large extent correct in blaming the Irish politicians for ruining city government, they often failed to distinguish between the sin and the sinner, so that at times it seemed they attacked a corrupt Irish politician more for his Irishness than his corruptness. For example, the Chicago Tribune, a staunch opponent of the

79Duncan, The Rise of Chicago, p. 146. For a history of the Union League Club see Bruce Grant, Fight for a City (Chicago: Rand lícNally and Co., 1955). 
Democratic machine seemed more concerned about the number of Irish aldermen than the corruption at city hall. 80

Although these reformers often engaged in nativist diatribes against the Irish, their main aim was to fight corruption and improve urban Iife, not to attack the Irish. Far different were the blatantly bigoted groups that gained popularity during the late eighties and early nineties. Their growth was triggered partly by the rise of Irish political influence and partly by the tremendous growth of the Catholic Church, most visible in the enormous expansion of the parochial school system. Moreover, although the HayMarket Riot of 1886 was followed almost immediately by a rise in anti-radicalism and anti-German sentiment and not by anti-Catholicism, nevertheless, it helped to stir up a general xenophobia that was eventually carried over to the Irish. But equally important as a cause of nativism during these years was the increasing alienation and dislocation of the "inbetweeners," as John Higham has termed them. This class included white collar workers, small business men and non-unionized workers who felt they were being squeezed out of a society dominated by giant industrial corporations, labor unions, and political machines. One of the few constant things they could cling to in this rapidly changing and rootless society was their American nationality. Thus as a means of asserting their own identity they attacked the foreign element, which seemed to pose a great threat to 
the future of a democratic Protestant America. 81 But perhaps they were more anti-Catholic than anti-foreign, since in many cities they joined forces with anti-Papist foreigners. For example, in Milwaukee German and American Protestants attacked Irish Catholics, while in Minneapolis Scandinavians were a significant element in anti-Catholic "native" American societies. In Chicago, however, the strongest allies of the native Americans were the Protestant Irish and British, whose traditional animosity against Irish Catholics was intensified during the eighties by Irish attempts to foment trouble between Great Britain and the United states. 82

There were several anti-Irish societies in Chicago during the late eighties. The most important was the United Order of Deputies, founded there in 1886. It expanded nationally and had at one time a total membership of between 10,000 and 15,000. There was also the American Protestant Association, established prior to the Civil War and dominated to a large extent by Orangemen from the British Isles and Canada. The American Protective Association, the foremost nativist society in late nineteenth century America, established branches in Illinois as early as 1888, but it did not become a significant force in Chicago until after

\section{${ }^{81} \mathrm{John}$ Higham, Strangers in the Land: Patterns of} American Nativism, 1860-1925 (Brunswick, New Jersey: Rutgers University Press, 1955), pp. 52, 59-60.

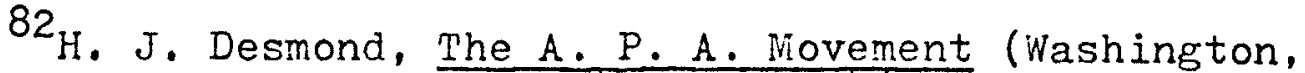
D. C.: New Century Press, 1912), pp. 45-46. 
1890.83

Chicago was also the home for a number of antiIrish newspapers. The most prominent was Slasson Thompson's America, which crusaded against Irish political influence and championed the cause of immigration restriction. There was also the Native Citizen and the Western British American, which often took pot shots at the Irish.

We must not, however, overemphasize the anti-Irish prejudice of this period. By and large, as Frank Condon would recall years later, there was a spirit of "live and let live" in Chicago. ${ }^{8}$ " If relations between Catholics and Protestants were often strained, they were also harmonious at times. For example, a number of liberal minded clergymen, both Protestant and Catholic, tried to promote a spirit of good will among men of all religions. Certainly, antiCatholic sentiment in Chicago during these years was in no way comparable to the nativism the Eastern Irish had to endure during the forties and fifties. Nevertheless, it did exist and played a part in molding a self-conscious Irish community.

$83_{\text {Higham, Strangers in the Land, p. } 61 \text {; Chicago }}$ Citizen, Jan. 5, Feb. 9, 1889, Oct. 4, 1890. For the A. P. A. movement see Donald I. Kinzer, An Episode in AntiCatholicism: The American Protective Association (Seattle: University of Washington Press, 1964).

${ }^{84}$ Duncan, The Rise of Chicago. pp. 24, 58-59; R.T. Berthoff, British Immigrants to Industrial America, 17901950 (Cambridge: Harvard University Press, 1953), p. 198.

85 Frank Condon to Philip Loeb, May 13, 1954, Frank Condon Papers, Chicago Historical Society. 
Irish ethnic identity in Chicago was thus maintained by their low economic status, the Catholic Church and other organizations, and anti-Irish prejudice. Such a community was as conducive to the flourishing of Irish nationalism as were the Irish ghettoes of Boston, New York, and Philadelphia. While Irish self-consciousness was strong, however. Irishmen also paradoxically felt a part of the nation and the city in which they were living, for they did not necessarily identify the concept of America or Chicago with the Protestant Establishment. Irishmen, for example, felt they were far more American than other immigrants. As one Chicago Irishman said some years later: "The're none of them foreigners when they come here, for their hearts and love were in America long before they thought of sailin' for America." 86 And the Irish also rapidly acquired Chicago's civic pride, a pride that had come about as a result of the tremendous expansion of the city, particularly after the disastrous fire of 1871. Irish nationalists in Chicago occasionally blasted their Eastern cousins for their haughtiness and presumption and pointed out that Chicago was the leading city for Irish nationalism.

In the years ahead as Irish self-consciousness would wane, it would mean more to be a Chicagoan than to be Irish; but the WASP's would also change their attitude toward Chi-

\footnotetext{
$86 \mathrm{~J}$. J. McKenna, Stories by the Original "Jawn" McKenna (Chicago, 1922), pp. 62-63.
} 
cago and the Irish, so much so that a man like Marshall Field IV, whose ancesters battled against corrupt Irish politicians, would become a loyal supporter of Mayor Richard Daley, perhaps the most successful of all Irish-American politicians. 


\section{THE DEVEIOPMENT OF IRISH-AMERICAN \\ NATIONALISM IN CHICAGO}

The revolutionary wing of modern Irish nationalism had its roots in the United Irishmen movement of the 1790's. Inspired by the radical revolutionary ideas emanating from France, the United Irishmen led by Wolfe Tone sought to establish a popular republic in Ireland. But these hopes were quickly crushed in 1798, with the dismal failure of a tardily and partially French-supported rebellion. British authorities, however, feared that in the future the Protestant Irish Parliament (semi-autonomous since 1782) might not be able to survive a more skillfully planned uprising. With this in mind they approached the Irish leaders on the feasibility of uniting the British and Irish legislatures and in 1800 persuaded a majority of them to accept this plan. Accordingly, the Parliament in College Green was abolished, and Irish representatives took their seats at Westminster. At the time it seemed like a wise solution to the Irish problem, but as events later proved, it was the beginning of the end for the hope of any real unity between the two islands.

During the negotiations for the Act of Union, British officials had convinced many Irish Catholic leaders, lay and clerical alike, that a united parliament would deal fairly with the question of Catholic representation. But 
the religious scruples of a mentally disturbed English king and the Tories' belief that Catholic Emancipation would undermine the Anglican establishment prevented the passage of a Catholic Relief Act for over a quarter of a century. This delay proved fatal to the interests of Union. In the meantime, Daniel $0^{\prime}$ Connell had skillfully used the issue of Catholic Emancipation to create a national movement to redress Irish grievances. During the $1820^{\prime} \mathrm{s}$, through means of the Catholic Association, he molded the people into a well disciplined political force and won a series of crucial elections, climaxing in his Clare victory in 1828. The Wellington Ministry, fearing further frustration of Irish demands would turn $0^{\prime}$ Connell's peaceful army into a violent one, granted Catholic Emancipation in 1829.1

During the next decade $0^{\prime}$ Connell sat in the House of Commons, working to ameliorate Irish problems through the British parliamentary system. But in 1840, despairing of finding any real solution to Irish grievances within the context of a United Kingdom, he established the National Repeal Association to dissolve the Union. Employing some of the same tactics he had used in the campaign for Catholic Emancipation, $0^{\prime}$ Connell tried to muster Irish public opinion

$1_{\text {For }} 0^{\prime}$ Connell and Catholic Emancipation see Sean - Faolain, King of the Beggars (Dublin: Allen Figgis Ltd., 1970); Michael Tierney (ed.), Daniel 0'Connell (Dublin: Browne and Nolan, 1949); James Reynolds, The Catholic Emancipation Crisis in Ireland, 1823-1829 (New Haven: Yale University Press, 1954); G. I. T. Machin, The Catholic Question in English Politics, 1820-1830 (London: Oxford University Press, 1964). 
behind Repeal. For several reasons the campaign got off to a slow start. But in 1843, it gained momentum. Huge crowds attended a series of monster meetings, in which $0^{\circ}$ Connell denounced the Union and predicted that by the end of the year England would surrender on Repeal as it did on Catholic Emancipation. Despite O'Connell's avowal of non-violence, these demonstrations seemed ominous to the British; they feared there might be a revolution. The movement came to a swift end, however, when British officials banned a mass meeting in Clontarf, and $0^{\prime}$ Connell cancelled it to avoid a bloody confrontation between his followers and English troops. After this the majority of Irishmen lost most of their enthusiasm for Repeal. 2

Although O'Connell laid the foundation for modern Irish nationalism, he was by no means a flaming radical. He admired the monarchy, customs, and language of England and was unconcerned about preserving the culture of Gaelic Ireland. A disciple of Bentham, he was chiefly interested in concrete reforms for the Irish people. In fact, he would have accepted the Union had he thought Ireland would receive fair treatment. Moreover, the Liberator failed in a large measure to win the peasants over to the cause of nationalism; he was not sufficiently concerned about agrarian reform, an issue far closer to the farmer's heart than

$2_{\text {For }} \mathrm{O}^{\prime}$ Connell and Repeal see Lawrence J. McCaffrey, Daniel $0^{\prime}$ Connell and the Repeal Year (Lexington: University of Kentucky Press, 1966); Kevin Nowlan, The Politics of Repeal (Toronto: University of Toronto Press, 1965). 
the somewhat abstract notion of Irish nationality. 3

In fighting for Repeal, $0^{\prime C}$ Connell received support from the Young Irelanders, a group whose ideas on the future of Ireland were quite different than his own. Through the pages of the Nation, individuals like Charles Gavan Duffy and Thomas Davis advocated Irish political independence. But unlike $0^{\prime C}$ Connell they also stressed the need to preserve the Gaelic culture of the country. Products of the Romantic Age, they despised the materialism of industrial England and were determined to prevent it from spreading to Ireland. Playing down the Catholic aspect of Irish grievances, they hoped to create an independent Ireland in which people of all religions -- Catholic, Protestant, and Dissenter -- and all classes -- landlord, shopkeeper, and peasant -- would live in harmony, united by a common historical heritage. But this was only a dream, for the division between Catholic and Protestant and between landlord and tenant farmer were as irreconcilable as the growing spirit of Irish nationalism was with British rule. And it was because of this noble illusion, the Young Irelanders (with the notable exception of individuals like John Mitchell) refused to campaign for land reform, a key issue which by tying the peasant to nationalism would have created a powerful movement. 4

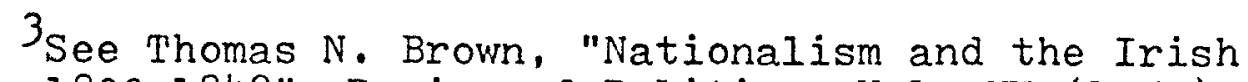
Peasant, 1800-1848", Review of Politics, Vol. XV (1953), pp. 435-39.

For Young Ireland see Charles Gavan Duffy, Young 
Although the alliance between $0^{\prime}$ Connell and Young Ireland was always uneasy, it managed to survive until 1846. In that year, however, the Young Irelanders withdrew from the Repeal Association when it passed a resolution absolutely ruling out violence to attain Irish independence. The following year they established the Irish Confederation in opposition to the Iiberator's organization. While the Young Irelanders had originally hoped to achieve their goals through non-violent means, the success of the French Revolution in 1848, inspired them to take up arms. Since they were hopelessly unprepared and lacked popular support the uprising was an utter disaster, ending in comic-opera failure near the bleak and miserable village of Ballingary, County Tipperary. But if the revolt fizzled out, the spirit of Young Ireland lived on and inspired in future generations the desire to see an independent Ireland.

Equally important for the future of Irish nationalism as Young Ireland was the Great Famine, which forced over one million emigrants to flee to North America. Living in the ghettoes of large cities, these exiles gradually lost their parochial attitudes and began to think of themselves as Irishmen, whose duty it was to avenge English injustice. 5 These immigrants and their children would play a major role in the revolutionary movements of the latter nineteenth cen-

Ireland (London: T. Fisher University Press, 1896); Denis Gwynn, Young Ireland and 1848 (Cork: Cork University Press, 1949).

5 Thomas N. Brown, Irish-American Nationalism, 18701890 (Philadelphia: Lippincott and Co., 1966), pp. 19-21. 
tury.

Though Irish-American nationalism became a potent force only after the Famine, there had been a current of Irish revolutionary sentiment in the United States since the beginning of the century. After the abortive rebellion of 1798, several United Irishmen fled to America where they served as a focus for the Anglophobia of other Irish immigrants. 6 Later on, during $0^{\prime C}$ onnell's crusade for Catholic Emancipation Irishmen in Boston, New York, and other cities organized societies to aid their countrymen at home.? Similarly, during the Repeal campaign several Irish-American groups collected money and voiced their hatred for the Union. In 1842, for example, the first national gathering of an Irish-American society, the National Repeal Convention, met in Philadelphia. 8

When Repeal failed in 1843, Irish-American nationalists began to lose interest in the Iiberator's campaign and turned instead to Young Ireland; by 1847, the majority of Irish nationalists in America supported Young Ireland. The futile uprising of 1848 dampened their enthusiasm for a while, but in the early fifties the revolutionary cause

${ }^{6}$ Carl wittke, The Irish in America (Baton Rouge: Louisiana State University Press, 1956), pp. 75-80.

7 George Potter, To the Golden Door (Boston: Iittle Brown, 1960), pp. 207-12.

${ }^{8}$ Oscar Handlin, Boston's Immigrants (2nd Ed; New York: Atheneum, 1969), pp. 152-53; Potter, To the Golden Door, pp. 388-402; Marcus Hansen, The Atlantic Nigration, 1607-1860 (New York: Harper and kow, 1961), pp. 168-69. 
picked up momentum again. With the outbreak of the Crimean War in 1854, Irish-Americans established the Civil and Military Republican Union to make England's misfortune Ireland's opportunity. This quickly gave way to two other groups, the Emmet Monument Association and the Irish Emigrant Aid Society. These organizations soon faded because of internal difficulties, but Irish-American nationalism was far from extinguished. 9

In 1858, Irish immigrants in New York founded the Fenians as an auxiliary to the recently established Irish Republican Brotherhood back home. The organization spread rapidly throughout the centers of Irish population, particularly among the Irish troops in the Union Army during the Civil War. When the war was over these soldiers anxiously looked forward to using their military training to strike a blow for Irish freedom. The Fenians, however, fell prey to the old Irish nemesis of factionalism. Disgusted with the inactive policy of President John O'Mahoney, the Senate wing under Colonel Roberts revolted from the parent body and conducted two abortive raids on Canada in 1866 and 1870 . Meanwhile, the movement in Ireland was greatly hampered with the arrest of several Fenian leaders in 1865. An uprising in 1867 met with dismal failure. Though the Fenians survived until the mid-eighties, they were almost totally mori-

9Handlin, Boston's Immigrants, pp. 153, 205-206; Potter, To the Golden Door, pp. 503-506, 570-72; William D'Arcy, The Fenian Movement in the United States, 18581886 (Washington: Catholic University of America, 1947), pp. 4-6; Wittke, the Irish in America, pp. 80-87; 151-52. 
bund after 1870.10 Instead, Irish-American revolutionaries turned to the Clan-na-Gael, the society that dominated Irish republicanism in the United States for the next fifty years and would still be in existence a century later when the age old Anglo-Irish conflict was renewed on the streets of Belfast and Derry.

The Clan-na-Gael was founded in New York in 1867 by a group of Irish-Americans disgusted with the factionalism of the Fenians. They believed the only way to renew the republican movement in the United States was to establish a new organization. Among its founders was Jerome Collins, scientific editor of the New York Herald. who later died on an expedition to the Arctic in 1880. ${ }^{11}$ Like the Fenians, the Clan was dedicated to "the attainment of the complete and absolute independence of Ireland by the overthrow of English domination by means of physical force."12 Unlike its predecessor, the Clan was a secret society, since Clansmen believed publicity had hurt the Fenians. ${ }^{13}$ Candidates for admission were forced to go through an exotic type

$10_{\text {For the Fenian movement see D'Arcy, The Fenian }}$ Movement in the United States; Brian Jenkins, Fenians and Anglo-American Relations During Reconstruction (Ithaca: Cornell University Press, 1969); T. W. Moody (ed.), The Fenian Movement (Cork: Mercier Press, 1968).

${ }^{11}$ John Devoy, "The Story of the Clan-na-gael," Gaelic-American, Nov. 29, 1924.

12 "Constitution of the United Brotherhood, 1877," reprinted in Special Commission Act, 1888: Reprint of the Shorthand Notes of the Speeches, Proceedines and Evidence Taken Before the Commissioners (London: H.M.S.O., 1890), Vol. IV, p. 493.

13 Brown, Irish-American Nationalism, p. 65. 
of masonic initiation ritual, and a cipher was used in official communication. The system was facetiously simple: letters of the alphabet were transposed so that the letter used actually meant the one preceeding it. Thus the members often referred to the Clan as the "V. C.." the cipher abbreviation for the United Brotherhood, its official name. 14

The Clan was made up of camps or clubs. Each had a number as well as a public name like the Napper Tandy Club or the Emmet Iiterary Society. This was supposed to act as a camouflage so outsiders would not know the true nature of the organization. Every camp had a senior and junior guardian responsible for its administration. The clubs in various states were divided into districts. These regions then elected delegates who, along with a chairman, secretary, and treasurer, made up the National Executive Committee. A Revolutionary Directory consisting of three members of the Clan and three from the Irish Republican Brotherhood was set up in 1877 , to co-ordinate activity on both sides of the Atlantic. 15

The Clan grew slowly at first but gradually gained strength during the early seventies, as members from the

14 Devoy, "The Story of the Clan-na-Gael," GaelicAmerican, Nov. 29, 1924; Thomas M. Beach, Twenty-Five Years in the Secret Service (London: Heinemann, 1892), pp. 107-15.

15 Devoy, "The Story of the Clan-na-Gael." GaelicAmerican, Nov. 29, Dec. 6, 1924; "Constitution of the United Brotherhood, 1877," Special Commission Act, 1888 , Vol. IV, p. 493; Beach, Twenty-ive Years, pp. 115-17. 
rival factions of the Fenians and political refugees from Ireland joined its ranks. By 1877, a decade after its establishment, it had about 11,000 members. 16

Though the Clan advocated the forceful overthrow of British rule in Ireland, members received little opportunity for armed action during the seventies. The society, however, was far from inactive. One of the main hopes of IrishAmerican revolutionaries was that Britain would become involved in a major war, providing Ireland with the opportunity to strike her blow for freedom. In 1876, it appeared that England might go to war with Russia over the Balkans. With this in mind, the Clan sent a delegation to the Russian minister in Washington to discuss the possibilities of some kind of Irish-Russian entente. The Russian evidenced little interest in the Clan's proposition; he claimed his government believed the Irish wanted only land reform and a limited measure of self-government, not total separation from Britain. Furthermore, any serious consideration the Russians might have given to the Irish faded when a rival group claimed the Clan did not speak for the Irish in America. At any rate, Russia and Great Britain patched up their differences in the Berlin Conference of 1878, and the expected war never occurred. 17

16 "Proceedings of the Ninth General Convention of the United Brotherhood," reprinted in Special Commission Act, 1888, Vol. IV, p. 568 .

17 Devoy, Recollections of An Irish Rebel (New York: Charles Young, I929), pp. 330, 399-400; Beach, Twenty-Five Years, pp. 140-42. 
Despite such setbacks the Clan continued to lay the groundwork for a revolution in Ireland. Members collected money and sent arms across the sea. They also raised funds for such projects as the building of a submarine to strike at the British navy. Though the submarine never benefited the Clan, the project was taken over by the United States Navy and eventually proved successful. ${ }^{18}$ A more fruitful venture was the plan to rescue Fenian prisoners from a British penal colony in Australia. In 1876, the Catalpa, a whaling ship, set out from New England for Freemantle, Australia and rescued six Fenians, but not without encountering a close call from the British Navy. 19

During the $1870^{\prime} \mathrm{s}$ the work of the Clan-na-Gael was one of preparation and not immediate war. This cautious policy was due in part to practical and realistic leaders like Doctor William Carroll of Philadelphia, a Donegal-born but American-reared Presbyterian, and John Devoy, an exFenian prisoner who arrived in the United States in 1871 , and was active in Irish-American affairs for the next fifty years. The premature and ill-prepared Fenian risings in Ireland and Canada were still vivid in their minds. They

18 See Richard K. Morris, John P. Holland, 1841-1914: Inventor of the Modern Submarine (Annapolis: U. S. Naval Institute, 1966); Beach, Twenty-Five Years, pp. 140-42; William 0'Brien and Desmond Ryan (eds.), Devoy's Post Bag, 1871-1928 (Dublin: C. J. Fallon, 1948-53), Vol. I, pp. 47071; Gaelic-American, June 16, 23, 30, 1923 .

19 For the Catalpa expedition see Sean O'Luing, Freemantle Mission (Tralee, Co. Kerry: Anvil Books, 1965); $\frac{\text { 2ep- }}{\text { (Tanian }}$ haniah Pease, The Catalpa Expedition (New Bedford, Mass.: G. S. Anthony, 1897). 
were determined the Clan would not become involved in such fiascos.

Geographically speaking, the Clan-na-Gael was a predominantly Eastern organization. The overwhelming majority of its members came from New York, New Jersey, Pennsylvania, and the New England States. 20 But there were camps scattered throughout the entire country. As early as 1873, there were local chapters in such unlikely places as Little Rock, Arkansas; Leavenworth, Kansas; and Salinis City, California. 21 It was in Chicago, however, that the Clan had its strongest center outside the Northeast. The Chicago Irish for a long time had been interested in the independence of their homeland. In 1842, Chicago had a branch of the Repeal Association. A decade later there was a flourishing chapter of the Emmet Monument Association and an auxiliary militia, the Emmet Guards. 22 The Irish in Chicago also gave considerable support to the Fenians. Their first national convention met in Chicago in 1863; the following year the city was the scene for the Fenian national fair. When the Fenians split, the overwhelming majority of the members in Chicago supported the

20 Based on the membership report in "Proceedings of the Ninth General Convention of the United Brotherhood," Special Commission Act, 1888, Vol. IV, p. 568.

${ }^{21}$ Clan-na-Gael Notebook, Devoy Papers, MSS 9824, National Iibrary of Ireland. oct. 20,1895 .

$$
22 \text { "Chicago's Irish Pioneers," Chicago Times-Herald, }
$$


more active Senate wing. They made plans to form an IrishAmerican navy to sweep British ships off the Great Lakes. Little came of this grandiose scheme. In the 1866 invasion of Canada, however, the Chicago revolutionaries did send about one thousand men and two vessels. They also contributed toward the abortive attempt in 1870.23

In Chicago, as throughout the nation, failure and factionalism destroyed the Fenians, and there, as elsewhere, the Clan-na-Gael began to fill the void. By early 1869, Clan organizers had established the first Chicago club, Camp 16, in the Bridgeport area. Others soon followed: in July, 1870, Camp 96 on the Near North Side; in August, 1870, Camp 99 in the Goose Island district, and early in 1871, Camp 117 in the Stock Yards area. Thus within four years after the Clan had been organized in New York it had clubs in most of the Irish districts of Chicago. 24 The Great Fire of 1871 hampered the society but it recuperated quickly and continued to grow throughout the $1870^{\prime} \mathrm{s}$.

Though the Clan in Chicago flourished during this decade, it produced few national leaders in Irish-American affairs. The only Chicagoan to attain national prominence during the seventies was the attorney, William J. Hynes. He, along with Doctor Carroll and Devoy, served until 1881

${ }^{23}$ Ruth M. Piper, "The Irish in Chicago," (M.A. Thesis: University of Chicago, 1933), pp. 18-27; W. J. Onahar, "Diaries of Wil.liam J, Onahan," Mid-America, Vol. III (1931), p. 163.

${ }^{24}$ Clan-na-Gael Notebook, Devoy Papers, MSS 9824, National Library of Ireland. 
as one of the three American members of the Revolutionary Directory. A County Clare native, reared in Springfield, Massachusetts, Hynes had as a youth been active in the Fenian movement. Before coming to Chicago in 1875, he served one term as United States Representative from Arkansas. $^{25}$

If Chicago played only a secondary role in IrishAmerican affairs during the seventies, the situation was quite different during the next decade. From 1881, until the Cronin murder in 1889, Chicago was easily the foremost center of Irish nationalism in the United States, producing several prominent figures. In fact, three of the major personalities in Irish-America during the eighties lived in the same neighborhood on the Near North Side.

The first of these was a youthful-looking and ambitious lawyer, Alexander Sullivan. Born in either Maine or Canada of County Cork parents (his father was a sergeant in the British army), Sullivan grew up chiefly in Amherstburg, Ontario. He moved to Detroit as a young man, becoming active in the Fenian movement and Republican politics. In 1867, he became involved in the first of several incidents that cast doubt upon his character. He was arrested for setting a fire in his own shoe store to collect insurance but was acquitted on the testimony of a young woman, Mar-

25 Charles Ffrench (ed.), Biographical History of the American Irish in Chicago (Chicago: Biographical PubIishing Co., 1897); Devoy, "Story of the Clan-na-Gael," Gaelic American, Dec, 20, 1924; Beach, Twenty-Five Years, p. 123. 
garet Buchanan, whom he later married in Chicago. Shortly after this incident Sullivan went to Santa Fe, New Mexico, where through his Republican connections he successively held the positions of Postmaster and Collector of Internal Revenue. His enemies claimed he lost both these positions for financial irregularities, and in view of his later record it is possible there was some truth to the charge. After leaving New Mexico in 1873, Sullivan arrived in Chicago and began working as a reporter on the Inter Ocean. Through the influence of Daniel O'Hara, a powerful Chicago politician, he was soon appointed as Clerk of the Board of Public Works. Meanwhile, he studied law and was admitted to the bar. In 1876, he got into trouble again when he shot and killed Francis Hanford, a school teacher who had accused Sullivan's wife of adultery. Hanford claimed Mrs. Sullivan tried to influence patronage in the school system by extending her feminine favors to certain politicians. Sullivan claimed he shot Hanford in selfdefense. He was tried twice. The first jury failed to reach a verdict; the second voted acquittal. This episode caused a good deal of anti-Catholic prejudice, and rumors floated around that Sheriff Frank Agnew, a member of the Clan-na-Gael, had fixed the jury. 26

${ }^{26}$ Background information on Sullivan based on Beach, Twenty-Five Years, pp. 61-66, 121; Devoy, "Story of the Clan-na-Gael," Gaelic-American, Dec. 27, 1924, Jan. 24, 1925: John T. McEnnis, The Clan-na-Gael and the Murder of Dr. Patrick Henry Cronin (Chicago: $\mathrm{r}^{\mathrm{H}}$.J. Schulte and J.W. Iiff, 1889), pp. 141-45; Chester C. Dodge, Reminiscences of a School haster (Chicago: R.F. Seymour, 194I); Chicago iri- 
Joining the Clan-na-Gael sometime during the midseventies, Sullivan moved up rapidly in rank. In 1879, he was elected a member of the National Executive Committee, representing the district of IIlinois, Ohio, and Indiana. 27 Thereafter his rise was spectacular. In 1881, he became Chairman of the Executive Committee and in 1883, President of the Irish National League of America. Though he gave up the latter position in 1884, and the former in 1885, he continued to have a powerful voice in Irish-American affairs until the Cronin murder in 1889.

A few doors away from Sullivan lived the man who was to become his arch enemy, Doctor Patrick Henry Cronin, an outgoing and popular bachelor. Born in Buttevant, County Cork in 1846, Cronin's family emigrated to America when he was an infant. They lived for a while in Baltimore and New York, but moved to St. Catherine's, Ontario when young Patrick was ten. There he attended the local Christian Brothers School and a private academy. In 1863, Cronin moved to Pennsylvania, working at odd jobs in several small towns. He went to St. Louis in 1868, took up the study of medicine and ten years later was granted a degree from the Missouri Medical College. Arter spending a year in Europe, he returned to St. Louis, becoming professor of medicine at

bune, Aug. 22, 1913; "The Case of Dr. Cronin," Federal Writers Project unpublished MSS, Illinois State Historical Library, pp. 3-29.

27 Devoy, "Story of the Clan-na-Gael," Gaelic American, Dec. 27, 1924. 
st. Louis College of Physicians and Surgeons. In November, 1882, he moved to Chicago and rapidly gained prominence in the Clan-na-Gael and other Irish societies. Though Sullivan had befriended him upon his arrival in Chicago and had secured a position for him at the Cook County Hospital, the two, as we shall see later, soon crossed swords and remained the bitterest of enemies until Cronin was murdered in 1889.28

Besides Cronin, another neighbor of Alex Sullivan was the British agent, Thomas Beach, known to his Irish "friends" as Doctor Henri Le Caron. Born in Colchester, Essex in 1841, Le Caron went to France as a young man. Staying there only a short time, he immigrated to the United States and upon the outbreak of the Civil War joined the Union Army under the name of Henri Le Caron. During his stay in the military he befriended several Fenians. Gaining their confidence by pretending he was a Frenchman sympathetic to the Irish cause, Le Caron learned a great deal about the Fenians' plans for the invasion of Canada. He informed his father about his discoveries, and his father told the English authorities. The British in turn contacted Le Caron and put him on the secret service payroll as an agent. He gave the English valuable information, particu-

${ }^{28} \mathrm{~A}$. T. Andreas, History of Chicaso (Chicago: A. T. Andreas Co., 1884-86), Vol. III, p. 530; Fienry in. Hunt, The Crime of the Century (Chicago: H.I. and D.H. Kockersperger, 1889), pp. 22-26; Beach, Twenty-Five Years, pp. 220-24; Chicago Citizen, Nov. 3, 1883, Jan. 19, 1884, April 26, I881; Diary of John Devoy, Devoy Papers, liss 9819, National Library of Ireland. 
larly on the 1870 Fenian invasion of Canada.

After the Fenian fiascos Le Caron studied medicine, earning extra money in his spare time by stealing bodies from cemeteries and selling them to medical schools. A few years later he moved to the small town of Braidwood, Illinois (about fifty miles southwest of Chicago) where he opened a pharmacy and began practicing medicine. In 1879 he organized a Clan-na-Gael camp in Braidwood with himself as Senior Guardian. In the early eighties he moved to the Near North Side of Chicago, but kept his pharmacy and connections in Braidwood, so he could continue to head his camp and be privy to the inner workings of the Clan-na-Gael. Throughout the eighties he sent the British government information on the Clan, the value of which is still in dispute. At any rate he played his part well; Chicago nationalists only learned his true identity when in early 1889, he took the stand as a prosecution witness in the Times-Parnell case. His disclosures had serious repercussions on the Irish nationalists in Chicago, where rival groups suspected one another of harboring British spies. 29

John Finerty was another prominent individual in Chicago Irish affairs during these years. Born in Galway in 1846, the son of the nationalist editor of the Galway

29 Background information on Le Caron based on his autobiography, Twenty Five Years; McEnnis, The Clan-na-Gael. pp. 113-15; Diary of John Devoy, Devoy Papers, MSS 9819. National Library of Ireland; Devoy, "Truth about Le Caron, Famous British Spy," Gaelic-American, Sept. 8, 1923; Martin Kaufman and Ieslie I. Hanawalt, "Body Snatching in the Midwest," Michigan History, Vol. IV (1971), pp. 31-32. 
Vindicator who died two years after he was born, Finerty was reared by an uncle. At the age of eleven he moved to County Tipperary. During the early sixties he engaged in nationalist activities to the point of having to emigrate to avoid prosecution. Arriving in the United States in 1864, he spent a few months in the Union army. The following winter he went to Chicago where he quickly became involved in the Fenian movement, taking an active part in the 1866 Canadian invasion. During the late sixties and seventies he worked for several Chicago newspapers, gaining a reputation as a distinguished reporter. In the late 1870's he covered certain Indian wars for the Chicago Times. Some years later he republished some of these articles as a book, War-Path and Bivouac, still useful to students of the American West. Pinerty was also an active politician, serving one term as United States Congressman from Illinois.

Although Finerty joined the Clan in the latter $1870^{\circ} \mathrm{s}$ and remained a member until his death in 1908, he never had much of an influence in the inner circles of the society. As we shall see later, he was far too much of a maverick for Chicago nationalists. Yet, because of his oratorical and journalistic abilities, he was a respected figure in Irish Chicago. Finerty, a flamboyant speaker, could whip up Irish Anglophobia, giving the English "hell" at rallies like the annual August 15 picnic of the United Irish Societies. He also wielded considerable influence through the pages of the Chicago Citizen, the newspaper he 
founded in 1882, and edited until his death in 1908. Week after week he advocated the most extreme form of nationalism, taking delight every time the British suffered humiliation, whether it be in Ireland, India, or Egypt. While it is difficult to determine the exact effect this newspaper had on the Irish in Chicago and the Midwest, there is no doubt it did its share to stir up the enthusiasm of the American Irish for the cause back home. 30

Individuals, then, such as Finerty, Sullivan, and Cronin gave direction to Irish affairs in Chicago during the 1880's. But the history of Irish-American nationalism involves more than the story of its leaders; it must also take-into account the factors responsible for the development of the movement.

When the immigrants of the famine years arrived in America they carried with them an intense hatred of England and a strong desire to avenge the misery they had left behind. These feelings were re-enforced in America where the poverty-stricken Irish had to endure the prejudice of AngloSaxon Protestants. Once away from Ireland the peasant was gradually transformed into a nationalist. In Ireland he had identified himself with his parish or at most his county. But in the United States where he was looked on as an Irish-

30 Background information on Finerty based on Ffrench, American Irish in Chicago, pp. 24-35; John J. Flinn, The Hand-Book of Chicaso Biography (Chicago, Standard Gurde Co., 1893), pp. 151-52; M. F. 5anning (ed.), The New liovement Convention (Chicago: By the Author, 1896), pp. 168-71. 
man by a hostile society and lived in ghettoes with his fellow countrymen, he gradually began to consider himself Irish, and the memories of local grievances were turned into national ones. 31

The famine immigrants passed on the sentiments of bitterness and revenge to their children, and it is this which largely accounts for the fierce nationalism in Chicago during the $1880^{\prime} \mathrm{s}$. Many of the most extreme revolutionaries had grown up in Irish ghettoes -- some in Chicago, others in the East and Canada -- and as youngsters had learned about the twisted justice of perfidious Albion. They heard of the English demons: Queen Iiz, so ugly she could not look at herself in a mirror, and Cromwell, delighting in the mangled corpses of Irish women and children. They were also told of more recent events like the cruel evictions and deliberate starvation of Irish peasants. They revered the Irish heroes: Henry Grattan, Daniel $0^{\prime C o n n e l l, ~ a n d ~ p a r-~}$ ticularly bold Robert Emmet, "the darlin" of Erin." Frank Lawler, United States Congressman from Chicago, expressed the sentiments of many an American-reared Irishman: "As an American who learned the story of Ireland from an Irish father and imbibed a hatred of tyranny, hence a love for. . . Irish nationality and Ireland from an Irish Celtic mother, I would be unworthy of being an American, a renegade to my

31 Brown, Irish-American Nationalism, pp. 19-21, 23. See also Michael Davitt, Speech Delivered by inichael Davitt in Defense of the Land League (London: Kegan, Paul, Trench, Trubner and Co., 1890), pp. 40-54. 
race. . If I did not.. . add my voice to that of the universal Irish race, 'Ireland a nation.".32 such sentiments acquired in childhood were not easily lost in the self-conscious Irish community in Chicago. Celtic Chicago could not forget its past.

Though interested in making Ireland a nation, IrishAmericans were equally concerned, perhaps more so, with humiliating proud Britania. In other words, for the Irish in the United States hatred of England was as important a factor behind their nationalism as Irish independence. Indeed, this is one of the reasons Irish-Americans supported the futile dynamite campaign; if it failed to liberate Ireland at least it made the British suffer. As John Finerty told Michael Davitt in 1886, the American Irish did not have to follow blindly the directions of their cousins at home, for they had their own score to settle with England, and settle it they would, with or without the approval of their countrymen across the sea. 33

The American-reared post-Famine generation were not the only Irishmen to passionately hate England. Many of the recent immigrants of the seventies and eighties had suffered from English oppression, real and imagined, and were quite vitriolic in their denunciation of the crown. But for many of those reared in Ireland, nationalist organizations like

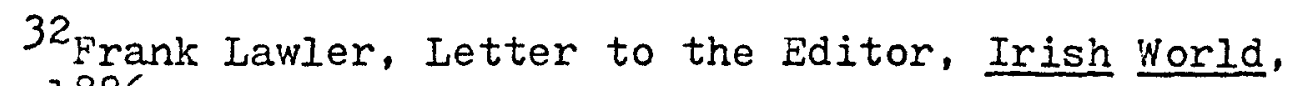
Jan. 30,1886 .

${ }^{33}$ Chicago Citizen, Aug. 21, 1886.
} 
the Clan-na-Gael served chiefly as social centers, where they could meet their own kind and re-create to some extent the atmosphere of life back home. 34 This factor was probably also important for a great number of Chicago narrowbacks (a second generation Irish-American) who had not grown up in the city and in a sense were as uprooted as the recent immigrants from Ireland. A large city could be as bewildering and lonely for a young Irish-American from the wilds of Michigan's Upper Penninsula, as it was for his cousins from Leitrim or Limerick. Besides this social function, the Clan also provided important connections useful in the advancement of one's career. As we shall see in the next chapter, this was particularly true in the case of politics.

Irish-American nationalism was also grounded in the Irish sense of inferiority and a concommitant desire for self-respect. Centuries of English domination and contempt for the Gaelic way of life had left the Irish people with a collective sense of inferiority. In Chicago this feeling had survived and had been perpetuated by their low economic and educational status. Paradoxically, it was among those who had attained some measure of success that this sense of inequality and desire for self-respect were most prevalent. For they had come into closer contact with Anglo-Saxons and thus were more aware of the low status of the Irish. To individuals seeking respectability the past was a heavy mill-

$$
{ }^{34} \text { See Brown, Irish-American Nationalism, pp. 19-23. }
$$


stone. Ireland had an almost unbroken record of defeat, and it was still submitting passively to English domination. In a nation like America, where self-government was the sign of a responsible people, Irishmen felt ashamed that Ireland did not control its own destiny. This they believed hurt their standing in the United States. 35 For example, John Finerty claimed that other ethnic groups were held in greater esteem than the Irish because "all other foreign elements in this country, with, perhaps, the exception of the Poles, have strong governments behind them, and they are held in more respect than the Irish who have no government of their own to boast of." 36 Matthew Brady, a Liverpool-born Irishman, expressed similar sentiments:

Shall the Irish remain slaves to a tyrant's arbitrary will in Ireland, or wandering over the earth, be the miserable subjects of the scurrillous jokes and insulting wit of ignoble, unmanly, brainless, monkey-like dudes, so poor in manhood, spirit and intelligence as to be unfit for higher uses than to keep the flies off us in summer time, -- shall we, I ask, remain thus miserably circumstanced from paltry, craven fear to make any sacrifice necessary to restore to us our plundered inheritance. 37

This sense of inferiority penetrated deeply into the minds of Irish-Americans. As a way of compensation they created their own racial myths. Irish orators harped on

$$
\begin{aligned}
& 35 \text { See Ibid., pp. 21-24. } \\
& 36 \text { Chicago Citizen, Feb. 8, } 1890 . \\
& 37_{\text {Ibid. , Oct. 10, } 1885 .}
\end{aligned}
$$


Young Ireland's theme of the uniqueness of Gaelic culture. They proclaimed that the Celts were a special people chosen by God "from among other nations and other races to achieve his own behests. "38 If the Irish still did not have their own government, at least they were not guilty of plundering other nations like the cruel and savage Saxon. And if England was economically more prosperous than Ireland, it was also materialistic and barbarian, lacking Ireland's spirit of Christian kindness and generosity.

The Celtic myth was extended to include the Irish in the United States. Irish-Americans felt they had made great contributions to their adopted country. As John Fitzgibbon, a Chicago businessman and frequent speaker at Irish rallies said, "We came to America to confer blessings upon the American people -- to civilize them, to teach them home love, to teach them that they ought to have more children than one or two (laughter and applause). We are a distinctive historical people, and we have done the American people a great deal of good by coming to this country." 39 Irish-American apologists also emphasized they had done much to defend and preserve the American way of life. They delved into records on the Revolutionary War, counting up the number of Irish soldiers to prove they had contributed to the struggle for American independence. It did not

${ }^{38}$ Rev. Maurice Dorney, cited Chicago Inter Ocean, June $24,1889$.

${ }^{39}$ Chicago Citizen, Aug. $24,1889$. 
seem to matter that most of the Irish troops. were of Scots origin and Protestants. Likewise, and with far more justification, they recounted the Irish contribution to the Union during the Civil War. And more recently, they reminded Americans that several Irish policemen had died in the Haymarket Square Riot to preserve the American system. IrishAmericans strongly condemned the tactics of the Chicago anarchists. While justifying the use of violence in the Irish struggle, they denounced it as a means of political or social change in the United States. In America, they argued, the injustices of society could be corrected through the ballot box. 40

Irish nationalists in Chicago constantly insisted on their loyalty toward America, emphasizing that their love of Ireland interfered in no way with their duties as American citizens. After all, they reminded Americans, Ireland only desired what the United States had achieved through violence over a century ago -- freedom from British rule. Indeed, to be a good American one had to sympathize with the Irish cause.

Besides the desire for self-respect, comradeship,

\section{${ }^{40} \mathrm{Cl}$ ipping from Ohio State Journal (Columbus), May} 28, 1886 in Scrapbook of American public Opinion Editorials from the Leading Papers of America on the Home Rule Bill for Ireland . . Presented to the Rt. Hon. William E. Gladstone from the Irish National League of America, Harrington Papers, MSS 9210, National Library of Ireland; also unidentified clippings in Scrapbook of American Public Opinion Editorials from the Leading Papers of America on the Home Rule Bill for Ireland. . Presented to Charles S. Parnell from the Irish National League of America, Harrington Papers, MSS 9211, National Library of Ireland. 
and vengeance, another factor contributing to Irish-American nationalism was the identity crisis of the second-generation Irish. Those born or reared in North America were obviously quite conscious of being Irish Catholics, distinct from other Americans. But within the Irish community itself, the Irish-born considered their American-reared cousins as narrowbacks, spurious Irishmen. The antagonism between the two groups usually stayed beneath the surface. (Most nonIrish-Americans and the Irish back home were oblivious to the divisions within the Irish-American community, for they usually Iumped all Irish-Americans together.) But at times the greenhorn's antipathy for the narrowback clearly manifested itself. In 1883, when Alexander Sullivan was elected President of the Irish National League of America, John Finerty bitterly complained that the American-born Irish were taking over control of Irish affairs in the United States. 41 A few years later, at the time of the Cronin murder, some of the dead doctor's enemies denounced his supporters as Americans, who had no business interfering in Irish matters. 42 (They conveniently forgot that sullivan and many of his cronies were not native Irishmen.) During the $1890^{\prime} \mathrm{s}$ a near schism resulted in the Catholic Church in Chicago, when a group of Irish-born priests opposed the appointment of an American Irishman as auxil-

\section{Diary of John Devoy, Devoy Papers, MSS 9819.} National Iibrary of Ireland.

$$
{ }^{42} \text { Chicaso Inter Ocean, July 14, } 1889 .
$$


iary bishop. 43 The antagonism of greenhorn for narrowback, however, should not be overemphasized. Nonetheless, it did contribute to the doubt many a second generation Irish-American had about his own identity. Therefore, as a means of asserting his Celtic origin, he became a nationalist.

Irish-American nationalism in Chicago thus sprang from several sources: the memory of British oppression. the desire for comradeship and personal advancement, the need for self-respect, and the identity crisis of the second generation. Nationalist sentiment was rooted in the Irish past, but it also met the psychological and practical needs of a people striving for acceptance as Americans. In other words, it was the product of both the immigrant's Irish background and his American experience. But because Irish-American nationalism was shaped so much by the American environment, this should not lead us to overemphasize the differences between it and its counterpart across the sea. Indeed, it was precisely because the Celtic-AngloSaxon conflict of the British Isles had been reproduced to some extent in cities like Chicago that Irish-American nationalism had developed into such a potent force. Feelings of revenge, the desire for self-respect, and problems of identity were not unique to Irish-America. They also existed in Ireland, albeit in different forms and degrees. Behind the chauvinistic utterances of many a Gaelic Leaguer

\section{3"Untold History of Catholic Chicago," Chicago} Daily News, Special Supplement, Dec., 1966. 
or Sinn Feiner, there was the same gnawing sense of inferiority and need for respect that could be found among the members of the Clan-na-Gael in Chicago. Even a man like Parnell, in so many ways a cultured Anglo-Saxon, felt throughout his life he was despised for being Irish. 44 similarly, the personal search for identity was responsible for much of the fierce nationalism among Irish leaders as among Irish-Americans. It is more than a coincidence that a highly disproportionate number of the leaders of the Easter Rising in 1916, and the subsequent War of Independence, were of mixed ethnic or religious origin. Individuals like Padraic Pearse, Tom Clarke, Eamon De Valera, Terrence MacSwiney, and Erskine Childers, to name only a few, were in some manner or other non-Irish. Somewhere along the line these individuals had to grapple with an identity problem like the American Irish; and they resolved it in like fashion.

Generally speaking. Irish-American nationalism had a beneficial effect on the Irish in Chicago. It tended to make them more tolerant and broad-minded in several respects. Since Irish nationalists emphasized that all inhabitants of Ireland, whether they be Catholic, Protestant, or Dissenter, were Irishmen, and since so many Irish leaders had been Protestants, nationalism helped to dispel the fear and animosity

$$
{ }^{44} \text { R. Barry } 0 . \text { Brien, The Life of Charles Stewart }
$$
Parnel1, 1846-1891 (London: Smith, Elder and Co., 1899), Vol. I, pp. 54-55. 
many Irish Catholics had for Protestants. At Home Rule rallies, for example, Catholics welcomed Protestant ministers and laymen speaking in defense of Irish self-government. An anonymous correspondent to the Chicago Citizen expressed the sentiments of many a Chicago Irish nationalist. After attending the annual August 15 picnic of the United Irish Societies he wrote: "It was indeed a happy sight to observe the Rev. Dr. Pepper, a Methodist minister, and the Rev. Father Hayes, a Catholic priest, standing on the same platform. 'Such a scene augurs well for the future of Ireland. 45

Irish nationalism also tended to make the American Irish more sympathetic toward the plight of other downtrodden people. John Finerty, for example, was an advocate of Polish independence. 46 Although Irish nationalist sentiment did not tame the anti-black prejudice of most IrishAmericans, it is noteworthy that several Irish nationalists were earnest supporters of Negro civil rights. John Boyle 0 'Reilly of Boston is one notable example, 47 but Chicago also had its champions. Alex Sullivan had been an advocate of equal rights for blacks since his days as a Republican in Michigan. In eulogizing Wendell Phillips shortly after his

45 "Observer, " Letter to the Editor, Chicago Citizen, Aug. 27, 1887.

${ }^{46}$ Chicaso Citizen, May $11,1889$.

47 See John R. Betts, "The Negro and the New England Conscience in the Days of John Boyle O'Rejlly," Journal of verro History, Vol. II (1966), pp. 246-61. 
death, Sullivan recalled that the old New England abolitionist "was one of the first men whose utterances aroused in my blood hatred of human slavery, and gave to my tongue some of its little power to denounce bondage even before I reached manhood." 48

Besides Irish freedom, the cause that most concerned Irish-American nationalists was that of the laboring man. This was not surprising since most of the Irish in Chicago came from a working class background. Nationalists were vehement defenders of labor's right to share in the wealth of the Gilded Age. Editorials in the Chicago Citizen constantly condemned monopolists and capitalists who overworked their employees and failed to pay them proper wages. Nationalists also often spoke at labor rallies. During the early part of 1886, Clansmen like Alex Sullivan and Richard Prendergast were prominent speakers at demonstrations of the Eight Hour Day movement. 49 Later in the year, the Labor Party rewarded Prendergast by endorsing him for County Judge. 50

In Chicago, however, there was never the intimate relationship between the Clan-na-Gael and the labor movement as in cities like Scranton, where Terrence Powderly,

48 Alexander Sullivan, Letter to the Editor, Irish World, Feb. 16,1884 .

${ }^{49}$ Chicago Tribune, April 11, 1886. See also Alexander Sullivan, Letter to the Editor, Irish World, Feb. 16, 1884.

${ }^{50}$ Chicago Citizen, Oct. 2, 1886. 
national leader of the Knights of Labor, was senior guardian of the local Clan-na-Gael camp. In Chicago prominent nationalists sympathized with the aspirations of the labor movement, but rarely were they, themselves, labor leaders. However, there were a few exceptions. Richard Powers, President of the Seaman's Union and an influential voice in the Chicago Federation of Organized Trades and Labor Unions, was a member of the Devoyite wing of the Clan-na-Gael and the Irish National League of America. 51 Elizabeth Rodgers was a more extraordinary example. Married and the mother of nine children, this Galway woman organized the first Working Women's Union of Chicago during the 1870's and in 1886, became Viaster Workman of District Twenty-Four of the Knights of Labor. She also found time to serve as President of the Eighth Ward branch of the Irish National Iand League of America. 52

If Chicago's Irish nationalists maintained friendly relations with the labor movement, they also managed to get along splendidly with church authorities. This was no mean achievement, since throughout most of the United States the Catholic Church was the inveterate foe of revolutionary Irish nationalism.

In America, as in Ireland, the Catholic Church for

${ }^{51}$ See the list of delegates of the Irish National League of America Convention, 1886, Chicago Citizen, Aug. $21,1886$.

52 Irish World, Dec. 18, 1886. 
some time had been opposed to secret Irish revolutionary societies. It contended the oath required by these groups interfered with one's duties to God and country, and that their revolutionary aims conflicted with the traditional teaching on a just war. 53 The Fenians, for example, met strong ecclesiastical opposition; Bishop Duggan of Chicago was one of their most vigorous critics. 54 Iikewise, during the $1880^{\circ} \mathrm{s}$ the Clan-na-Gael, as a secret extremist organization, was denounced by several members of the American hierarchy. Generally speaking, its most outspoken critics were the conservative bishops like Michael Corrigan of New York, Bernard McQuaid of Rochester, Richard Gilmour of Cleveland, and Francis Chatard of Indianapolis. Liberal prelates, on the other hand, were reluctant to interfere with the Clan and other secret societies. They feared such action would needlessly alienate many Irish Catholics from the Church. Among the leading advocates of this policy were Archbishop James Gibbons of Baltimore and Archbishop John Ireland of St. Paul. But perhaps the most vehement defender of the Clan-na-Gael and other Irish groups was Archbishop Feehan of Chicago. 55

53 For the background of the Church's attitude toward secret societies see Fergus MacDonald, The Catholic Church and the Secret Societies in the United States (New York: The United States Catholic historical Society, 1946), pp. 162 .

54 Devoy, Recollections, p. 119; John J. McGovern, "History of the Catholic uhurch in Chicago," Souvenir of the Silver Jubilee in the Episcopacy of His Grace the Most Rev. Patrick Augustine Feenan, Archbishop of Chicago (Chicago: n.p.. 1891), p. 201.

${ }^{55}$ See Robert D. Cross, The Emergence of Liberal 
When Feehan came to Chicago in 1880 , the Clan had been in existence a decade, and it was clear he had no intention of disturbing it. The Archbishop -- John Devoy described him as poor and weak 56 - hated controversy, and it was therefore natural he would not want to tangle with the Clan. Such a confrontation would have caused considerable turmoil in the diocese. But more importantly, Feehan was, himself, an advocate of Irish self-government, and although not a champion of violence, he did not believe in condemning those who thought otherwise. Perhaps, his background was partially responsible for this. Born and reared in Killenaule, County Tipperary, he grew up in a fairly nationalist area; Fenians like John O'Leary, Charles Kickham, James Stephens, and Joseph Denieffe came from the nearby towns of Tipperary, Mullinahone, and Kilkenny. And it was the North Riding of Tipperary that elected the Fenian O'Donovan Rossa to Parliament as early as 1869. Moreover, Feehan's clerical education was free from the ultra-conservative influences which crept into the Irish church after the arrival in 1849 of Archbishop Cullen, a close friend of the reactionary Pius IX. Feehan had attended Maynooth but had left in 1848; he was ordained in St. Louis four years later. Thus Feehan's education was quite different from that of the arch-conserva-

Catholicism in America (Cambridge: Harvard University Press, 1958), pp. 170-71; MacDonald, The Catholic Church and the Secret Societies, pp. 63-184.

${ }^{56}$ Diary of John Devoy, Devoy Papers, MSS 9819. National Library of Ireland. 
tive Archbishop Michael Corrigan of New York, one of the first students at the North American College in Rome. 57

Feehan was on friendly terms with several Irish nationalists, particularly Alex Sullivan, whose wife, Peg, was quite active in Catholic affairs. 58 sullivan was present at numerous dedications of schools and churches and occasionally invited the Archbishop to his home. 59 In 1887 , for example, Bishop McQuaid of Rochester bitterly complained that Feehan along with Michael Davitt had dined in Sullivan's home. McQuaid considered Sullivan a murderer because of the Hanford affair, and he regarded Davitt as a dangerous socialist. $^{60}$ Moreover, the Archbishop of Chicago contributed to certain non-violent projects of the Clan such as their burial plot in Mt. Olivet Cemetery and the fund to build a memorial to Charles Kickham. 61 Relations between the Clan

57 For the early life of Feehan see Cornelius J. Kirkfleet, The Life of Patrick Ausustine Feehan, Bishop of Nashvilie, First Archbishop of Chicaso, 1829-1902 (Chicago: Natre and Co., 1922), pp. 143-46.

58 Margaret Sullivan to James A. McMaster, May 16 , 1876. McMaster Papers, University of Notre Dame Archives; M. Sullivan to Fr. Daniel E. Hudson, Mar. 9, 1882, Hudson Papers, University of Notre Dame Archives; Fr. Edmund Hill to Fudson, Jan. 20, 1882, Huds on Papers; Diary of John Devoy, Devoy Papers, MSS 9819, National Library of Ireland.

${ }^{59}$ See Chicago Citizen, Jan. 3, 1885; Chicago Inter Ocean, May 20, 1889; Joseph J. Thompson, The Archdiocese of Chicaso (Des Plaines, III.: St. Mary's Training School Press, 1920), p. 397 .

60 picquaid to Corrigan, Feb. 1, 1887, Box C-16, Archdiocesan Archives of New York, Photostat Copy in University of Notre Dame Archives.

${ }^{61}$ Chicago Citizen, Nar. 19, 1887, oct. 15, 1887. 
and Feehan were so amicable that at a reception for the Archbishop, Henry Sheridan, a Clansman, boldly declared that when the time came for Ireland to take up arms he was confident Feehan would not withold his blessing. 62

On the national level Feehan also assisted the Clanna-Gael. In 1884, at the Third Plenary Council of Baltimore (when Feehan defended the Ancient Order of Hibernians) the American prelates decided that in the future a committee of archbishops should rule on the morality of secret societies. Since the majority of the archbishops were liberals, most suspected groups like the Ancient Order of Hibernians and the Knights of Labor were fairly safe. 63 The Clan-na-Gael, however, was in a more precarious position since it was a revolutionary as well as a secret society. During the latter $1880^{\prime}$ 's some conservatives wanted the archbishops' committee to denounce the Clan, but Feehan, Ireland, and Gibbons refused to do so. 64 Bishop McQuaid of kochester complained that these prelates wanted to be popular with Irishmen and, therefore, would take no action "to check anything wrong in an

$$
\begin{aligned}
& 62_{\text {Kirkfleet, Feehan, pp. } 143-46 .} \\
& 63_{\text {MicQuaid to Corrigan, Mar. } 15,25,1886, \text { Archdio- }}
\end{aligned}
$$
cesan Archives of New York. Photostat copy in University of Notre Dame Archives; HacDonald, The Catholic Church and the Secret Societies, pp. 109-14, 139; Kirkfleet, Feehan, pp. 234, 238-40; Zwierlein, The Iife and Letters of Bishop McQuaid (Rochester: The Art Print Shop, 1925-27), Vol. II, p. 336.

$$
64 \text { McQuaid to Corrigan, May 6, 1890, Nov. 29, } 1891 \text {, }
$$
Box C-15, Archdiocesan Archives of New York, Photostat copy University of Notre Dame Archives; 2 wierlein, McQuaid, Vol. II, pp. 378-85, 462; MacDonald, The Catholic Church and the Secret societies, p. $147,162-69$. 
Irishman. 65

Feehan's benevolent attitude toward Irish extremists permeated the entire archdiocese. Numerous priests were avid nationalists. The most notable of these was Father Maurice Dorney, pastor of St. Gabriel's parish in the stock Yards area. Dorney, a trusted friend of Sullivan, was quite influential in the inner circles of the Clan. He was also a powerful figure in the Stock Yards district, helping to solve many of the problems between labor and management. 66

Several other Catholic priests in Chicago were also members of the Clan-na-Gael. Catholic clergymen were always present at nationalist rallies. At the annual Emmet demonstration in 1895, when Sullivan made his first public appearance at an Irish gathering since the Cronin murder in 1889, there were at least twenty priests present as honored guests. In fact, Sullivan's enemies claimed the priests did more than merely attend Clan rallies. They maintained that several Catholic clerics had attempted to blacken the name of the dead Cronin and had used illegal means to secure the acquittal of one of his assassins. 67 There was also a charge

\section{McQuaid to Corrigan, May 6, 1890, Box C-15,} Archdiocesan Archives of New York, Photostat copy, University of Notre Dame Archives.

66 Ffrench, American Irish in Chicago, pp. 796-801; "Untold History of the Catholic Church,"; Charles J. Bushnell, The Sociel Problems at the Chicago Stock Yards (Chicago: University of Chicago Press, 1902), p. 44.

${ }^{67}$ Chicago Tribune, Mar. 5, 1895; Devoy, "Ford Decisively Defeated in irst Race Convention," GaelicAmerican, Sept. 29, 1923. 
that when some priests were sued for libel, Sullivan and his cronies fixed the jury to secure a favorable verdict. 68 The English-speaking Catholic newspaper in Chicago, the Western Catholic, was sympathetic to Irish revolutionaries and had little faith in parliamentary agitation. It contended an Irishman's motto "must be not agitate, agitate, agitate, but strike, strike, strike." Concerned that dynamite might needlessly take English lives, the Western Catholic suggested as an alternative that London be set ablaze, pointing out that recent fires had shown property could be destroyed without the loss of human life! 69

The relationship between the Clan and the Catholic Church, therefore, was radically different in Chicago than in eastern cities like Boston, New York, or Rochester. In these areas, where the church was more traditional, ecclesiastical authorities were decidedly hostile to extreme revolutionaries. Instead, they advised Irish-Americans to support Parnell and win Home Rule through peaceful means. Throughout the 1880's eastern priests were active in IrishAmerican constitutional movements, seeking to aid Parnell, while at the same time trying to combat the influence of the Clan-na-Gael.

In sharp contrast to the East, Chicago priests re-

${ }^{68}$ John Clifford to Archbishop James E. Quigley, Oct. 6, 1903, MSS 1/1903/Q/6, Archdiocesan Archives of Chicago. 1883. 69 Western Catholic, cited in Irish World, April 7, 
fused to lead a constitutional movement in opposition to the Clan-na-Gael. As a result, the influence of the conservative element in Chicago Irish affairs was almost nil. There were a small number of conservatives like $W$. P. Rend and William Onahan. They sometimes spoke at nationalist rallies but had little power in comparison to the Clan leaders. Had the Church in Chicago been opposed to the extremists, the situation might have been somewhat different. With the support of the Church the conservative element, as in other cities, might have made some attempt to rival the Clan. As it was, Chicago was completely Clan-na-Gael territory. 


\section{IRISH NATIONALISTS AND}

\section{AMERICAN POLITICS}

Since the early days of Chicago the Irish have played a major role in the fortunes of the Democratic party. In Chicago, as elsewhere, the Democrats' reputation as Anglophobes and the friends of immigrants attracted Irish voters. But the chief reason the Irish became ardent Democrats was economic. Arriving in the United States without skills and with little knowledge, they often had to work as laborers on public works projects which were either directly or indirectly connected with political patronage. Democrats were more than willing to give the Irish these jobs but in return expected their votes. The politicians struck a fairly good bargain; they found it relatively easy to organize the Irish into effective voting blocks, since the immigrants had been familiar with such tactics in Ireland. For several decades Irish tenant farmers had voted as their landlords directed, and more recently $0^{\prime}$ Connell had organized the people into a well-disciplined force to win Catholic Emancipation. Political bosses were not new to the Irish. ${ }^{1}$

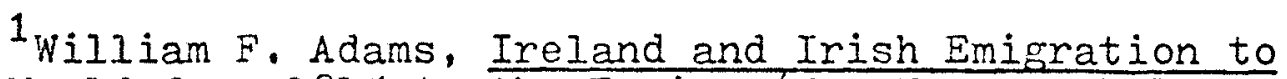
the New World from 1815 to the Famine New haven: Yale University Press, 1932), pp. 372-77; Ldward M. Levine, The Irish and Irish Politicians (Notre Dame: University of Notre Dame Press, 1966), pp. 36-37, 45, 112-13; Nathan Glazer and Daniel P. Moynihan, Beyond the fielting Pot (Cam- 
But the Irish supplied the Democrats with more than an army of voters -- they also provided leaders. Familiarity with the English language and Anglo-Saxon customs and a knack for organization gave the better educated Irishman a chance to rise in politics often denied to other newcomers. In the early years of Chicago the Irish contributed important politicians like Doctor William Egan and Thomas Hoyne. As the century progressed and the second generation matured, the Irish considerably increased their influence in the councils of the Democracy. By the 1880's they were by far the dominant element in the party of Jefferson and Jackson. In 1885. for example, fourteen out of eighteen members of the Democratic City Central Committee were Irish. 2

The Irish practiced a style of politics quite at variance with the middle class reformer's conception of government. Unlike the reformers, who believed that public officials should be primarily interested in promoting honest and efficient government, Irish bosses considered politics a business to be practiced for the personal gain of the politician. Many Irish aldermen in the City Council, for example, sold their votes to crooked entrepreneurs looking for franchises. Proprietors of gambling houses, saloons, and houses of prostitution had to pay off politicians to

bridge: Massachusetts Institute of Technology Press, 1963), pp. 224-26; George J. Fleming, "Canal at Chicago" (Ph. D. Dissertation, Catholic University of America, 1950), pp. $131,152-53$. 
avoid prosecution. Party workers gave jobs, food, and fuel to the poor but in return expected their votes. Elections were often a farce. Irish precinct captains, many of whom owned saloons, supplied free drinks on election day as an incentive to vote early and often; they also herded illegally naturalized immigrants and itinerants into voting booths or destroyed the ballots of opposition voters. It should be emphasized, of course, that corrupt machine politics was not an Irish monopoly -- the schemes of AngloSaxon bosses in Philadelphia and Pittsburgh were lucrative enough to make any conniving Irish politician envious -- but since it was one of the few means of advancement for ambitious Irish-Americans, they seemed to dominate it. 3

The chief Irish Democrat in Chicago during the 1880's was Mike McDonald, a gambler and proprietor of the Store, one of the most famous saloons in the city at that time. Born in Ireland, McDonald had come to the United States as

3 Levine, Irish Politicians, pp. 36-37, 47, 51, 10941; Glazer and Moynihan, Beyond the Melting Pot, pp. 22129: Carl Wittke, The Irish in America (Baton Rouge: Louisiana State University Press, 1956), pp. 103-13; George Potter, To the Golden Door (Boston: Little, Brown and Co., 1960), pp. 235-36; William V. Shannon, The American Irish (2nd ed., rev., New York: The Macmilian Co., 1966), pp. 6067; Joel Arthur Tarr, A Study in Boss Politics: William Lorimer of Chicaso (Urbana: University of Illinois Press, 1971), pp. 10-19, 65, 88; Iloyd Vendt and Herman Kogan, Bosses in Lusty Chicago (Bloomington: University of Indiana Press, 1967), pp. 9-96; M. R. Werner, Tammany Hall (New York: Doubleday, Doran and Co., 1928), pp. 62-53; Lincoln Steffens, The Shame of the Cities (New York: Hill and Wang, 1957), pp. 101-94. For Irish politicians in modern Chicago see Levine, Irish Politicians, pp. 143-202; Mike Royko, Boss: Richard J. Daley of Chicaso (New York: New American Library, 1971). 
a young man and had been involved in several shady ventures before arriving in Chicago around the time of the Civil War. Using his saloon and gambling business as a base of power, he gradually established himself as an influential Democratic politician. 4

Some commentators on the period have equated McDonald with Richard Croker, boss of Tammany Hall. This, however, is an exaggeration since politics was far less centralized in Chicago than in New York; no one man in Chicago had as much power as Croker. McDonald had to co-operate with several Democratic bosses, all of whom had a good deal of power in their own right. The most important of these were Aldermen Jimmy Appleton, John Colvin, Billy Whalen, and "Foxy Ed" Cullerton and gamblers Prince Hal Varnell and Sol Van Praag. McDonald and his Democratic gang got along fairly well together but they alone could not control Chicago politics. Although the city administration was usually in the hands of the Democrats during the 1880's, the city council usually had a Republican majority and several county offices were in Republican hands. The Democratic gang thus had to deal with a good number of Republican politicians. In fact several Republican aldermen were elected with the clandestine support of the boodle Democrats. Of course, deals between Democratic and Republican machine politicians were quite common in late nineteenth century urban America. In the realm 
of local politics party labels meant little; the spoils of office were far more important. 5

The Democratic gang also needed a friendly mayor for patronage purposes and to insure city agencies and departments would not upset the intricate system of graft. The boodlers found such a man in Carter H. Harrison, the Democratic mayor of Chicago during most of the 1880's. Although a native Protestant American, Harrison did not think like a middle class reformer. Born and reared in Kentucky, he did not share the New England Puritan heritage of most Protestant Americans in the city. Besides he spent a few years in Paris where he picked up certain continental attitudes toward Iife. He saw nothing wrong in moderate gambling or drinking and firmly believed that all the laws in the world would not wipe out the evil of prostitution. Harrison was thus temperamentally equipped to wheel and deal with the gang. But though he conspired with the boodlers, he was by no means their puppet. He cut down on some of their more serious abuses, and is generally considered to be one of the better mayors of the Gilded Age. Democratic politicians had to compromise with him because he was a popular vote getter appealing to several different groups within the city. Irish-Americans, for example, liked his sympathetic atti-

5 Wendt and Kogan, Bosses in Lusty Chicago, pp. 9110; Tarr, Boss Politics, pp. 17, 31-32; C. O. Johns on, Carter Henry Harrison I (Chicago: University of Chicago Press, 1928), pp. 138-40; Carter H. Harrison II, Growing up with Chicago (Chicago: Ralph Fletcher Seymour, 1944), pp. 228, 261. 
tude toward Irish self-government. Harrison was often present at Irish rallies, spoke in defense of Irish freedom in Dublin in 1882, and always supported pro-Irish resolutions in the city council. 6

Thus, Chicago politics during the 1880's was not controlled by a neatly centralized political machine like New York's Tammany Hall. Mike McDonald might be a powerful boss but he had to share his control with several other influential Democrats. And Democratic politicians in turn had to deal with boodle Republicans and Mayor Harrison. Arrayed against this combination were the middle class reformers, but until the late nineties they met with little success in combating this system of corrupt politics.

It was in this political labyrinth that the Clan-naGael operated. Unfortunately the lack of private papers and the complex nature of Chicago politics during the period prevent us from knowing all the detailed maneuvering of the Clan politicians. Nonetheless, memoirs and newspaper accounts provide sufficient information to establish the general role the Clan played in Chicago politics. First of all, almost every prominent member of the Clan-na-Gael (excluding the minor Croninite faction which split from the main group in 1885) was deeply involved in

${ }^{6}$ Johnson, Harrison I, pp. 3 ff: Willis J. Abbot, Carter Henry Harrison: A Nemoir (New York: Dodd, Nead and Co., 1895), pp. 112, 122-24; Harrison II, Growing Up With Chicago, pp. 253-59; Paul H. Douglas, "Introduction," Wendt and Kogan, Bosses in Lusty Chicaso, p. xi; Irish World, April 9, 1887 . 
the machine politics of Chicago, though most Irish politicians were not Clansmen. The overwhelming majority of Clanna-Gael politicians were Democrats but there were a few prominent Republicans. These Republicans, however, were of the boodle, not the reform, variety. Clan members often acted together in the wheeling and dealing of city politics, sometimes irrespective of party lines. At times outside forces would pull members in opposite directions and they would take different positions. But despite occasional differences, Clansmen always remained friendly with one another and helped each other whenever the circumstances permitted.?

Secondly, the Clan-na-Gael, either by throwing its support behind a particular politician or by having its members in influential positions in both the Democratic and Republican parties, became a political machine supplying its rank and file with plenty of jobs. ${ }^{8}$ During the 1890's Finley Peter Dunne poked fun at this aspect of the Clan. Mr. Dooley, after returning from a meeting of his local Clan-na-Gael camp, explained:

7 Based on an examination of the Chicago Tribune, Chicaso Inter Ocean, Chicago Times, and the Chicaso Citizen, and biographies of Irish nationalists found chiefly in Charles Ffrench (ed.), Biographical History of the American Irish in Chicaso (Chicago: American Biofraphical Publishing Co., 1897); and it. P. Fanning (ed.), The ilew Movement Convention (Chicago: By the Author, 1896).

${ }^{8}$ See Diary of John Devoy, Devoy Papers, MSS 9819 , National Library of Ireland; Devoy, "Story of the Clan-naGael," Gaelic-American, Jan. 10, Feb. 28, 1925; Chicago Inter Ocean, Aug. 17, 1889. 
I was down at a meetin' iv th' Hugh o'Neills, [a Clan camp] an' a most intherestin' meetin' it was, Jawn. I'd been niglictful iv me jooty to th' cause iv late, an' I was surprised an' shocked to hear how poor ol' Ireland was sufferin'. Th ' rayport fr'm th' Twinty-third Wa-ard, which is in the County Mayo, showed that th' sthreet clanin' conthract had been give to a swede . . . I felt dam lonely, an' with raison too; f'r I was th' only man in th' camp that didn't have a job. An' says $I$, 'Gintlemen,' says I, 'can't I do something f'r Ireland, too?' I says. 'I'd make a gr-reat city threasurer,' says I, 'if ye've th' job handy,' I says; and at that they give me th' laugh, and we tuk up a subscription an adjourned.9

The unofficial leader of the Clan-na-Gael machine was Alexander Sullivan. Sullivan, as we have mentioned previously, had been active in Republican politics in Nichigan during the late $1860^{\circ} \mathrm{s}$. In 1872, however, he left the Republican party, believing it had dragged its feet in restoring home rule to the South, and supported Horace Greeley, the Democratic and Liberal Republican candidate for President. But his decision to leave the Republicans was strengthened by events in Chicago. When he arrived there in 1873, the city was undergoing somewhat of a political revolution. The non-partisan "Pire-Proof" administration of Joseph Nedill, in power since 1871, was cracking down on the enforcement of the Sunday liquor laws, much to the disgust of Germans, Irish, and liberal-minded Americans. In

9 Finley Peter Dunne, Mr. Dooley: In the Hearts of His Countrumen (Boston: Small, haynard and Co., 1899), pp. $42-43$. 
order to ensure the defeat of a similar administration in 1873, "personal liberty" Republicans, as they were called, joined Democrats to form the People's Party. The People's Party won the election, and Daniel O'Hara, successful candidate for City Treasurer used his influence to have SulIivan, who had supported the new party, appointed as Clerk in the Board of Public Works Office. The People's Party gradually faded back into the Democrats, and many Irish and German Republicans went along. Sullivan was one of these; he remained a Democrat until 1884 when, as we shall see later, national politics induced him to return to the Republican fold. 10

Although Sullivan never held any public office after the Hanford murder -- he was too unpopular with the nonIrish population -- he wielded tremendous power in Chicago politics because of his position as leader of the Clan-naGael. He made deals with politicians promising them the support of the Clan in return for patronage. And the patronage at his disposal made him popular among the Irish. In the early 1880's, for example, he backed Mayor Harrison and

10 Thomas M. Beach, Twenty-Five Years in the secret Service (London: Heinemann, 1892), pp. 61-66, 121; Devoy, "Story of the Clan-na-Gael," Gaelic-American, Dec. 27, 1924, Jan. 24, 1925; John T. McEnnis, The Clan-na-Gael and the Murder of Dr. Patrick Henry Cronin (Chicago: F. J. Schulte and J.W. Iliff, 1889), pp. 141-45; Chicago Tribune, Aug. 22, 1913; M. L. Ahern, the Great Revolution: A History of the Rise and Progress of the People's Party in the City of Chicago and County of Cook (Chicago: Lakeside Publishing and Printing Co., 1874); A. J. Townsend, "The Germans in Chicago," (Ph. D. Dissertation, University of Chicago, 1927), pp. 57-61. 
in return was permitted to appoint several men to the police department. ${ }^{11}$ He also secured positions for Clan members in several other city and county departments. His brother, Florence, was a clerk in the Superior Court of Cook County, and two of his closest cronies, Timothy Crean and Larry Buckley (both Democrats) also had soft political jobs. ${ }^{12}$ sullivan also exerted a great deal of influence through his close friendship with Alfred S. Trude, a criminal and labor lawyer, and one of the most powerful Democratic barons in the city. In 1895 Devoy wrote:

The majority of the Irish in Chicago hate Sullivan, but allow themselves to be dominated by a band of five or six hundred unprincipled politicians who are a disgrace to them -- "toughs," ward "heelers," gamblers, liquor dealers and thugs, all of whom would leave him to-morrow if he was "thrun down" as a politician, as he would be if Trude, the Englishman and champion juryfixer withdrew the support that has sustained him for ten years. Some

${ }^{11}$ Devoy, "Story of the Clan-na-Gael," Gaelic-American, Jan. 10, 1925; Chicago Inter Ocean, May 26, Aug. 31 , Sept. 3. Dec. 17, 18, 1889. Sullivan tried to make a deal with Harrison's son, Carter Harrison II, in 1897 when the young man was making his first bid for the mayor's office. In return for the support of Camp 20 of the Clan-na-Gael, Sullivan wanted Harrison, if elected, to discharge two police officials connected with the investigation of the Cronin murder and to permit him to appoint some city officials. Harrison, wary of becoming involved with Sullivan, declined the offer. Harrison II, Growing Up With Chicago, pp. 283-84; Harrison II, Stormy Years: The Autobiography of Carter $\mathrm{H}$. Harrison (Indianapolis: Bobbs-Nerrill Co., pp. $106-107$.

${ }^{12}$ Chicago Tribune, oct. 7, 1884; Chicago Citizen, Sept. 4, 1886; Devoy, "Clan-na-Gael Convention in Boston Split the Organization," Gaelic American, Nov. 10, 1923; Fanning, The New Movement Convention, p. 204. 
time the secret of that support

will come out -- when it is too

late to be of any use.13

Sullivan and the Clan-na-Gael were certainly not as dependent on Trude as Devoy would have us believe. Several Clansmen held influential positions in both parties and always had a good deal of patronage at their disposal. One of the most important of these was Daniel Corkery, a rich coal merchant. Born in Chicago of County Cork parentage, Corkery was Senior Guardian of Camp 41 in the Bridgeport area and also served as the Illinois delegate on the National Executive Committee of the Irish National League of America. He was one of the most powerful Democrats in the city; several members of his camp held political positions. James $C$. Strain served as clerk in the County Commissioners office and as warden of the County Hospital; Michael J. Bransfield was Assistant City Treasurer during the Crieger administration (1889-91); and John Powers and Edward P. Burke)were aldermen on the city councir. 14

Two other important Democratic Clansmen were Francis Agnew and Michael McInerney. Agnew, a wealthy building contractor of Scottish birth but Irish parentage, was a member of Camp 20 and an influential magnate in local politics. At one time or another he had been Sheriff of cook

${ }^{13}$ Diary of John Devoy, Devoy Papers, MSS 9820, National Library of Ireland.

14 Chicago Inter Ocean, July 14, 1889, Chicago Citizen, Jan. 4, 1890; Ffrench, American Irish in Chicago, pp. 426, 429; Wendt and Kogan, Bosses in Lusty Chicago, p. 38; Harrison II, Stormy Years, p. 193. 
County and Chairman of the Cook County Democratic Central Committee. McInerney, a Limerick man with the distinction of having the largest undertaking establishment in Chicago, was the Democratic boss of the Stock Yards district and a close friend of Father Maurice Dorney. ${ }^{15}$

There were also high ranking Republican Clansmen. The most prominent of these was John M. Smyth. B Born off the coast of Newfoundland as his parents were emigrating from Ireland, Smyth grew up in Chicago and established one of the largest furniture businesses in the city. A mogul in machine politics, Smyth controlled Republican affairs in several wards on the Near West Side and served for a while as alderman and Chairman of the Cook County Central Republican Committee. During the 1890's he was the ally of the Republican boss, William Lorimer. Though newspapers refused to criticize him for fear of losing his advertisements, reform-minded Republicans hated him. Walter I. Fisher called him one of the "most dangerous and demoralizing political influences" in the community. But if middle class reformers distrusted him, Smyth was a great favorite with the Clan-na-Gael. Devoy singled him out as one of the largest dispensers of patronage for Clan members. 16

${ }^{15}$ Chicago Citizen, Sept. 13, Oct. 25, 1890; Chicago Inter Ocean. July 14, 1889; Devoy, "Story of the Clan-naGael," Gaelic-American, Jan. 10, 1925; Harrison, Stormy Years, p. 86, F'rench, American Irish in Chicago, pp. 56874: Fanning, The New Movement Convention, pp. $266,268$. 16 Ffrench, The American Irish in Chicago, pp. 1015: Harrison, Growing up with Chicago, pp. 209-11, Tarr, Boss Politics, pp. 34, 43, 55, 59,76-77, 98 . 
Therefore, with Corkery, Agnew, McInerney, Smyth, and several others ${ }^{17}$ in influential positions, the Clan-naGael under Sullivan's leadership became a well-oiled political machine, helping to elect Clan members and supplying the rank and file with jobs. The question arises as to whether the Clan in Chicago was a truly Irish nationalist organization or simply a political tool. The answer lies somewhere in between. There were undoubtedly some rank and file members who joined the Clan to get jobs. This is particularly true in the case of those Irish who did not grow up in Chicago and lacked the all important neighborhood connections. There are several examples of Irish immigrants and IrishAmericans reared outside of Chicago who quickly secured employment through their nationalist affiliations. ${ }^{18}$ Moreover, some politicians became Clan members simply for political reasons. Certainly Johnny Powers, alderman from the Nineteenth Ward, had only a passing interest in the Irish

17 other influential Clansmen in politics include Judge Richard Prendergast (until he broke with Sullivan in the late $\left.1880^{\circ} \mathrm{s}\right)$; Judge Thomas Moran; Michael Ryan, County Clerk; Austin Doyle, Chief of Police; John F. Beggs and Matthew P. Brady, leaders of the Irish-American Republican club of Cook County; John F. Finerty (after his reconciliation with Sullivan), Oil Inspector during the Roche Administration (1887-89); and Lawrence McGann, Commissioner of Public Works and Congressman during the $1890^{\prime} \mathrm{s}$. Sullivan to Devoy, Oct. 19, 1882, William O Brien and Desmond Ryan (eds.), Devoy's Post Bag, 1871-1928 (Dublins C. J. Fallon, 1948-53). Vol. II, pp. 154-55, United States, Biographical Directory of the American Congress 1774-1961 (Washington: Government Printing Office, 1962), pp. 1297-98; Chicago Inter Ocean, June 3, Dec. 17, 1889; Chicago Tribune, Dec. 17. 1889, Chicago Citizen, Sept. 11, 1886 .

${ }^{18}$ See Chicago Tribune, Dec. 11, 1889, Jan. 11, 1894; Chicago Inter Ocean, May 26 , July 31, Dec. 17, 1889. 
cause. But most of the leading Clan politicians were deeply concerned about Ireland. Even John Devoy, who opposed the Sullivan-dominated Clan, admitted that men like Smyth and Corkery sincerely loved Ireland. ${ }^{19}$ While these men worked for an independent Ireland, they were also Americans and Chicagoans anxious to get ahead in life like their fellow citizens. Thus it was not surprising that they used their nationalist connections to further their quest for power. AIthough dreamers on the Irish question, they were realists in the realm of American politics.

There was, however, a group of nationalist-minded Irish-Americans which detested the Sullivan-run Clan-naGael. Some hated Sullivan primarily for his dictatorial policies in Irish affairs, others because he had tainted Irish nationalism with corrupt machine politics. It was a loosely defined group. Some were Democrats like William J. Hynes and Patrick W. Dunne, father of the future governor of Illinois. The political careers of both these Irishmen. were cut short after they ran afoul of Sullivan in the early 1880's. Others were Republicans like John F. Scanlan and Patrick McGarry or labor leaders like Richard Powers and Daniel Gleason. As the decade progressed their numbers grew slightly; they received a good deal of encouragement in 1885 when Doctor Patrick Cronin Ied a group of Irish nationalists out of the Clan-na-Gael.

${ }^{19}$ Devoy, "Story of the Clan-na-Gael," Gaelic-American, Jan. 10, 1925. 
These individuals did not always act in unison in political matters. In presidential campaigns, for example, Republicans and Democrats went their separate ways. But they had one common goal -- to undermine Sullivan's influence in local politics and end the connection between Irish nationalism and machine politics. Generally speaking it was a loosing battle since Sullivan had tremendous power with the local politicians as well as the support of most Irish-Americans in Chicago. Occasionally, however, they met with success. The most notable example of this occurred in 1882 when John Finerty was elected to Congress.

In the autumn of 1882 the two leading candidates for United States Representative from the heavily Irish Second Congressional District in Illinois were John F. Finerty and Henry F. Sheridan, both members of the Clan-na-Gael. Finerty, however, for almost a year had been at odds with the Clan leadership over Irish matters. The Clan, therefore, threw its support to Sheridan, a loyal follower of Sullivan and alderman from the Fifth Ward. With the backing of the Clan and a majority of other machine politicians, Sheridan received the Democratic nomination. 20

Although Finerty lost the nomination several Irish Democrats like John Comiskey and labor leaders and Republicans like Richard Powers, Daniel Gleason, and John F. Scanlan urged him to run as an independent Democrat. Fin15. 1882 .

$$
{ }^{20} \text { Chicago Tribune, Sept. 15, 16, 19, 28, oct. 13, }
$$


erty's supporters believed that the fiery journalist and orator would be a far superior representative of the Irish people in Congress than a politican hack like Sheridan. These individuals launched a Finerty movement, circulated petitions, and on October 9, saw the colorful Galwayman announce his candidacy for Congress before a cheering crowd of 1,200 Irishmen. 21

Finerty waged a strong campaign. Though he did not personally attack Sheridan, he continually denounced boss politics, proudly proclaiming that he would be an Irish rebel whether he was fighting the English or corrupt politicians. He advocated building up the American Navy so the United States would no longer have to cow-tow to the British on the high seas. With a strong navy, Finerty asserted, we would be able to demand that Britain turn over American citizens rotting away in English jails. He also advocated a high tariff to protect American industry and labor from British competition. Sheridan's main charge during the campaign was that Finerty considered himself too grand to live in the district he was running in. 22

Orthodox Clan-na-Gael members were clearly concerned about Finerty's threat to their candidate. 23 Independent

\section{${ }^{21}$ Chicago Tribune, Oct. $8,9,10,1882$.}

22 Chicago Tribune, oct. 10, 14, 15, 17, 18, 20, 25, 26, 29, Nov. 4, 5,6,7, 1882; Chicago Times, oct. 27, 28, 29. Nov. 1, 7, 1882 .

${ }^{23}$ Chicago Tribune, Oct. 9, 1882; Sullivan to Devoy, 0ct. 9, 1882, Devoy's Post Bag, II, 154-55. 
Democrats and Republicans, attracted by Finerty's flamboyant personality and his denunciation of boss politics, were flocking into his camp. But what worried Sheridan's supporters even more was that the machine politicians were beginning to fight among themselves.

The problem centered around William McGarigle, Democratic candidate for Sheriff of Cook County. McGarigle, who later had to flee to Canada to avoid prosecution for embezzlement of public funds, received the nomination through the influence of Mike McDonald, Edward Cullerton, Charles Hildreth and several other boss politicians. The son of an Irish Protestant, McGarigle had a reputation for being an anti-Catholic bigot, despite the fact that he and his Irish Catholic followers denied it. Because of his reputation, most members of the Clan-na-Gael hated him and had opposed his candidacy at the nominating convention. Although the Clansmen did not run a candidate in opposition to McGarigle after he had received the nomination, they were less than enthusiastic in their support. Many, presumably, were willing to trade off McGarigle in return for Republican votes for Sheridan, and two other Clansmen running that year, Richard Prendergast, Democratic candidate for County Judge, and Michael Ryan, Democratic candidate for County Clerk. In fact, in Sheridan's home ward, the Fifth, there was open revolt against the machine, despite the alderman's public endorsement of McGarigle. 24

${ }^{24}$ Chicago Tribune, Sept. 24, oct. $8,11,12,13,15$, 
Considering the attitude of Clan Democrats toward McGarigle, McDonald, Cullerton and their gang were in no mood to exert themselves for Sheridan. This became increasingly clear in the last two weeks of the campaign. Sheridan's followers declared that several Democratic politicians were not giving sufficient support to Sheridan's candidacy, and rumors floated around that some of them were trading of $f$ Sheridan to get extra votes for McGarigle and others. At any rate either through deals or the apathy of McDonaldCullerton forces for Sheridan, Finerty won the election by a substantial margin. 25 Finerty had beaten the Clan politicians, but only because of internal divisions existing in the Democratic machine.

Finerty made an energetic Congressman, though most of his actions were either directly or indirectly concerned with the Irish cause; Whitelaw Reid, editor of the New York Tribune, for example, characterized him as "the member from Illinois elected to represent Ireland in the Congress of the United States." 26 ,Finerty introduced a bill to strengthen the Navy, contending that American naval power was totally inadequate to meet the needs of the modern world. Eventually, of course, he hoped the United States would be strong enough to challenge British maritime supremacy and liberate Ireland. 27 Similarly, he voted against the Morri-

25 Chicago Tribune, Nov. 9, 1882; Chicago Times, oct. $28,29,30$, Nov. $2,8,9,1882$. ${ }^{26}$ Cited in Chicago Citizen, Dec. 15, 1883. 27 Chicago Citizen, Feb. 9, Mar. 8, 1884. 
son Bill lowering the tariff, because he believed it would make America the dumping ground for British manufacturers. 28 Finerty also took his campaign against the British outside the halls of Congress. When the English were going to execute Patrick O'Donnell for killing James Carey, the informer in the Phoenix Park murders, Finerty and a delegation of Irish-Americans went to President Arthur to ask him to intercede to save $0^{\prime}$ Donnell's life. The administration, however, did little, and when O'Donnell was hanged, Finerty in characteristic style blasted Arthur and "feeble" Frelinghuysen, the secretary of State. He demanded the recall of James Russell Lowell, the American Minister in London, describing him as a "weak snob and Duke of Dudes."29

Finerty apparently liked life as a Congressman; in 1884 he decided to run for another term. There was some speculation that he would get the official nod of the machine. After all he was a Democrat, albeit an independent one, and popular with the Irish in the district. Besides Mayor Carter Harrison, Democratic candidate for Governor, felt he would lose votes in the Second Congressional District if two Democrats were fighting each other, and he urged the machine to support Finerty to avoid such a contest. It is quite possible the bosses would have endorsed Finerty, had he backed the Democratic national ticket. But the fiery Congressman had refused to support either Cleve-

$$
\begin{aligned}
& { }^{28} \text { Ibid. , May 10, } 1884 . \\
& { }^{29} \text { Ibid., Oct. 13, Dec. 15, 22, } 1883 .
\end{aligned}
$$


land or Blaine, asserting he was tied to the strings of neither party. But despite his claims of impartiality, his speeches sounded pro-Blaine. As a result Democratic politicians declared they could not support him. Before nominating an opposition candidate, however, they did send a delegation to him, asking him to pledge his support to the entire Democratic ticket. When he refused, the bosses nominated Frank Lawler, a boodle alderman from the Eighth Ward and a member of the Irish National League of America. Finerty responded by publicly endorsing Blaine. 30

Once again Finerty had the backing of most reformminded Irish-Americans -- Daniel Gleason, Richard Powers, Vincent Carroll, and John F. Scanlan. Moreover, the Congressman, now gradually moving back into Sullivan's orbit, received the support of some orthodox Clan-na-Gael Republicans. 31 But Clan Democrats worked for Lawler. Besides, because of his endorsement of Blaine, Finerty lost the support of some independent Democrats, most notably John Comiskey, one of his most ardent backers in 1882. Furthermore, machine politicians like Edward Cullerton and Charles Hildreth were solidly behind Lawler, unlike Sheridan in 1882.32

${ }^{30}$ Chicago Times, Sept. 5, 6, 1884; Chicago Tribune, Aug. 21, sept. 1, Oct. 3, 6, 1884 ; Chicago Citizen. Aug. 2, 23. Sept. 13, 1884; Irish World, Sept. 27, 1884.

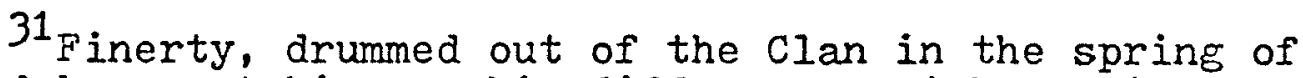
1883, had been patching up his differences with Suliivan and the Clan in 1884. Devoy, "Clan-na-Gael Convention in Boston Split the Organization," "Story of the Clan-na-Gael," Gaelic-American, Nov, 10, 1923, Dec. 27, 1924.

${ }^{32}$ Chicago Tribune, oct. 19, 20, 1884; Chicago Times, 
Despite the odds, Finerty waged a vigorous campaign. He denounced machine politics and espoused his usual policies of a high protective tariff and a strong navy. Lawler, on the other hand, charged the Galwayman with neglecting the cause of the American workingman. At times the campaign became violent as Lawler's friends tried to forcibly break up Finerty rallies. Finerty remained composed, however; after a brick nearly missed him, he calmly remarked: "I have just been looking at this brick and I must say it bears a striking resemblance to Frank Lawler's mug." 33

If Finerty had quick retorts for the verbal and physical assaults of the Lawlerites, they proved ineffective on election day. Though he helped increase Blaine's vote in the Second Congressional District, Finerty lost the election by a substantial margin. ${ }^{34}$ the machine, united this time, had demonstrated that Irish nationalists without the support of professional Irish politicians could not win. Irishmen might like to hear Long John harangue England every August 15, but when it came to bread and butter politics they followed the bosses who provided them with jobs and other favors. 35

oct. $6,21,1884$.

${ }^{33}$ Chicago Citizen, Sept. 27, Oct. 18, 1884; Chicago Tribune, sept. 17,18, 19, 0ct. $3,4,10,13,14,16,28$, 31, Nov. 2, 3, 1884 ; Chicago Times, sept. 3, 1884.

${ }^{34}$ Chicago Tribune, Nov. 6, 1884.

35 See Thomas N. Brown, Irish-American Nationalism, $\frac{1870-1890}{136-37 .}$ (Philadelphia: J. B. Lippincott Co., 1966), pp. 
Finerty's revolt against the regular Irish Democrats was not unique in Chicago; in the same year several Irish-American nationalists throughout the country were leaving the Democratic party to support the Republican ticket. Ever since the end of the Civil War there had been a number of Irish-Americans who felt the Irish had been the slaves of the Democrats. The party of Jefferson and Jackson, they maintained, took the Irish for granted, failing to sufficiently reward them for their loyalty. Some hated the corrupt, venal practices of Irish Democrats and switched to the Republicans as a sign of repudiation. Others were nationalists who believed the Democrats had not sufficiently helped the Irish cause; by supporting the Republicans they hoped they might be able to influence American foreign policy in favor of Ireland. In 1884, with the strength of the two parties in equilibrium, they had a splendid opportunity to show that the Irish could be a deciding factor in a Republican victory.

Irish nationalists hoping to swing the Irish vote to the Republican party in 1884 were aided by the Democratic presidential candidate, Grover Cleveland, who was not particularly attractive to Irish-American citizens. As reform Governor of New York, Cleveland had been an adamant opponent of Tammany Hall, refusing their demands for patronage and blocking the nomination of Tammany politicians. Cleveland also had vetoed a bill lcwering commuter fares in New York 
City, much to the disgust of working-class Irishmen. These actions were not specifically anti-Irish, but since their chief victims were Irish-Americans, the Governor did not endear himself to the Celtic population of New York. At the national convention Tammany politicians opposed Cleveland's nomination; so embittered were they, that they did not endorse the national ticket until september 12.36

The Republican candidate, on the other hand, was more appealing to the Irish. Though a Protestant himself, James G. Blaine had an Irish Catholic mother and a sister in the convent. Furthermore, he had twisted the British lion's tail during his years in Congress and as Garfield's Secretary of state. He also favored a high protective tariff in opposition to British free trade. And finally, Blaine and the Irish shared a common enemy - the middle class reformers who considered the Republican candidate and Irish machine politicians to be inimical to the interests of good government. 37

$36 \mathrm{H}$. Wayne Morgan, From Hays to McKinley: National Politics, 1877-1896 (Syracuse: Syracuse University Press, 1969), pp. 199-212; Brown, Irish-American Nationalism, p. 140; Rexford G. Tugwell, Grover Cleveland (New York: The MacMillan Co., 1968), pp. 67-83; Allan Nevine, Grover Cleveland: A Study in Courage (New York: Dodd, Mead and Co., 1932), pp. 79-155; H. S. Nerill, Bourbon Leader: Grover Cleveland and the Democratic Party (Boston: Little, Brown and Co.' 1957), pp. 14-55; Devoy, "New York Irish Prepare Way for Blaine Campaign," Gaelic-American, Nov, $24,1923$.

37 Morgan, From Hays to McKinley, p. 222; Florence E. Gibson, The Attitudes ô the New York Irish toward State and National Affairs, 1848-1892 (New York: Columbia University Press, 1951), pp. 205, 378; Brown, Irish-American Nationalism, pp. 140-41; Chicaso Times, June 7, 1884; IrishAmerican, June 21, 1884. 
Several Irish-American nationalists declared their support of Blaine immediately after his nomination, without waiting for the Democratic convention. Among these were John Devoy and Patrick Ford, editors respectively of the Irish Nation and the Irish World. Sullivan, however, acted more cautiously. 38 For one thing, he was presently serving as President of the Irish National League of America, and it would have been considered improper had he publicly engaged in partisan politics while holding that post. But more importantly, the crafty Chicago lawyer hoped that his popularity among Irish-Americans would put him in a good position to receive the Democratic nomination for VicePresident.

According to Devoy's memoirs, Sullivan did quite a lot of maneuvering at the Democratic Convention held in Chicago during July. Sullivan sent Judge Richard Prendergast, one of his closest friends at that time, to the Tammany leaders, John Kelly and Thomas F. O'Grady, and he convinced them to drop their opposition to Cleveland, if the New York Governor would agree to accept Sullivan as his runing mate. Before deciding to follow through with his plan, Sullivan decided to hold a caucus of Clan sympathizers attending the Convention to sound out their opinions on the matter. At the meeting Sullivan pretended to know nothing

38 Devoy, "Inside Story of the Blaine Campaign in 1884," Gaelic-American, Dec. 1, 1923; Sullivan to Devoy n. d. (Postmarked, June 10, 1884); Devoy's Post Bag. Vol. II, p. 247 . 

the plan had originated with the Tammany leaders and not himself. Some Clansmen like Patrick Egan, Sullivan's successor as President of the Irish National League of America, ardently supported the idea, claiming that if cleveland rejected it, they would have a perfect excuse for opposing him. Others said they believed Cleveland would never seriously consider the proposition, but that there was no harm in trying. Devoy, however, asserted that he objected to the idea because it would give rise to anti-Catholic nativism and indicate that Irish nationalists were merely place hunters. Finally, he added, Sullivan was ineligible to run for Vice-President because of his Canadian birth. With Devoy's opposition, Sullivan, still pretending he had heard the scheme for the first time, said he wanted the matter dropped, but did insist that he was born in Maine, not Canada. 39

When Sullivan realized he would receive nothing substantial by backing the Democratic ticket, he turned to the Republicans. According to Devoy, the Chicago lawyer and a few of his cronies secretly met with Blaine in western New York, and there the Maine Republican agreed, if elected, to appoint Sullivan as Secretary of the Interior. 40 Thus, in

39 Devoy, "Inside story of the Blaine Campaign in 1884," Gaelic-American, Dec. 1, 1923. The Chicago Times noted that Sullivan met with Kelly. Chicago Times, July 7 , 1884 .

40 Devoy, "Inside Story of the Blaine Campaign in 1884," Gaelic-American. Dec. 1, 1923. 
late August, after resigning as President of the Irish National League of America, Sullivan publicly endorsed Blaine and began a vigorous speaking tour in his behalf throughout several states. Like most Republican politicians Sullivan devoted most of his energy to the crucial state of New York. In New York City he spoke at large Blaine demonstrations, denouncing Cleveland as a friend of British free trade and monopolists. 41

Several other Chicago Irish nationalists also campaigned for Blaine. Sullivan's fellow Clansmen, John M. Smyth and Doctor Patrick Cronin (still on good terms with Sullivan), were two of the most prominent Irish-Americans at Blaine gatherings. A number of independent and Republican reformers -- John F. Scanlan, Richard Powers, P. T. Barry, and John Finerty -- also worked hard for the Republican national ticket. Unlike Sullivan, however, these individuals spent most of their time campaigning in the Chicago area. 42 In fact Sullivan never appeared at a Blaine rally in the city. One reason behind this, of course, was that since Illinois was not a critical state -- there was little doubt Blaine would win it -- it made more sense for a man of Sul-

${ }^{41}$ Chicago Tribune, Sept. 19, Oct. I, 2, Il, Nov. 1, 2, 3, 1884; Chicago Citizen, Sept. 27, 1884; Irish World, oct. 4, 25, Nov. 1, 8, 1884; Devoy, "Irish Place Hunters, Not Burchard Caused Blaine's Defeat," Gaelic-American. Dec. 8, 1923.

${ }^{42}$ Chicago Tribune, oct. $1,2,3,6,7,14,26$, Nov. 3. 1884; Chicago Times, Oct. 11. 1884; Chicago Citizen, Oct. 25, 1884; Irish World, Sept. 6, 27, Oct. 4, 18, 1884; Devoy, "Irish Place Hunters, Not Burchard Caused Blaine's Defeat," Gaelic-American, Dec. 8, 1923. 
Iivan's popularity to concentrate his efforts in states with tight races. Besides, Sullivan probably did not want to directly confront the Democratic machine politicians supporting Cleveland; he would have to continue dealing with them in local politics after November. As it was, there were some Democrats who denounced Sullivan and other Blaine Irishmen, but interestingly enough none of these were members of the Clan-na-Gael. The Democratic Clansmen in Chicago never uttered one word of criticism against Sullivan, even though they were publicly supporting Cleveland. This gives some indication of the amicable relations between Clan members of different political parties. In sharp contrast, Democratic nationalists in the East such as Patrick Collins of Boston and Patrick Meehan, editor of the Irish American, denounced Sullivan for using his position as President of the Irish National League of America for his own personal advancement in American politics. 43

The Irish Democrats, however, had the last laugh. Despite the efforts of Sullivan and others, Blaine lost the crucial state of New York by a mere 1,200 votes and thereby failed to win the election. Many contemporary political observers contended the New York Irish had decided the outcome of the race. According to this theory, Irish voters were going to vote for Blaine en masse until a Protestant minis-

${ }^{43}$ Chicago Tribune, Nov. 3, 1884; Chicago Times, Sept. 9, 28, Oct. II, 14, 16, 17, 19, 1884; Irish-American, June 7, 14, Nov. 1, 1884; Brown, Irish-American Nationalism, pp. 157-58. 
ter, Reverend Samuel Burchard, at a meeting with Blaine denounced the Democrats as the party of "rum, Romanism, and rebellion." Since Blaine failed to repudiate this antiCatholic statement immediately, thousands of Irish New Yorkers were supposed to have deserted the Republican candidate. It is quite possible Burchard changed the outcome of the election, but there were several other variables in New York which were as equally important. 44

Though Illinois was not a critical state -- Blaine won it as expected -- it is interesting to note that Cleveland carried all the top five Irish wards in Chicago, picking up between 54 percent and 66 percent of the votes. The majority of Irish-Americans clearly had followed the direction of the Democratic machine instead of the Republican nationalists. But if we compare Blaine's performance with Garfield's, the Republican candidate in 1880, the issue becomes more complex. In the Eighth and Seventeenth Wards there was no gain in the Republican vote and in the Ninth Ward Blaine received 20 percent less than Garfield. In contrast, Blaine surpassed Garfield in the Fifth and Seventh Wards, both of which were in the Second Congressional District where Finerty was running. Republican newspapers commented on this, and there is little doubt Finerty pulled in a good deal of votes for Blaine. But in comparing the Fifth

44 Morgan, From Hayes to McKinley, pp. 22-23; Nevins, Cleveland, pp. 160-82; D. S. Muzzey, James G. Blaine (New York: Dodd, Mead, 1934), pp. 298-317; Brown, Irish-American Nationalism, p. 141 . 
and Seventh Wards we see that Blaine increased the Republican vote by 13 percent in the former but only 3 percent in the latter. Apparently there was another factor at work; the Fifth Ward Democratic machine was dominated far more extensively by the Clan-na-Gael than that in the Seventh. It is more than likely Clan Democrats, friendly to Sullivan and unenthusiastic about the national ticket, were giving up Cleveland votes in return for Republican support of other Democratic candidates. Though Sullivan never campaigned in Chicago, his influence was still felt! 45

If Irish Republicans were disappointed in 1884, they received an opportunity for revenge four years later. In 1888 the Democrats again nominated Cleveland, while the Republicans turned to Benjamin Harrison, grandson of a former President. Harrison, however, did not have Blaine's appeal to the Irish; he lacked the former candidate's vehement Anglophobia and partially Irish background. This time Republicans hoped to draw the Irish voter mainly on the issues. The most important of these was the tariff, the ...

45 The Irish constituted 55 percent of the electorate in the Fifth Ward; 49 percent in the Seventh; 55 percent in the Eighth; 43 percent in the Ninth; and 37 percent in the Seventeenth. It should be noted that the Irish proportion of the electorate was far greater than their percentage of the total population in these wards. Ethnic composition of voters based on L. P. Nelson, Statistics, Showing by Divisions, Wards, and Voting Precincts, the Original Nationality of the Voters in Chicago (Miss, Newberry Library). Voting statistics are from the Chicago Daily News Almanac for 1885 , p. 34. The Chicago Tribune and the Chicago Evening News both noted Finerty's ability to attract voters for Blaine. Chicago Tribune, Nov. 6, 1884; Chicago Evening News, cited in Irish World, Nov. 22, 1884. 
Democrats favoring a reduction in duties, while the Republicans advocated a continuation of the high protective policy. Harrison's Irish supporters jumped on Cleveland's position, claiming he was a defender of British free trade. But they also attacked the President for being pro-British on other points. They charged that the Bayard-Chamberlain Fisheries Treaty was anti-American and pro-Canadian, and that the Phelps Extradition Treaty (never passed) with England was primarily designed against Irish-American dynamiters practicing their skills in England. Despite the protests and explanations of Irish Democrats like Patrick Collins of Boston and William J. Hynes of Chicago, it was clear the Republicans had effective ammunition in these charges. 46 Though Irish-American Republicans once again worked strenuously for the national ticket, they were divided into two distinct groups, paralleling the split existing in Irish affairs in the United States since 1885. The Sullivan-dominated Clan-na-Gael and followers of Patrick Ford's Irish World supported Harrison under the banner of the Anti-Free Trade League and with the monetary backing of Matthew Quay, Republican National Chairman and a boss in Pennsylvania pol-

46 Harry J. Sievers, Benjamin Harrison: Hoosier Statesman, From the Civil War to the White House, 1865-1888 (New York: University Publishers, Inc., 1959), pp. 398409; Brown. Irish-American Nationalism, pp. 141-42; Joseph P. O'Grady, "Irish-Americans and Anglo-American Relations, 1880-1888" (Ph. D. Dissertation, University of Pennsylvania, 1965), p. 65; William J. Hynes, Letter to the Editor, Chicago Tribune, Nov. 5, 1888; Chicago Tribune, Nov. 1, 3, 5, 1888; Chicago Citizen, May 19. June 9, 30, July 14, Aug. 11, 25, Sept. 1, 0ct. 6, 27, 1888. 
itics. Republican Clansmen in Chicago were quite active in the campaign. John M. Smyth drummed up votes for Harrison in the city, while John F. Finerty travelled throughout the Midwest denouncing the Democrats and free trade. The IrishAmerican Republican Club of Cook County, led by Matthew P. Brady and John F. Beggs, organized a delegation of 400 Irish Chicagoans to visit Harrison in Indianapolis. Sullivan, however, occupied with Clan-na-Gael matters, did not take an active part in the election, but was quite busy behind the scenes. 47

Many of Sullivan's enemies also backed Harrison, but worked independently of his clique. Individuals such as John Devoy and Doctor William Carroll formed the Irish-American Anti-Cleveland Protection League and received financial assistance from Wharton Barker, a rich Philadelphia steel industrialist and political antagonist of Quay. 48

No matter which camp they were in. Irish Republicans received added encouragement during the last weeks of the campaign with the publication of the famous Murchison letter,

47 Irish World, Aug. 11, Sept. 22, 0ct. 27, Nov. 3, 1888; Chica.50 Citizen, Dec. 22, 1888; Chicago Tribune, Sept. 12,16, oct. $5,6,11,19,20,21$, Nov, 1,2, 4, 5, 1883, Chicago Inter Ocean, Sept. 14, 15, 1888; Benjamin Harrison, Speeches of Benjamin Harrison, Edited by Charles Hedges (New York: United States Book Co., 1892), pp. 125-26; Official Proceedings of the Republican National Convention, 1888 (MinneapoIis: Charles W. Johnson, 1903), pp. iii, 91; Brown, IrishAmerican Nationalism, p. 139; O'Grady, "Irish-Americans and Anglo-American Relations, 1880-1888," p. 64.

48 Brown, Irish-American Nationalism, p. 139; 0'Grady, "Irish-Americans and Anglo-American Relations, 1880-1888," pp. 63-64. 
in which the British minister in Washington, Sir SackvilleWest, declared it would be better for English interests if Cleveland were elected. Republicans claimed that this was proof of Cleveland's pro-British leanings. Iike the Burchard statement four years before, contemporaries contended that the British minister's letter was crucial in turning the election. Many more Irishmen, they asserted, would have voted for Cleveland, had Sackville-West been more discreet. As it was, Harrison won New York by a close vote, thereby capturing the White House. It is possible the British diplomat's blunder cost Cleveland the election, but it is noteworthy that a recent study has shown that cleveland received more Irish votes in New York in 1888 than in 1884, when he was not saddled with the Murchison letter. 49 In Chicago, however, Cleveland did slightly worse in Irish districts in 1888 than in 1884.50

Irish-American Republicans, believing they had played a vital role in electing Harrison, expected a considerable amount of patronage. Actually, they received little. The Devoy faction, aligned with Wharton Barker, were bitterly disappointed when they were denied a slice of the victory

\section{${ }^{49}$ Brown, Irish-American Nationalism, pp. 142-44;} See also Sievers, Benjamin Harrison: Hoosier Statesman, pp. 409-12; Morgan, From Hayes to McK inley, pp. 314-19.

50 Based on a comparison of Cleveland's vote in the heavily Irish Second Congressional District in 1884 and in 1888. The ward boundaries in chicago were altered between the two national elections, thus precluding a ward-by-ward examination. For 1888 election returns see Chicago Daily News Almanac for 1889 , p. 104. 
pie; in 1892 they retaliated by supporting Cleveland. The Sullivanites, with the aid of Boss Quay's influence, fared better. Doctor George Pepper, a Protestant minister and Irish nationalist from Ohio, was appointed as American counsel in Milan, and Patrick Egan, a citizen since only mid1888, became Minister to Chile. Egan, a super American nationalist as well as an Irish one, almost started a war a few years later between Chile and the United States. 51

Republican Irish nationalists could take some satisfaction in Harrison's victory. They had demonstrated -- at least enough to convince themselves -- that they could pull a sufficient number of voters away from the Democrats to change the outcome of an election. But by and large, their grandiose visions went unfulfilled. Harrison's administration did Iittle for Ireland; it was certainly no more antiBritish than its predecessor. Furthermore, the nationalists' dreams of holding important political positions never materialized. For men who aspired to the Vice-Presidency of the United States, the ministry to Chile must have at times seemed meager. But in reality Irish Republicans deserved no more than what they received. They had failed miserably to make any significant inroads on the Irish voter's attachment to the Democratic machine. The urban Irish, receiving jobs and other favors from boss politicians, were most reluc-

51 Irish World, Mar, 20, 1889; Irish-American, Nov. 24, Feb. 16, Mar. 20, April 6, 1889; Chicaro Citizen, Feb. 8, Mar. 30, April 6, 13, May 25, 1889; Sievers, Benjamin Harrison, Hoosier President, pp. 13, 38, 192-97. 
tant to give these up and vote according to the direction of Republican Irish nationalists. The nationalists were only politically successful when, as in Chicago, they were themselves machine politicians. In New York, for example, where nationalists and boss politicians went their separate ways -- Iargely because the Clan-na-Gael leadership there refused to co-operate with what they considered a corrupt system -- the former had no chance of defeating the latter on their own battleground. 52 . In time, of course, as Irish-Americans moved from the ghettoes and into the middle class their dependence on the Democratic machine waned considerably. But by then the Irish had also lost most of their identity. Aronically, when Irish-Americans reached the stage where they could afford to ignore the pressures of boss politicians and vote as a block for Ireland, they had little interest in their homeland. And so for the present day Irish nationalists -- the few that are left -the problem lies not with the Tammany Halls, but in making Irish-Americans aware of their past. They, like the Irish Republicans in the $1880^{\circ} \mathrm{s}$, are dreaming the impossible dream.

52 See Brown, Irish-American Nationalism, pp. 136$37,143-46$. 
THE CLAN-NA-GAEL AND THE STRUGGIE FOR AN IRISH NATION

In 1870 Isaac Butt founded the Home Rule Movement. Butt, a Dublin barrister and a Protestant, was a conservative on social matters. He believed that continued English mistreatment of Ireland would make the Irish masses radical and destroy the old social order. Originally he had hoped Irish problems could be ameliorated within the existing political framework, but by 1870 he realized the need for an alternative system. Consequently, he established the Home Government Association with the object of attaining Irish self-government for local matters. Under his plan Westminster would continue still to legislate on imperial affairs. Butt had no intention of setting up an independent Irish state; he simply wanted to federalize the relationship between Great Britain and Ireland.

In the early days of the Home Government Association a considerable number of its members were, like Butt, conservatives disgusted at the growing strength of radicalism in the British Isles. Unlike Butt, however, most of these conservatives had no deep sympathy for Catholic grievances. They soon began to realize that a separate Irish legislature, which Catholics might eventually dominate, would inaugurate more problems then it would solve. Therefore, the conservative membership in the association dwindled, and 
the traditionally nationalist element came to the forefront. This was demonstrated most forcibly in 1873 when John Barry, a former Fenian and member of the Irish Republican Brotherhood, established the Home Rule Confederation of Great Britain with Butt as President. Barry and his I. R. B. colleagues supported Home Rule not as a final solution to the Irish question, but as a step in the right direction. Butt's efforts in behalf of Irish Federalism were rewarded in the election of 1874. The Home Rulers scored a tremendous victory, electing fifty-nine members to Parliament. Shortly thereafter they established the Home Rule Parliamentary Party. Members were required to vote only as a block on the question of Irish self-government. On all other issues, including Irish social and economic grievances, they could follow an independent course. By continually presenting the demand for Home Rule in a dignified manner before the House of Commons, Butt hoped the British would eventually see the wisdom of his federal solution to the Irish question. His policy, however, was unsuccessful because of his inabilities as a leader and the lackadaisical attitude of many Home Rule M. P.'s. But, more important, British legislators simply refused to listen to Butt's moderate proposals. By 1876 many Irish nationalists were disillusioned with Butt and the Home Rulers. ${ }^{1}$

$1_{\text {For Isaac Butt and Home Rule see Terence deVere }}$ White, The Road of Excess: A Biography of Isaac Butt (Dublin: Brown and Nolan, 1946); Lawrence J. McCaffrey, Irish Federalism in the 1870's: A Study in Conservative Nation- 
A few Irish M. P.'s, however, disagreed with Butt's policy of conciliation. In 1875, Joseph Biggar, a Belfast merchant and I. R. B. member, began to delay legislation by filibustering. Biggar later received support from other Irish M. P.'s -- O'Connor Power, a fellow I. R. B. man, Frank Hugh $0^{\prime}$ Donnell, and most notably Charles Stewart Parnell. By using obstructionist tactics these individuals hoped to tie up legislation to such an extent that the British would realize it would be preferable to grant the Irish a parliament for their own affairs. ${ }^{2}$

Parnell, unnoticed when he first entered Parliament, gradually emerged as the leading obstructionist. Born in County Wicklow of a Protestant Irish father and an American mother, Parnell, like so many other nationalists, came from a mixed ethnic background. In many ways he was a strange man; he was quite aloof at times and had few close friends. But he was a master politician whom the British found difficult to handle, since he refused to play the parliamentary game according to their rules. Young Parnell and the aging Butt soon came into conflict over the former's obstructionist policy. Parnell secured his first major triumph over

alism, American Philosophical Society Transactions (Philadelphia, 1962); David Thornley, Isaac Butt and Home Rule (London: Ambassador Press, 1964$)$.

2 For the obstructionists see R. Barry 0.Brien, The Life of Charles Stewart Parnell (London: Smith, Elder and Co., 1899), Vol. I, pp. 70-152; Frank Hugh 0'Connell, A History of the Irish Parliamentary Party (London: Longmans, Green and Co., 1910), Vol. I, pp. 106-253; T. P. O'Connor, Memoirs of an old Parliamentarian (Iondon: Ernest Benn Ltd., 1929): Vol. I, pp. 128-35; Thornley, Butt, pp. 227-387. 
the old leader in 1877, when the Fenian-dominated Home Rule Confederation of Great Britain dumped Butt as their chief and replaced him with Parnell. 3

Across the Atlantic Clan-na-Gael leaders watched the obstructionists with mixed emotions. Traditionally, of course, revolutionaries had considered taking a seat in Parliament tantamount to recognizing the legitimacy of the British government. They distrusted parliamentarians as compromisers, chiefly interested in promoting themselves and not the welfare of their country. The pusillanimous performance of Irish M. P.'s during the forties and fifties certainly confirmed their opinion in this regard. But on the other hand there was something about Parnell and his colleagues that appealed to Irish-American extremists. Parnell's genuine concern for Ireland, and his contempt for British methods, struck a friendly cord in their rebel hearts. Parnell, Clansmen were beginning to realize, was not the typical type of Irish M. P. 4

As early as 1877 James J. O'Kelly, a Clan-na-Gael man, who eventually returned to Ireland and was elected to Parliament, had suggested that the Clan support Parnell. Then, on a trip to Europe during the winter of 1877-78 Doctor William Carroll, Chairman of the Clan Executive Committee, met Parnell. Though he failed to convince the young

3R. B. O'Brien, Parnell, Vol. I, pp. 70-152.

4 Thomas N. Brown, Irish-American Nationalism, $1870-$ 1890 (Philadelphia: J.B. Lippincott Co., 1966), pp. 79-81. 
Anglo-Irishman to join the revolutionary movement, he was impressed by his nationalist outlook. When Carroll returned to the United States he discussed the situation in Ireland with Devoy and other Clansmen. There gradually emerged what became known as the New Departure. Simply stated, it went like this. The Clan-na-Gael realized that the Irish Republican Brotherhood, suffering from ineffective leadership and internal dissension, lacked the support of the Irish masses. In contrast, the obstructionist parliamentarians seemed to be the most viable expression of nationalist sentiment in the country. Consequently, the Clan decided that under existing circumstances it would be best to support Parnell and other M. P.'s of his caliber. Secondly, in order to bring the Irish peasant into the mainstream of Irish nationalism, the Clan would champion the cause of land reform. It hoped that in this way a sense of nationalism would develop among the Irish people. When the people were thoroughly aroused -- hopefully by 1882, the centenary of the Volunteer movement -- the nationalists in Parliament would withdraw from Westminster and set up an independent legislature in Dublin. All Irishmen would then be ready to face the final bloody showdown with England. 5

5 Brown, Irish-American Nationalism, pp. $81-98 ; \mathrm{T}$. W. Moody, "The New Departure in Irish Politics, 1878-79," Essays in British and Irish History in Honour of James Eadie Todd, edited by T. W. Moody, H. A. Crone, and D. B. Quinn, (London: Muller, 1949). See also R. B. O'Brien, Parnell, Vol. I, pp. 158-69; M. M. 0'Hara, Chief and Tribune: Parnell and Davitt (Dublin: Maunsel and Co., 1919), p. 79; William O'Brien and Desmond Ryan (eds.), Devoy's Post Bag, 
The first public pronouncement of the New Departure came in October, 1878 when Devoy, after consulting with other Clan leaders, sent a telegram to Parnell pledging him the support of the Clan, if he in turn would endorse a general declaration of Irish self-government instead of Butt's limited federalism. Secondly, he asked Parnell to lend his support to agitation for land reform with the object of eventually achieving peasant ownership of the land. 6

Though Parnell failed to respond to this proposal, the Clan-na-Gael continued its plans to establish an alliance between the revolutionary and constitutional wings of Irish nationalism. With this end in view, Devoy and Michael Davitt, an I. R. B. man recently released from a British prison, traveled to Europe to convince Parnell and the I. R. B. leaders to co-operate in their venture. They were, however, only partially successful. In January, 1879, Devoy and Davitt met with the I. R. B. Supreme Council in Paris. The I. R. B. chiefs, Charles Kickham and John O'Leary, opposed the New Departure on two essential points. Believing that nothing good would come from constitutional activity, they refused to support the parliamentary nationalists. Furthermore, following in the tradition of the Young Irelanders,

1871-1928 (Dublins C. J. Fallon, 1948-53), Vol. I, pp. 298$99,370-72$; James J. O'Kelly to Devoy, Aug. 5, 21, 1877 , William Carroll to Devoy, Nov. 16, 1877; Carroll to Patrick Mahon, Mar. 30, 1878, Devoy's Post Bag, Vol. I, pp. 267$70,279-82,324-5$.

${ }^{6}$ Devoy's Post Bag, Vol. I, p. 370, R. B. O'Brien, Parnell, Vol. I, pp. 168-69. 
who had hoped to convert the landlords to nationalism, they would have nothing to do with agrarian reform. Devoy and Davitt, however, succeeded in wringing one concession from the Supreme Council. It agreed to permit its members to engage in political activity to gain control of local offices. Despite the hostile attitude of the Supreme Council to the New Departure, many rank and file members of the $I . R . B$. co-operated with the constitutional and agrarian movements.?

Negotiations with Parnell proved far more fruitful. Devoy met Parnell twice, once in Boulounge in March, 1879, and then in Dublin a few months later. Nothing concrete came from the first conference, though Devoy was favorably impressed with Parnell's flexible attitude toward revolution. The second meeting was crucial. On June 1, 1879, Devoy, Davitt, and Parnell met in Dublin and cemented the New Departure. According to Devoy's account, both Parnell and Davitt, now increasingly involved in the struggle for land reform, agreed that neither the constitutional nor agrarian movements would work against the interests of Fenianism and that preparations for a rebellion should continue. Devoy in turn pledged the Clan's co-operation with the Parnellites and the land movement. Later on Parnell denied he had made such an

7R. B. 0'Brien, Parnell, Vol. I, p. 177; Mark F. Ryan, Fenian Memories (Dublin: M. H. Gill and Son, 1946), pp. 6465. 91-92; John Devoy, Recollections of An Irish Rebel (New York: Charles Young, 1929), p. 314; Devoy's Post Bag, Vol. I, p. 382; John O'Leary to Devoy, Nov. 8, 1878, Devoy's Post Bag, Vol. I, pp. 373-74; Brown, Irish-American Nationalism, pp. 93-95; Marcus Bourke, John O'Leary: A Study in Irish Separatism (Tralee, Co. Kerry: Anvil Books, 1967), pp. $16,54-55,153-62$. 
agreement with Devoy. The truth of what really happened will never be known, but it is more than likely Parnell gave Devoy some indication that he would support a revolution if the opportunity arose. 8

At this same meeting Parnell also agreed to Davitt's request that he take an active part in the campaign for agrarian reform. The land movement had recently picked up momentum. After the disastrous harvest of 1878 , the number of evictions had increased tremendously as tenants failed to meet the exorbitant rents of the landlords. Discontent mounted and in April, 1879 the first major demonstration against landlordism took place under the leadership of Davitt at Irishtown, County Mayo. Thus, the movement had considerable popular support when Parnell decided to enter it publicly in June. Two months later in August Davitt organized the Land League of Mayo. In October the Irish National Land League was founded with Parnell as President, thereby uniting the constitutional nationalist and agrarian movements under one leader. 9

The chief object of the Iand League was to reduce rack rents, stop evictions, and agitate for the eventual

\section{Gaelic-American, Oct. 13, 1906; Devoy, Recollec-} tions, p. 284; Devoy's Post Bag, Vol. I, 401-02; R. B. O'Brien, Parnel1, Vol. I, pp. 175-77; Nichael Davitt, The Fall of Feudalism or the Story of the Land League Revolution (New York: Harper, 1904), pp. 116-37; Brown, IrishAmerican Nationalism, pp. 95-98.

$9^{9}$ Davitt, Fall of Feudaliam, pp. 141-80; R. B. 0.Brien, Parnell, Vol. I, pp. 178-97; OHara, Chief and Tribune, $\mathrm{pp}$. 94-100; Norman D. Palmer, The Irish Land Learue Crisis (New Haven: Yale University Press, 1940), pp. 132-43. 
establishment of peasant proprietorship of the land. The League used quite effective methods. Usually League officials stipulated what they considered to be a fair rent for a particular farm. If the landlord refused to comply and an eviction occurred, the League would then pressure other tenants not to rent the land. Another method was the boycott - - the name derives from Captain Boycott, a hated land agent in County Mayo -- which sought to cut off an offending landlord and his collaborators from any contact with their neighbors. For example, the landlord's laborers and household servants received notices to leave their employment; shops refused to sell provisions to the landlord; and in some cases mail was not delivered. Along with peaceful methods like the boycott, violent means unauthorized by League authorities were also instrumental in putting pressures on landlords to lower rents and halt evictions. In many instances these were more persuasive than boycotting and the like. 10

Shortly after the Land League was established, Parnell decided to come to the United States to raise funds for the cause. Arriving in January, 1880, Parnell had an enormously successful ten weeks tour. He discussed the Irish problem with several American public officials and addressed a joint session of Congress. Traveling over ten thousand miles, he visited sixty-two cities. In many of

${ }^{10}$ Palmer, Land League Crisis, pp. 175-217. 
these Clan-na-Gael members in sympathy with the New Departure helped prepare arrangements for his reception. In Chicago, for example, extremists like Sullivan and Finerty cooperated with moderates to provide a rousing welcome for the Irish leader. Before he returned to Ireland in March, 1880, to prepare for a general election, Parnell had raised over two hundred thousand dollars for the Land League and the distressed peasants of Ireland. 11

Prior to his departure for Ireland, Parnell called a meeting in New York to make arrangements for the formation of an affiliate Land League in the United States. This decision clearly brought to the forefront the festering divisions within the Irish-American community.

First of all there was the Clan-na-Gael in which there were varying opinions on the value of an American Iand League. Individuals Iike Devoy strongly supported the establishment of a Land League in the United States, believing it would not only help to inform Americans about the

${ }^{11}$ R. B. O'Brien, Parne11, Vol. I, pp. 200-04; Davitt, Fall of Feudalism, pp. 193-210; T. M. Healy, Letters and Leaders of My Day (London: Thornton, Butterworth, 1929), Vol. I, pp. 77-88; Philip H. Bagenal, The American Irish and Their Influence on Irish Politics (Iondon: Kegan Paul, Trench and Co., 1882), pp. 198-204; Circular from William Carroll, Chairman of the Clan-na-Gael Executive Committee to the Clan camps, Jan. 5, 1880; Sullivan to Devoy, Mar. 5 , 1880, Devoy's Post Bag, Vol. I, pp. 479-80, 497-98; Circular from William Carroll, Chairman of the Clan-na-Gael Executive Committee to the Clan camps, April 19, 1880, Special Commission Act, 1888, Reprint of the Shorthand Notes of the speeches, Proceedings and Evidence Taken Before the Commissioners (London: H. H. S. 0., 1890), Vol. IV, p. 518. For Parneli's reception in Chicago see Irish World, Jan. 3 , 10, Feb. 21, Mar. 6, 1880. 
Irish problem, but also serve as a recruiting ground for new Clan-na-Gael members. ${ }^{12}$ But other Irish-American extremists looked differently at the situation. While most favored the Land League in Ireland, where nationalist sentiment needed a spurt, many adamantly opposed setting up an American Land League. The Land League, they felt, would only undermine the influence of the Clan-na-Gael. Strangely enough, one of the main opponents of an American Land League was Doctor Carroll, one of the Clan-na-Gael chiefs instrumental in the formation of the New Departure. Carroll, however, had become disenchanted with Parnell during the latter's visit to America. In part the reasons were personal -- Carroll felt Parnell had slighted him -- but he also believed that the Irish leader and his colleague, John Dillon, were planning to build up the Land League as a rival to the Clan-na-Gael. It would be better, Carroll contended, for the Clan to get out of the Land League business before it was too late and the Clan was destroyed. 13

Since its leaders were divided on the Land League,

12 For the involvement of New York Clansmen in the Land League prior to the national convention in May see Irish-American, Mar. 13, April 3, 1880.

13 Besides Carroll two of the other chief foes of the American Land League on the Clan-na-Gael Executive Committee were Edward O'Meagher Condon of Washington and Michael Boland of Louisville: Carroll to Devoy, flar. 12, 23, April 9, 20, 23, 29, 30, 1880; Boland to Devoy, Nov. 10, 1880; W. M. Lomasney to Devoy, Dec. 16, 1880, Devoy's Post Bas, Vol. I, pp. 499-501, 504-508, 511, 515-18, 520-23, Vol. II, pp. 13, 25-26; Carroll to John 0.Leary, Oct. 11, 1885, 0'Leary Papers, MSS 8001, National Library of Ireland; R. B. 0.Brien, Parnell, Vol. I, pp. 200-01, 241-43. 
the official policy of the Clan-na-Gael was somewhat ambivalant. While the Clan Executive Committee encouraged its members to secure control of Land League branches if they were established in their areas, it warned them not to make any strenuous efforts on behalf of the new organization. One month prior to the first national convention of the Land League (May, 1880) the Executive Committee cautioned members :

We recognize, however, the danger of giving our energy and ability to any public movement to such an extent as to neglect our own special work and duties. We earnestly urge the members of the V. C. [Clan-na-Gael] hereafter to give special attention to the extension of the organization and only to give so much of their time and attention to public movements of whatever as can be utilized for the benefit and growth of the V. C. and the achievement of the real revolutionary work which remains to be done throughout the secret work of the V. C. ${ }^{14}$

If the Clan-na-Gael had mixed emotions toward the Land League, a second group, which we might label conservatives, supported it enthusiastically. These individuals hated England and wanted an independent Ireland, but, unlike the Clan, they were opposed to violence. Many were Catholic priests who followed Rome's line on revolution. Others were lace curtain Irish who refused to support the Clan, for fear it would hurt their standing in American society. Before the formation of the Iand League they had been floating

${ }^{14} \mathrm{Circular}$ from William Carroll, Chairman of the Clan-na-Gael Executive Committee, April 19, 1880, Special Commission, Vol. IV, p. 517. 
around without any strong cohesive organization. Viewing Parnell as a non-violent champion of Irish rights, they were only too happy to aid him both morally and financially. 15

The third major faction in Irish-America was the social reform followers of Patrick Ford. Ford, through the pages of the Irish World, had long been a champion of social justice in both the United States and Ireland. A passionate opponent of capitalism, he denounced interest on money and rent for land as two of the greatest social evils. Unlike the Clan and the conservatives, Ford did not advocate peasant ownership of the land but rather land nationalization along the lines of Henry George. Thus, for Ford the Land League was a means to establish this long cherished dream. He also believed in achieving Irish independence through force, but in contrast to the Clan (for which the Iand League was primarily a means of arousing nationalist sentiment), he considered land reform as important as Irish selfgovernment. ${ }^{16}$. Because of his socialist beliefs Ford refused to co-operate in the formation of a central American Land League, dominated by Clansmen and conservatives. Instead he organized his own league. Private individuals or branches affiliated with his faction sent their donations to the Irish World. The newspaper then published the names of the contributors and sent the money on to Patrick Egan,

\section{${ }^{15}$ See Brown, Irish-American Nationalism, p. 104;} Bagenal, The American Irish, p. 220. 16 Brown, Irish-American Nationalism, pp. 49-60, 104- 
the Irish Land League Treasurer. The Irish World became the most successful channel of Land League funds; before dissolving his League in October, 1882, Ford had forwarded $\$ 343,000$ to Ireland. 17

Although Ford refused to participate in the first convention of the Irish National Iand League of America, held in New York's Treanor Hall on May 18 and 19, 1880 , conservatives and Clansmen in sympathy with Devoy's point of view attended. All agreed on the necessity of a central American Land League, but there was a dispute on the treasury. Devoy and the Clan delegates wanted a central treasury, hoping in this way to have a more united and powerful Irish-American organization. Most conservatives, however, opposed this plan fearing extremists would get control of the funds. Instead, they supported Parnell's proposal that each American branch forward its proceeds directly to Dublin. Both sides eventually reached a compromise; they agreed that there would be a central treasury, but that it would be under the control of a priest, Father Lawrence Walsh of Waterbury, Connecticut. 18

Besides capturing the treasury, conservatives were elected to most of the other offices. James McCafferty, a lawyer from Lowell, Massachusetts, and William Purcell, a

17 Irish World, oct. 14, 1882.

${ }^{18}$ Davitt, Fall of Feudalism, pp. 247-49; Davitt, The Times-Parnell Commission: Speech Delivered by Michael Davitt in Defence of the Land League (London: Kegan Paul, Trench, Trubner and Co., 1890), pp. 129-41; Irish-American, May 29, 1880; Irish World, Nay 29, 1880. 
machine politician from Rochester, were named respectively President and Vice-President. Michael Davitt, elected as secretary, was the only bona-fide revolutionary among the officials, and he was quickly walking the path toward social reform and away from extreme nationalism. 19

From its very inception the American Land League had a stormy existence. One of its chief problems centered around the officers. President McCafferty had a reputation as the handsomest man in New England but little else. He was a completely ineffectual leader; he took little interest in the League and resigned after the first couple of months in office. He disappeared shortly thereafter, and many of his friends believed he was dead; but he showed up a few years later with the news that he had been running a college in Argentina. Davitt, the Secretary, was a capable man, but since he spent a great deal of his time organizing League branches throughout the country, he was not available at the central offices to give direction to the affairs of the organization. At any rate he returned to Ireland in the latter part of the year. Only Father Walsh, the Treasurer, remained to look after the League. 20

The regular Land League also suffered from the competition of the Irish World Iand League. Subscribers to Ford's newspaper did not necessarily always agree with his

\section{${ }^{19}$ Irish-American, May 29, 1880. ${ }^{20}$ Irish-American, Jan. 8, 1881, Jan. 12, 1884; Davitt,} Speech, pp. 105-106; 0'Hara, Chief and Tribune, pp. 135-38; 148; Davitt, Fall of Feudalism, p. 252. 
social philosophy, but many liked to see their names in print, and thus sent their donations to the Irish World. Moreover, the attitude of the Clan-na-Gael in certain areas did not further the development of the Land League. For instance, in Chicago, though the Clan did not prohibit members from participating in the League, it showed little enthusiasm for building up the organization. Sullivan, then member of the Clan Executive Committee from Illinois, believed "the work given to such organizations is so much taken from our strength." As a result no effort was made to establish regular Land League branches in Chicago until November, 1880 when a group of conservatives and Clansmen held a meeting for that purpose. Up until that time Ford's faction thoroughly dominated the Iand League movement in the city. 21 In contrast, in New York where Clan leaders like Devoy and Doctor William Wallace vigorously supported the League, several extremist-dominated branches had been in existence since the early part of the year. 22

It was with the hope of putting the Land League on a firmer footing that Father Walsh announced the organization would hold its second national convention in Buffalo on January 12 and 13, I881. The conservatives clearly dominated the gathering, partially because the Clan had made

${ }^{21}$ Devoy, Land of Eire (New York: Patterson and Neilson, 1882), p. 84. Davitt, Speech, p. 77; Sullivan to Devoy, Sept. 14, 1880, Devoy's Post Bag, Vol. I, pp. 549-50; ChiCago Tribune, Nov, 29, 1880; Irish World, Dec. 11, 1880, Mar. 26, 1881.

${ }^{22}$ See Irish-American, Mar. 13, April 3, 1880. 
no concerted effort to send delegates. But the location of the convention was also important. Of the 129 delegates, 124 came from the New England and Middle Atlantic states where the conservatives had their strongest foothold. IIIinois, dominated by the Clan-na-Gael, had only one representative, a priest from Lacon. 23

From the very beginning the conservatives ran the convention. Father Patrick Cronin of Buffalo gave the opening address and Father Daniel O'Connell of Oswego, New York served as temporary chairman. The permanent officers were, likewise, mostly conservatives. Patrick Collins of Boston and Father Cronin were named respectively as President and First Vice-President, while Father Walsh remained on as Treasurer. The only extremist elected to a national office was the Second Vice-President, Mayor Terrence Powderly of Scranton. Furthermore, the conservatives scored another victory when the convention passed a resolution condemning "all forms of violence" to achieve Irish self-government. 24 The Clan considered this a direct attack on its organization. The Executive Committee promptly notified the camps that a group had been organized at Buffalo which was "now actively at work inside that organization [Land League] with the ob-

23Irish-American, Dec. 20, 1880; "Second Annual Convention of the Irish National Land League," Special Commission, Vol. XI, appendix, pp. 708-18.

24 "Second Annual Convention of the Irish National Land League," Special Commission, Vol. XI, appendix, pp. 708-18; Davitt, Speech, pp. 144-46; Irish World, Mar. 26, April 2, 1881. 
ject of gradually sapping the foundation of our organization and building up a power capable of crushing out the revolutionary spirit while ostensibly working for Ireland." There was a conspiracy, the Clan contended, both in the United States and Ireland to turn the land movement into "a mere old-fashioned Whig's agitation, with a strong antinational policy, as soon as the so-called extreme leaders are safely lodged in prison." The time had come for the Clan to take a new look at its position toward the American Land League; clearly the present ambivalent policy could not continue. Either the Clan would have to work as a unit to control the League and thus insure it would not be detrimental to its interests, or else it would have to pull out entirely and hope the League would fold without the support of extremists. Until it decided on a general course of action, the Executive Commiteee urged members to retain the money in local branches under their control. 25

Meanwhile, in Chicago, Clansmen responded to the Buffalo convention by making a concerted effort to take over the regular Land League movement, which had only begun to develop in the city since the beginning of the year. Not only did they establish individual branches under their influence, but they also captured the machinery of the Chicago Land League, the central organization comprising represen-

${ }^{25}$ Circular from the Chairman of the Clan-na-Gael Executive Committee, Mar. 1, 1881, Special Commission, Vol. IV, pp. 539-41. See also Devoy to James Reynolds, ifiar. 26, 1881, Devoy's Post Bage Vol. II, pp. 55-56. 
tatives from all Land League branches in the city (excluding the Irish World clubs which refused to co-operate). Furthermore, since the Clan greatly outnumbered the conservatives at the organizing convention of the Illinois State Land League held on May 1, 1881, extremists also secured control of the state-wide organization. Clansmen were elected to most of the important offices. For instance, Father Maurice Dorney, the Stockyards priest, and Dennis $0^{\prime}$ Connor, a close friend of Sullivan, were named respectively as President and Treasurer. Thus, while the Clan might fear the direction the American Land League was taking, it could rest assured the Illinois League was safely in its hands. 26

If the Clan-na-Gael faced difficulties with the American Land League, it encountered even greater problems with its home organization, the Irish Republican Brotherhood. When the Clan accepted the New Departure in 1879, it did so with the understanding that it would eventually culminate in a revolution for independence. Irish-American extremists set their hopes for an uprising in 1882, the centenary of the Irish Volunteer movement. But such a program required a highly efficient revolutionary organization in the British Isles. To the disgust of the clan it was becoming increasingly evident that the I. R. B. did not fit the bill. Through its policy of expelling members involved in Parliamentary politics and the Land League, the I. R. B. lost many

${ }^{26}$ Chicago Tribune, Nov. 29, 1880, May 2, Aug. 15. 1881; Irish World, Dec. 11, 1880, Jan. 29, Mar. 26, Aug. 27. 1881; Irish-American, April 30, May 14, 1881. 
leaders -- Patrick Egan, Joseph Biggar, Michael Davitt, and James J. O'Kelly -- with drive and energy. Those remaining, the "pure" revolutionaries, were at best mediocre. Two of the chief leaders, Charles Kickham and John O'Leary, were dreamy, literary men, who for Ireland's sake would have been better off devoting their full time to intellectual concerns and leaving the art of war to others. Under these individuals and their colleagues the I. R. B. was usually in a state of shambles. 27 When in 1879 the Clan emissaries, Devoy and General Millen, inspected the I. R. B. they found it in an anemic condition. Military training was poor and arms were not concealed carefully. ${ }^{28}$ Conditions seemed to improve temporarily in the winter of 1880-81, as an increasing number of arms were shipped into Ireland and military instruction was upgraded. But the $I . R . B$. continued to oppose any kind of co-operation with the Land League. It refused, for example, to send arms to the distressed peasants in the West. ${ }^{29}$ By the following spring the situation

27Devoy to Reynolds, Feb. 24, 1879, J. B. O'Reilly to Devoy, Aug. 2, 1880, Devoy's Post Bag,Vol. I, pp. 404407, 545-46; R. B. 0'Brien, Parnell, Vol. I, p. 156. For O'Leary's life see Bourke, O'Leary; O'Leary, Recollections of Fenians and Fenianism, 2 vols. (London: Downey and Co., 1896). For Kickham see James Maher (ed.), The Valley Near Slievenamon: A Kickham Anthology (Mullinahone, Co. Tipperary: By the Author, 1942).

28 Devoy to Reynolds, Feb. 24, 1879, Devoy's Post Bag, Vol. I, pp. 404-407; "Report of Military Envoy to J, Read at Ninth Convention of the V. C.," Special Commission, Vol. IV, pp. 570-77.

29 Davitt to Devoy, Feb. 6, 1880; Carroll to Devoy, Feb. 6, 1880; J. J. O'Kelly to Devoy, Feb. 11, 1880; Report 
had reverted back to its previous lethargic state with little active preparatory work being done. 30

Across the Atlantic the Clan-na-Gael viewed the policies of the I. R. B. with alarm. The Clan was under increasing pressure from Irish-American extremists, both within and outside its organization, to show some concrete results for all the money collected. Most Clansmen believed the I. R. B. was wasting a golden opportunity to develop a powerful revolutionary force. 31 In september, 1880, for example, Sullivan wrote Devoy:

I fear our work and money are wasted while the $I . R$. B. is under control of men who lack activity and brains. . - I must confess for myself that I am sorely disappointed at affairs in Ireland, especially when I am forced to believe that there never was better material there to form a revolutionary organization. Unless a change is made, my judgement is that the home connection ought to be dropped. We could do something if alone. We can do nothing unless the home management is changed. 32

of the Revolutionary Directory, Nov. 18, 1880; Devoy to Reynolds, Dec. 10, 1880; Davitt to Devoy, Dec. 16, 1880; 0'Leary to Devoy, Dec. 28, 1880; Lomasney to Devoy, Feb. 23. 1881; Devoy to Reynolds, Mar. 26, 1881, Devoy's Post Bag, Vol. I, pp. 484-85, 488-90, Vol. II, pp. 14-15, 19, $21-25,27-28,44-45,55-56$.

30 Minutes of the Clan-na-Gael Executive Committee meeting, June 1, 1881, Devoy's Post Bag, Vol. II, pp. 76-79. ${ }^{31}$ Carroll to O'Leary, April 23, 1879; Carroll to Devoy, Feb. 27, 1880; Richard McCloud to Devoy, Mar. 24, 1880; Circular from the Executive Committee of the Clan-naGael, April 19, 1880, Lomasney to Devoy, Dec. 24, 1880; Reynolds to Devoy, July 10, 1881, Devoy's Post Bag, Vol. I, pp. 430-31, 494-95, 501-02, 510, vol. II, pp. 26-27, 99.

32 Sullivan to Devoy, Sept. 4, 1880, Devoy's Post Bag, Vol. I. pp. 549-51. 
By the following spring the Clan Executive Committee was so disgusted at the inactivity of the home organization that they requested the I. R. B. replace two of its three members on the Revolutionary Directory with competent individuals. Under the present circumstances, it claimed, it was "unfair and useless to persist in keeping the organization in existence, and engaged in the accumulation of money, if nothing can be done with it by the inefficienoy of the I. R. B." 33

In contrast to its experience with the I. R. B. the Clan, for the most part, had satisfactory relations with Parnell and his constitutional nationalists. Parnell had returned to Ireland in March, 1880, barely in time to contest the general election. Nonetheless, the Home Rulers were quite successful; they captured about sixty seats, Parnell winning three. In late April Parnell succeeded in ousting Butt's moderate successor William Shaw as leader of the Home Rule Party. Thereafter, the Whig element gradually drifted out of the Irish party, and the Parnellites became the Home Rulers of the $1880^{\prime} \mathrm{s} .34$

During the first few months after the election the Parnellites had acted with restraint, giving the new Gladstone ministry a chance to do something constructive for Ire-

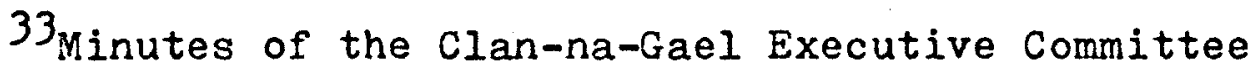
meeting, June 1, 1881, Devoy's Post Bag, Vol. II, pp. 76-79. ${ }^{34} \mathrm{C}$. C. $0^{\prime}$ Brien, Parne 11 and His Party, 1880-90 (Oxford, Clarendon Press, 1957), pp. 11-35; R. B. O'Brien, Parnell, Vol. I, pp. 214-25. 
1and. But when in August, 1880 the House of Lords threw out a moderate bill compensating evicted tenants, the Home Rulers renewed their active policy. Within Parliament they returned to their obstructive tactics, while in Ireland they began to make incendiary speeches. By their defense of Irish tenant farmers and their declarations for Irish self-government the Parnellites endeared themselves to Irish-American extremists 35 The Gladstone ministry, of course, viewed these developments quite differently. In November, it announced that Parnell and thirteen other Iand Leaguers would be prosecuted for conspiracy to prevent the payment of rents. But this action ended dismally when the jury failed to reach a decision. In January the government introduced a coercion bill suspending habeas corpus, and the Parnellites responded with obstructive tactics. On February 3, 1881, as Parliament debated the coercion bill. Irish M. P.'s learned about the imprisonment of Davitt. Infuriated, they created a great turmoil in the House of Commons and were ejected one by one for disobeying the Speaker's orders. Davitt and the more radical element in the League wanted the Home Rulers to withdraw permanently from the British Parliament and begin a No-Rent campaign. Since the situation in Ireland was quite tense -- agrarian outrages and other sporadic violence was the order of the day -- such a program could have led to scattered revolts throughout rural Ireland. Parnell, for

${ }^{35}$ C. C. 0'Brien, Parnell and His Party, pp. 49-55; R. B. O'Brien, Parnell, Vol. I, pp. 226-4I. 
this and other reasons, decided to take the more conservative course; he re-entered Parliament and refused to inaugurate a No-Rent campaign. 36

Some authorities on the period have viewed Parnell's refusal to secede from Parliament as an indication he was not committed to the more extreme phase of the New Departure. 37 But the truth is that in February, 1881, with the I. R. B. completely unprepared for a rebellion, the Clan was as much opposed as Parnell to any action that might set off an uprising. Since the formulation of the New Departure in 1879, one of the constant fears of the Clan had been that agrarian violence might lead to a premature rebellion. This, the Clan believed, would sound the death knell of the revolutionary movement, for the British would move in and crush it before it ever got off the ground. For example, in October, 1880, Devoy told his fellow Clansmen that "all our efforts should be directed to restraining the people in Ireland from any premature insurrectionary movement." 38 Similarly, in February, 1881, the Clan Executive Committee declared, "Our preparations are far from complete, and no

$$
{ }^{36} \mathrm{C} \text {. C. } 0^{\circ} \text { Brien, Parnell and His Party, pp. 55-64; }
$$

R. B. O'Brien, Parnell, Vol. I, pp. 249-87.

37 For example see C. C. O'Brien, Parnell and His Party, pp. 59-64; Tom Corfe, The Phoenix Park Pifurders: Conflict, Compromise and Tragedy in Ireland, 1829-1882 (London: Hodder and Stoughton, 1968), pp. 111-13. For a somewhat different point of view see Michael Hurst, Parnell and Irish Nationalism (Toronto: University of Toronto Press, 1908), p. 73. ${ }^{38}$ Circular from Devoy to the Clan-na-Gael camps, oct. 30, 1880, Devoy's Post Bag, Vol. II, pp. 12-13. 
action upon our part, public or private must tend to produce such a state of things as would enable the British Government to stamp out the organization at home. Such a catastrophy would blast Ireland's hope for many years to come."39 Consequently, Parnell's Clan-na-Gael "allies" were not particularly disappointed when he refused to withdraw from Parliament. Instead, the Clan continued to believe that the Irish leader would support a revolution at the opportune moment. In February, 1881 William M. Lomasney, a member of the Clan Executive from the Michigan district, after meeting with Parnell concluded that he was "eminently deserving of our support, and that he means to go as far as we do in pushing the business." 40 Some months later Henri Le Caron, the British spy, acting as a Clan envoy visited Parnell and reported that he was still firmly committed to the violent overthrow of the British government in Ireland. Parnell, of course, as always had practical reasons for assuring Irish-American extremists of his revoIutionary intentions. At this particular time he wanted them to put pressure on the I. R. B. to halt its opposition to the Iand League and the Irish Parliamentary Party. He

\section{${ }^{39}$ Circular from the Clan-na-Gael Executive Commi-} ttee to the Camps, Mar. 1, 1881, Special Commission, Vol. IV, p. 540. See also Devoy's Post Bag, Vol. II, pp. 29-32; Patrick Mahon to Carroll, April 13, 1879; Michael Boland to Devoy, Nov. 10, 1880; Lomasney to Devoy, Jan. 4, Mar. 31. 1881, Devoy's Post Bag, Vol. I, p. 426, Vol. II, pp. 13 , 31-32, 56-59; Gaelic-American, oct. 13, 1906.

${ }^{40}$ Lomasney to Devoy, Feb. 18, 1881, Devoy's Post Bag, Vol. II, pp. 39-40. 
was also upset by the fact that the Clan had instructed its camps to retain the money of Land League branches under their control. 41 Perhaps, Parnell was simply using the Clan for his own purposes and would never have supported a revolution. The truth, however, will never be known; the opportunity for a rebellion never arose to test his sincerity on the violent phase of the New Departure.

As Le Caron was returning from Europe in June, 1881, the Clan-na-Gael was busily making arrangements for its biennial convention to be held in Chicago that August. This convention proved to be a turning point for the Clan-na-Gael and brought Alexander Sullivan to the forefront in IrishAmerican affairs.

The nearly two hundred Clan delegates meeting in secret sessions at the Palmer House from August 3 to August 10 made several important decisions. First of all they reorganized the Executive Committee. Prior to the convention the Executive Body consisted of a chairman, secretary, treasurer, and representatives from the fifteen Clan districts. The members, however, considered this arrangement to be clumsy and ineffective. Moreover, the large number of mem-

\section{Devoy's Post Bag, Vol. II, pp. 80-88, 90-9l;} T. W. Beach (Henri Le Caron) to Devoy, June 18, I881 (two letters): Devoy to Beach, June 24, 1881; W. J. Hynes to Devoy, June 26, 1881, Devoy's Post Bag, Vol. II, pp. 8994: Beach, Twenty-Five Years in the Secret Service: The Recollections of a Spy (London: William Heinemann, 1892), pp. 172-81. The defense at the Times-Parnell Commission denied such discussions ever took place, but the evidence points in the other direction. Charles Russell, The Parnell Commission: The Opening Speech for the Defense (London: Hacmillan and Company, 1889), pp. 478-82. 
bers on the Executive Committee made it easier for secret information to leak out and get into the hands of British spies. The convention, therefore, decided to reduce it to five members. The various districts would continue to elect leaders, but these would no longer sit on the Executive body; they would be concerned merely about local matters. The streamlined Executive Committee could then deal with general policy without having to bother about the petty details of local administration. 42

Elected as Chairman of the new Executive Committee was Alexander Sullivan. The other members were Michael Boland of Louisville, Denis Feeley of Rochester, James S. Treacy of New York, and James Reynolds of New Haven, the outgoing chairman who had taken over after carroll had resigned in June, 1880.43

One of the first duties of the new ruling body was the selection of the three American members of the Revolutionary Directory. Prior to the convention the Clan delegates on the Revolutionary Directory had been Doctor Carroll, William Hynes, and Devoy. Devoy decided to step down for personal and financial reasons. Carroll and Hynes also tendered their resignations to give the new Executive Com-

42 Devoy, "Story of the Clan-na-Gael," Gaelic-American, Dec. 20, 1924; Beach, Twenty-Five Years, p. 191 . For an opinion on the need for a smaller and more tightly knit Executive Committee see John Fitzgerald to Devoy, July 3, 1881, Devoy's Post Bag, Vol. II, p. 96.

${ }^{43}$ Devoy, "Story of the Clan-na-Gael," Gaelic-American, Dec. 20, 1924. 
mittee a free hand, but indicated they would be willing to continue in their present positions. The Executive Committee, nonetheless, ignored Carroll and Hynes and, instead, selected three of their own -- Sullivan, Boland, and Feeley. These three individuals, later known as the Triangle, therefore, had control of the Executive Committee and the Revolutionary Directory. As we shall see in the next chapter, their policies eventually had disastrous effects on the Clan-na-Gael. 44

Besides altering the structure of the Executive Committee the convention also took up policy matters. There was considerable discussion about a future uprising in Ireland. The military committee recommended that "something definite should be laid down as to the time in which a rising might be expected to take place. We would suggest next year as being the centenary of the Irish volunteer movement, which culminated in the independence of our country, as a good one for work." Although the convention made no definite plans for a revolution, it indicated its sincerity to wage war in the near future by urging every camp to set up a special arms fund. Furthermore, while waiting for the day they could stage a revolution, many delegates favored carrying on dynamite attacks in reprisal "for the cruelties of a bloodthirsty enemy." While they opposed the reckless skirmishing tactics of some Irish-American extremists like Jeremiah O'Donovan Rossa, which brought ridicule 
on the Irish and endangered the lives of innocent civilians, the majority of delegates saw nothing wrong in well-planned attacks on citadels of British power. The convention, however, did not vote for a dynamite policy per se; it expressed support for an "active policy" and endorsed whatever action the Executive Committee decided to take. Later on, the Sullivan-dominated ruling body would interpret this as an approval for a dynamite campaign. 45

Besides dealing with revolutionary matters the convention also discussed the constitutional movements, the Iand League and the Irish Parliamentary Party. The delegates declared:

It is the sense of this convention that both branches of the S. E. [the Clan and I. R. B. delegates on the Revolutionary Directory] in so far as they can give their time to the work of revolution; and that if such bodies cannot give their approval to public movements that are intended to promote the political and social regeneration of Ireland, when they are supported by a large proportion of the Irish people, they will at least refrain from antagonizing them; and that members of the J.S. C. and $V . C$. [I. R. B, and the Clan-na-Gael] should not arbitrarily be prevented from exercising liberty of action in
regard to such movements. 46

Thus, despite the bad memories of the Buffalo convention, it was evident that the clan's policy toward the

45 Report of James Reynolds, Chairman of the Clan-naGael Executive Committee at the Chicago Convention, 1881, Report of the Clan-na-Gael Military Committee at the Chicago Convention, 1881, Special Commission, Vol. IV, pp. 580-83; Beach, Twenty-Five Years, pp. 187-89, 198-99. ${ }^{46}$ Cited in Special Commission, Vol. IV, pp. 582-83. 
Iand League would be one of friendly co-operation. But under Sullivan the Clan would even go further than this. At the Chicago Irish Race Convention in December, 1881 the Clan would make an all out effort to convince both factions of the Iand League in the United States to merge in a centralized Irish-American organization which would be secretly controlled by extremists.

Between the Clan convention in August and the Irish Race Convention the following December, a series of events occurred which dramatically altered the situation in IreIand. On August 22, 1881 the British Parliament gave approval to Gladstone's Land Act. Based on the principle of the famous "three F's" - fixity of tenure, fair rents established by land courts, and free sale -- this bill in effect created dual tenant and landlord ownership of the land. Despite its deficiencies -- it did not include leaseholders and those in arrears of rent -- it proved to be a major turning point in improving the lot of the Irish tenant farmer. Parnell's moderate supporters like the clergy wanted to accept the bill as an honest effort to solve the Irish land problem. But extremists like Davitt, favoring the complete abolition of landlordism, rejected the act. Parnell, caught in the middle, had to conciliate both sides. When the Irish Land League met in Dublin in September to consider its position on the new law, Parnell succeeded in steering the delegates on a moderate course. They decided to postpone judgement on the act. In the meantime they 
would bring certain test cases into the land courts to determine if tenants would receive a fair shake. Having placated his more conservative supporters, Parnell now had to pander to the extremists, most notably Ford who supplied a great deal of the Land League funds through the Irish World. Consequently, Parnell delivered a series of inflamatory speeches excoriating the British government. In October after a particularly incendiary address in Wexford, he was arrested under the provisions of the coercion act. A few days after his imprisonment, he and other incarcerated Irish leaders issued the No-Rent Manifesto urging tenants to withhold rents. Parnell once again became popular with Ford and his followers; they claimed that by issuing the Manifesto, Parnell had endorsed their No-Rent philosophy. The Clan-na-Gael and the conservatives, however, contended the Manifesto was meant simply as a tactical weapon to secure Irish demands for peasant proprietorship. 47

The No-Rent Manifesto actually had little practical effect, for the power of the Land League was declining rapidly. Shortly after Parnell's imprisonment the government suppressed the League as an illegal organization. Authorities broke up meetings, arrested local leaders, and confiscated records, thereby effectively destroying the

\section{R. B. O'Brien, Parnell, Vol. I, pp. 290-320; T. P.} O'Connor, Memoirs, Vol. I, pp. I77-79; O'Hara, Chief and Pribune, p. 198; C. C. O'Brien, Parnell and His Party, pp. 65-74; Brown, Irish-American Nationalism, pp. 113-15; Palmer, Land League Crisis, pp. 247-64, 282-98; F. S. I. Lyons, John Dillon (Chicago: University of Chicago Press, 1968), pp. 55-60. 
machinery the League might have used to implement its policies. The Ladies Iand League, established to take the place of the outlawed organization, proved a poor substitute in this regard. Furthermore, church opposition to the League over the No-Rent Manifesto -- it considered it communistic -weakened its hold on rural Ireland. But perhaps the most important factor in undermining the Land League's influence was the fact that the land courts were satisfactorily reducing the rents. To a large extent, the Iand Act had destroyed the raison d'etre of the League. Despite the efforts of the Ladies Land League, the movement was loosing much of its vitality. Agrarian outrages increased, but there was little organized mass protest as in the past. 48

With Parnell and his lieutenants in prison and the Land League disintegrating, Irish-American nationalists were understandably alarmed over the state of affairs in Ireland. In the fact of these increasing difficulties it was becoming evident that the various Irish-American factions had to lay aside their differences and unite in some common action to help the Irish at home. In Chicago John Finerty discussed the situation with three of the chief clansmen in the city -- William Hynes, President of the Irish-American Club, William Curran, President of the United Irish Societies, and Michael Ryan, county delegate of the Ancient Order of Hibernians -- and came to the conclusion that the best way to raise money and show the solidarity of Irish-Americans for

${ }^{48}$ Palmer, Land Leasue Crisis, pp. 298-307. 
Parnell, would be to hold a national convention of all Irish organizations in the United States. With the encouragement of the three above mentioned individuals Finerty wrote letters about the proposed convention to Ford and Collins, the leaders of the two rival Land League factions, and to John Boyle O'Reilly, editor of the Boston Pilot. Upon a favorable reply he traveled east to make the arrangements. After some negotiations, Collins, Ford, and $0^{\prime}$ Reilly, as well as three Irish envoys then touring the United States -- Timothy Healy, T. P. O'Connor, and Father Eugene Sheehy -- agreed to sign the call for a convention of all Irish groups in America to be held in Chicago from November 30 to December 2, 1881.49

While in the East Finerty also met with Devoy, who suggested that he consult Sullivan on the upcoming convention. Finerty, however, refused to do this, most likely because he was under the influence of Hynes who distrusted Sullivan. Hynes, no doubt, was still piqued over Sullivan's failure to re-appoint him to the Revolutionary Directory the previous August. Thus, ironically, the chief executive of the Clan-na-Gael was left in the dark about a convention planned to a large extent by Clansmen in his own city. 50 Though irritated he had not been consulted on the

${ }^{49}$ Chicago Citizen, Jan. 5, 1884; Devoy, "Ford Decisively Defeated in First Race Convention, "Gaelic-American, Sept. 29, 1923; T. P. O'Connor, Memoirs, Vol. I, pp. 206-13.

50 Devoy, "Ford Decisively Defeated in First Race Convention," Gaelic-American, Sept. 29, 1923. 
convention, Sullivan lost little time in deciding on a policy toward the upcoming gathering. On November 21, 1881, the Clan Executive sent circulars to the senior guardians of the various camps urging them to send delegates to the Irish Race Convention. In order to save money, it suggested that, if possible, Clansmen attend as representatives of other Irish groups of which they were also members. In contrast to the previous Land League conventions, it was evident that the Clan under Sullivan would try to pack this assembly to insure it would not be hostile to extremist interests. 51

Sullivan's aspirations of the Clan's dominating the Chicago Convention were largely fulfilled. Of the 845 delegates present, approximately 400 were members of the Clanna-Gael. The extremists, therefore, accounted for nearly half the delegates at the convention. Clan authorities, by their efforts to encourage attendance, could, no doubt, take credit for this fine turnout, but the location of the convention was also an important factor; Chicago and most of the Middle West, for that matter, was an extremist stronghold with little conservative influence. The importance of selecting Chicago as the convention site is demonstrated by the fact that Illinois had the largest number of delegates with 194. Other midwestern states also had far more repre-

${ }^{51}$ Circular from the Headquarters of Clan-na-Gael District K, Nov. 21, 1881, cited in Beach, Twenty-Five Years, p. 204; Circular from the Clan-na-Gael Executive Committee, Jan. 3, 1882, Special Commission, Vol. IV, p. 597. 
sentatives than their Irish populations would warrant, while New England and New York were under-represented. 52

The Clan-na-Gael was extremely well organized at the convention. Between sessions Clan delegates planned their strategy at secret caucuses. As a result of careful manipulation most of the key offices fell into the hands of extremists, John Finerty gave the opening address; Hynes served as temporary chairman; and Reverend George Betts, an Episcopalian priest from St. Louis, was chosen as permanent president of the convention. Since the Clan also secured control of the committee on resolutions, it succeeded in passing favorable resolutions. The convention strongly denounced English misrule in Ireland and pledged full support of Parnell's present policy. The delegates agreed to raise $\$ 250,000$ by February 1, 1882. In contrast to Buffalo, the Chicago convention did not condemn violence as a means of securing Irish independence. Instead, although the delegates did not explicitly endorse revolutionary methods -this would have been out of place at a supposedly constitutional gathering -- they promised to back the Irish at home "in every struggle against British rule." Furthermore, the Clan, along with the conservatives, defeated Ford's efforts to have the No-Rent Manifesto endorsed as a social doctrine. The Planifesto was approved, but only as a temporary weapon

52 Circular from the Clan-na-Gael Executive Committee, Jan. 3, 1882, Special Commission, Vol. IV, p. 597; Chicago Times, Dec. 2, 1881 . 
to wrench concessions from the British government. 53

The Clan-na-Gael, however, failed to achieve one of its chief goals -- the creation of a central Irish-American organization which it could secretly manipulate for its revolutionary interests. Antagonism between the conservatives and Ford precluded any kind of union between the two rival Land Leagues. Nonetheless, the Clan succeeded in getting Ford and the conservatives to agree to a proposal setting up a permanent committee of seven, which would serve as a link between the two leagues and investigate the possibilities of a united movement in the future. The clan captured this body, as it had other committees at the convention. The convention voted to give the chairman, Reverend Betts, the power to nominate the members of the committee. Being a faithful Clansman, the St. Louis clergyman named four extremists to the council: Sullivan and Boland, both of whom were members of the Clan Executive Committee, Doctor William Wallace of New York, and Andrew Brown of St. Louis. The three other members, Ford, Collins, and Judge Birdsall of Connecticut were not Clansmen, and thus lent an air of impartiality to the committee. 54

53 Irish Nation, Dec. 10, 1881; Chicago Times, Dec. 1, 2, 3, 1881; Devoy, "Ford Decisively Defeated in irst Race Convention," "How Union Was Effected at Chicago Convention," Gaelic-American, Sept. 29, Oct. 13, 1923; T. P. O'Connor, Niemoirs, Vol. I, pp. 213-14; T. M. Healy, Letters and Leaders of My Day, Vol. I, pp. 140-42.

54 Irish Nation, Dec. 10, 1881; Chicago Times, Dec. 3. 1881; Devoy, "Ford Decisively Defeated in First Race Convention," "How Union Was Effected at Chicago Convention," Gaelic-American, Sept. 29, Oct. 13, 1923. 
The Irish National Executive Committee, as the seven-man body was known, held its first meeting in December, 1881 in New York City. Boland was elected Chairman. Clan members argued that the committee should try to arrange a Iederation of all Irish-American societies in sympathy with the aims of the Land League, but Ford and Collins were no more amenable to entering any kind of confederation than they had been in Chicago. Sullivan also tried to strengthen the power of the Clan-dominated committee by urging that all donations to the special Anti-Coercion Fund established at the convention be sent to the Irish Land League Treasurer through Dennis $0^{\prime}$ Connor. O'Connor, who had served as treasurer for money collected at the convention, was treasurer of the Illinois State Iand League and a trusted friend of Sullivan. Once again, however, Ford and Collins opposed this. Instead, they suggested that contributors send their donations through any of the existing channels. 55 Despite this setback the Clan-na-Gael continued to work for a united Irish-American organization. It would not achieve this, however, until April, 1883.

Though it failed to unite the two rival Land Leagues under one banner, the Clan-na-Gael did manage to draw the official League closer to its orbit. In April, 1882, the American land League held its third annual convention in Washington. The conservatives held a numerical edge over the Clan as they had at Buffalo. The decision to hold the

$$
55 \text { Irish Nation, Dec. } 24,1881 .
$$


convention on the East coast no doubt proved important in this regard; the extremist-dominated Midwest sent few delegates. Illinois, for example, had no representatives. 56 But unlike at Buffalo, this time there was generally a spirit of co-operation between the conservatives and the Clan. The reason for the change in attitude could be traced to their common fear that with Parnell in prison the land movement in Ireland might fall into the hands of extremists, more concerned about social reforms like land nationalization than Irish self-government. They were particularly apprehensive that Patrick Egan, the Irish Land League Treasurer in Paris, seemed to consider Ford's social theories typical of Irish-American opinion. (Perhaps Egan had good reason for thinking this way, since by the end of April, 1882, Ford had sent more money to the Irish Land League than all other channels combined.) 57 John Boyle O'Reilly summed up the feelings of many conservatives and Clansmen when he claimed: "Egan is terribly unfitted for the mouthpiece of a country in travail. He thinks the Irish World is America." 58 In

\section{Irish Nation, April 15, 1882. \\ 57 Devoy, Land of Eire, p. 85; see Devoy's comments} on social reformers: Irish Nation, Mar. 11, April 15, 1882. Egan, however, denied he was not a thorough going nationalist, Egan to Devoy, Feb. 17, 1882, Devoy's Post Bag, Vol. II, pp. 107-108. By the end of April, 1882 the Irish World had transmitted $\$ 304,008$ to Egan compared to $\$ 169.263$ from Father Walsh, the central treasurer and $\$ 103.548$ from all other channels: Irish World, April 29, 1882.

58 J. B. O'Reilly to Devoy, Dec. 16, 1881, Devoy's Post Bage Vol. II, p. 104. 
fact some conservatives, particularly the clerical element, were so dissatisfied with the Land League's "communist" No-Rent Manifesto that they deserted the American Land League. In early 1882, for instance, the number of American Land League branches dropped from 900 to 500.59 Therefore, by April, 1882 conservatives realized they had better bury the hatchet with the Clan and demonstrate conclusively that Ford did not represent the majority of Irish-Americans. Perhaps in this way they could keep Egan and his colleagues on the straight path of Irish nationalism.

Consequently, the proceedings of the Washington Convention were quite favorable to the Clan-na-Gael. Collins declined to serve as President for another year and was replaced by James Mooney of Buffalo, a member of the Clan. John J. Hynes, another Buffalo Clansman, was elected Secretary. Furthermore, the convention adopted resolutions acceptable to extremists; unlike at Buffalo, the delegates did not denounce violence as a means of securing Irish independence. And finally, the convention gave a major boost to the Clan's pet project for a central Irish-American organization when it instructed the incoming officers "to confer at their earliest opportunity with the council of seven chosen at the Chicago Convention as to the feasibility

59 For example, Bishop Gilmour of Cleveland denounced the No-Rent campaign and excommunicated women belonging to the Ladies Land League. In Rochester Bishop McQuaid condemned the Chicago Convention for endorsing the No-Rent Manifesto. Irish Nation, Jan. 14, Feb. 11, 1882; Brown, IrishAmerican Nationalism, pp. 122-23. 
of uniting under one head all the Land League branches now organized in the United States."60 Devoy, now editor of the Irish Nation, was so delighted he urged that all funds be sent through Father Walsh, the central treasurer of the American Land League. 61 Some of the Clan-dominated branches, particularly those in the New York metropolitan area, followed Devoy's advice. 62 However, Sullivan's Chicago nationalists, fearing this would lessen their influence, continued to forward their money through Dennis O'Connor. 63

Sullivan, however, was not merely concerned about the manner in which Chicago sent its money to Ireland; he was far more interested in getting a slice of the funds already deposited with the Irish Land League Treasurer in

${ }^{60}$ Irish Nation, April 22, 1882 ; Irish-American, April 22, 1882; Irish World, April 29, 1882.

61 Irish Nation, April 22, 1882. 10,1882 .

62 Irish Nation, May 13, 1882; Irish-American, June

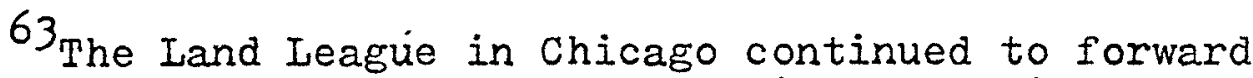
most of its money through $0^{\circ}$ Connor until the demise of the League in April, 1883. At the Philadelphia Convention in 1883 Father Walsh reported that from April 12, 1882 to April 25. 1883 the Land League in Illinois had sent him only $\$ 264$ (as compared with $\$ 19,893$ from New York and $\$ 15.722$ from Massachusetts). However, $0^{\prime}$ Connor reported that from the Irish Race Convention in December, 1881 until April 25, 1883 he had received a total of $\$ 36,505$. A good deal of this came from outside Illinois since some contributors, particularly Clansmen, to the Special Anti-Coercion Fund established at Chicago, sent their money to $0^{\prime}$ Connor. Sullivan, it will be remembered, had wanted $0^{\prime}$ Connor to be the sole Treasurer for the funds, but Collins and Ford would not agree. (see p. 152). The Third Annual Convention of the Irish National Land League of America and the rirst Convention of the Irish ivational League of America (Philadelphia, 1883), pp. 11, 38 . 
Paris. As we have mentioned previously, the Clan in the early part of 1882 had become quite skeptical about the League's value to the nationalist cause. Sullivan was beginning to fear the Land League funds would never be used to the benefit of the revolutionary cause. Consequently, convinced that Clan members had contributed substantially to the coffers of the Land League, he decided to go to Paris and ask Egan for a fair share of the money. The Clan could then use this directly for revolutionary purposes. If Egan refused to grant his request, Sullivan intended withdrawing support from the League. Without the Clan's backing, he believed, the American Land League would collapse. 64

On arriving in Paris, Sullivan had to carry on a great deal of tough bargaining with Egan. After some discussion, Egan agreed to hand over $\$ 50,000$ to the Clan chief; but Sullivan insisted he receive $\$ 100,000$. - half the total amount in the Land League treasury at that time -- and half of all future funds sent from the United States. Egan, however, refused to meet this demand, until finally Sullivan threatened to sever all connections between the Clan and the League, if his request was not granted. Faced with the possible destruction of the American money machine, Egan reluctantly acceeded to Sullivan's demand. 65

${ }^{64}$ Sullivan to Devoy, n. d. (sometime in early 1882), Devoy's Post Bag, Vol. II, pp. 113-15; Devoy, "Story of the Clan-na-Gael," Gaelic-American, Jan. 3, 1925.

65 Devoy, "Story of the Clan-na-Gael," Gaelic-American, Jan. 3, 1925. 
As later information showed, the funds Sullivan received never found their way into the Clan treasury. Instead, he used the money, himself, to speculate on the Chicago Board of Trade. At the coroner's inquest of the Cronin murder, evidence was introduced to show that on May 15, 1882, shortly after his return to the United States, Sullivan sent $\$ 100,000$ to his law firm in Chicago. This was then deposited in his bank account, and soon thereafter, nearly the same amount was withdrawn to pay a stockbroker. 66 Later on his enemies used these rather dubious transactions to bolster their argument that Sullivan was a corrupt politician, interested only in the Irish cause for his own self-agrandizement.

At about the same time Sullivan was returning to the United States, word reached Irish-America that Parnell had come to terms with Gladstone. By an informal agreement, commonly known as the Kilmainham Treaty, the government agreed to suspend coercion and amend the Land Act, so as to include leaseholders and those in arrears of rent. In return Parnell pledged to accept the amended Land Act as "a practical settlement of the land question," and to use his influence to quell agrarian crime rampant since the passage of the Coercion Act. Accordingly, the Irish leaders were released from Kilmainham Jail on May 2, 1882.67

66 Chicago Inter Ocean, June $6,7,1889$. 67 R. B. 0'Brien, Parnell, Vol. I, pp. 323-53; C. C. O'Brien, Parnell and His Party, pp. 75-79; O'Hara, Chief and Tribune, pp. 203-10. 
The Irish-American community received the news of the Kilmainham Treaty with mixed reactions. Ford's Irish World adherents considered Parnell's substantial acceptance of the Land Act a tragic betrayal of the Irish peasant. After Kilmainham Ford took little interest in the Land League and in october, 1882, dissolved his faction. ${ }^{68}$ In contrast to Ford, the conservatives welcomed the Kilmainham Treaty as a repudiation of violence and radical land theories. Though angered that Parnell was apparently turning his back on the New Departure, the Clan-na-Gael could, nonetheless, take some satisfaction in the agreement. For one thing, by dropping the No-Rent campaign, Parnell had clearly repudiated Ford's doctrine of land nationalization. And with Parnell out of prison there was less danger the nationalist movement would fall into the hands of socialists, as there had been during the period of his incarceration. Furthermore, if Devoy's attitude is any indication of Clan-naGael opinion, the Clan was pleased with Parnell's pledge to help curb agrarian crime. Devoy, of course, had always opposed such disorders for fear they would lead to a premature revolution. 69

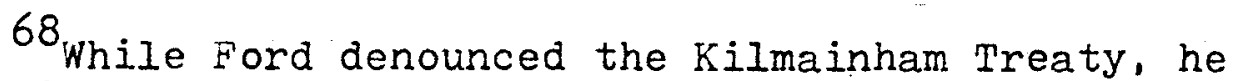
still insisted he regarded Parnell as leader of the Irish people. Irish World, June 17, Oct. 14, 21, 1882; Davitt, Fall of Feudalism, pp. 361-62.

${ }^{69}$ Davitt, Fall of Feudalism, pp. 361-66; Irish Nation, May 6, 13, 20, 27, June 3, 1882; Irish-American, Niay 13, 1882; Beach, Twenty-Five Years, p. 210. As early as March, 1882, Devoy advocated the halt of the No-Rent campaign because it might lead to war -- a war Ireland could never hope to win. Chicago Clansman John Finerty 
If, by making an agreement with Gladstone, Parnell had alienated some Clansmen who felt he was becoming too moderate, he regained a great deal of Irish-American sympathy in the aftermath of the Phoenix Park murders. On May 6, four days after Parnell's release from jail, a group of Irish extremists, known as the Invincibles, assassinated the newly appointed Irish Chief Secretary, Lord Frederick Cavendish, and the Undersecretary, Thomas Burke, in Phoenix Park, Dublin. Parnell and other Irish leaders denounced this senseless crime, but several English politicians blamed Parnell's policies for creating an atmosphere in which the murders could occur. In reaction to the English criticism heaped on Parnell. Irish-Americans tended all the more to rally behind him. 70

Parnell also picked up added support among Clan members as a result of his dispute with Davitt over the question of land nationalization. Davitt, released from prison shortly after Parnell, began criticizing the Irish leader for accepting the Land Act and surrendering on the No-Rent Manifesto. He also came out in favor of a modified version of Henry George's land nationalization program. In the eyes of the Clan-na-Gael it appeared that Davitt, like Ford, had drifted away from pure Irish nationalism toward humanitarian

bitterly criticized Devoy on this point. Irish Nation, Mar. 11, 18, April 1, 15, 1882; Irish World, Nov. 4, 1882; Diary of John Devoy, Devoy Papers, WSS 9620, National Iibrary of Ireland.

70 C. C. 0'Brien, Parnell and His Party, p. 82;

Corfe, The Phoenix Park Murders. 
reform. Consequently, in an effort to preserve the nationalist movement, Irish-American extremists supported Parnell in his fight with Davitt. 71

Parnell also increased his popularity with the Clanna-Gael when in October, 1882 he established the Irish National League to take the place of the Irish National Iand League. Unlike its predecessor the primary goal of the new organization was Irish self-government; land reform was only a secondary aim. Irish-American extremists naturally welcomed a constitutional movement which emphasized national goals instead of the subsidiary land issue, even though it did not demand total separation from Britain. ${ }^{72}$ As Sullivan had noted in early 1882, Irish-Americans were willing to support Home Rule not as the ultimate solution to the Irish question but as a step in the right direction. 73

\section{${ }^{71}$ Davitt, however, still maintained he was loyal to}

Parnel1. Brown, Irish-American Nationalism, pp. 125-30. Land nationalization was rejected by all major Irish-American newspapers except for the Irish World. For the editorial comments of the Irish-American, Irish Nation, Boston Pilot, and Chicago Citizen see summaries in Irish-American, June 24, 1882; Irish Nation, July 1, 1882. See also Davitt, Fall of Feudalism, pp. 346-80; D. B. Cashman, The life of Michael Davitt (Boston: Murphy and McCarthy, 1881). pp. 156-85; 0'Hara, Chief and Tribune, pp. 217-27; J. J. 0 'Kelly to Devoy, received ifiay 28, 1882, Devoy's Post Bag, Vol. II, pp. 121-22; Irish Nation, May 27 June 24, July $i$, 8, Aug. 12, 1882; Chicago Tribune, June 29, 1882.

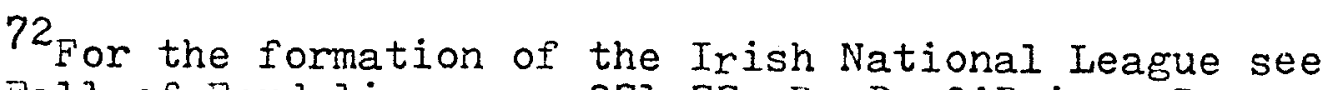
Davitt, Fall of Feudalism, pp. 371-77; R. B. O'Brien, Parnell, Vol. I, pp. 369-70; C. C. 0.Brien, Parnell and $\mathrm{His}$ party, pp. 126-33.

73 Irish Nation, Feb. 25, 1882. Similarly, one of the resolutions at the annual August 15 picnic of the Chicago Clan-na-Gael declared: "While yielding not even to the slightest extent our demand for an Irish Republic, we cor- 
Parnell's decision to replace the Land League with the Irish National League also gave new impetus to the Clan's project to establish a unified Irish-American movement. With the founding of the National League in Ireland it made sense to establish a similar organization in America to replace the Land League. The Clan hoped that this new body, by including all Irish societies in the United states, would fulfill its dream of a united Irish-America. As early as November, 1882 the Clan-na-Gael began demanding American Land League officials -- they did not have to worry about Ford's faction since he had dissolved it in October -call a convention to reorganize the present league along the lines of the Irish National League. 74 Accordingly, in March, 1883 James Mooney, President of the American Land League, joined his fellow Clansman, Michael Boland, Chairman of the Irish National Executive Committee, and Patrick Egan, former Land League Treasurer now residing in the United States, in issuing a call for a convention of all Irish

dially endorse the efforts of Parnell and others to secure for Ireland what is termed 'Home Rule,' because we regard every step in that direction as a means to the right end -the absolute independence of Ireland." Chicago Tribune, Aug. 16,1882 .

74 See Irish-American, Nov, 25, Dec. 2, 9, 1882, Jan. 13, 20, 1883: Irish Nation, Jan. 20, 27, 1883. In July, 1882 Davitt had suggested the formation of a federal organization of Irish groups throughout the world. The Clan-naGael. Ford, and Collins agreed to a modified version of Davitt's "Celtic Confederation," but the plan fell through when Parnell refused to give it any encouragement. Davitt, Speech, pp. 155-57, 161; Davitt, Fall of Feudalism, pp. 36768; Irish-American, July 16, 1882; Irish Nation, July 15, 1882; Irish World, July $22,1882$. 
societies to meet in Philadelphia on April 26, 1883 for the purpose of forming an Irish National League of America. Mooney also announced the Land League would hold a convention on the day prior to the other gathering; he intended it to merge with the new National League. 75

Thus, on April 25, 1883, 468 delegates gathered in Philadelphia for the third and final convention of the American Land League. After listening to routine speeches and Father Walsh's depressing report that the central treasury had received only a little over $\$ 60,000$ the previous year, the delegates got down to the main business at hand -- the fate of the Land League. The Clan-na-Gael and some conservatives wanted to dissolve the Land League upon the establishment of the National League. Land League branches would then become chapters in the new organization. But recalcitrant conservatives, fearing the Clan would dominate the new body, introduced a resolution to the effect that while the Land League should adopt the program of the Irish National League, it should continue to remain intact. The Clan, however, was ready for such a move. Andrew Brown, a st. Louis Clansman and Secretary of the Irish National Executive Committee, introduced what appeared to be a compromise substitute amendment. He proposed that the chairman appoint a committee of seven that would have the power "to declare the Land League adjourned sine die provided the convention complies with the report submitted and adopted here this eve- 
ning by a committee appointed to submit a plan of reorganization." A vigorous debate followed, but Brown's amendment passed 185 to 159. Since four of the seven men Mooney appointed were extremists, the Clan-na-Gael controlled this committee. It, of course, acted according to the Clan's interests and voted to disolve the Land League. 76

on the following day the 468 delegates from the Land League convention, as well as representatives from various Irish-American societies -- nationalist, fraternal, temperance, and literary -- met to establish the Irish National League of America. In all, 1,100 delegates attended. 77 The Clan-na-Gael, viewing this convention as the opportunity to fulfill its long awaited dream of a united Irish-America, was strongly represented. Prior to the gathering the Clan Executive Committee had sent circulars to the various camps urging them to send representatives. In order to save money, it suggested that, if possible, Clansmen attend as delegates of other Irish organizations of which they were also members. ${ }^{78}$ As a result Clansmen not only attended as representatives of their own camps, but also as delegates from branches of the Land League, the Ancient Order of Hibernians,

76 Third Annual Convention, pp. 3-24, 53; Irish World, May 5, 1883; Beach, Iwenty-Five Years, pp. 211-14.

77 Third Annual Convention, pp. 25, 35; Irish World, May $12,1883$.

${ }^{78}$ Circular from the Clan-na-Gael Executive Committee, n. d. (early 1883), Special Commission, Vol. IV, pp. 613-14; Sullivan to Devoy, Feb. 26, 1883, Devoy's Post Bag, Vol. II, pp. 181-82; Beach, Twenty-Eive Years, p. 211. 
and other societies. The Clan, to a far greater extent than the conservatives, took advantage of the fact that all IrishAmerican groups, not only the Land League branches, were represented at this convention. For example, the extremistdominated Illinois delegation swelled from sixteen members at the Land League Convention to fifty-one at the National League gathering. In contrast, the Massachusetts delegation, with a substantial conservative element, only increased from seventy-eight to ninety-five. 79

The Clan-na-Gael held secret caucuses to plan its strategy as it had at the Chicago Irish Race Convention, and, once again, its scheming paid off. The extremists captured the important committees on resolutions and organization, thus assuring the objectives of the new League would not be inimical to their cause. According to its constitution, the chief goals of the Irish National League of America were to aid Parnell "with moral and material aid in achieving self-government for Ireland; " educate the American people on the Irish question; promote Irish manufactures and boycott British goods; encourage the study of the language, history, art, and music of Ireland; and abolish all provincial and religious animosity among the Irish people. The Clan, however, steered away from explicitly endorsing violence, despite the protests of two Chicago hotheads, Finerty and Dunne. Such a public pronouncement would have only alienated the conservatives and hurt Parnell -- he claimed the British 
would have used it as a pretext to suppress the nationalist movement in Ireland. 80

Although in order to conciliate the conservatives and solidify Irish-America, the Clan-na-Gael permitted two important offices to fall into non-extremist hands (John Byrne of Cincinnati and Father Charles O'Reilly of Detroit were elected respectively as Vice-President and Treasurer), it largely gained control of the administration of the new organization. The Presidency went to Sullivan; he, thereby, became leader of both the constitutional and revolutionary Irish-American movements. Selected as the Clan nominee at a secret caucus, Sullivan encountered only slight conservative opposition and thus easily won the election. However, in order to be certain of conservative support, he refused to accept the Presidency until Father Thomas Conaty mounted the platform and pleaded with him to adhere to the wishes of the convention. Finally, Sullivan accepted the office, declaring that while he believed "a better selection could have been made. . I recognize the voice of the people is the voice of God." 81 In this instance, at least, the Clan was doing a good deal of the talking for the Lord.

The Clan-na-Gael also dominated the Executive Coun-

${ }^{80}$ Ibid., pp. 23-50; Diary of John Devoy, Devoy Papers, MSS 9820, National Iibrary of Ireland; Irish World, May 12, 1883; Beach, Twenty-Five Years, pp. 213-16.

81 Third Annual Convention, pp. 51-52, 55-56; Irish Nation, May 5, 1883; Devoy, "Long Drawn Out Comedy at Philadelphia Convention," Gaelic-American, Nov. 3, 1923; T. H. Ronayne to Devoy, April 19, 1883, Devoy's Post Bag, Vol. II, p. 192 . 
cil, the body responsible for the administration of the Ieague. The convention had decided the ultimate governing authority of the League should lay in the President, VicePresident, and a National Committee, consisting of one delegate from each of the thirty-two states and territories represented. But since this body was far too large to effectively run the League, the constitution stipulated that the National Committee was to select seven of its members to sit as an Executive Council. These individuals, along with the President, would handle the daily administration of the organization. The Clan, which probably held a majority of the seats on the National Committee, succeeded in electing at least five extremists to the seven-man council. 82 Thus, the National League was, in fact, secretly under the control of the Clan-na-Gael.

Sullivan and his fellow Clansmen on the Executive Council were well adept at playing the constitutional game. After the convention Sullivan embarked on a national speaking tour and wrote articles explaining the Irish question to the American people. The Chicago Clansman continually denied - and even he at times must have choked on his words -- that there was any connection between the National

82 Third Annual Convention, pp. 50-56. The five Clan-na-Gael members of the Executive Council were Doctor William Wallace (New York), James Reynolds (Connecticut), Michael V. Gannon (Iowa), J. G. Donnelly (Wisconsin), and John F. Armstrong (Georgia). The other two members were Father P. A. McKenna (Massachusetts) and Senator James G. Fair (Nevada). Father McKenna was a conservative; Senator Fair's affiliation is unknown. See also Beach, TwentyFive Years, p. 216. 
League and extremists. And, though he refused to denounce violence, he expressed the hope that the Irish could achieve self-government through peaceful methods. While he mouthed constitutional platitudes, however, Sullivan and his comrades were always on guard to insure the National League would not work against the Clan's interests. For example, in April, 1884, the extremist majority on the Executive Council quickly squashed a conservative member's motion denouncing the Irish-American dynamite attacks in England. 83 It was, of course, the Clan-na-Gael that was secretly behind the dynamite campaign.

During his term as President, Sullivan also had to tackle two problems not related directly to the Irish struggle. The first of these concerned the immigration of Irish paupers to the United States. This situation had become somewhat more acute when, in 1882, the British Parliament passed a law granting loans to Poor Law guardians to help them finance the emigration of destitute persons in their districts. The sight of these poverty-stricken individuals arriving in America was a source of shame to Irish-Americans striving for respectability. The National League convention in Philadelphia passed a resolution declaring the American government should not be required "to support paupers whose pauperism began under and is the result of English misgovernment." The delegates instructed the national officers to

\section{${ }^{83}$ Irish Nation, May $5,12,26$, Sept. 22, 1883;} Irish-American, Sept. 15, Dec. 8, 22, 1883, Viar. 8, May 3. 1884: Irish World, Dec. 15, 1883. 
urge the President to stop the entrance of such immigrants. Accordingly, in June, 1883, Sullivan led a delegation of Irish-Americans to discuss the problem with President Arthur. Soon thereafter, immigration officials began to enforce more stringentIy the provisions of the Immigration Act of 1882 in regard to paupers. 84

The second issue concerned the purchase of American land by British speculators. Irish-Americans feared that, if English absentee landlords continued to buy land in the Western states, America might develop some of the agrarian problems typical of Ireland. In April, 1884 the Executive Council of the National League, after investigating the practice of British "land grabbing" in various states and territories, decided to go before the Democratic and Republican national conventions and ask them to support legislation limiting land ownership by aliens. That summer Sullivan appeared before the platform committees of both national parties and convinced them to accept planks calling for restrictive legislation. In 1887 Congress passed a law prohibiting aliens (except those declaring their intention of becoming American citizens) from buying land in federal territories. Of course, this law and similar ones enacted in some states, were more the result of pressure from native Americans than the Irish. ${ }^{85}$

${ }^{84}$ Irish Nation, June 30, 1883; Brown, Irish-American Nationalism, pp. 156-57.

${ }^{85}$ Irish American, Aug. 11, 1883, May 3, 1884; Irish World. Aug. II, 1883, May 3, June 28, July 19, 1884; Chicago 
Sullivan, however, served only a little more than a year as President of the National League; at the next convention, held in Boston in August, 1884, he resigned so he could campaign freely for Blaine. Nonetheless, as leader of the Clan-na-Gael, Sullivan continued to have a powerful voice in the affairs of the National League, since the Clan still pulled the strings of the organization. At the Boston Convention the extremists once again won control of the Executive Council. Furthermore, Patrick Egan, now a Clansman and prosperous Nebraska miller, was chosen to succeed Sullivan as President. Despite their past differences, Sullivan and Egan had become close friends since the latter's arrival in the United States in the spring of 1883. There was little doubt Sullivan had left the National League in safe hands. 86

On the whole, Sullivan had been a competent President. He had undertaken a vigorous speaking tour in an effort to bring the Irish question before the American public and had made some headway toward solving the problems of pauper immigration and land ownership by aliens. It is true that when he left office the National League had only

Citizen, June 21, 1884; Chicago Times, June 4, July 9, 1884; Official Proceedings of the Republican National Convention, 1884 (Minneapolis: Charles W. Johnson, 1903), pp. 31, 33, 36, 93-94; Official Proceedings of the Democratic National Convention, 1884 (New York: Douglas 'Taylor's Democratic Printing House, 1884), pp. 74-76, 196; John Higham, Strangers in the Land: Patterns of American Nativism, 18601925 (New Brunswick: Rutgers University Press, 1955), p. 87. ${ }^{86}$ Irish-American, Aug. 16, 1884; Chicago Citizen, Aug. $16,1 \frac{1}{884}$. 
553 branches, nine less than the Land League had claimed at its demise in April, 1883. But this could be attributed to the relative lack of activity in Ireland, rather than to any deficiencies Sullivan might have had as a leader. 87

As Sullivan handed over the Presidency to Egan he must have taken some pleasure in the thought that the Clan was now firmly in control of the constitutional movement in Irish-America. Since becoming Chairman of the Clan Executive Committee in August, 1881, the Chicago lawyer had worked steadfastly to reverse the Clan's previous indecisive policy toward the American Iand League. Under Sullivan the Clan had made a concerted effort to capture the constitutional movement, and thus insure it would never be used to the detriment of the revolutionary cause. The Clan's hopes were fulfilled in April, 1883 with the establishment of the National League. For the present, Sullivan was content to use the National League for constitutional ends. He was more than willing to aid Parnell in his fight for some limited form of Irish self-government as a step in the right direction. But he also, no doubt, had dreams that in the future, when Ireland was prepared for a full-scale uprising, the National League would serve as a useful asset to the Clan. In the meantime, as leader of the Clan-na-Gael, Sullivan was engaged in carrying on a dynamite campaign in England. As we shall see, however, this would do far more damage to the Clan than to the British government.

87 Brown, Irish-American Nationalism, pp. 160-61. 


\section{A HOUSE DIVIDED}

The Clan's primary objective was, of course, to aid the I. R. B. in overthrowing British rule in Ireland. But the opportunity for an armed rebellion did not arise until 1916, almost a half century after the Clan had been founded. During these years some Clansmen were content simply to collect money and carefully prepare for the day they would be able to hoist the green flag over Dublin Castle. Others, however, were not so patient. While waiting for the moment to launch a full-scale rebellion, they believed it worthwhile to send dynamite expeditions across the Atlantic to terrorize British authorities.

One of the most famous advocates of dynamite was Jeremiah O'Donovan Rossa. Sentenced to penal servitude for Iife in 1865 for Fenian activities, Rossa was released from prison in 1870 on condition that he leave the United Kingdom. Arriving in the United States in 1871, he was active in Irish-American affairs throughout most of his life. Most prominent extremists, however, considered him rather irresponsible -- the Clan expelled him in 1880. This wild Irishman received his first opportunity for terrorism in 1876 when Patrick Ford permitted him to use the pages of the Irish World to establish a Skirmishing Fund aimed at financing guerrilla warfare against England. Iittle activity of this kind resulted, however, for in $1877 \mathrm{~F}$ ord turned over 
control of the fund to a Clan dominated board of trustees. These individuals, believing Irish energies should be devoted to preparations for a well planned uprising instead of sporadic terrorist attacks, failed to use the money in the manner Rossa had intended. But though he lost control of the fund, Rossa continued to espouse dynamite; during the 1880's he sponsored a few reckless expeditions. ${ }^{1}$

o'Donovan Rossa was by no means the only exponent of terrorism; many members of the Clan-na-Gael also favored the idea. For example, during the winter of 1880-81 several Clansmen, including the usually cautious Devoy, advocated some type of retaliatory measures to punish England for its policy of evictions and coercion. ${ }^{2}$ The Clan-na-Gael Executive Committee, in fact, voted money for limited terrorist attacks, but the I. R. B. vetoed the proposal on the grounds that such tactics might result in punitive actions against the Irish population in Britain. The Executive Committee agreed to follow the wishes of the I. R. B., claiming it had the right to decide "a question where their own lives and

$1_{\text {William } 0}$ Brien and Desmond Ryan (eds.), Devoy's Post Bag, 1871-1928 (Dublin: C. J. Fallon, 1948-53), Vol. I, pp. 4-5, 10-12, 141-42, 315-19, 501-02; Thomas W. Beach, Twenty-ive Years in the Secret Service: The Recollections of a Spy (London: William Heinemann, 1892), pp. 135-39, 193, 237-38; Thomas $N$ : Brown, Irish-American Nationalism, 1870-1890 (Philadelphia: J. B. Iippincott Co., 1966), pp. 69-73. Joseph P. O'Grady, "Irish-Americans and AngloAmerican Relations, 1880-1888" (Ph. D. Dissertation, University of Pennsylvania, 1965), pp. 170-74.

2 Beach, Twenty-Five Years, pp. 155-56; Lomasney to Devoy, Dec. 24, 1880, Mar. 31, 1881, Devoy's Post Bag. Vol. II, pp. 26-27, 56-59. 
liberties were at stake." 3

Despite the I. R. B.'s opposition many Clansmen continued to advocate terrorism. At the Chicago Convention in August, 1881 there was considerable sentiment in favor of dynamite. The Military Committee, while not endorsing some of Rossa's reckless skirmishing proposals -- he wanted to blow up passenger ships -- recommended the Clan take reprisals for "the cruelties of a bloodthirsty enemy." The convention followed this advice and voted in favor of an "active policy" (for security reasons the word "dynamite" was not used). 4

At first the new Executive Committee headed by Sullivan followed the position of its predecessor; it favored retaliatory measures but refused to undertake them without the sanction of the I. R. B. 5 By the latter part of 1882 , however, the Executive Committee decided to reverse its policy and wage a dynamite campaign even though the Irish leaders still continued to oppose the idea. The reasons for this change are not difficult to uncover. In the sum-

3 Report of James Reynolds, Chairman of the Clan-naGael Executive Committee at the Clan-na-Gael Convention, 1881, Special Commission Act, 1888, Reprint of the Shorthand Notes of the Speeches, Proceedings, and Svidence Taken Before the Commissioners (London: H.M.S.0., 1890), Vol. IV, pp. 579$8 I$.

4 Report of James Reynolds, Chairman of the Clan-naGael Executive Committee at the Clan-na-Gael Convention, 1881. Report of the Clan-na-Gael Military Committee at the Clan-na-Gael Convention, 1881, Special Commission, Vol. IV, pp. 580-83; Beach, Twenty-Five Years, pp. 187-89, 198-99.

${ }^{5}$ Circular from the Clan-na-Gael Executive Committee, sept. 1, 1881, Special Commission, Vol. IV, pp. 589-92. 
mer of 1881 Clansmen still hoped that, despite the total ineptitude of the I. R. B., an uprising would take place in 1882, the centenary of the Volunteer movement. But by the autumn of 1882 it was evident the I. R. B. would not be able to launch a rebellion that year, nor did it seem likely it could carry off one within the foreseeable future. ${ }^{6}$ sullivan could have continued, of course, to collect money and supply the I. R. B. with arms, while patiently waiting for some distant time to wage a revolution. But this had one serious pitfall -- it would be difficult to keep frustrated rank and file clansmen in the organization with such an inactive policy. It was likely they would begin flocking to more militant Irish-American groups like Rossa's United Irishmen, which had been sending dynamiters across to England since 1881. Therefore, Sullivan, who as early as September, 1880 had advocated the Clan should sever its ties with the I. R. B. if it did not change its leadership, decided to conduct a dynamite campaign without the approval of the Irish chiefs. ${ }^{7}$ Besides keeping bloodthirsty Clansmen content,

6 For the anemic condition of the I. R. B. in the autumn of 1882, see James J. O'Kelly to Devoy, Sept. 21 , 1881, oct. 24, 1882, Devoy's Post Bag, pp. 140-43, 155-57.

7 For the demand among Irish-American extremists for some type of activity see James McDermott to Devoy, Sept. 16. 1882; Joseph Cromien to Fatrick Ford, Oct. 11, 1882, John J. Power to Devoy, Feb. 26, 1883; John Breslin to Devoy, April 2, 1883, Devoy's Post Bag, Vol. II, pp. 13840, 147-49, 181, 186. A few years before Devoy and Carrol1, later bitter critics of the dynamite campaign, had admitted that continued inactivity on the Clan's part would result in loss of members. $0^{\circ}$ Carroll to $0^{\prime}$ Leary, April 23, 1879, Devoy's Post Bag, Vol. I, pp. 430-31; Beach's 
Sullivan, no doubt, hoped the terrorist program might force the Iiberal government to make some concessions on the issue of Home Rule. Irish-Americans had not forgotten Gladstone's earlier statement that the Fenians had been responsible for spurring the British to enact certain reforms in Ireland. 8

Consequently, in the autumn of 1882 the Clan began to make preparations for the dynamite campaign. Sullivan, Boland, and Feeley, as members of the Revolutionary Directory, submitted requests for money to the Executive Committee, but without consulting their three Irish colleagues, as they were required to do according to the 1877 agreement. The funds were granted without any trouble since Sullivan and his two cronies made up the majority of the Executive Committee. The other two members of the committee also approved the requisitions, but did so believing the entire six members of the Revolutionary Directory, not merely the three Americans, supported the dynamite campaign. 9

testimony, Special Commission, Vol. IV, p. 524; Beach, Twenty-Five Years, p. 156, 254; Circular from the Clan-na-Gael Executive Committee, Sept. 16, 1883, Special Commission, Vol. IV, pp. 626-27. For Sullivan's attitude to the I. R.B. in 1880 see Sullivan to Devoy, Sept. 4, 1880, Devoy's Post Bag, Vol. I, pp. 549-5I.

${ }^{8}$ See the Circular from the Clan-na-Gael Executive Committee, December, 1885, Beach, Twenty-Five Years, pp. 24647.

9Devoy, "How the First Split in the Clan-na-Gael Originated," "Story of the Clan-na-Gael," Gaelic-American, Nov. 17, 1923, Dec. 20, 1924; Beach, Twenty-ive Years, pp. $217,238-39 ;$ Beach's testimony, Special Commission, Vol. IV, p. 628. For the Executive Committee's request for special funds and volunteers for the dynamite campaign see Circulars from the Clan-na-Gael Executive Committee, Oct. 1882, Mar. 30, 1883, Special Commission, Vol. IV, pp. 607-10, 612-13. 
The first terrorist attack under clan auspices occurred on March 15, 1883 when an explosion went off in the offices of the Local Government Board in London, causing some property damage but no loss of human life. That same day Clan dynamiters also planted a bomb at the London Times printing office, but it failed to explode. ${ }^{10}$ The British government reacted quickly by passing a new and more stringent explosives law. ${ }^{11}$ But this measure failed to stop the Clan's campaign. The following October dynamiters set off an explosion in the Iondon Underground Railway, causing damage to a number of trains and severely injuring several persons. ${ }^{12}$ In 1884 there were still more attacks. In February, Clansmen blasted Victoria Railway station; on May 30 , they dynamited Scotland Yard and several buildings in Saint James Square; and in December they staged an unsuccessful attempt to blow up London Bridge. ${ }^{13}$ But the most ambitious

Sullivan also asked the trustees of the National Fund (formerly known as the Skirmishing Fund) for $\$ 25,000$, perhaps for dynamite. Sullivan to ?, July 25, 1882, Sullivan to Devoy, Nov. 15, 22, 1882, Devoy's Post Bag, Vol. II, pp. 129, $158-60$.

10 Irish World, Mar. 31, 1883; 0'Grady, "Irish-Americans and Anglo-American Relations, 1880-88," pp. 181-82; John T. McEnnis, The Clan-na-Gael and the Murder of Doctor Cronin (Chicago: F.J. Schulte and J.W. Iliff, 1889), pp. 57 .

11 Irish World, April 21, 1883.

12 Beach, Twenty-Five Years, p. 242; McEnnis, The Clan-na-Gael, pp. 60-61; 0.Grady, "Irish-Americans and AngloAmerican Relations, 1880-88," pp. 195-96.

${ }^{13}$ Irish World, June 14, Dec. 27, 1884; Beach, TwentyFive Years, p. 242; HcEnnis, The Clan-na-Gael, pp. 60-61; O'Grady, "Irish-Americans and AngIo-American Relations, 1880 88," pp. 196-200. 
attack occurred on January 25, 1885 when bombs exploded in the Tower of London, Westminster Hall, and the House of Commons. Fortunately, in the latter case Parliament was not in session and no one was killed. ${ }^{14}$ The Clan conducted a few more minor attacks that year, but in December it halted its activities, so as not to hinder Parnell's campaign for Home Rule. 15

From an extremist's point of view the dynamite war was a disaster. Many dynamiters bungled their missions; several bombs never exploded, while those that did had little damage effect. And in one case -- the explosion under London Bridge -- three conspirators, including the Fenian hero William Mackey Lomasney, were blown to bits by their own dynamite. ${ }^{16}$ Furthermore, though some dynamiters escaped, eighteen of them were sent to prison, eleven for life. 17

${ }^{14}$ Irish World, Feb. 7, 14, 21, 1885; Beach, TwentyFive Years, p. 242; McEnnis, The Clan-na-Gael, pp. 60-6I; O'Grady, "Irish-Americans and Anglo-American Relations, 188088 ," pp. 200-201.

15 Circular from tine Clan-na-Gael Executive Committee, December, 1885. Beach, Twenty-Five Years, pp. 246-47.

${ }^{16}$ Devoy's Post Bag, Vol. II, pp. 4-10; Beach, Twenty-Five Years: p. 243; Mark F. Ryan, Fenian Memorjes (DubIin: M. H. Gill and Son, 1946), pp. 118-19; Chicago Citizen, May 1, 1886.

17 Based on a table from official British sources reprinted in Henry $\mathbb{M}$. Hunt, The Crime of the Century or the Assassination of Dr. Patrick Henry Cronin (Chicago: F.J. Schulte and J.W. IIiff, 1889), pp. 66-67 and MicEnnis, The Clan-na-Gael, pp. 58-59. The table lists thirty-two dynamiters imprisoned between Nay, 1881 and November, 1885. Of these one was released immediately after his conviction and two others died. In calculating the number of Clan-sponsored dynamiters I have excluded those convicted for outrages that 
Oddly enough, the majority of those imprisoned had not been directly involved in any of the actual explosions; British authorities had arrested them before they had a chance to practice their peculiar art. For instance, in June, 1883 Doctor Thomas Gallagher, a mild-mannered Brooklyn physician, and three comrades were sent to prison for manufacturing nitroglycerine in Birmingham and transporting it to an English exhibition in Galway. ${ }^{18}$ Similarly, a year later John Daly, later Lord Mayor of Limerick, and an accomplice were convicted of illegal possession of nitroglycerine. ${ }^{19}$ In none of these cases were the individuals arrested for setting off explosions. The reason they and others had been arrested prior to their participation in actual attacks was that British spies and Scotland Yard detectives had kept a close watch on their movements on both sides of the Atlantic. Spies like "Red Jim" McDermott and informers like James Lynch proved to be valuable assets in this regard. In fact,

took place prior to the inauguration of the Clan's campaign in March, 1883. It is also possible, however, that a few of those convicted for crimes occurring after Warch, 1883 were not Clansmen, but members of Rossa's United Irishmen or some other group. Le Caron, it should be noted, claimed that twenty-five men were imprisoned as a result of the dynamite campaign. Beach, Twenty-Five Years, p. 247.

${ }^{18}$ Irish Nation, April 14, 21, June 30, 1883; IrishAmerican, April 14, 1883; Irish World, April 21, May 5, 1883; McEnnis, The Clan-na-Gael, p. 58; Ryan, Eenian Memories, pp. 108-10; Beach, Twenty-Five Years, pp. 200-01, 240-42.

19 Irish World, April 26, May 24, 31, June 14, Aug. 16, 1884; Devoy's Post Bag, Vol. II, pp. 242-43; McEnnis, The Clan-na-Gael, p. 58; Ryan, Fenian Nemories, pp. 114-17; Beach, Twenty-itive Years, pp. 243-44. 
in some instances there was evidence indicating British spies had planted incriminating evidence on dynamiters in order to secure their convictions. 20

Later on Sullivan's enemies in the Clan-na-Gael claimed he had discussed the dynamite campaign with the British spy Le Caron and was, therefore, responsible for handing over information that led to the arrest and conviction of some of the conspirators. This allegation was false, however, for although Sullivan did confide in Le Caron, believing he was a devoted revolutionary, the information he gave him was only of the most general kind; Le Caron certainly learned nothing about the details of the various dynamite plots. Such facts were received from spies like McDermott with whom Sullivan had no contact. And in some cases the dynamiters helped to give themselves away by talking too freely about their activities. 21 But if sullivan was

20 Irish World, May 5, Aug. 25, Sept. 1, 8, 15, 22, 1883, oct. 18, 1890; Devoy's Post Bag, VoI. II, pp. 202-04, 242-43; John D. McCarthy to Rossa, Sept. 9, 1883; P. S. Cassidy to Devoy, Sept. 12, 1883; Suliivan to Devoy, Sept. 18, 1883;. McCarthy to Rossa, Sept. 21, 1883; John Daly to Devoy, no date (1884); P. O'Brien to Devoy, April 27, 1884 , Devoy's Post Bas, Vol. II, pp. 204-10, 243-44, 246; McEnnis, The Clan-na-iael, pp. 56, 63-64, 71-75; Ryan, Fenian Memories, pp. 108-10, 114-17; Beach, Twenty-Five Years, pp. 230. 240-42; Michael Davitt, The Fall of Feudalism in Ireland (New York: Harper, 1904), pp. 427-43; 0'Grady, "Irish-Americans and Anglo-American Relations, 1880-88," p. 187.

21 Robert Anderson, Sidelights on the Home Rule Movement (London: J. Murray, 1906), pp. 150-51; NcEnnis, The Clan-na-Gael, p. 231; Beach, Twenty-Pive Years, p. 217; Le Caron's testimony, Special Commission, Vol. IV, p. 628; Irish-American, April 24, 1885; Cronin Committee, Open Letter to Patrick Ford, Chicago Inter Ocean, July 17, 1889; Testimony of Luke Dillon before the Coroner's Inquest on the Cronin Wurder, Chicago Inter Ocean, June 8, 1889. 
not responsible for exposing the dynamiters, he and his cronies were guilty of grave mismanagement. Evidence introduced at the Clan-na-Gael trial in 1888 showed that in some instances the agents whom the Executive Committee had appointed to supply the conspirators with the necessary living and operating expenses, had failed to do so. As a result some terrorists were left stranded in England and had to make their way back to the United States under the most trying circumstances. 22 This was certainly not the way to run an efficient revolutionary organization.

Despite its shortcomings, most Irish-American extremists applauded the dynamite campaign. Ford's Irish World took great delight in every blast, declaring that dynamite was the only means of retaliation the Irish had against a tyrannical power. ${ }^{23}$ Similarly, the Irish newspapers in Chicago-- the Citizen, the Western Catholic, and the A. O.H. Emerald --supported the terrorist attacks. The Emerald claimed that "a few charges of dynamite carefully applied would have more effect in terrorizing the hardened old harridan than all the soul stirring appeals ever made by Irish eloquence to English feeling." 24 such sentiments were per-

22 Devoy, "Story of the Clan-na-Gael," GaelicAmerican, Feb. 7, 1925, McCahey-Cronin Minority Report and Cronin's Notes on the Testimony at the Clan-na-Gael Trial, 1888, Hunt, The Crime of the Century, pp. 87-100.

23 For example see the Irish World, Mar. 31,1883 , June $14,21,1884$.

${ }^{24}$ Chicago A. O. H. Emerald, cited in Irish World Jan. 12, 1884. See also Chicaso Citizen, June 7, 1884, 
haps only natural for the American Irish; they had emigrated from a land with a tradition of agrarian crime and lived in a nation where violence was the order of the day. In contrast to most extremists, conservative IrishAmericans denounced the dynamite campaign; they viewed it as immoral and a blow to Irish claims for respectability. Similarly, most Americans of non-Irish ancestry deplored terrorist attacks that seemed to serve no useful purpose and endangered innocent lives. 25 For example, after the explosion in the House of Commons, the United States Senate, usually pro-Irish and anti-British in tone, passed by a vote of sixty-one to one a resolution condemning dynamite attacks. 26 And in 1887, President Cleveland sent the Phelps Extradition Treaty covering dynamiters to the Senate for approval. In this instance, however, Irish pressure blocked its passage. 27

The dynamite campaign was also strongly denounced on the other side of the Atlantic. Parnell and Davitt condemned it as injurious to the Irish cause. ${ }^{28}$ Traditional

Jan. 31, 1885; Chicago Western Catholic, cited in Irish World, April 7,1883 . For other extremist opinion see letters to editor, Irish vorld, June 16, July 16, 1883.

25 Irish-American, Nar. 24, 1883; Irish World, Feb. 7, 1885. For the attitude of various American newspapers see Irish World, June 14, 1884.

26 Chicago Citizen, Jan. 31, 1885.

27 Florence Gibson, The Attitude of the New York Irish toward State and National Affairs, 1848-1892 (New York: Columbia University Press, 1951), pp. 401-03, 426.

28 Irish-American, Jan. 12, 1884; R. B. 0'Brien, The 
revolutionaries like James Stephens and John O'Leary declared it was immoral. 29 British conservatives also denounced the attacks, but more importantly it appears the dynamite campaign contributed to the growing belief among some Liberals that the Irish were an irresponsible people incapable of self-government. As a result of this attitude several Iiberals, including Chamberlain and Bright, broke with Gladstone on the issue of Home Rule. Furthermore, Irish-American terrorism seems to have cooled the English laboring classes toward the concept of Irish self-government; in the election of 1886 they voted for the anti-Home Rule coalition of Conservatives and Iiberal Unionists. 30

The dynamite campaign, however, did more than possibly injure the Home Rule movement; it also contributed in causing a deep and bitter split in the Clan-na-Gael. As we have mentioned previously, when Sullivan inaugurated the dynamite campaign, he had hidden the fact that the I. R. B. did not approve. While he realized the majority of Clansmen would still have supported his decision, he also knew

Life of Charles Stewart Parnell (London: Smith, Elder, and Co., 1899), Vol. II, p. 30; Davitt, Fall of Feudalism, p. 427. For the reaction of the Irish and English press to the dynamite campaign see editorial reprinted in Irish World, June $21,1884$.

29 Irish World, May 3, 1884; Desmond Ryan, The Phoenix Flame: A Study of Penianism and John Devoy (London: A. Barker, 1937), pp. 218-19; Viarcus Bourke, John O'Leary: A Study in Irish Separatism (Tralee, Co. Kerry: Anvil Books, 1967), pp. $144-45$.

${ }^{30}$ Brown, "Irish-American Nationalism, 1848-1890" (Ph. D. Dissertation, Harvard University, 1956), pp. 31518. 
there were some who would oppose any policy unsanctioned by the I. R. B. Therefore, if he hoped to continue the terrorist program without interference, it was important that he keep this latter group in the dark as much as possible about the Clan's actual relationship with the $I$. $R$. B.

At the Philadelphia Convention of the Irish National League in April, 1883 the Clan-na-Gael delegates held their own secret meetings to discuss revolutionary matters. Since it had been discovered that the British Secret Service had received vital information about the previous Clan-na-Gael convention in Chicago, the delegates at Philadelphia, including Sullivan's future enemies, passed a resolution recommending the Executive Committee ask the camps to approve an amendment designed to make it more difficult for British spies to gain entrance to a national convention. The amendment proposed that in the future the camps would send delegates to district assemblies instead of the national convention. These assemblies, in turn, would choose two delegates each for the national gathering. This would reduce the number of delegates at the national convention from about four hundred to thirty, and thus lessen the chances of secret information leaking out. This amendment, as well as another one postponing the 1883 convention until 1884, was quickly approved by the majority of camps. Sullivan gained two important benefits from these changes. The decision to postpone the convention assured him of another full year in office; he could, therefore, continue the dynamite cam- 
paign without having to explain matters to a national gathering of Clansmen. Secondly, since the new system of selecting delegates meant that each district, no matter what its membership, would send two representatives, the Western districts with far fewer camps than those in the East, significantly increased their strength. This aided Sullivan since most of his loyal followers were in the West. 31

The various district conventions met in early 1884. By careful manipulation Sullivan's supporters succeeded in electing a majority of the twenty-seven delegates chosen to attend the national convention in Boston that August. (It was held about the same time as the Irish National League Convention.) Furthermore, if we are to believe Devoy, Sullivan increased his influence in Boston by having Boland and himself appointed as proxies from an imaginary district in Australia and by failing to notify a couple of "opposition" delegates of the time and place of the convention. 32

Since the majority of delegates gathered in Boston were admirers of Sullivan, he had little difficulty in con-

${ }^{31}$ Diary of John Devoy, Devoy Papers, MSS 9819, National Iibrary of Ireland; Circulars from the Executive Committee of the Clan-na-Gael, May 12, 1883(2), Sept. 16, 1883, Special Commission, Vol. IV, pp. 652-58; Devoy, "Long Drawn Out Comedy at Philadelphia Convention," "Clan-na-Gael Convention in Boston Split the Organization," Gaelic-American, Nov. 3, 10, 1923; Beach, Twenty-Five Years, pp. 218-19.

32 McCahey-Cronin Minority Report on the Clan-na-Gael Trial, 1888, Chicaso Inter Ocean, May 27, 1889; Devoy, "Clanna-Gael Convention in Boston Split the Organization," "Story of the Clan-na-Gael." Gaelic American, Nov. 10, 1923, Jan. 17. 1925. 
trolling the convention. First of all, the assembly changed the constitution, reducing the Executive Committee from a body of five to three. Although the results of the election were supposedly secret, most Clansmen soon learned that Sullivan, Boland, and Feeley were the three members of the new Executive Committee -- it was known as the Triangle since all its official communications were signed with a " $\triangle$ ". This triumvirate thus gained complete control over Clan affairs. 33

Sullivan and his two colleagues also carefully concealed their financial affairs of the past three years. The duty of examining the Clan's accounts fell to the Financial Committee and the Foreign Relations Committee. But Sullivan's partisans comprised the majority on both of these committees. Not surprisingly, they found all the accounts in order. In their report they stated that for the past three years the Clan had received $\$ 253,000$ and had spent $\$ 266,000$, claiming the difference was made up from a secret source. But James Reynolds, the Treasurer from 1880 to 1884, contended later that instead of having a deficit of $\$ 13,000$, the Clan actually had a surplus of $\$ 6,000$. Furthermore, the report asserted that the Executive Committee had given $\$ 128,000$ to the Revolutionary Directory and

33 Constitution of the U.S. [Clan-na-Gael], 1884 , Special Commission, Vol. V., pp. 103-1l; Devoy, "Clan-naGael Convention in Boston Split the Organization," "Story of the Clan-na-Gael," Gaelic-American, Nov. 10, 1923. Dec. 13. 1924. 
$\$ 75,000$ to the I. R. B. But a later investigation showed that some $\$ 40,000$ spent for rifles had been listed twice -as part of both the $\$ 128,000$ and $\$ 75,000$. Thus, there was no account of $\$ 40,000$. And since Sullivan and Boland failed to notify the I. R. B. envoy, John O'Connor, about the convention, there was no one present from Ireland to dispute the figures charged to the I. R. B. At best Sullivan, Boland, and Feeley were poor accountants, at worst they were thieves. 34

As soon as the proceedings of the "secret" convention leaked out, Sullivan began to encounter opposition from Devoy and other New York Clansmen. Devoy, no doubt, was infuriated over Sullivan's decision to sever relations with the I. R. B. and to continue a dynamite campaign that had sent several dedicated nationalists to a living death in British prisons. Furthermore, he was angry over the apparent discrepancies in the financial transactions of the Executive Committee. But there also appears to have been other and more personal reasons for Devoy's dislike of Sullivan. First of all, he was probably disappointed that the Executive Committee or Revolutionary Directory had failed to provide financial aid for his Irish Nation, a newspaper with chronic circulation problems. Some Clansmen favored giving the Irish Nation monetary assistance since it supported the

34 McCahey-Cronin Minority Report on the Clan-naGael Trial, 1888, Chicago Inter Ocean, May 27, 1889; Devoy, "Clan-na-Gael Convention in Boston Split the Organization," "Story of the Clan-na-Gael," Gaelic-American, iNov. 10, 1923. Feb. 7, 1925. 
Clan's revolutionary principles, but Sullivan, perhaps feeling Devoy's constant personal attacks on other nationalists like Rossa and Davitt hurt more than helped the Irish cause, never made any attempt to aid the newspaper. 35 Moreover, to make matters worse, Devoy claimed that during the presidential campaign of 1884 the Republican party had given Sullivan money to aid the pro-Blaine Irish Nation, but that he had failed to turn it over to Devoy. 36 Besides these difficulties, Devoy probably also resented Sullivan for using the Irish cause to further his own political career. Devoy, the pure revolutionary, could never understand the political ambitions of Irish-Americans. 37 Finally, it is possible the New York Irishman was angered over the fact that the Boston Convention had failed to appoint him to either the Executive Committee or the Revolutionary Directory. 38

35 Sullivan to Devoy, June 30 , July 14 , Sept. 2,6 , 1882, Sept. 3, 18, 1883; Bresl in to Devoy, April 18, 1883; 0 'Leary to Devoy, April 18, 1883; Thomas H. Ronayne to Devoy, Sept. 8, 1883, Devoy's Post Bag, Vol. II, pp. 126, 128-29, $131-34,190-92,201-02,207$. Sullivan at one time had Irish Nation stock but returned it in March, 1884, claiming he had been accused of opposing Finerty's Citizen because he was an Irish Nation stockholder. Sullivan to Devoy, March 25, 1884, Devoy's Post Bag, Vol. II, pp. 239-40.

${ }^{36}$ Sullivan denied these charges. Sullivan to Devoy, Nov. 4, 1884, April 7, 1885, Devoy's Post Bag, Vol. II, pp. $257-58,262-64$.

37 See Devoy, "Inside Story of the Blaine Campaign in 1884," "Irish Place Hunters, Not Burchard Caused Blaine's Defeat," Gaelic-American, Dec. 1, 8, 1923.

38 Another possible reason for Devoy's dislike of Sullivan may have been his feeling that the Executive Committee had not done all that it could to clear him of certain unknown charges. Because of this Devoy had contemplated re- 
Whatever his motives, Devoy and other New York nationalists, most notably John Breslin and James Pallas, began to mount a concerted attack against the Priangle. In December, 1884 the New York District held a convention and passed resolutions protesting the high-handed proceedings of the Boston Convention and the decision to cut off ties with the I. R. B. Breslin and Pallas sent copies of these charges to Clan camps all across the country. The Triangle, now technically headed by Boland (because of hostile criticism Sullivan had resigned from the Executive Committee on November 11, 1884 and from the Clan on April 9, 1885, but he was still the power behind the throne) denounced the charges as lies inspired by British agents. It also declared in a threatening tone that any Clansmen supporting the resolutions was "as infamous as Carey and deserves the same fate" (James Carey, the informer in the Phoenix Park murders case, was assassinated by an Irish nationalist in 1884). The Triangle suspended any camp endorsing the New York resolutions; the majority of these were in the East, particularly in the New York metropolitan area, but there were some in cities Iike St. Paul and Des Moines. 39

signing from the Clan in April, 1884. Devoy to ?, April 15, 1884, Devoy's Post Bag, Vol. II, p. 240.

39Diary of John Devoy, Devoy Papers, MSS 9819, National Library of Ireland; Devoy, "How the First Split in the Clan-na-Gael Originated," "Story of the Clan-na-Gael," Gaelic-American. Nov. 17, 1923, Jan. 17, 1925; Devoy's Post Bag, Vol. II, pp. 233-34. See also W. J. Burns to Devoy, oct. 8, 1884, Devoy's Post Bag, Vol. II, p. 256. For Western opposition to Sullivan see William 0'Mulcany to Devoy, 
New York nationalists also picked up valuable allies in Chicago, where for the past few years a small but spirited band of Irishmen had been battling Sullivan. In 1882, for instance, Patrick Dunne publicly denounced the Chicago lawyer for stealing Clan-na-Gael funds. Sullivan responded by asking Father Maurice Dorney, a close personal friend, to examine his accounts and determine the validity of the charges. Dorney's report exonorated Sullivan. Thus, backed by the testimony of a Catholic priest, Sullivan had Dunne tried and expelled from the Clan-na-Gael. 40

Besides Dunne, Sullivan had to contend with two other formidable opponents -- William J. Hynes and John Finerty. As we have mentioned previously, both of these men despised Sullivan as a corrupt machine politician; but they were also, no doubt, jealous of his rapid rise to the leadership of the Chicago Irish. The showdown between Sullivan and his antagonists occurred in early 1883, when Hynes and Finerty proposed the Clan should hold a rally to protest the recent Vatican circular denouncing the Parnell Tribute (a collection

Dec. 28, 1884, April 3, Dec. 18, 1885, Feb. 26, 1886, Devoy's Post Bag, Vol. II, pp. 258-59, 261, 268-69, 274-75. For Sullivan's resignation from the Executive Committee and the Clan see Cronin Committee, Open Letter to Patrick Ford, Chicago Inter Ocean, July 17, 1889; Majority Report on the Clanna-Gael Trial, 1888, Chicago Inter Ocean, May 27, 1889; 0'Mulcahy to Devoy, April 3, 1885, Devoy's Post Bag, Vol. II, p. 261; Beach, Twenty-Five Years, p. 235. ${ }^{40}$ Sullivan to Devoy, Oct. 19, 1882, Devoy's Post Bag, Vol. II, pp. 154-55; Chicago Inter Ocean, June 16. 1889, Devoy, "Story of the Clan-na-Gael," Gaelic-American, Dec. 27, 1924. 
intended to help Parnell pay his personal debts). Sullivan, however, opposed the meeting ostensibly on the grounds that it would be anti-Catholic and that such matters were of no concern to the Clan. Finerty and Hynes, nonetheless, went ahead with the demonstration. Sullivan, viewing the meeting as an attempt to undermine his influence, requested the IIIinois District Officer, Timothy Crean, to suspend Hynes' camp on the pretext that it was illegal for a club to hold a public meeting without the approval of Clan authorities. The camp, however, was quickly readmitted but without Hynes or his partisans. Sullivan did not have Finerty's camp expelled -- perhaps because the majority of its members were Sullivanites -- but instead began to wage war on the Citizen. 41 Finerty patched up his differences with Sullivan in the latter part of 1884. By then he probably realized it would be virtually impossible to have a successful Irish newspaper in Chicago if he continued to battle a man of SulIivan's power and influence. The presidential campaign of 1884, in which both Finerty and Sullivan supported Blaine, perhaps also served to bring the two men closer together. Thus, after 1884, Finerty generally sided with Sullivan. Devoy, however, always maintained that Finerty personally

${ }^{41}$ Diary of John Devoy, Devoy Papers, USS 9820, National Library of Ireland; Devoy, "Long Drawn Out Comedy at Philadelphia Convention," "Clan-na-Gael Convention in Boston Split the Organization," "Story of the Clan-na-Gael," Gaelic-American, Nov, 3, 10, 1923, Dec. 27, 1924; Chicago Citizen, Dec. 22; 1883, Jan. 5, Mar. 29, Aug. 23, 1884. 
hated the crafty lawyer and only supported him for political reasons and the sake of the citizen. 42

Although the opposition of Dunne, Hynes, and Finerty had created difficulties for Sullivan prior to 1884 , it was slight in comparison to the attacks Doctor Cronin launched on the Triangle from early 1885 to his murder in 1889. During his first few years in Chicago, Cronin, ironically, was on fairly cordial terms with Sullivan. Sullivan befriended the young doctor -- he had been a member of the Clan in St. Iouis -- upon his arrival in Chicago in November, 1882 and secured a position for him at the Cook County Hospital. Having a warm, outgoing personality and a fine tenor voice, Cronin rapidly became one of the most popular Irishmen in Chicago. He constantly delivered addresses and sang songs at Irish rallies. He also joined several patriotic, fraternal, and religious societies; in 1884 he was elected Senior Guardian of Camp 96 (Iater Camp 20) and President of the Eighteenth Ward Branch of the Irish National League. It is interesting to note that Cronin never attended demonstrations sponsored by Sullivan's enemies. 43

42 Diary of John Devoy, Devoy Papers, MSS 9820, National Library of Ireland; Devoy, "Clan-na-Gael Convention in Boston Split the Organization," "Story of the Clan-naGael." Gaelic-American, Nov, 10, 1923, Dec. 27, 1924. Chicago Citizen became pro-Sullivan in late 1884. See Chicago Citizen, Dec. 27, 1884, Jan. 31, 1885.

43 Hunt, The Crime of the Century, pp. 22-26; Beach, Twenty-Five Years, pp. 220-32; Diary of John Devoy, Devoy Papers, MSS9819, National Library of Ireland; Cronin Committee, Open Letter to Patrick Ford, Chicago Inter Ocean, July 17, 1889; Chicago Citizen, Oct. 20; Nov. 3, Dec. I, 
Cronin remained on friendly terms with Sullivan up until the end of 1884.44 But in early 1885 at a meeting of Camp 96 Cronin read the anti-Triangle circular from New York and began denouncing Sullivan. 45 It is difficult to know if Cronin had any motives for attacking Sullivan other than an honest belief that he was a menace to the Irish cause. Le Caron contended that personal ambition and jealousy played a large part in Cronin's decision to break with Sullivan. This theory may have an element of truth in it, but Le Caron's account of the Cronin-Sullivan split is often inaccurate. 46

1883, Jan. 12, 19, Feb. 2, April 26, May 31, 1884. 44 That Cronin remained friendly to Sullivan until the end of 1884 is indicated by the fact he attended the Sullivanite picnic at Ogden's Grove on August 15, 1884 and voted against permitting Sullivan's enemy, Finerty, to speak. Cronin did not attend the rival picnic at Oswald's Grove. In September Cronin was a house guest of Patrick Egan, Sullivan's ally, in Nebraska and in December Sullivan's brother, Florence, spoke at a meeting of the Eighteenth Ward Branch of the Irish National Ieague of which he was president. Chicago Citizen, Aug. 23, Sept. 6, Dec. 27, 1884; Cronin Committee, Open Letter to Patrick Ford, Chicago Inter Ocean, July 17, 1889; "Tullamore," Letter to the Editor, Irish-American, July 3, 1886. Cronin was probably somewhat suspicious of Sullivan throughout 1884. The Cronin Committee later claimed that Cronin had been making certain investigations and eventually discovered information that incriminated Sullivan. Cronin Committee, Open Letter to Patrick Ford, Chicago Inter Ocean, JuIy $17,1889$.

${ }^{45}$ Cronin Committee, Open Letter to Patrick Ford, Chicago Inter Ocean, JuIy 17, 1889; Chicago Inter Ocean, Aug. 12, 1089; Testimony of Thomas F. O'Connor, Daniel Brown, John O'Malley, Lawrence Buckley, and J. D. Haggerty at the Coroner's Inquest on the Cronin Murder, Chicago Inter Ocean, June $7,8,12,1889$.

46 of Cronin Le Caron said: "Very ambitious, like his future enemy Alexander Sullivan, he was never happy in a 
In any event, upon learning that Cronin had read the hostile circular to his camp, Sullivan's partisans appointed a committee to try him on charges of treason. Cronin was found guilty and expelled from the Clan-na-Gael. During the next four years Cronin, along with Devoy (he moved to Chicago in 1886), Hynes, Dunne and others waged a vigorous campaign against Sullivan and his gang. The Sullivanites in turn denounced their enemies as traitors to the Irish cause; in 1886 rumors floated around that the Triangle had

back seat, always thrusting himself forward and fighting for the place of leader. In fact, so pronounced were his ideas in favour of his supremacy, that where he could not rule he was quite prepared to ruin."

An examination of several sources (see the above two footnotes) contradicts much of Le Caron's account of the Sullivan-Cronin rift. Le Caron claimed that Cronin arrived in Chicago in the latter part of 1881, whereas he actually came in the autumn of 1882. Likewise, Le Caron dates "the commencement of undisguised hostility between Sullivan and Cronin" from the Chicago Clan-na-Gael Convention of August, 1881, in which, he contended, Devoy and Cronin opposed Sullivan's election as Chairman of the Executive Committee. Le Caron also asserted that Cronin was bitter that Sullivan had packed a meeting of the Eighteenth Ward Land Ieague in 1883 and selected his adherents to attend the Philadelphia Convention of the Irish National Ieague, and that he was equally disgusted when Sullivan's manipulations at the Illinois District Convention of the Clan-na-Gael resulted in the election of Sullivan and Lomasney as delegates to the Boston Clan Convention in 1884. While Cronin may have been unhappy over these events it appears unlikely there was "undisguised hostility" between the two men. If there was, it is illogical that Sullivan should have helped Cronin get established in Chicago and that Cronin was so popular among the pro-Sullivan Irish prior to 1885. Certainly, Sullivan had the power to undermine Cronin's influence, as was evident when the doctor was expelled from the Clan in 1885. If Cronin had been so hostile to Sullivan, he would not have associated with his followers; instead he would have aligned himself with his enemies, as he indeed did do after 1884. For Le Caron's account see Beach, Twenty-Five Years, pp. 220-26. 
sentenced Cronin and Hynes to death. 47

A few months after the Cronin trial the suspended clubs held a conference in New York to plan their strategy against the Triangle. They decided not to establish a rival organization but instead set up a Provisional Executive Committee to supervise the anti-Triangle clubs and keep in touch with the I. R. B. Furthermore, they made no effort to convince non-suspended clubs to withdraw from the Clan; rather they simply wanted to inform them about the Triangle, in the hope they would repudiate it and elect a new Executive. With this in mind the Provisional Executive Committee sent out a blistering circular to all Clan camps describing the Triangle's shady activities during the past few years. It accused them of fraud and of trying to further their own personal ambitions "at the expense of the sacred cause of Ireland," and denounced them for suspending clubs and ignoring the I. R. B. The Committee urged all camps to support a convention that would conduct an impartial investigation into the Triangle's operations. 48

47 Cronin Committee, Open Letter to Patrick Ford, Chicago Inter Ocean, July 17, 1889; Chicago Inter Ocean, Aug. 12, 1889; "Senior Guardian," Letter to the Iditor. Irish-American, Feb. 20, 1886; Testimony of Thomas F. O'Connor, Daniel Brown, John F. O'Malley, Lawrence Buckley, and J. D. Haggerty at the Coroner's Inquest on the Cronin Wurder, Chicago Inter Ocean, June 7, 8, 11, 1889.

${ }^{48}$ Circular from the Provisional Executive Committee of the Clan-na-Gael. Sept. 15, 1885, Hunt, Crime of the Century, pp. 70-77; Devoy, "How the First split in the Clanna-Gael Originated," "Story of the Clan-na-Gael," GaelicAmerican, Nov. 17, 1923, Jan. 17, 1925. 
During the next year the Devoyites picked up additional support from Clansmen throughout the country; some camps openly endorsed the New York Convention and were suspended from the Clan. 49 But the anti-Triangle forces achieved their most significant victory in August, 1886 at the Clan convention in Pittsburgh. The Triangle adroitly managed this gathering as it had the one at Boston. Once again there were charges the Sullivanites had packed the convention by admitting illegal proxies and by excluding unfriendIy bona-fide delegates. But as a concession to dissident groups the Sullivanites backed the election of the independent-minded James Reynolds as Convention Chairman. They also supported a new constitution that increased the Executive Committee from a body of three to seven; this, however, did nothing to diminish their control of the Clan. 50

There were present at the convention a few delegates -- Luke Dillon and Michael J. Ryan of Philadelphia and John King and Brennan of New Jersey -- who were upset with the Triangle but had stayed in the Clan, hoping to reform it from within. Besides the previous financial discrepancies, these individuals learned that the Triangle had claimed to have spent $\$ 87,000$ for "active work" during 1885 and 1886

\section{Devoy, "How the First Split in the Clan-na-Gael} Originated," Gaelic-American, Nov. 17, 1923; Irish-American, May 8, 1886.

${ }^{50}$ Constitution of the I. N. B. [Clan-na-Gael], 1886 , Special Commission, Vol. V, pp. Ill-19; Devoy, "How the First Split in the Clan-na-Gael Originated, "Gaelic-American, Nov. $17,1923$. 
that it had never done. Consequently, they asked the convention to appoint an impartial committee to investigate the Triangle's activities. When the convention refused to grant this request, the four delegates withdrew. A few other delegates sympathized with their position but continued to remain in the Clan. 51

The overwhelming majority of Philadelphia and New Jersey camps supported the action of the delegates at Pittsburgh. In early 1887, these clubs, the previously suspended camps, and a few non-suspended camps from New York held a convention in Brooklyn and established a rival Clan-na-Gael. Except for minor changes they adopted the pre-1884 constitution. Iuke Dillon was elected Chairman of an Executive Committee that also included Doctor Cronin. The I. R. B. officially recognized this group as its American affiliate. Thus, there were now two Clan-na-Gael organizations. 52 The internecine dispute that had been wrecking the Clan-na-Gael since late 1884 also had baneful repercussions on the Irish National Ieague of America. It should be noted, however, that the League had experienced considerable

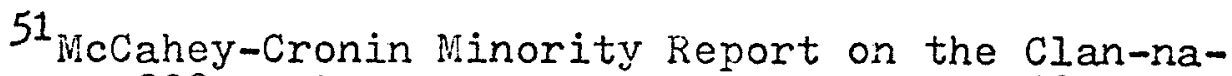
Gael Trial, 1888, Chicaso Inter Ocean, May 27, 1889. The majority report claimed that the Executive Committee's expenditures for the period were unbusinesslike and careless. Majority Report on the Clan-na-Gael Trial, 1888, Chicago Inter Ocean, May 27, 1889; Devoy, "How the First Split in the Clan-na-Gael Originated," Gaelic-American, Nov. 17. 1923. See also William J. Roche to James Reynolds, Aug. 17, 1886, Devoy's Post Bag, Vol. II, pp. 289-90.

52 Devoy, "How the First split in the Clan-na-Gael Originated," Gaelic-American, Nov. 17, 1923. 
strife even before the flare-up in the Clan-na-Gael: Since its foundation in April, 1883 one of the League's cardinal principles had been that it would not become involved in the entangling web of American politics. 53 Therefore, when Sullivan resigned as League President in August, 1884 and announced he was going to actively campaign for Blaine, many Irish Democrats, including Patrick Collins of Boston, justifiably felt he had used his position in the organization for partisan political purposes. They were even more infuriated when Patrick Egan, Sullivan's successor as President, publicly declared his support of Blaine. The Democratic editors of the Irish-American and the Boston Republic bitterly denounced Sullivan and Egan. The League's Vice-President, John Byrne of Cincinnati, resigned, claiming Sullivan and Egan had used the League as a political machine. 54

Irish Democratic politicians, therefore, had been at odds with the Sullivanites when the Clan-na-Gael split occurred in the winter of 1884-85. Throughout the rest of the decade these Democrats teamed up with the clerical element and the Devoyites in battling the Triangle for control of the constitutional Irish-American movement. The struggle often placed the Devoyites in an ironic position, for they

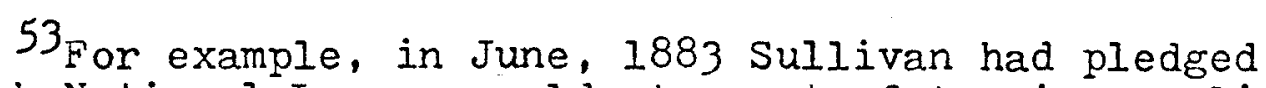
the Irish National League would stay out of American politics. Irish-American, June 30, 1883.

${ }^{54}$ Irish-American, June 7, Sept. 20, 27, Nov. 1, 15, 22, 1884; John Byrne, Letter to the Editor, Irish-American, oct. 11, 1884; Chicago Citizen, Dec. 27, 1884; Brown, IrishAmerican Nationalism, pp. 157-58. 
had to align themselves with politicians every bit as corrupt as Sullivan and Boland and with priests adamantly hostile to their revolutionary principles.

Since the Irish National League did not hold another convention until August, 1886, the immediate battle between the Sullivanites and their opponents was fought mainly on the local level, in the municipal councils. These bodies had become more significant after August, 1884 when the Boston Convention passed an amendment directing the local branches to send their contributions to Ireland through the municipal councils. 55 In cities like Chicago, where sullivan had the support of Republican and Democratic Clansmen alike, the Triangle so dominated the municipal council that the Devoyites found it impossible to make any serious inroads on its control. 56 In New York, however, the situation was different. In early 1885, when the lines between the Sullivanites and their enemies were clearly drawn, the municipal council was in the hands of the Devoyite-Tammany Hall coalition. But six months later in July the Triangle, through careful planning and manipulation, seized control of the city-wide organization and elected as President Michael Gallagher, a former Democrat who had supported Blaine. The Irish-American declared that honest men would now have to leave the organization they had worked so hard

\section{Brown, Irish-American Nationalism, p. 158. 56 For a list of the officers and branches of the} Irish National League in Chicago see Chicago Citizen, Jan. 12,1884 . 
to build. But the "honest men" did not abandon the League; they continued to fight the Sullivanites and in July, 1886 succeeded in re-capturing the municipal council. 57

Though the majority of Sullivan's critics continued to remain in the League, hoping eventually to capture the national structure, others deserted the organization in favor of rival groups. The first and most prominent of these was the Irish Parliamentary Aid Association. Founded in Cincinnati on January 24, 1885 by John Byrne, the exVice-President of the National League, its sole aim was to collect money to help pay the expenses of sending Irish M. P.'s to Westminster. Generally speaking, the Parliamentary Aid Association tried to appeal to wealthy Irish-Americans; Byrne was an affluent businessman, while the organization's treasurer, Eugene Kelly, was a multimillionaire banker from New York. Understandably, the Sullivanites did not appreciate the efforts of Byrne's group. Egan claimed it was a devisive force in Irish-America, established for the purpose of "gratifying personal jealousy." Nonetheless, despite this opposition, the Parliamentary Aid Association continued to grow. However, like the National League, it only began to receive considerable sums of money in the summer of 1885, when Parnell, after more than three years of relative quietude, launched a vigorous campaign for Home Rule. 58

57 Irish-American, July 18, Aug. 22, 1885, Jan. 17 April 3, 10, May 8, July 17, 1886 . 58 Irish-American, Feb. 7, 1885, April 3, 1886; 
On June 9, 1885 the Conservatives and Irish combined to defeat a liberal amendment on the budget and forced the Gladstone ministry to resign. Lord Salisbury formed a minority Conservative government pending the outcome of an election later in the year. Parnell supported the Tories and they reciprocated by ending coercion in Ireland and passing the Ashbourne Act, designed to help tenants purchase their farms from the landlords. Impressed by an EngIish party's eagerness to grant concessions in return for Irish votes, Parnell realized, if he played his cards right, he might be able to hold the balance of power in the next Parliament and offer his support to either the Conservatives or Iiberals in exchange for a Home Rule bill. In August he served notice on English politicians that the Irish were deadly earnest about Home Rule, declaring that in the new Parliament they would have "a platform with only one plank, and that one plank National Independence."

After considering what both parties had to offer, Parnell, on November 21, 1885, two days prior to the general election, came out in support of the Conservatives, asking the Irish in Britain to vote against Liberal candidates. The election was a magnificent victory for Parnell; as a result of a well-oiled political machine and the recent extension of household suffrage to Ireland, the Irish party captured eighty-six seats. The Liberals defeated the Conservatives in Britain, but the Irish and Tories together had 
two more seats in the new Parliament than the Liberals. Neither British party could govern without Parnell's assent, though it was extremely improbably the Conservatives, even with Irish support, could form a stable government with a fragile two-vote majority.

Gladstone, now secretly committed to Home Rule, at first refrained from making any overtures to Parnell. He hoped the Conservatives would come up with a Home Rule bill which the Liberals would then support; the Irish question would thus be kept out of British party politics. Whatever the chances of this plan, they vanished in mid-December when Gladstone's son, Herbert, disclosed that his father favored some form of Home Rule. Since the Conservatives could not match this -- it was unlikely in any event they would have introduced a Home Rule bill -- they gave up the idea of conciliating Parnell and started on an anti-Irish course. Parnell then threw his support to Gladstone and kicked the Tories out of office. In April, 1886 Gladstone introduced a limited Home Rule bill; the Irish would have their own parliament in Dublin and would no longer sit at Westminster, but the British would still control foreign affairs, trade, customs, the post office, and the currency. Many liberals led by Chamberlain and Dilke deserted Gladstone and joined the Conservatives in defeating the bill 343 to 313. In July another election was held; the Conservative-Liberal Unionist coalition scored another victory, thus assuring that Home Rule would be a dead issue for the 
next few years. 59

All Irish-American nationalists, save the most intransigent extremists, welcomed the Home Rule struggle. The Clan-na-Gael, convinced that the dynamite campaign had been partially responsible for Gladstone's conversion to Home Rule, suspended its terrorist activities in December, 1885. so as not to imperil the passage of a Home Rule bill in the new Parliament. 60 And although most Clansmen had expected a greater degree of Irish self-government than the Gladstone bill actually provided, they supported it as a step in the right direction. Sullivan, for example, declared:
While the race knows that Ireland is entitled to more, and while it prays and works for complete justice to Ireland, he would indeed be a foolish friend . . who would seek to embarrass the Irish Parliamentary Party or to interfere with its judgement in the acceptance of the best that can be accomplished under the present circum- stances.61

The Home Rule movement also did much to improve the

59 For the Home Rule struggle see Conor Cruise O'Brien, Parnell and His Party, 1880-90 (London: Oxford University Press, 1958), pp. 80-194; Nicholas Mansergh, The Irish Question, 1840-1921 (London: Unwin University Books, 1965), pp. $123-52$.

${ }^{60} \mathrm{Circular}$ from the Clan-na-Gael Executive Committee, Dec. 23, 1885, Beach, Twenty-Five Years, pp. 246-47.

${ }^{61}$ Cited in unidentified Washington, D. C. newspaper, Scrapbook of American Public Opinion Editorials from the Leading Papers of America on the Home Rule Bill for Ireland - - Presented to the Rt. Hon. William E. Gladstone from the Irish National League of America, Harrington Papers, MSS 9210, National Library of Ireland. For other extremist opinion see above and Irish World, Dec. 26, 1885. 
slumping financial condition of Irish-American organizations. Upon receiving the news in June, 1885 that Gladstone's government had resigned and that there would be a crucial election later in the year, clansmen and conservatives in the National League laid aside their differences and united in launching a vigorous campaign to collect funds for Parnell. From all over the nation, from Triangle and anti-Triangle strongholds alike, contributions poured into the League's Parliamentary Fund. So overwhelming was the response that at the Chicago Convention in August, 1886, the League's treasurer could report that $\$ 314,000$ had been donated to the Parliamentary Fund since the last convention. 62 Similarly, in Chicago the Sullivanites and most of their enemies temporarily joined forces in October, 1885 and raised a special fund of $\$ 10,000$ to aid Parnell in the upcoming election. 63 This show of unity failed to develop into anything more lasting, but it was a testimony to the popularity of Parnell and Home Rule that even this was accomplished.

The National League's rival, the Irish Parliamentary Aid Association, which had grown slowly enough during the early months of 1885, began to mushroom in several cities as Home Rule loomed on the horizon. Perhaps, the Associa-

62 Third General Convention of the Irish National League of America, reprinted in Special Commission, Vol. XI, appendix, p. 736. See also Irish-American, July 4, Aug. 29. Sept. 19, Oct. 24, 31, Nov. 28, 1885.

${ }^{63}$ Chicago Citizen, Sept. 26, oct. 10, 31, 1885; Irish World, Oct. 24, 31, 1885. 
tion's most notable achievement occurred in New York where its Hoffman House Committee collected $\$ 150,000$ between November, 1885 and August, 1886. To a large extent this group was composed of affluent Irish-Americans, who for the first time were showing a real interest in the Irish struggle. Unlike their counterparts in Chicago, wealthy New York Irishmen had been reluctant to involve themselves in radical movements like the Fenians and the Land League, no doubt feeling that they would hurt their image as responsible Americans. But the Home Rule movement, strictly constitutional and unencumbered by any radical social theories, was a cause these respectable Irishmen could easily support. 64

Most Americans of non-Irish heritage also sympathized with the Home Rule movement, a movement that simply demanded for Ireland the local autonomy American states already enjoyed. Throughout the country, government officials and civic leaders joined Irish-Americans in mass demonstrations to voice their support for Parnell, Gladstone, and Home Rule. In May, 1886 Illinois Governor Oglesby and Mayor Harrison spoke at a huge Home Rule rally in Chicago. Later that summer both the Republican and Democratic state conventions in Illinois endorsed Home Rule; two years later the two national political conventions followed suit. 65

${ }^{64}$ Irish-American, Dec. 5, 12, 1885, Jan, 23, Nar. 13, 1886; Brown. Irish-American Nationalism, pp. 168-71.

${ }^{65}$ Chicago Citizen. May 29, 1886; Chicago Daily News Almanac, $1886, p p .53-54 ;$ officia]. Proceedings of the RepubIican National Convention, 1888 (ilinneapolis: Charles $W$. 
In any event, American public opinion carried little weight when British voters went to the polls in July, 1886 and elected the anti-Home Rule coalition of Conservatives and Liberal Unionists. Parnell and his American allies were bitterly disappointed at the failure of Home Rule, a prize that had seemed well within their grasp earlier in the year. But they could at least take some consolation in the fact that Gladstone, considered the personification of English tyranny only a few years before, had been converted to their cherished cause. Gladstone and the Irish Party were now joined in a firm alliance, and it was upon that alliance Parnell eventually hoped to achieve Home Rule. Most Irishmen and conservative Irish-Americans agreed with their leader that the only chance for Irish self-government lay in the Liberal-Irish pact. Triangle Clansmen, however, viewed the matter differently. For them the defeat of Home Rule was one more proof that constitutional agitation was foolhearty and ineffective. It was time to stop the talking, they reasoned, for the English only Iistened to dynamite and gunpowder.

Johnson, 1903), p. 109; Official Proceedings of the National Democratic Convention, 1888 (St. Louis: Woodward and Tiernan Printing Co., 1888), pp. 101-02. See also Scrapbook of American Public Opinion Editorials from the Leading Papers of America on the Home Rule Bill for Ireland... Presented to the Rt. Hon. William E. Gladstone from the Irish National League of America, Harrington Papers, MSS 9210, National Library of Ireland; Scrapbook of American Public Opinion Editorials from the Leading Papers of America on the Home Rule Bill for Ireland . . . Presented to Charles S. Parnell from the Irish National League of America, Harrington Papers, MSS 9211, National Library of Ireland. 
Actually, the Clan had been flexing its muscles even prior to the defeat of Home Rule. In March, 1886 it indicated its intention to renew the dynamite campaign after the Home Rule bill was approved. Though supporting the measure as a step in the right direction, Clansmen felt that a few more explosions here and there would force the Iiberals into even greater concessions. 66 In fact, in the spring of 1886 there were rumors that the $\mathrm{Clan}$ had sent over an envoy to warn Parnell that, if he did not continue to work for complete independence, they would withhold National League funds. 67 The envoy may have been Sullivan's wife, Margaret. She visited England in May; William O'Brien, an Irish M. P. and editor of United Ireland, tells us that when Parnell saw her sitting in the gallery of the House of Commons he was afraid she would throw down a bomb and destroy the chances for Home Rule! 68

If Parnell was apprehensive about the Clan-na-Gael in May, he was even more so after the Home Rule bill was rejected in June. He feared that if the Clan renewed the dynamite campaign it would jeopordize his alliance with Gladstone and spell disaster for Home Rule. As events turned out, he had little to worry about on this score. Though the

${ }^{66}$ Circular from the Clan-na-Gael Executive Committee, early, 1886, Beach, Twenty-Five Years, pp. 248-49.

67 Irish World, April 10, 1886; Chicago Citizen, April 10, 1886 .

68 William 0'Brien, Evening Wemories (Dublin: Maunsel and Co., 1920), pp. 124-25. 
Clan did indeed vote for dynamite at the Pittsburgh Convention in August, 1886, it participated in only one expedition, the abortive plot to celebrate Queen Victoria's Jubilee (1887) with a few well-time explosions. Perhaps the Clan refrained from a full-scale dynamite program out of deference to Parnell, but a more plausible reason is that internal dissension and opposition to terrorism made such a campaign unfeasible. 69

Parnell was also concerned that at the Irish National League Convention scheduled to meet in Chicago that August, the Sullivanites, embittered over the failure of Home Rule, would publicly support violence as the only practical way to achieve Irish independence. Should this occur, it would give Parnell's English critics all the more ammunition for their charges that he was in league with revolutionaries. The Irish leader, fearing Sullivan and the Clan would deliberately try to embarrass him, decided not to attend the Chicago Convention as the League's officers had hoped; instead he sent as his representatives three other Irish M. P.'s -- William O'Brien, John Redmond, and John Deasy. 70

The Irish envoys left for the United States in early August. While they were at sea, Clansmen in Chicago gathered in Ogden's Grove for the annual August 15 picnic of the United Irish Societies, a Clan-na-Gael front. Had the

${ }^{69}$ Beach, Twenty-Five Years, pp. 255-56, 281-89; Ryan, Fenian Memories, p. 135; Devoy's Post Bag, Vol. II, p. 298. 700 Brien, Evening Wemories, pp. 136-38. 
Irish delegates been able to hear what was going on, their worst fears about the Chicago Convention would have been confirmed. With Finerty acting as Chairman and such notables as Sullivna, Egan, and Davitt on the platform, Natthew P. Brady read the official address of the United Irish Societies. Among other things it affirmed Ireland's right to revolution, declaring the country could never hope to achieve self-government through constitutional means alone; and while it cautiously commended Parnell for his parliamentary efforts, it also criticized him, asserting that any Irish leader accepting the "infinitesimal measure of justice or redress as was lately proposed by Mr. Gladstone's bill as the final settlement of the Irish question was violating the trust of the Irish people." But these resolutions were tame compared to Finerty's speech; Long John defended the right of Irish-Americans to carry on dynamite attacks against Britain even if the Irish opposed the idea. Davitt, a convert to the creed of non-violence, attacked Finerty, claiming:

The fight for Irish national selfgovernment looks, perhaps, different in Ireland to what it does in Chicago. It is very easy to establish an Irish republic, three thousand miles away from Ireland by patriotic speeches. I assure you it is no easy task, though, to do it in old Ireland.71

The Irish delegates arrived in Chicago three days after the Clan picnic, and according to $0^{\prime}$ Brien, Sullivan

${ }^{71}$ Chicago Citizen, Aug. 21, 1886; Diary of John Devoy, Devoy Papers, National Iibrary of Ireland, MSS 9820; Devoy, "Pseudo Revolutionists Tapped Davitt at the 1886 Convention," Gaelic-American, sept. 22, 1923. 
fully intended to have the Irish National League endorse resolutions similar to those at Ogden's Grove. However, at a meeting held on the evening prior to the convention the Irish delegates (Davitt, Ford, and Egan were also present) persuaded Sullivan to change his mind and support moderate resolutions. They found it a somewhat more difficult task to convince him not to nominate Reverend George Betts, an Episcopalian clergyman from St. Iouis, as Egan's successor to the presidency. The Irish envoys opposed Bett's nomination on the grounds that he was a well known advocate of dynamite and would, therefore, compromise Parnell's position as a constitutional leader. Finally, after considerable argument, Sullivan relented and instead decided to support John Fitzgerald, a supposedly illiterate millionaire from Nebraska. Fitzgerald was as much a Sullivan-Egan lackey as Betts, but at least he did not have the St. Louis minister's reputation as a firebrand. ${ }^{72}$ Devoy always claimed Sullivan had never intended to embarrass Parnell at the convention, but had deliberately created the impression Clansmen were out for blood so it would appear he was the only man with the power to stop them. Devoy contended that Sullivan and Egan personally hated Parnell because he had not approved some of Egan's financial transactions as Land League Treasurer, including, presumably, the $\$ 100,000$ he had given to Sullivan in 1882.73

\footnotetext{
$720 \cdot$ Brien, Evening Memories, pp. $141-48$. ${ }^{73}$ Diary of John Devoy, Devoy Papers, National Lib-
} 
With Sullivan's pledge to support the Parnellite program, the Irish envoys had an easy time at the convention. After minor opposition from intransigents like Finerty, the assembly approved a series of conservative resolutions, congratulating Parnell and Gladstone for their efforts on behalf on Home Rule, and expressing gratitude to "the English, Scotch, and Welsh democracy" for their support in the last election. Similarly, the speeches of Sullivan, Egan, and others were on the whole rather restrained. However, Finerty, partially under the beneficent effects of alcohol, gave a spirited address urging the Irish to take up arms as soon as England became entangled in a European war. After Finerty had carried on for some time, Davitt stood up, and in a scene reminiscent of Ogden's Grove, denounced him, asserting he might be less belligerent if he was living in Ireland. Finerty became enraged and was about to physically assault the one-armed Davitt when the convention chairman stopped him. But except for Finerty's outburst the convention had been smooth sailing for the Parnellites. 74

rary of Ireland, MSS 9820; Devoy, "Pseudo Revolutionists Tapped Davitt at the 1886 Convention," Gaelic-American, Sept. 22, 1923.

$$
\text { 74"Third General Convention of the Irish National }
$$
League," reprinted in Special Commission, Vol. XI, appendix, pp. 719-57; Chicaro Citizen, Aug. 21, 28, Sept. 25, 1886; Diary of John Devoy, Devoy Papers, MSS 9820, National Library of Ireland; Devoy, "Pseudo Revolutionists Tapped Davitt at the 1886 Convention," Gaelic-American, Sept. 22, 1923; 0'Brien, Evening Nemories, pp. 148-54; Michael Davitt, The 'Times'-Parnell Comm Saicr: Speech Delivered by Michael Davitt in Defence of the Land League (Iondon: Kegan Paul, Trench, Truoner, and Co., 1890), p. 126, 165-67. 
Perhaps one of the reasons Sullivan had not opposed Parnell was the realization that he had his hands full with his American enemies, the Devoyites and the conservatives. For months prior to the convention the anti-Triangle faction had been spreading reports that Sullivan was a dishonest politician and that he and Egan were trying to undermine Parnell's campaign for Home Rule. 75 Viewing the convention as an opportunity to unseat the Triangle, the Devoyites made a concerted effort to send their supporters to Chicago. As a result they controlled the majority of delegates from Massachusetts, New York, New Jersey, Pennsylvania and Iowa; two of Sullivan's chief Chicago opponents, Devoy and Cronin, were elected as proxies from branches in New York. ${ }^{76}$ Nonetheless, the Sullivanites still managed to dominate the convention. They also had launched a drive urging their partisans to attend. In cases where branches could not send representatives, they were instructed to grant Egan the permission to appoint proxies. Consequently, several of Sullivan's Chicago loyalists attended the convention as proxies

75 Irish-American, Dec. 5, 1885, Jan. 23, 30, April 24, Aug. 14, 1886; "Viator," Letters to the Editor, IrishAmerican, Dec. 24, 1885, Jan. 10, 1886; "Delegate," Letter to the Editor, Irish-American, Mar. 27, 1886; "Senior Guardian," Letter to the Editor, Irish-American, Feb. 20, 1886; "Tullamore," Letter to the Editor, Irish-American, July 31 , 1886; Irish World, Sept. 4, 1886.

76 Irish-American, Aug. 28, 1886; "Third General Convention of the Irish National League of America," Special Commission, Vol. XI, appendix, pp. 728, 739; Devoy, "Pseudo Revolutionists Tapped Davitt at the 1886 Convention, "GaeIic-American, Sept. 22, 1923. 
from other states; Devoy claimed that about 250 of these were illegally appointed. 77 The sullivanites were clearly over represented at the convention. For instance, though the four anti-Triangle states of Massachusetts, New York, New Jersey, and Pennsylvania had contributed 60 percent of the total $\$ 314,000$ in the Parliamentary Fund, they had only 36 percent of the delegates. On the other hand, the four Triangle states of Illinois, Michigan, Nebraska, and Wisconsin had donated 9 percent of the fund but accounted for 21 percent of the delegates. 78 The fact that the convention met in Chicago was, therefore, an immense benefit to the Triangle. The Devoyites, believing Sullivan would actively oppose Parnell's policy, had expected a major confrontation over the resolutions. But since Sullivan supported the Parnellite program, there was no dispute on this issue. The chief battle occurred over the presidency. The anti-Triangle faction was relieved Egan was not seeking re-election, and many conservatives, for the sake of harmony, were willing to support Fitzgerald; even though he was a close friend of Egan, they considered him an honest man. But a substantial number of Devoyites opposed the wealthy Nebraskan and nominated instead Hugh McCaffrey, a Philadelphia merchant and

${ }^{77}$ Circulars from the Clan-na-Gael Executive Committee, July 20, 24, 1886, Irish-American, Aug. 14, 1886; Beach, Iwenty-Five Years, pp. 235-36; Devoy, "Pseudo Revolutionists Tapped Davitt at the 1886 Convention," GaelicAmerican, Sept. 22, 1923.

78 Based on figures in "Third General Convention of the Irish National League of America," Special Commission, Vol. XI, appendix, pp. 726-30, 736 . 
manufacturer. Though McCaffrey requested his name be withdrawn, intransigent Devoyites demanded a roll call. Fitzgerald, however, won handily by a margin of 739 to 242 . In a spirit of conciliation McCaffrey was chosen as VicePresident. But the Triangle captured the new Executive Council and continued to remain in firm control of the League. 79 The factionalism manifest at chicago continued to plague the League during the next few years until 1889, when the Cronin murder would destroy all semblance of unity. 80 During this period the League also had to cope with fundraising problems; between the Chicago Convention and the end of 1889 the League had managed to collect only $\$ 257,923$, a paltry sum compared to what had been raised during the Home Rule struggle. ${ }^{81}$ These figures, of course, merely reflected the apathy that had developed in Irish-America as a result of nationalist inactivity in Ireland following the defeat of Home Rule. The only sign of Irish militancy during these years was the Plan of Campaign. Founded in 1887 and led by two Irish M. P.'s, Timothy Harrington and William O'Brien, the Plan was designed to force landlords to reduce rents; tenants deposited their payments in escrow until such time

79 "Third General Convention of the Irish National League of America," Special Commission, Vol. XI, appendix, pp. 737-40, 757; Irish-American, Aug. 28, 1886.

${ }^{80}$ See Irish World, Sept. 4, 1886, June 25. July 2, 9. 1887; John Sutton, Letter to the Editor, Irish World, July 23, 1887; Irish-American. Dec. 15, 1888, June 15, 1889. ${ }^{81}$ Irish-American, Feb. 8, 1890 , Chicago Citizen, Jan. $22,1887$. 
as the landlord was willing to lower the rents. The Catholic Church condemned the movement as a violation of personal property rights, and neither Parnell nor the Irish Parliamentary Party officially sanctioned it. The American League, however, vigorously endorsed the Plan and protested the Vatican's meddling in Irish politics. ${ }^{82}$ Despite their public friendliness for Parnell and Gladstone, League officials were privately disgusted at the lethargic state of Irish affairs. In September, 1888 John Sutton, Secretary of the American League, writing from Iincoln, Nebraska to a local League official in Carrick-on-Suir, declared:

It looks to us in America as if there was damned little business capacity connected with your League Executive, whatever kind of a "he" -- "she"-- or "it" runs it. In fact only for the cause itself Irish Americans would long ago peruuit ( $s i c$ ) your distinguished leaders to hoe their own path.

If $\mathrm{Mr}$. Peare (a Tipperary landlord) and his like would try to inaugurate an Irish eviction campaign in Nebraska, shotguns would be thicker than blackthorns at an Irish fair, and the amusement would wind up with a lynching bee if $M r$. Peare's carcass was not perforated like a seive earlier in the day. God help the Irish people! between law and order harangues, and doses of moral theology, it is a wonder there is an ounce of unemasculated manhood left in the country. 83

82 Irish-American, Jan, 28, 1887; Chicaso Citizen, Jan. 15, 1887, May 19, June $16,1888$.

83 John P. Sutton to Thomas A. Lynch, Secretary, Carrick-on-Suir, Co. Tipperary Branch of the Irish National League, Sept. 17, 1888, Harrington Papers, National Library of Ireland. 
In what were rather trying years for Irish-American nationalists, it is surprising that one of the few glimmers of hope came from the faction-torn Clan-na-Gael. Despite their decision to establish a rival Clan in 1887 , the antiTrianglers still continued to work for unity. While on a tour to organize anti-Triangle clubs in the Middle West, Devoy met with several open-minded Sullivanites. After one such meeting in Indianapolis, a Triangle camp wrote to their Executive Committee asking it to take the necessary steps to heal the schism. Realizing this letter typified the sentiments of many rank and file members, and perhaps also fearing Devoy's group would eventually eat into their numbers, the Triangle called a conference to discuss the question of union. Composed chiefly of Triangle delegates, this conference in turn appointed a committee from both factions to draw up a plan for unification. After carefully considering the matter, the Devoyites rejected the idea of the joint committee; they felt it was stacked against them since their representatives on it were inexperienced, "peace at any price men." Nonetheless, negotiations between both sides continued, and they finally reached an agreement to hold a joint convention. Each camp was permitted to send one delegate. 84 In June, 1888 Clansmen from both factions gathered in Chicago in an attempt to restore unity. The majority of delegates were Trianglers, but a significant number of these

${ }^{84}$ Devoy, "How the First Split in the Clan-na-Gael Originated," "Story of the Clan-na-Gael," Gaelic-American, Dec. 20, 1924, Jan. 31, 1925. 
were moderates determined to patch up their differences with their opponents; Devoy claimed that between twenty-five and thirty Trianglers usually voted with his followers. The chief obstacle to union was the long standing anti-Triangle charges that Sullivan, Boland, and Feeley were guilty of fraud, had severed ties with the I. R. B., and neglected the dynamiters and their dependents. The convention appointed a judiciary committee to investigate these accusations. The committee delivered a compromise verdict; it neither found the triumverate guilty nor innocent but recommended that the convention censure them for financial extravagance (not fraud) and for neglecting the Clan's interests, particularly in regard to its connection with the $I . R . B$. The majority of Devoyites, however, considered this action inadequate and demanded a formal trial. The convention finally acceded to this request when the Devoyites threatened to withdraw if it was not granted. A six-man trial committee, composed of individuals from both sections, was established. Appointed on the Triangle side were Patrick A. O'Boyle of Pittson, Pennsylvania, Christopher F. Byrnes of Saxonville, Massachusetts, and James J. Rogers of Brooklyn. Representing the Devoyites were Doctor Cronin, Doctor Patrick McCahey of Philadelphia, and John D. Miriahon of Rome, New York. Several Sullivanites strongly objected to Cronin's appointment but were outnumbered by a coalition of Devoyites and moderate Trianglers, convinced that the personal feelings of Sullivan and his cronies should not stand in the way of union. 
With this problem out of the way, the delegates voted to unite the two rival factions. They elected a nine-man Executive Committee; five members were Trianglers, four antiTrianglers. John J. Bradley, a Philadelphia Sullivanite, was elected Chairman. 85

The trial comittee held its first few sessions in Buffalo on August 20, 21, 1888 but then decided to adjourn and move to New York, since several witnesses lived in that area. On september 6 the committee reconvened at the Westminster Hotel in Manhattan but had to leave there within a few days, when it was learned the press had gotten wind of the proceedings. They finally transferred the trial to a room above a Third Avenue saloon. The hearing was a stormy affair. Several participants, including Sullivan and Devoy, carried guns, and at least on one occasion a shooting spree almost broke out. 86

${ }^{85}$ Diary of John Devoy, Devoy Papers, MSS 9819, 9820, National Library of Ireland; Devoy, "Le Caron, the Spy, Sponsored by Davitt's Friend Sullivan," "Clan-na-Gael Convention in Boston Split the Organization," "How the First Split in the Clan-na-Gael Originated," "Story of the Clanna-Gael," Gaelic-American, Sept. 15, Nov. 10, 17, 1923, Dec. 20, 1924, Jan. 31, Feb. 7, 1925; Beach, Twenty-Five Years, pp. 258-62; Hunt, Crime of the Century, pp. 79-80. Besides Bradley the Triangle members on the Clan-na-Gael Executive Committee were Thomas H. Ronayne (New York), Patrick Egan (Lincoln, Nebraska), John $\mathrm{N}_{\text {. Leonard (Fall }}$ River), Lawrence Buckley (Chicago); the anti-Triangle members were Joseph Tierney (Brooklyn), Luke Dillon (Philadelphia), Edward $M$. O'Condon (New York), and Fortimer Scanlan (Chicago), Special Commission, VoI. V, p. 49.

${ }^{86}$ James P. Rogers, Report on the Clan-na-Gael Trial, 1888, Sept. 26, 1888, Irish World, June 15, 1889; Cronin, Notes on the Testimony at the Clan-na-Gael Trial, 1888, in Hunt, Crime of the Century, pp. 88-100; Hunt, Crime of the 
The first session in Buffalo was typical of many that followed. With McMahon sitting as Chairman, Sullivan asked the committee to replace Cronin, claiming justifiably that the doctor was his inveterate enemy and could not possibly serve as an impartial juror. This charge set off a heated argument between Sullivan and Cronin. Boland and Feeley then joined the Chicago lawyer in demanding Cronin's removal. Boland added more fuel to the fire when he requested that Devoy be excluded from the proceedings, since, he claimed, he had given secret information to the British in the past. However, the trial committee, in an obvious attempt to conciliate the dissidents, voted to retain both Cronin and Devoy. 87

With Michael Ryan acting as their legal counsel, Devoy and Dillon presented a series of charges against Sullivan, Boland, and Feeley. They accused them of financial irregularities, breaking off relations with the I. R. B., neglecting the dynamiters and their families, and illegally packing the Pittsburgh Convention., They made no mention, however, of the $\$ 100,000$ Sullivan had received from Egan in 1882, thus easing Parnell's fears that the trial (should the proceedings leak out) might implicate the Irish Land League

Century, p. 83; Chicago Tribune, Sept. 11, 1888; Devoy, "Story of the Clan-na-Gael," Gaelic-American, Jan. 10, 31 , 1925.

${ }^{87}$ Cronin, Notes on the Testimony at the Clan-naGael Trial, 1888, in Hunt, Crime of the Century, pp. 88-100; Devoy, "Story of the Clan-na-Gael," Gaelic-American, Jan. $31,1925$. 
and, hence, him with the revolutionary Clan-na-Gael. 88

Numerous witnesses testified at the trial. Several dynamiters stated they had received insufficient funds for their daring missions and had been left stranded in England. One conspirator claimed he had to sell his clothes to pay his passage back to the United States. Other witnesses testified the Triangle had refused to grant funds to the needy dependents of imprisoned dynamiters. Perhaps the most pathetic witness was the wife of William Mackey Lomasney, the victim of the London Bridge explosion of 1884. Describing her poverty-stricken condition in Detroit, she explained how she had gone to Chicago twice to ask Sullivan for money, but that he had refused to give her anything except a \$100 10an. 89

The trial committee heard the testimony of the final witness on September 16 and then adjourned for a brief period to permit some of the participants to campaign in the 1888 election. On reconvening, the committee, by a vote of four to two (Cronin and McCahey dissented), cleared the Triangle of the most serious charges. The majority agreed, however, that "large sums of money were expended which brought no fruit and might be thus termed injudicious outlay," but

\section{${ }^{88}$ Devoy, "Clan-na-Gael Convention in Boston Split} the Organization," "How the First Split in the Clan-naGael Originated," Story of the Clan-na-Gael," Gaelic-American, Nov. 10, 17, 1923, Jan. 3, 31, 1925, Feb. 7, 1925.

${ }^{89}$ Cronin, Notes on the Testimony at the Clan-na-Gael Trial, 1888, in Hunt, Crime of the Century, pp. 88-100; Devoy, "Story of the Clan-na-Gael," Gaelic-American, Feb. 7, 1925: McEnnis, The Clan-na-Gael, p. I49. 
claimed there was no evidence to show the Triangle had stolen any funds. They also admitted the Clan had been guilty of neglecting the Lomasney family, and at least one member censured Boland and Feeley for this. Sullivan was acquited of all charges; McMahon, the Committee Chairman, declared he was fully convinced of "the manhood, honor, integrity, and patriotism of Alexander Sullivan." 90

Cronin and McCahey, on the other hand, found SuIlivan, Boland, and Feeley guilty on several counts. They accused them of falsifying their accounts during the period 1881-84 and of spending $\$ 111,000$ "without any direct benefit to the order" and without consulting the I. R. B.; of excluding John $\mathrm{O}^{\prime}$ Connor, the I. R. B. envoy, from the Boston Convention; of illegally suspending camps in 1885 and 1886; and of failing to provide financial assistance to the Iomasney family. Furthermore, Cronin and McCahey charged Boland and Feeley (but not Sullivan) had unlawfully packed the Pittsburgh Convention and had reported spending over $\$ 80,000$ for "active work" that had never been done.91

Cronin, McCahey and Devoy considered the majority

$90 \mathrm{~J}$. D. Mcliahon and C. F. Byrnes, Report on the Clanna-Gael Trial, 1888, Jan. 16, 1889; James P. Rogers, Report on the Clan-na-Gael Trial, 1888, Sept. 26, 1888; P. A. O'Boyle, Report on the Clan-na-Gael Trial, 1888, Irish World, June 15, 1889. For somewhat different versions see Devoy, "Story of the Clan-na-Gael," Gaelic-American, Feb. 7. 1925: Beach, Twenty-Five Years, pp. 258-62; Hunt, Crime of the Century, pp. 83-84.

${ }^{91}$ Cronin-Miclahey Minority Report on the Clan-na-Gael Trial, 1888, in Hunt, Crime of the Century, pp. 87-88. 
report an outrageous travesty of justice. Devoy contended Rogers and $0^{\prime}$ Boyle had refused to convict the triumverate because they were Triangle lackeys; that Byrnes, though an honest and independent-minded man, had voted with the majority so as to prevent strife in the organization; and that McMahon had defected to the Triangle side because Feeley had helped him win re-election to a local office in upstate New York. 92

Whatever their reasons, the majority had refused to convict the Triangle of the more serious charges, and for the sake of harmony the Devoyites would have been better advised to have accepted this decision. Unfortunately, they refused to do this. Cronin returned to Chicago determined to crush Sullivan at all costs. Though the trial committee had voted to destroy all records, Cronin refused to hand over his personal notes and instead asked the Executive Committee to send copies of these and the minority report to the various Clan camps. When it refused to do this, he began reading his report to friendly camps in Chicago and threatened to do the same at the next convention of the Irish National League scheduled to meet in Philadelphia sometime in 1889. He also attacked Sullivan in his recently established newspaper, the Celto-American; and he wrote a pamphlet, claiming the Triangle was trying to slander his character and might eventually attempt to murder him. These

92 Devoy, "Story of the Clan-na-Gael," Gaelic-American, Feb. 7, 1925. 
actions naturally infuriated the Sullivanites and destroyed the slight degree of unity that had developed in Chicago since the joint convention in June, 1888. To make matters worse, in February, 1889 the British spy Le Caron, a resident of the same Near North Side neighborhood as Sullivan and Cronin, appeared on the witness stand at the Special Commission investigating Parnell's connections with revolutionary organizations. His disclosures on the Clan shocked and embarrassed the Irish in Chicago. But more importantly Ie Caron had claimed there were four other British spies presently living in the United States. Sullivan's adherents, conveniently overlooking the fact that Le Caron had sided with the Triangle in the Clan-na-Gael split, began charging that Cronin was one of these culprits. The doctor was understandably alarmed; Irishmen suspected as British spies did not have a long life expectancy. 93

93 Hunt, Crime of the Century, pp. 84-86; MicEnnis, The Clan-na-Gael, pp. 117-20, 156, 159-61, 231; Beach, Twenty-Eive Years, pp. 251, 262, 266-69; Devoy, "Story of the Clan-na-Gael," Gaelic-American, Jan. 31, 1925; Chicago Citizen. Dec. 1, 29, 1888; Irish World, sept. 8, 1888; Irish-American, Nar. $30,1889$. 
On Saturday evening, May 4, 1889, a stranger called at Doctor Cronin's office, asking him to attend to an injured worker at the O'Sullivan Ice Company in suburban Lake View. When Cronin failed to return home by the following morning and the proprietor of the ice company denied any knowledge of the whole affair, Cronin's friends, well aware of the rumored threats on his Iife, feared that some of Sullivan's henchmen had Iured him away on a bogus emergency call for the purpose of murdering him. They became even more apprehensive when a blood spattered trunk, which had seemingly contained a corpse, was found some hours later in Lake View. Heeding the pleas of Cronin's friends, Lake View and Chicago police made an apparently thorough search for his body but failed to find any trace of the missing man. ${ }^{1}$ The case, however, took an unexpected twist a few days later when a young man named Frank Woodruff told police that he had helped three men, one of whom resembled Cronin, to dispose of a female corpse. Though the police failed to

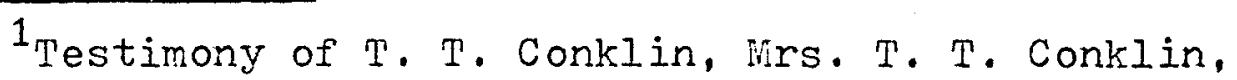
Sarah McNearney, Agnes McNearney, Frank T. Scanlan, Frank Murray, and Laura Hermann at the trial of The People v. o'sullivan and others (hereafter cited as the Cronin trial), reprinted in Chicago Inter Ocean, Oct. 29, 30, Nov. 8, 1889; Chicaso Herald, Hay 6-9, 1889; Henry M. Hunt, The Crime of the Century or the Assassination of Doctor Patrick Cronin (Chicago: H.L. and D.H.Kockersperger, 1889), pp. 27-45; "The Case of Dr. Cronin," Federal Writers Project unpublished MSS, Illinois State Historical Society, p. 128. 
find the body, many Chicagoans believed that Cronin had accidentally killed a woman while performing a criminal abortion and had fled the city to avoid prosecution. Other reports also tended to substantiate the theory that Cronin was alive. A young Irish-American girl and a street car conductor recalled they had seen Cronin on a Chicago streetcar sometime after the hour he was supposedly murdered. Furthermore, Charles T. Long, a former Chicago reporter, claimed he had spoken to Cronin in Toronto and had gotten the impression he was planning to travel to England to testify as a prosecution witness before the Special Commission investigating Parnell. 2

Taken as a whole, these accounts convinced most people that Cronin was still very much alive. Many felt he had left Chicago to avoid abortion charges or was travelling to England to testify against Parnell. Others speculated that he was involved in an eccentric love affair or that he had staged the whole escapade for publicity purposes. Even the Irish-American, a consistent supporter of Devoy and Cronin, ridiculed the idea that the missing physician had been murdered by his political enemies and predicted his disappearance would be explained in time. ${ }^{3}$

${ }^{2}$ Chicago Herald, way 10-14, 1889; Chicago Inter Ocean, May 12, 1889; Hunt, Crime of the Century, pp. 46-56; John T. incEnnis, The Clan-na-Gael and the Hurder of Doctor Cronin (Chicago: F.J. Schulte and J.W. Iliff, 1889), pp. $120-24$.

${ }^{3}$ Chicago Herald, Nay 10, 1889; Chicago Citizen, Nay 11. 18, 1889; Irish-American, Nay 18, 1889; "The Case of Dr. Cronin," p. 130; liunt, Crime of the Century, pp. 117-20. 
The majority of Cronin's friends, however, continued to believe he had been assassinated by Sullivan's followers. The various newspaper reports, they asserted, were all the more reason to suspect there was a vast conspiracy afloat to cover up the murder. They realized that Annie Nurphy, the girl who claimed to have seen Cronin on the street car, was the daughter of Thomas Murphy, a staunch Sullivanite and former senior guardian of Camp 20. Similarly, they contended that Long's reports were inspired by the Triangle, since they contained many details on the internal affairs of the Clan-na-Gael. 4

All speculation as to Cronin's whereabouts ended on May 22, when his mutilated and partially decomposed body was discovered in a Lake View catch basin, less than a mile north of where the bloody trunk had been found. An autopsy revealing several deep gashes in the dead physician's head demonstrated conclusively that he had been brutally bludgeoned to death. 5

Cronin's remains were brought to a Michigan Avenue

${ }^{4}$ Chicago Herald, May 13-14, 16, 19, 1889; Chicago Inter Ocean, May 12, 21, 1889; W. J. Burns to Devoy, May 7 , 1889; Thomas P. Tuite to Devoy, May 8, 1889; John F. Scanlan to Devoy, May 10, 1889; James Clancy to Devoy, May 28, 1889, William O'Brien and Desmond Ryan (eds.), Devoy's Post Bag, 1871-1928 (Dublin: C.J. Fallon, 1948-53), Vol. II, pp. 31113; Hunt, Crime of the Century, pp. 120-25; "The Case of Dr. Cronin," pp. 138-39.

5 Testimony of Francisco Villiers, Henry Rosch, John Fennegan, William Michaels, Captain Wing, and George Waley at the Cronin trial, reprinted in Chicaso Inter Ocean, Oct. 25, 26, 1889; Chicago Herald, May 23, 24, 1889; Chicago Inter Ocean, Nay 23, 1889. 
armory where countless numbers of Chicagoans came to pay their final respects. On Sunday morning, May 26 , the doctor's body was placed in an ornate hearse and driven to Holy Name Cathedral. Thousands of people -- those who admired him, those who still believed he was a British spy receiving his just deserts, and the morbidly curious -- lined the streets for the most impressive funeral Chicago had seen since the death of Stephen Douglas. Ironically, the requiem mass was celebrated by Father Patrick Agnew, brother of Frank Agnew, a loyal Sullivanite. 6

Meanwhile, the police had been busily trying to solve the case. On Nay 23, they received their first major break. While searching the area near the O'Sullivan Ice Company they discovered a vacant cottage, whose blood stained walls and floors clearly indicated it had been the scene of the murder. On questioning Jonas Carlson, the landlord of the cottage, the police learned that a tall, young man using the name Frank Williams had rented the house from March 20 to Way 20. Though he had occasionally stopped off at the cottage, he had never occupied it during the two month period. The landlord knew nothing about the murder, except to say that he had seen Williams outside the cottage on May 4 . He did, however, provide information implicating Patrick O'Sullivan, the proprietor of the ice company, in the crime. While checking on the background of his mysterious tenant, Carlson

\section{${ }^{6}$ Chicarro Herald, Nay 24, 1889; Chicago Inter Ocean,} May 25-27, 1889; Chicago Citizen, June 1, 1889. 
recalled that 0 'Sullivan had told him he knew Williams and could vouch for his character. The police accordingly arrested O'Sullivan, a member of Camp 20 of the Clan-na-Gael, on suspicion of murder.?

Since some of the furniture in the vacant cottage bore the imprint of the Alexander H. Revell Company, police questioned salesmen at that firm to see if they could shed further light on the case. Their records indicated that on February 17, a J. B. Simonds had purchased furniture matching the articles in the cottage, as well as a trunk identical to the blood-spattered one found in Lake View. The goods had been delivered to a South Clark Street flat, located directly opposite the ten-story Chicago Opera. House Building that housed the downtown offices of both Cronin and Sullivan. The agents of the flat admitted that a J. B. Simonds had rented a third-story apartment on February 19, but explained he had moved out a month later, taking all the furniture with him. 8

A few days later the police located an expressman who recalled hauling furniture from the Clark street flat to the vacant Lake View cottage. His description of the man

7 Chicago Herald, May $24,25,1889$; Chicago Inter Ocean, Way 25, 1889; Hunt, Crime of the Century, pp. 158-77.

8 Testimony of W. P. Hatfield, Martin McHale, Fred A. Allen, John J. Neahr, Edward G. Throckmorton, Aaron Goldman, and James J. Marshall at the Cronin trial, reprinted in Chicago Inter Ocean. Nov. 1, 1889; Chicago Herald, inay 26, 1889 ; Chicago Inter Ocean. May 26, 1889; Hunt, Crime of the Century, pp. 177-86. 
who had hired him bore a striking resemblance to Frank WilIiams. The police surmised that the assassins had originally intended murdering Cronin at the Clark Street flat, but had changed their minds and decided that the cottage, situated in a sparsely settled area, was a more suitable location for their grisly enterprise. ${ }^{9}$

Besides trying to track down the tenants of the vacant cottage and the Clark Street flat, the police were also interested in finding the stranger who had called for Cronin on the evening of the murder. The information received on this aspect of the case, however, proved highly embarrassing to the Police Department. Shortly after Cronin's corpse was discovered in the Lake View catch basin, Patrick Dinan, a Clark Street Iiveryman, informed police that on May 4, Daniel Coughlin, a detective assigned to the nearby East Chicago Avenue Police Station, had hired a horse and buggy identical to the rig the stranger had used to drive Cronin to Lake View. He explained, however, that Coughlin himself had not used the buggy but had hired it for a friend from Michigan. When questioned by his superiors, Coughlin, a member of Camp 20, freely admitted having hired the rig but insisted he did not know why his friend had wanted it or what he had done with it. Coughlin added that his friend could not be brought to police headquarters because he had left Chicago, his whereabouts unknown. Coughlin's actions

9 Testimony of Hukon Martensen at the Cronin trial, reprinted in Chicaro Inter Ocean, Nov. 3, 1889; Hunt, Crime of the Century. pp. 190-93. 
appeared extremely suspicious since he was a well-known enemy of Doctor Cronin. A local gangster, for example, reported that Coughlin at one time had offered him money to assault Cronin. The authorities, therefore, formally charged the detective with murder and sent him to the county jail without bail. 10

Since Coughlin had been one of the detectives originally assigned to search for Cronin's body, his arrest came as a shock to most Chicagoans. And if Coughlin was guilty, they wondered to what extent other policemen had been involved in the conspiracy. At the very least, it appeared some of them had been accessories after the fact, for how else could one explain that Cronin's corpse, lying in a catch basin less than a mile from where the bloody trunk had been dumped, had not been discovered earlier. Granted CoughIin certainly had made no effort to find the body, but he was not the only policeman detailed to the case. There is little doubt, for example. that Michael Whalen, Coughlin's partner and fellow Clansman, had helped conceal the crime. Furthermore, it is probable that several other policemen had thwarted the investigation of the case in one way or another; one report noted that approximately one-third of the policemen at the East Chicago Avenue station owed their jobs, dir-

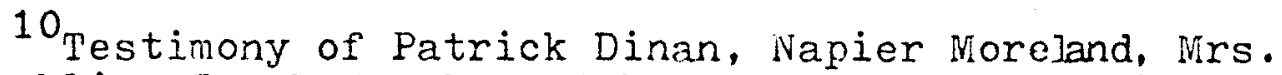
T. T. Conklin, Frank Scanlan, John W. Sampson, and Michael Schaack at the Cronin trial, reprinted in Chicago Inter Ocean, Oct. 27, 29, Nov. 1, 17, 1889; Chicago Herald, May 26-28, 1889; Chicago Inter Ocean, May 29, 1889; Hunt, Crime of the Century, pp. 196-218. 
ectly or indirectly, to the political influence of Alexander Sullivan. At any rate, at least a half dozen policemen at the East Chicago Avenue Precinct were dismissed from the force for their Clan-na-Gael connections. But Irishmen were not the only law officers under suspicion. Rumors floated about that Michael Schaack, Captain at the East Chicago Avenue Station, partially owed his appointment to the Sullivanites and, therefore, had been less than enthusiastic in investigating the case. Schaack, despite a previously outstanding record, was dismissed from the force. 11 On May 28, the day after Coughlin's arrest, the coroner's jury began its investigation of the case. During the next two weeks Coroner Henry I. Hertz and six jurors, none of whom were Irish Catholics, Iistened to Carlson, Dinan, and others testify about events already well-known to the public. Furthermore, several Devoyites, including Luke DilIon, Patrick McGarry, and Thomas F. O'Connor, recounted the "secret" history of the Clan-na-Gael. They described the intense, bitter rivalry that had existed between sullivan and Cronin, and pointed out that since Le Caron's disclosures the previous February, the Sullivanites had been making wild, unfounded charges that Cronin was a British spy. No less than thirteen witnesses testified that Cronin had

\section{${ }^{11}$ Chicago Herald, Nay $24,26,29,31,1889 ;$ Chicago} Tribune, Sept.1,10,11, Dec. 18, 1889; Chicago Inter Ocean, May 23, 27, June 18, Sept. 3, 5, Dec. 18, 20, 1889; Devoy, "The Story of the Clan-na-Gael," Gaelic-American, Jan. 10, 1925. "The Case of Dr. Cronin," pp. 148-49, 159. 187. 
told them he feared Sullivan would arrange to have him murdered. ${ }^{12}$

On June 11, the coroner's jury heard the testimony of the final witness and after a few hours deliberation delivered its verdict, declaring Cronin had been the victim of a Clan-na-Gael conspiracy and that Daniel Coughlin, Patrick o'Sullivan, Alexander Sullivan, Frank Woodruff, and other persons yet unknown were either principals or accessories to the plot. They denounced the Clan-na-Gael, asserting that "all secret societies whose objects are such as the evidence shows that of the 'Clan-na-Gael' or United Brotherhood to be are not in harmony with and are injurious to American Institutions." They also censured the police force for its handling of the case. 13

A few hours after the coroner's jury had delivered its verdict, the police arrested Sullivan, the only one of the four suspects not already in custody. Sullivan, appearing as innocent as an altar boy, spent the next three days on "Murderer's Row" of the county jail, until his attorneys secured his release on $\$ 20,000$ bail. 14

12 Coroner's Inquest Register, Vol. XVII (May-Nov., 1889). Inquest No. 5908, p. 32, MSS in the Vault of the office of the Coroner of Cook County. Testimony of all witnesses reprinted in Chicago Inter Ocean, May 29, 30, June 4-9, 11, 12, 1889.

13 Coroner's Inquest Register, Vol. XVII (May-Nov., 1889). Inquest No. 5908, p. 32 .

${ }^{14}$ Chicago Inter Ocean. June 12, 15, 1889; Hunt, Crime of the Century, pp. 264.-72, 293-300. 
While the coroner's jury was in session, the police uncovered information implicating two other members of Camp 20 in the conspiracy. Through a photograph taken at a Clanna-Gael meeting, Martin Burke, a recent Irish immigrant, was positively identified as the elusive Frank Williams, while Patrick Cooney, whose description resembled that of $\mathrm{J}$. B. Simonds, was suspected of being the tenant of the Clark Street flat. Since both men had left Chicago, police notified authorities throughout the United States and Canada to be on the lookout for them. Cooney was never captured. Burke, however, was less fortunate; on June 17, he was arrested in winnipeg. After lengthy extradition proceedings, he was returned to Chicago in early August. 15

Meanwhile, a special grand jury had been hearing secret testimony and on June 29, indicted seven men for the murder of Doctor Cronin. The indictment of five of these -Coughlin, O'Sullivan, Burke, Cooney, and Woodruff -- had been expected. Woodruff, however, was never tried for the murder, since it had become quite obvious he had no connection with the conspiracy. By mid-June he had made four different confessions, convincing authorities his testimony was completely worthless. Woodruff's role, however, has never been properly explained. There is no doubt he was a psychologically maladjusted eccentric who craved notoriety, but it also seems highly probably that Clan-na-Gael policemen, particularly

15 Chicago Inter Ocean, June $18-23,25$, July $3,4,6$, 26. Aug. 1,6, Dec.17, 1889; Hunt, Crime of the Century, $304-31,357-58$. 
Simon 0'Donnell, who interrogated him, might have helped him invent his original story to convince the authorities that Cronin was still alive. 16

The two other men named in the indictment were John F. Beggs and John Kunze. The grand jury believed that in early February, 1889, Beggs, the Senior Guardian of Camp 20, had appointed a secret committee headed by Coughlin that had planned and carried out Cronin's execution on the grounds he was a British spy. Beggs, a prominent Republican politician had the distinction of leading a delegation of IrishAmericans to visit Benjamin Harrison in Indianapolis during the 1888 presidential campaign. In early 1889, he had conferred with the President-elect on matters of political patronage. Naturally, his arrest was a source of embarrassment for the Harrison administration. 17

While the indictment of Beggs had been expected in some quarters, the news that Kunze, a German immigrant, was apparently involved in the conspiracy came as a surprise to most Chicagoans. Kunze, it seems, had met Coughlin while the latter was investigating a criminal case and the two had quickly become friends. Certain witnesses testifying before the grand jury stated they had seen Coughlin and Kunze

\section{${ }^{16}$ Chicago Inter Ocean, June 30, 1889; Devoy, "Story} of the Clan-na-Gael," Gaelic-American, Jan. 10, 1925; "The Case of Dr. Cronin," p. 131; Hunt, Crime of the Century, pp. 289-91.

17 Chicago Inter Ocean, Dec. 17, 1889; Testimony of Daniel J. Lyon at the Cronin trial, reprinted in Chicago Inter Ocean, Nov. 21, 1889; Chicazo Tribune, Sept. 16, 1888; Hunt, Crime of the Century, pp. 358-61. 
together on several occasions during the previous spring, and one claimed he had spotted them outside the Lake View cottage on the evening of the murder. 18

Alexander Sullivan's name, however, was conspicuously absent from the indictment. Though sufficient to convict him in the court of public opinion, the evidence against him was far too inconclusive to stand up in a court of law. Trianglers in Chicago and throughout the United States, as well. as Irish leaders like Parnell and Davitt, who had stood by Sullivan, no doubt breathed a sigh of relief that the former President of the Irish National League of America had been legally exonerated from one of the most gruesome crimes of the decade. ${ }^{19}$ But to the Devoyites, convinced that Sullivan was the mastermind behind the whole plot, the grand jury's decision came as a bitter blow. During the previous weeks the Devoyites had been conducting a vigorous campaign against their arch enemy and $h$ is supporters. They and other friends of Cronin had established the Cronin Committee to unearth the roots of the conspiracy. It was this committee that first had discovered the spurious nature of Long's Toronto dispatches, dispatches that were eventually traced to the Triangle. The Devoyites also raised money to aid the

\section{${ }^{18}$ Chicago Inter Ocean, July 2, 3, Dec. 17, 1889;} Hunt, Crime of the Century, pp. 367-68.

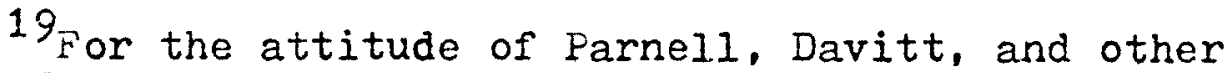
Irish leaders, as well as that of pro-Sullivan Irish-Americans see Irish World, June 22, 29, July 6, 13, 1889, IrishAmerican, June 29, July 6, 1889, Chicago Inter ocean, June 18, 1889; McEnnis, The Clan-na-Gael, p. 147 . 
prosecution of the case and held public meetings to voice their indignation of the Sullivanites. 20 For example, on August 15, they sponsored a rally at Cheltenham Beach in opposition to the Triangle picnic at Ogden's Grove. Several speakers, including P.W. Dunne and Devoy, thoroughly excoriated the Sullivanites as thieves and murderers, using the sacred cause of Ireland to further their own selfish ends. Father Toomey, a downstate priest, declared.

The hanging of the actual murderers will not reach the root of the crime. That will only be reached when the man with fertile brain and inventive genius who engineered the crime while his pockets were filled with the money plundered from the Irish people shall be brought to justice. (Cheers and cries of "Sullivan! Sullivan!")

It is to this arch traitor that you want to look, and it is to him and his henchmen that you must look. You must look to men who can spend money like water, men who have no vocation or calling which will bring them in the sums which they spend. It is men who can spend $\$ 25,000, \$ 50,000$, or $\$ 75,000$ a year, and who murder men to cover it up. (Tremendous cheers and cries of "Sullivan! Sullivan!" and "That's the talk!") These are the men that you want to see dance upon nothing (wild cheers and cries of "That's the talk! Hang him! Hang him!") rather than the men who have been deceived and duped into committing crime for which doubtless to-day they are sorry. 21

${ }^{20}$ Chicago Tribune, May 29, Oct. 28 , Nov. 11,24, 1889: Chicago Inter Ocean, Nay 23, 24, Aug. 8, 11, 1889; Irish-American, Oct. 25, 1889; Devoy, "Story of the Clan-naGael," Gaelic-American, Feb. 21, 28, 1925. See also John $P$. Scanlan to Devoy, May 10, 1889; James Clancy to Devoy, May 28, 1889, Devoy's Post 3ag, Vol. II, pp. 312-14. ${ }^{21}$ Chicago Inter Ocean, Aug. 16, 17, 1889; Hunt. 
In their campaign against the Triangle the Devoyites received the wholehearted support of prominent Protestant Americans. Throughout the months preceding and during the trial, reform-minded newspaper editors, particularly William Penn Nixon of the Inter Ocean, waged a vigorous crusade against the Sullivanites. Civic-minded Americans also appeared alongside Irishmen at anti-Triangle demonstrations. On June 29, for example, over 3,000 persons -- Irishmen, Americans, Germans, and others -- gathered at a rally of the Personal Rights League to hear several leading citizens denounce the murder of Doctor Cronin. Among those speaking were Robert Lindbolm of the Board of Trade and Louis Nettlehurst of the Board of Education, as well as Irishmen like Devoy and Colonel W. P. Rend. 22

The alliance between the Devoyites and the reformers, however, was in many respects an uneasy one. Though both groups detested Sullivan, their motives for doing so were essentially different. The Devoyites were primarily interested in removing Sullivan's influence from Irish-American affairs. They continually emphasized that the Trianglers were merely a corrupt faction of the Clan-na-Gael and that the organization as a whole was not responsible for the murder. The aims of the Clan, they contended, were noble and

Crime of the Century, p. 380 .

22 Chicago Inter Ocean, June 29, July 3, 1889; Devoy, "Story of the Clan-na-Gael," Gaelic-American, Jan. 17, 1925; Hunt, Crime of the Century, pp. 369-78. 
in complete harmony with American principles. 23 The reformers, on the other hand, conveniently overlooking the fact that the Devoyites were also Clansmen, denounced the Clanna-Gael as a secret, oath-bound, foreign society that threatened the very fabric of American life. ${ }^{24}$ Comparisons between the Cronin murder and the Haymarket Square Riot of 1886 (both ironically occurred on May 4) were quite common. The Inter Ocean, for example, declared that "in each case the motive power was contempt of American law and purpose to make the will and decrees of a secret cabal supreme over the lives and fortunes of American citizens." 25 But some reformers seemed to consider the Sullivanites far more dangerous than the Anarchists, since they were so thoroughly entrenched in the local government and the police department. 26 Though the reformers occassionally descended to the level of anti-Irish nativism, they generally concentrated their attacks on Sullivan and the Clan-na-Gael, insisting that Irish-Americans as a group were not responsible for the Cronin murder. 27 No doubt, had Cronin been anything other

\section{Luke Dilion, et. al. to the American Friends of} Ireland and Lovers of Justice, June 26, 1889, Devoy's Post Eag, Vol. II, pp. 314-16; Chicago Tribune, Oct. 21, 1889; Chicago Inter Ocean, May $28,31,1889$.

${ }^{24}$ Chicago Tribune, June 12, Sept. 13, 1889; Chicago Herald, May 29, 1889; Chicago Inter Ocean, May 29, 30, 1889.

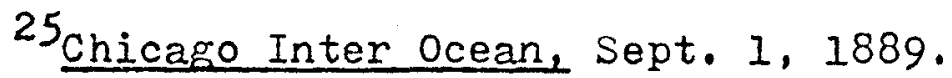

${ }^{26}$ Chicago Tribune, Sept. 11, 1889; Chicaso Inter Ocean, Sept.1,1889.

27 Chicago Inter Ocean, Nay 30, June 7, 1889; Chicago Citizen, Aug. 10, 1889. 
than an Irish Catholic, the reaction against the Irish community would have been far more intense. As it was, nativists used the Cronin murder to attack the loyalty of IrishAmericans and the concept of unrestricted immigration. 28 Although no great wave of nativism followed in the wake of the Cronin murder, most Irish Chicagoans realized the crime had struck a severe blow to their claims for respectability. 29 They were extremely sensitive to attacks on Sullivan and the Clan-na-Gael. Finerty, for instance, denounced the reformers as anti-Irish bigots, claiming they were using the Cronin murder "to blackguard, and, if possible, to permanently injure the race to which he Cronin belonged and the cause that he championed." 30 He pointed out it was possible British spies might have killed Cronin, but that even if Irishmen were guilty, Sullivan and the clan-na-Gael should not be held accountable. 31 similarly, at the Clan's annual August 15 picnic in Ogden's Grove, Finerty and other speakers re-asserted the loyalty of IrishAmericans to the United States. They reminded the audience that Irish-Americans had helped defend the nation in several wars and that Irish policemen had fought gallantly to preserve law and order during the Haymarket Square Riot. A res-

${ }^{28}$ Chicago Inter Ocean, June $24,1889$.

${ }^{29}$ Chicaso Citizen, June 1, July 6, 1889; McEnnis, The Clan-na-Gael, p. 145 .

${ }^{30}$ Chicago Citizen, July 6,1889 . See also Chicago Citizen, June 8,22, oct. 12, Nov. $30,1889$.

${ }^{31}$ Chicago Citizen, June 1,8 , July $6,1889$. 
olution condemning the Cronin murder was passed at the Ogden's Grove rally -- but there was wild cheering every time Sullivan's name was mentioned. 32

On August 30, just two weeks after the Ogden's Grove picnic, the long awaited trial of o'Sullivan, Coughlin, Burke, Beggs, and Kunze began in the Criminal Court of Cook County. State's Attorney Joel Longenecker acted as chief prosecutor with assistance from three other prominent attorneys, including William J. Hynes, Sullivan's bitter foe. William S. Forrest, one of the best criminal lawyers in the Midwest, led a battery of seven attorneys for the defense. The fees for the defense came largely from a special fund established by the Clan-na-Gael. 33

The first task before the court was the selection of a jury, a process that took almost two months. Over one thousand veniremen were disqualified because they had either formed a definite opinion on the case or were prejudiced against the Clan-na-Gael. The twelve jurors finally selected were all native American Protestants. The Irish, therefore, had a legitimate complaint that the jury was unrepresentative of the heterogenous population of Cook County. 34

32 Chicago Citizen, Aug. 24, 1889; Chicago Inter Ocean, Aug. 16,1889 .

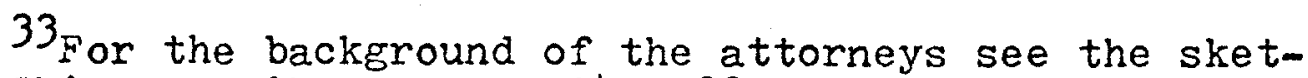
ches in Chicago Tribune, Oct. 24, 1889; "The Case of Dr. Cronin," pp. 243-44. For the defense fund see Chicago Tribune, Sept. 12, 22, oct. 15, Nov. 11, 18, 24, 1889; Chicago Inter ocean, Sept. 14, Nov. 3, 4, 1889; Chicago Citizen. Nov. 9, 16, 23, 1889.

${ }^{34}$ Chicago Tribune, oct. 23,1889 , Chicago Citizen, 
The long dreary procedure of selecting a jury was interrupted by the spectacular news that there had been an attempt to $f i x$ the jury. In mid-october, seven men, including two Clansmen and John Graham, a clerk in the law office of A. S. Trude, Sullivan's attorney and close friend, were arrested for complicity in the plot. Since Graham and two Clansmen were involved, few Chicagoans doubted that Sullivan and his machine were behind the whole scheme. Sullivan's enemies hoped the testimony at the jury bribers' trial would implicate him in the plot. Such evidence, however, was never forthcoming. Graham jumped bail before the trial began the following February. The two Clansmen stood trial but said nothing to incriminate sullivan. 35

After nearly two months spent selecting a jury, the actual trial began on October 24 . The prosecution presented a fairly damaging case against Burke, Coughlin, and o'Sullivan. Witnesses identified Burke as the tenant of the Lake View cottage and Coughlin as the man who had hired the rig used to take Cronin to his death. The testimony against o'Sullivan was equally incriminating. The state showed that he had signed a medical contract with Cronin less than a fortnight before the murder. This, coupled with the fact that it seemed highly unusual that he had hired Cronin instead of a nearby physician in Lake View, convinced most

oct. $26,1889$.

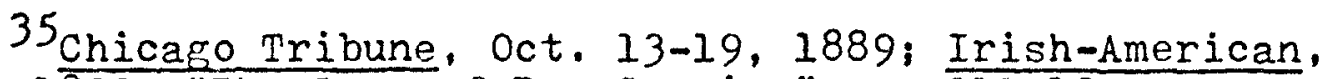
Feb. 15, 1890; "The Case of Dr. Cronin," pp. 311-13. 
people that he had signed the contract to lure Cronin to the vacant cottage near his ice company. 36

The case against Kunze was considerably weaker.

Though one witness claimed to have seen the young German outside the Lake View cottage on the evening of the murder and another recalled having seen $\mathrm{him}$ in the Clark Street flat, their testimony seemed suspect, since it appeared unlikely they could have remembered so vividly a stranger they had seen only once. Furthermore, the prosecution failed to show any motive for Kunze's part in the conspiracy or why an Irish secret society would have permitted a German immigrant to partake in such an enterprise. 37

In its case against Beggs, the state had little difficulty in showing that on February 8, 1889, the Senior Guardian of Camp 20 had appointed a secret committee whose ostensible purpose was to investigate Doctor Cronin's charges against the Triangle. However, the prosecution was on far more shallow ground when it tried to prove that the committee's real function was to arrange Cronin's execution. Though several witnesses testified that Beggs had made a number of hostile remarks about cronin, it failed to offer

36 Testimony of T. T. Conklin, Mrs. T. T. Conklin, Frank Scanlan, Frank Murray, Laura Hermann, Patrick McGarry, Annie Carlson, Jonas Carlson, Charles Carlson, Johanna Carlson and Hukon Martensen at the Cronin trial, reprinted in Chicaso Inter Ocean, Oct. 29-31, Nov. 2, 3, 8, 1889.

37 Testimony of William Mertes at the Cronin trial, reprinted in Chicago Inter Ocean, Nov. 8, 1889, Hunt, Crime of the Century, p. 446 . 
any convincing evidence that the committee had in fact planned the murder. 38

After more than three weeks of testimony the prosecution rested and the defense began its case. Numerous witnesses provided alibis for O'Sullivan, Burke, and Coughlin, but since they were either friends or relatives of the defendants their testimony seemed highly questionable. The defense also called several medical and scientific experts who tried to show there was no positive proof that Cronin had died from head wounds as charged in the indictment or that he had been killed in the vacant cottage. 39

The trial finally ended on December 16, when the jury, after deliberating for seventy hours, delivered its verdict: Beggs was acquitted; Kunze was found guilty of manslaughter and sentenced to three years in prison; and o'Sullivan, Coughlin, and Burke were convicted of murder and sentenced to the penitentiary for life. 40

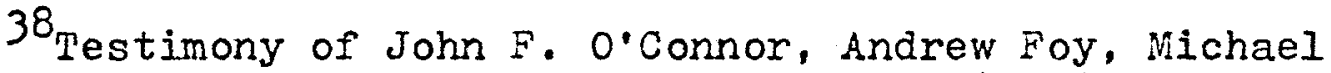
J. Kelly, Anthony Ford, Stephen Colleran, Dennis O'Connor, Patrick H. Nolan, Thomas $F$. O'Connor, Henry 0 . O'Connor, John M. Collins, Patrick IAcGarry, Joseph C. O'Keefe, Cornelius Flynn, and Edward Spellman and Longenecker's final argument at the Cronin trial, reprinted in Chicago Inter Ocean, Oct. 30, 31, Nov. 1, 5, 30, Dec. 1, 1889.

39 Testimony of James Hyland, Jeremiah Hyland, Michael Whelan, John Stift, Redmond McDonald, William ivulcahy, Thomas Whelan, Robert Boyington, James Knight, James Minnehan, Kate McCormick, Annie Whelan, Matthew Danahy, Villiam F. Coughlin, John $\vec{F}$. O'Malley, Marshall D. Ewell, Dr. H. M. Moyer, Dr. Lester Curtis, Dr. Edmund Andrews, and Dyer Thompson at the Cronin trial, reprinted in Chicago Inter Ocean, Nov. 19-23, 26. 1889.

\section{0}

Chicago Inter Ocean, Dec. 17, 1889. 
On the whole, Triangle supporters were pleased with the verdict. Finerty declared that Beggs' acquittal vindicated the Clan-na-Gael since it destroyed the prosecution's theory of a conspiracy in Camp 20. He also contended that Beggs' acquittal and Kunze's light sentence showed that the jury must have had "lingering doubts" about the guilt of the other three defendants. 41 Similarly, Ford's Irish Norld expressed gratification "that the spirit of the law . . and race hatred have been repudiated as unequal to the test of judicial inquiry." 42 The sullivanites, of course, were disappointed O'Sullivan, Coughlin, and Burke had received terms of Iife imprisonment, but they could take solace in the fact that none of them would be hanged and that the verdict might be overturned on appeal. Though 0 'Sullivan was downcast after the verdict, Burke and Coughlin seemed to be in fairly good spirits. 43

Conversely, many Devoyites and reformers considered the verdict a travesty of justice. They failed to understand how the jury could convict O'Sullivan, Coughlin, and Burke of murder but yet fail to impose the death penalty. They had hoped that if some of the defendants were sentenced to death, they might talk and reveal Sullivan's connection with the crime. But with the possibility of a successful appeal,
${ }^{41}$ Chicago Citizen, Dec. 21, 1889.
42 Irish World, Dec. 21, 1889.
${ }^{43}$ Chicago Tribune, Dec. 17, 1889. 
they realized there would be no confessions. They took some comfort, however, in the fact that at least three of the culprits would probably spend the rest of their lives in prison. 44

Immediately after the jury had delivered its verdict, the defense entered a plea for a new trial. On January 14 , 1890, the court listened to defense arguments but refused to reverse the verdict against O'Sullivan, Coughlin, and Burke. The judge, however, ordered a new trial for Kunze, declaring his conviction was absurd in view of the lack of evidence against him. The state never attempted to try him again. 45 Undaunted by the adverse decision, the defense began appeal proceedings before the Illinois supreme Court. But before the high court handed down a decision, both Burke and O'Sullivan had died, in each case from tuberculosis. Since they were young, healthy men on entering the penitentiary, inhumane prison conditions had undoubtedly contributed to their deaths. Though prison authorities had made several attempts to get them to make confessions, both men died with their lips sealed on the Cronin murder. Burke and O'Sullivan, however, were not the only individuals involved in the case to die within a few years after the murder. Beggs, Woodruff, and a few of the witnesses at the trial also died.

\section{${ }^{44}$ Chicago Tribune, Dec. 17, 1889; Chicago Inter}

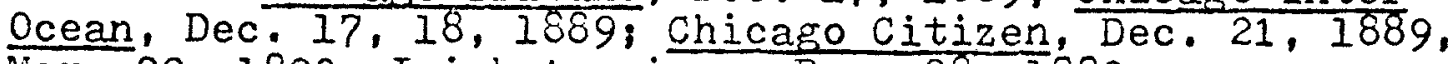
Mar. 29, 1890; Irish-American, Dec. 28, 1889.

45"The Case of Dr. Cronin," pp. 308-09, 313: Chicago Inter Ocean, Jan. 15, 1890. 
There is no reason to suspect that these deaths were anything more than a coincidence, although many Chicagoans believed the mysterious hand of fate was behind them all. 46 Fate was kinder to Dan Coughlin. On January 19, 1893, the Illinois Supreme Court granted him a new trial on the grounds that two of the jurors had been biased against the defendants. 47 This decision, however, had further ramifications than the Cronin case. When granting a pardon to the imprisoned Anarchists later that year, Governor John Altgeld referred to Coughlin v. the People of the State of Illinois in his argument that a biased jury had prevented them from getting a fair and impartial trial. It was ironic that the Cronin case, so frequently compared to the Haymarket Square Riot, was in the end partially instrumental in the release of the Anarchists. 48

Soon after the high court's decision, Coughlin was returned to Chicago to stand trial once again for the murder of Doctor Cronin. After considerable delay the second trial began on November 30, 1893 in the Criminal Court of Cook County. The first month was spent in selecting a jury. The second panel, unlike the first, included one Irish Catholic, but he supposedly had no connections with the Clan-na-Gael.

${ }^{46}$ Chicago Tribune, Dec. 11, 1893; Irish-American, June 20, 1891; "The Case of Dr. Cronin," pp. 314-15. ${ }^{47}$ Coughlin v. The People of the state of Illinois, 144. III. 140 (1893). 48 Ernest B. Zeisler, The Haymarket Riot (Chicago: Alexander J. Isaacs, 1956), p. 83. 
There were several rumors of jury tampering throughout the trial. Though nothing conclusive was ever proved, it seems highly possible that some of the jurors were indeed bribed. 49 The prosecution began its case on December 11, with an opening argument by Assistant State's Attorney Bottum. Since Beggs had been acquitted, the state was forced to present a somewhat different theory of the conspiracy. Instead of claiming the Senior Guardian of Camp 20 had appointed a secret committee headed by Coughlin, the prosecution now contended that higher officials in the Clan had sent Coughlin a letter requesting he arrange Cronin's execution. 50 Though the majority of its witnesses had testified at the first trial, the prosecution called a few new witnesses, the most spectacular of whom was the estranged wife of Andrew Foy. Foy, a fanatic Sullivanite and member of Camp 20, had been summoned to testify at the previous trial but had never been suspected as an actual accomplice in the murder. But Mrs. Foy now claimed that her husband and Coughlin had held several meetings during which they had planned Cronin's murder. On cross-examination, however, the defense severely undermined Mrs. Foy's testimony. Coughlin's attorneys produced evidence indicating that Mrs. Foy had been bribed by Cronin's friends and that she was an unstable

${ }^{49}$ Chicago Tribune, Dec. 30, 31, 1893, Jan. 19, Feb. 25-28, Mar. 9, 1894; "The Case of Dr. Cronin," pp. 317-19.

50 Bottum's opening argument reprinted in Chicago Tribune, Dec. 12, 1893; "The Case of Dr. Cronin," pp. 319-21. 
woman, using the court to take revenge on her husband. Though a good deal of Mrs. Foy's testimony could have been true, it must be admitted she appeared to be less than a credible witness. After cross-examination, it is difficult to see how any fair-minded juror could have used her testimony as a basis for sending a man to the gallows. 51

The defense also presented a few new witnesses, including John Kunze, one of the defendants at the previous trial, but in no instance did they produce any new dramatic evidence. The trial finally ended on March 8, when the jury, after deliberating only five hours, delivered a verdict of not guilty. 52

Despite the verdict, most Chicagoans believed CoughIin was guilty. But the newspapers, in sharp contrast to their reaction after the first trial, were only mildly disturbed. The Tribune, for instance, stated that while it was possible some of the jurors had been bribed, it was unlikely that all of them had been on the Clan-na-Gael payroll. The Pribune theorized that the jury might have been swayed by the judge's final instructions, which were quite favorable to the defense, and by the pitiful sight of Coughlin's wife and two small children who had been present in the courtroom every day. The rather casual attitude of the local press

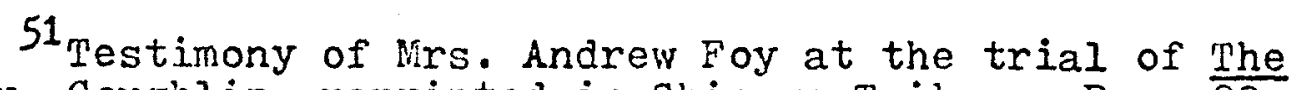
People v. Coughlin, reprinted in Chicago Tribune, Dec. 23 , 52 Chicago Tribune, Mar. 9, 1894. 
merely reflected the apathy most Chicagoans felt toward the case. 53 Five years and several more murders, including the assassination of Mayor Carter H. Harrison I, had done much to blunt their memory of Doctor Cronin and the lonely Lake View cottage. In this rapidly changing city where the past was quickly forgotten, five years seemed like a century. The Devoyites, still seeking revenge, were indeed crying in the wilderness.

After the trial Coughlin went to his boyhood home in Hancock, Michigan, for a brief period but then returned to Chicago, where he opened a saloon and became one of the leading members of a jury bribing ring. In 1899, the authorities finally caught up with him and arrested him for jury tampering. He jumped bail, however, and fled to Honduras, where he worked for the United Fruit Company under the name of James E. Davis. He died on December 29, 1910.54

There has never been a full and satisfactory explanation of all the events surrounding the Cronin murder. One of the more plausible theories was put forward by John T. McEnnis, a Sullivanite Clansman, newspaper reporter, and author of The Clan-na-Gael and the Murder of Doctor Cronin. McEnnis speculated that certain members of the Clan-na-Gael had decoyed Cronin to the Lake View cottage in an effort to force him to hand over the anti-Triangle minority report on

\footnotetext{
${ }^{53}$ Chicago Tribune, Mar. 9, 10, 13, 1894. 54"The Case of Dr. Cronin," pp. 337-41, 359-61; Chicago Daily News, April 9, 1909.
} 
the 1888 trial, which he always carried in his breast pocket. McEnnis surmised that Cronin had tried to resist and had been killed in a subsequent fight. In arguing his case McEnnis made several good points. If the conspirators had planned to murder Cronin, he contended, they would have found a less sloppy way of killing him than hitting him with an assortment of weapons from an ice pick to a broken arm of a rocking chair. He also claimed that had they intended to assassinate Cronin, they would have made better preparations for disposing his body. No man in his right mind, McEnnis asserted, would have dumped the corpse in a sewer where it could be easily found. The major flaw in this argument, however, is that there seemed to be little logic in taking Cronin's report since there were other copies of it in existence. 55

In contrast to McEnnis, the Devoyites contended that Sullivan had indeed intended to murder Cronin. They asserted that Sullivan, facing possible ruin in both local politics and Irish-American affairs, had formulated an ingenious plan to remove cronin and at the same time discredit him. According to this theory, Sullivan and his henchmen had planned to kill Cronin, remove his clothes, and dump his body in the middle of Lake Michigan where it would never be found. It would thus appear that Cronin had not been murdered but had simply disappeared. The Devoyites claimed that all the phony reports of persons seeing Cronin alive were designed

\section{McEnnis, The Clan-na-Gael, pp. 146-47, 162-63.} See also Devoy, "Story of the Clan-na-Gael, Gaelic-American. Feb. 28, 1925. 
to lend credence to this theory. They further asserted that the Sullivanites had intended to ship Cronin's clothes to England where their confederates would place them on a corpse similar to Cronin's. They would then put documents in the pockets showing he was a British spy, and throw the corpse along a bank of the River Thames. When discovered, it would thus appear that Cronin had gone to London to testify against Parnell but had been assassinated by Irish nationalists before getting the chance. 56

Later accounts by Finley Peter Dunne and Devoy help to clear up some of the mystery surrounding the murder, but still leave many questions unanswered. Dunne, in an essay marred by certain factual errors, claimed that Coughlin was responsible for organizing the plot and that Sullivan knew nothing about it until after it was completed. However, according to Dunne, Sullivan, out of a sense of loyalty, tried to shield Coughlin and the others following the murder, and was, therefore, an accessory after the fact. 57

On the other hand, Devoy, in his Gaelic-American articles, contended that Sullivan was responsible for the murder, though he made no attempt to claim he had actually organized the conspiracy. Instead he argued that Sullivan

${ }^{56}$ Diary of John Devoy, Devoy Papers, MSS 9819, National Library of Ireland; Chicago Tribune, Sept. 16, 1889; "The Case of Dr. Cronin," pp. 363-64.

57 F. P. Dunne, Mr. Dooley Remembers: The Informal Memoirs of Finley Peter Dunne, Edited by Philip Dunne (Boston, Little, Brown, and Co., Atlantic Monthly Press Book, 1963), pp. 69-81. 
had spread the story that Cronin was definitely a British spy. Sullivan, Devoy asserted, had known full well that such an accusation would result in Cronin's murder. In this way he would not be involved directly in the crime but would achieve his purpose nonetheless. 58

Through interviews with Mrs. Foy and other friends and relatives of the murderers, Devoy learned that Coughlin had supervised the plot, but that the fatal blows had been delivered by Cooney, Burke and Foy. In later jears Devoy felt little animosity toward these men, since he was convinced they had been duped by Sullivan. Devoy also mentioned that he believed O'SuIlivan had been unaware the others planned to kill Cronin but had thought they simply intended to take the anti-Triangle minority report away from him. He also stated that neither Beggs nor Kunze were involved in the crime; Kunze, he said, resembled Foy and had thus saved him from arrest in 1889. Finally, Devoy also gave a satisfactory answer to McEnnis' argument that had the conspirators really intended to murder Cronin they would have done it in a less haphazard fashion. He asserted that prior to and after the murder the perpetrators had been drinking heavily and thus were not in the right frame of mind to know exactly what they were doing. 59

${ }^{58}$ Devoy, "Story of the Clan-na-Gael," Gaelic-American. Feb. $14,28,1925$.

59 Devoy, "Story of the Clan-na-Gael," Gaelic-American, Feb. 14, 28, 1925. 
If Devoy's account is correct, it is clear that despite all the time and money the state spent on the Cronin case, the interests of justice were not served. At least three of the conspirators, Cooney, Foy, and the unidentified driver of the horse and buggy, were never punished for their part in the crime, while Coughlin, the ring leader, served less than four years in the penitentiary. On the other hand, two innocent men, Beggs and Kunze, though eventually acquitted, had to suffer the ordeal of being tried for a capital offense. And O'Sullivan, unaware of the true nature of the plot, met an early death in prison. Burke, alone, received his due.

The Cronin murder naturally had serious repercussions on Irish-American affairs. First of all, it effectively destroyed the fragile unity that had existed in the Clan-naGael since the Chicago Convention of June, 1888. A few months after the murder, the four Devoyite members of the Clan Executive Committee called a convention for the purpose of "purifying" the Clan-na-Gael. However, the four Triangle members (the fifth, Patrick Egan, had resigned in May, 1889, to take up his duties as United States Minister to Chile), bitterly opposed the convention and warned all camps not to send delegates to what they considered an unauthorized gathering. Nonetheless, delegates from some eighty-five Devoyite camps met in Philadelphia in November, 1889. They elected a new nine-man Executive Committee and voted to sever connections with all Triangle camps. They also requisitioned 
$\$ 1,000$ to aid the prosecution in the Cronin case. Thus, once again there were two rival Clan-na-Gael organizations. During the $1890^{\prime} \mathrm{s}$ the Clan was moribund, as many rank and file members, disgusted with the continued factionalism, drifted out of the movement. The division lasted until 1900 when, after considerable negotiation, both sides agreed to merge at a convention in Atlantic City. Several old antagonists, including Devoy and Finerty, patched up their differences at that convention. Sullivan, however, having retired from clan affairs on the national level during the $1890^{\circ} \mathrm{s}$, was not present. His absence, no doubt, helped to smooth the path toward unity. 60

The Cronin murder also exacerbated the already embittered relations between the Trianglers and their enemies in the Irish National League of America. In the latter months of 1889, several Devoyites and conservatives hinted that the League's Treasurer, Father Charles O'Reilly of Detroit, had become the dupe of the Sullivanites and was allowing League money to be used for the defense fund in the Cronin case. They demanded that President Fitzgerald call the long overdue national convention, which would make a thorough examination of the League's financial records. Fitzgerald, however, refused to call a convention on the grounds that Par-

${ }^{60}$ Chicago Tribune, Sept. 19, Oct. 7, 13, Nov. 25, 28, 1889; Chicago Inter Ocean, July 24, 1889; Diary of John Devoy, Devoy Fapers, iisS 9819, 9820, National Library of Ireland; Devoy, "Story of the Clan-ra-Gael," Gaelic-American, Mar. 21, 28, April 4, 11, 18, 25, hay 2, 30, June 6, 1925. "The Case of Dr. Cronin," pp. 343-49. 
nell opposed it. Since the prosecution at the recent Special Commission had accused him of being in league with Irish-American revolutionaries, Parnell was rather reluctant to sanction a convention that might conceivably pass resolutions favoring violence and, therefore, throw further suspicion on him. Parnell also realized that the intense factional fighting, bound to occur at such a gathering, would only serve to harm the Irish cause. 61

Though Fitzgerald refused to summon a convention, he did appoint a Triangle-dominated committee to audit the League's accounts. The committee, meeting in Detroit in January, 1890, exonerated O'Reilly and found the League's financial records to be in order. This, however, failed to satisfy the Devoyites and the conservatives. Claiming the committee's audit had been merely a whitewash, they pressed for a convention that would thoroughly investigate the League's financial affairs. ${ }^{62}$ The conservative IrishAmerican, for example, demanded a convention, declaring that in this case the League officials should not follow the dictates of the Irish leaders, since they had no right to interfere in the internal affairs of Irish-Americans. ${ }^{63}$ Fitzgerald,

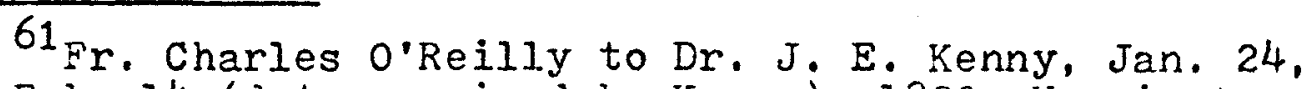
Feb. 1, Feb. 14 (date received by Kenny), 1890, Harrington Papers, MSS 8582, National Library of Ireland; Irish-American, June 8, 15, 22, 29, 1889, July 12, 1890; Peter VicCahey, Letter to the Editor, Irish-American, June 29, 1889; Irish World, June 22, 1889, Chicaso Citizen, Feb. 1, 8, 1890: Chicago Inter Ocean, July 24, 1890.

62 Irish-American, Feb. 1, 8, 15, May 24, July 19. 1890, Chicago Citizen, Feb. 8, 1890. 63 Irish-American, Feb. 8, May 10, June 7, 1890. 
however, refused to call a convention without Parnell's approval.

In April, 1890, the National League received a severe blow when Hugh McCaffrey and Father Patrick A. McKenna, respectively First and Second Vice-Presidents of the League, resigned, claiming that the organization was run by a band of western political opportunists. For all practical purposes, they asserted, the League was dead. John Boyle

$0^{\prime}$ Reilly, in a somewhat more charitable tone, suggested that perhaps the League had indeed outlived its usefulness and should be allowed to die. Parnell apparently agreed. In May, 2890, John Dillon, writing for Parnell, informed League officials that internal political bickering had made the central organization more of a nuisance than anything else, and requested that local American branches no longer forward their money to Father $0^{\prime R e i l l y}$ but send it directly to Dublin. The American leaders, embittered with Farnell's decision, nonetheless reluctantly complied with his request. 64 In the autumn of $1890 \mathrm{six}$ Irish M. P.'s arrived in the United States to raise money for the evicted tenants in Ireland. Refusing to become involved in the internal disputes of Irish-Americans, they impartially attended demon-

$64 \mathrm{Fr}$. Charles 0'Reilly to Dr. J. E. Kenny, June 25, Aug. 9, 1890, Harrington Papers, MSS 8582, National Iibrary of Ireland; Irish-American, May 3, 10, Sept. 13, 0ct. 4, 1890; Editorials from Boston Pilot reprinted in Irish-American, Nay 17, 31, 1890; Chicago Citizen. Augl 16, 1890; Thomas N. Brown, "Irish-American Nationalism, 1848-1890," (Ph. D. Dissertation, Harvard University, 1956), p. 335. 
strations sponsored by both the Trianglers and their enemies. Despite the rampant factionalism in Irish-America, the Irish envoys had a remarkably successful tour. Their campaign, however, came to an abrupt halt after only a few weeks, when news of the Parnell-0'Shea divorce scandal struck like a bolt of lightning on Irish nationalists on both sides of the Atlantic. On November 17, 1890, Captain William 0'Shea was granted a divorce from his wife on grounds of adultery. Parnell, named as a correspondent, refused to contest the case, thereby virtually admitting his guilt. At first the Irish Parliamentary Party stood solidly behind Parnell. But when Gladstone, under pressure from his Non-conformist constituents, demanded that Parnell step down as leader, and Parnell refused to comply, the Irish Party was faced with the difficult decision of either choosing their chief or the Iiberal alliance, an alliance vital to the success of Home Rule. During the first six days of December, 1890 , Irish M. P.'s met in the now famous Committee Room Fifteen of the House of Commons. At the end of their deliberations only twenty-eight members stood by Parnell. The majority opted for Gladstone and dumped Parnell. They elected Justin McCarthy as their leader and established the Irish National Federation as a rival to the Irish National League, still headed by Parnell. 65

${ }^{65}$ Irish-American, Oct. 25, Nov. $15,22,29$, Dec. 6 , 13, 1890; Chicago Citizen, Dec. 6, 1890; Timothy Harrington to (?) Hishom, Nov. 25, 1890, Harrington Papers, MSS 8582, National Library of Ireland; Brown, "Irish-American Nationalism, 1848-1890," pp. 341-42. For a history of the split 
As in other matters, Irish-Americans split on the issue of Parnell's leadership. Most conservatives, convinced that no man was more important than Home Rule, sided with the anti-Parnellites. In May, 1891, members of the Hoffman House Committee and leading conservatives from the Irish National League met in New York and formed an American affiliate of the anti-Parnellite Irish National Federation. In contrast to the conservatives, most Devoyites supported Parnell, believing that an English political party had no right to dictate who the Irish leader should be. Parnell's revolutionary tinged rhetoric during the North Kilkenny by-election in December, 1890 also no doubt helped to win him friends among the Devoyite wing of the Clan-naGael. 66

Reaction among the Trianglers was mixed. Most Sullivanite Clansmen in New York backed Parnell, as did western leaders like Finerty and Michael Gannon. Sullivan also leaned toward Parnell, though he made no real effort on his behalf. Some Trianglers, however, supported the anti-

in the Irish Parliamentary Party see F. S. L. Lyons, The Fall of Parnell, 1890-91 (London: Routledge and Kegan Paul, 1960).

${ }^{66}$ Irish-American, Dec. 20, 27, 1890, Mar. 21, 28, April 4, May 30, June 6,20 , July 25 , oct. 10, Nov. 21, 28, 1891; Chicago Citizen, Dec. 20, 1890; Devoy to J. J. O'Kelly, n. d. (probably Nov, or Dec., 1890); Michael Breslin to Devoy, Jan. 8, 1891; William Redmond to Devoy, June 5, 1891, Devoy's Post Bag, Vol. II, pp. 316-17, 319, Patrick McGarry to John Dillon, July 23, 1896, Edward Flaherty to John Redmond, July 27, 1896, Harrington Papers, MSS 8577, National Library of Ireland; Devoy, "Story of the Clan-na-Gael," Gaelic-American, Mar. 21, 1925. 
Parnellites. For example, Doctor Thomas O'Reilly of St. Louis, a member of the National League Executive Committee, became a prominent member of the Irish National Federation. But several Trianglers stayed neutral. President Fitzgerald and the Irish National League Executive Committee refused to commit their organization to either side, despite the fact that Parnell's envoy, James J. O'Kelly, had personally pleaded with them to endorse Parnell. League officials remembered all too well that a united Irish Parliamentary Party had turned its back on them in 1890, when it directed local American branches to by-pass the central organization and forward their money directly to Dublin. 67 John Sutton, the League Secretary, aptly summed up his colleagues' sentiments: "By Parnell in power and Parnell out of power and by members of McCarthy's following, whether united or disunited, the treatment accorded to the Irish National League has been cowardly, discourteous, and, I may say, treacherous. " 68

Though disgusted with the two rival factions in Ireland, the League Executive Council offered to serve as an arbitrator in settling the dispute. Parnell was receptive to the idea, but his opponents were not. Similarly, Devoy proposed a compromise settlement to John Dillon, one

67 Michael Breslin to Devoy, Jan. 8, 1891, Devoy's Post Bag, Vol. II, p. 317, Irish-American, April 4, 18, 25, May 30, July 25, Aug. 29, 1891; Chicago Citizen, Dec. 6, 13 , 20. 27, 1890, Devoy, "Story of the Clan-na-Gael," GaelicAmerican. Mar. 21, 1925. ${ }^{68}$ Irish-American, Sept. 19, 1891. 
of the leading anti-Parnellites, but was also turned down. Neither the National League nor the Devoyites carried much weight in Ireland, since they were unable to speak for a unified Irish-America. 69

The final convention of the Irish National League of America met in Chicago on October 1, 1891, only a few days before Parnell died. It was a sparsely attended gathering, compared to the Leagye's first convention back in 1883. Only about 400 delegates attended, and the majority of these were Trianglers from around the Chicago area. By this time many Devoyites and conservatives had arifted out of the League. Disillusion with both Irish factions was evident throughout the proceedings. The constitution was changed so that the League no longer had any official connection with the Irish Parliamentary Party. Although some delegates supported a resolution backing the anti-Parnellites, the convention refused by an overwhelming vote to commit itself to either section of the Irish Party. Michael Gannon of Omaha was elected President. The office was meaningless, however, since the League soon passed out of existence altogether. The dream of a united, powerful IrishAmerica had come to an end. 70

If the Cronin murder had helped to wreck the Clan-

${ }^{69}$ Irish-American, Aug. 29, 1891; John Dillon to Devoy, Aug. 6, Sept. 25, 1891; Devoy to Dilion, Aug. 30 , 1891. Devoy's Post Bag, Vol. II, pp. 319-28, Brown, "IrishAmerican Nationalism, 1848-1890," p. 345.

70Irish-American, Sept. 19, oct. 10, 31, 1891. 
na-Gael and the Irish National League of America, it did little in the long run to undermine the political power of the Sullivanites in Chicago. As Finley Peter Dunne's columns in the Evening Journal clearly indicate, the Clan-naGael of the 1890's was still a most productive labor exchange for many Irish-Americans. Indeed, Clansmen like Finerty, Smyth, Buckley, and a host of others continued to hold important political positions during the decade following the Cronin murder. So influential were the Sullivanites that some of the policemen dismissed for their Clan-naGael connections in 1889 were re-instated to the force when Hempstead Washburne became Mayor with Clan support in 1891. 71 Sullivan, it is true, was forced to stay in the background for a few years after the murder; he did not make a public appearance at an Irish rally until March, 1895. Nonetheless, he still remained a powerful force in Chicago politics. In 1895, for example, Devoy bitterly lamented the fact that Sullivan's influence in local politics was still as strong as ever. 72

71 Chicago Evening Journal, Nov. 10, 1893; F. P. Dunne, Mr. Dooley: In the Hearts of His Countrymen (Boston: Small, Maynard and Co., 1899), pp. 42-43. For the political positions held by Chicago Clansmen during the $1890^{\circ} \mathrm{s}$ see the biographical sketches in M. F. Fanning (ed.), The New Movement Convention Which Gave Birth to the Irish National Alliance (Chicago: By the Author, 1896); Charles Ffrench (ed.), A Biographical History of the American Irish in Chicago (Chicago: American Biographical Publishing Co., 1897). For the Clan and the Washburne administration see Chicago Tribune, Feb. 1, 1894.

72 Diary of John Devoy, Devoy Papers, MSS 9820, National Library of Ireland: Chicago Inter Ocean, Mar. 5, 1895; 
Sullivan's fortunes began to wane around the turn of the century. On December 22, 1901 he was convicted of and fined $\$ 2,000$ for helping a jury briber to jump bail. In 1903, however, the Illinois Appelate Court granted him a new trial; the case was later thrown out of court on a technicality. In 1904, the Chicago Bar Association tried to disbar Sullivan but was over-ruled by the Illinois Supreme Court. Though Sullivan, as usual, had outmaneuvered his antagonists, these episodes severely hurt his law practice. This, coupled with his wife's death in 1903, forced him into semi-retirement during the remaining decade of his life. Though no longer active in Irish nationalist affairs, he was still highly respected in Irish Chicago; he was, for instance, a prominent member of the elite Irish Fellowship Club. On August 19, 1913, he developed pneumonia. Father Dorney, his lifelong friend, rushed to his bedside to give him the last rites. In contrast to his stormy life, he died peacefully on August 21. He was buried in Detroit, the city where he had begun his career as an Irish nationalist almost a half century before. 73

Chicago Tribune, Mar. 5, 1895. See also C. H. Harrison, Growing Up ifith Chicago (Chicago: Ralph Fletcher Seymour, 1944), pp. 283-84; C. H. Harrison, Stormy Years: The Autobiography of Carter H. Harrison (Indianapolis: BobbsMerrill Co., 1935), pp. 106-107; $W$. F. Cooling, The Chicago Democracy: A History of Recent municipal Politics (Chicago: Platform Publishing Co., 1899), pp. 20-43.

73"The Case of Dr. Cronin," pp. 349-63; Line of March to the Irish Fellowship Club Banquet, Mar. 17, 1910, Roger Faherty Papers, Chicago Historical Society; Chicago Tribune, Aug. 22, 23, 1913. 
CHAPTER VII

CONCLUSION

Irish-American nationalism in Chicago was the product of a self-conscious immigrant community, : alienated from the dominant Protestant American society by its Catholicism, low economic status, and anti-Irish prejudice. Though it sprang from emotional ties with Ireland and the memories of British oppression. Irish nationalist sentiment was indeed an American phenomenon. The struggle of Irish nationalists for an independent Ireland was part and parcel of their quest for respectability in the United States. Involvement in Irish nationalist activities also eased the identity crisis of many American-reared Irishmen by giving them the opportunity to prove their love and loyalty to the land of their fathers. Similarly, by providing members with the chance to associate with fellow Irishmen, societies like the Clan-na-Gael assuaged the loneliness of many an immigrant, thereby serving a vital social function. Such organizations also supplied ambitious Irish-Americans with opportunities for personal advancement, particularly in the bizarre world of machine politics.

It is true, of course, that the Chicago environment did not play a crucial part in the formation of some of the city's leading Irish nationalists. Clansmen like Sullivan, Finerty, and Hynes were champions of Irish independence before ever arriving in Chicago. But even for individuals 
like these Chicago played an important role, since the conditions there helped to sustain and intensify Irish republican sentiments developed in other and more distant places. Though Chicago's Clansmen shared many of the same aspirations as their cousins in other American cities, the Clan-na-Gael in Chicago had certain distinctive features. The most notable of these involved its relations with the other two chief immigrant institutions, the urban political machine and the Catholic Church.

In Chicago the Clan-na-Gael, excluding the minor Croninite faction, was deeply embroiled in machine politics. Though the Clan seems to have followed a similar pattern in some other areas, it is noteworthy that in some of the large eastern cities there was undisguised hostility between the Clan and Irish politicians. For example, in New York the leaders of the Clan tended to be first generation IrishAmericans who were determined to keep their sacred cause separate from the dirty games of boss politics. By contrast, many prominent Clansmen in Chicago were Americanreared Irishmen, deeply in touch with the grim realities of American urban life. Since some of them had been involved in politics before coming to Chicago, they used their clanna-Gael connections as a means of launching their political careers in their newly adopted city. And since Chicago lacked a powerful centralized machine like Tammany Hall, small cohesive groups like the Clan-na-Gael had a splendid opportunity to act as mini-machines, supporting various 
political cliques in return for a slice of the victory pie. Unlike New York, Boston, and other Eastern cities, the Clan-na-Gael in Chicago also maintained friendly relations with the Catholic Church. Indeed, several Chicago priests, most notably Father Dorney, were themselves members of the Clan. This spirit of good will was in a large measure attributable to the liberal attitude of Archbishop Feehan. Having had the benefit of a relatively liberal education and having spent several years in areas like Nashville, where Irish Catholics were less "ghettoized" and more in touch with American customs and ideas, Feehan tended to be rather open-minded about the Clan-na-Gael and other societies not in strict conformity with the traditional teaching of the Church. Eastern prelates like Corrigan came from more conservative educational backgrounds and lived in cities where there was a greater polarization between the Irish Catholic and American Protestant communities. Consequently, they were more inward-looking and less tolerant of groups that deviated from rigid Catholic norms. of course, even if Chicago had a conservative bishop, he would have had a difficult task in trying to sever the close ties between the priests and the Clan. Since Chicago had a tradition of weak bishops, priests were accustomed to ruling their parishes like private fiefs, paying scant attention to the bishop. For example, in the late 1890's when Feehan tried to nominate Bishop Vuldoon as auxiliary bishop, a group of twenty-three priests led by Father Hugh Smyth, the 
brash pastor of St. Mary's Church in Evanston, sent a delegation to the Apostolic Delegate in Washington to propose their own candidate in opposition to Muldoon. 1

The Church's friendly attitude toward the Clan-naGael largely accounts for the absence of any strong conservative Irish nationalist movement in Chicago. But it fails to tell the whole story, for in the East much of the conservative strength lay among the wealthy Irish. By contrast, many of Chicago's well-to-do Irishmen, including John M. Smyth, Daniel Corkery and Patrick McGarry, were members of the Clan-na-Gael. Perhaps the reason for this is that in Chicago the semi-frontier conditions, though quickly fading, helped to blur the lines between the lace-curtain and poor Irish, and thus wealthy Irish-Americans were not as reluctant to identify themselves with a movement comprised primarily of lower-class Irishmen.

The Irish community in Chicago was, therefore, more cohesive and united than those in some of the large Eastern cities. The major division in Irish Chicago (between the Sullivanites and the Croninites) occurred within the Clanna-Gael, not between priest, politician, and nationalist as in the East. And it must be remembered that the croninites represented only a minor faction of the Chicago Irish. Chicago's Irish nationalists had more than a local impact, for during the decade of Parnell's ascendancy they

1 "The Untold Story of Catholic Chicago," Dec., 1966, Special supplement, Chicago Daily News. 
played a major role in Irish-American affairs. When Sullivan took over the reins of the Clan-na-Gael in the summer of 1881 , he reversed the Clan's ambivalent policy toward the American Iand League and began to make a concerted effort to capture the constitutional Irish-American movement, a goal he achieved with the creation of the Irish National League of America in April, 1883. Though Sullivan and his wing of the Clan-na-Gael were more than willing to support Parnell's parliamentary campaign for Home Rule, they remained firmly dedicated to the idea of establishing an Irish republic by force of arms. The relationship between the Sullivanites and Parnell was basically one of expedience. Since the I. R. B. was completely moribund, Sullivan had no other organization to turn to in Ireland but the Irish Parliamentary Party. Had the I. R. B. been as well organized as in 1916 , the alliance between Parnell and the Clan in the period following Kilmainham would, no doubt, have been far more stormy. Chicago's Clansmen, of course, admired Parnell's accomplishments but as heirs of Tone and Emmet they never held him in as high esteem as the conservatives in the East.

It is easy to view Sullivan and his cronies as opportunists using the Irish cause to further their own selfish ambitions. Devoy and his friends were fond of pointing out that political entanglements had wrecked the Irish movement in the United States. While this is largely true, it must be emphasized that if American politics hurt the Irish cause, it also did much to help it. By tying the rather 
elusive and idealistic aims of Irish nationalism to the concrete needs of American urban life, Clan-na-Gael politicians in Chicago made their organization a more viable force than it otherwise might have been. Bread and butter politics did much to keep interest in the Clan alive when the prospects for an Irish republic seemed far off in the distant future. It is noteworthy that the Irish National League, which provided few practical benefits for Irish-Americans, survived less than a decade, while the Clan in Chicago was still a thriving institution at the turn of the century.

Though Sullivan and his followers did much to destroy the Irish National League and the national organization of the Clan-na-Gael, Devoy and his allies, by their unwillingness to forget past differences and bury the hatchet after the Union Convention in June, 1888, must also share a large part of the blame for the difficulties in IrishAmerica. Indeed, the list of Irish nationalists Devoy alienated in his lifetime would be enough to make any orangeman turn green with envy. While Devoy and future intransigents like De Valera devoted their lives to Ireland, one wonders at times if she would have accomplished more without them. 
BIBLIOGRAPHY

Primary Sources

Manuscript Collections

Chicago Historical Society

James B. Campbell Papers

Frank Conlan Papers

Patrick Henry Cronin Collection

Elizabeth P. Dutton Collection

Roger Faherty Papers

Items Relative to the John F. Finerty Memorial Statue

Michael McDermott, Recollections and Memories. Photostat copy of original in the Library of Congress.

Harriet A. Rosa Collection

St. Columbkille Parish Minutes, December, 1858.

Newberry Iibrary

Lars P. Nelson. Statistics Showing by Divisions, Wards, and Voting Precincts the Original Nationality of the Voters of Chicago. Handwritten copy, 1887.

Archdiocesan Archives of Chicago

Archbishop James E. Quigley Papers

Office of the Coroner of Cook County, Illinois

Coroner's Inquest Record, May-November, 1889.

Illinois State Historical Society

Richard J. Oglesby Papers 
University of Notre Dame Archives

Archdiocesan Archives of New York, Photostat Copies

Henry F. Brownson Papers

Chicago Papers

Austin Ford Papers

Daniel E. Hudson Papers

James A. McMaster Papers

William J. Onahan Papers

New York Public Library

Jeremiah $0^{\prime}$ Conovan Rossa Papers in the Margaret McKim Maloney Collection

National Library of Ireland

John Devoy Papers

Timothy Harrington Papers

John O'Leary Papers

Newspapers

Chicago

Daily News, April 9, 1909; Dec., 1966.

Herald, May - Dec., 1889.

Inter Ocean, Sept., 1888; May - Dec., 1889; Mar. 1894; Aug. 22, 1913.

Journal, Nov., 1893.

Journal of the Town of Lake, Sept. 14, 1939.

Times, Dec. 1-3, 1881; Sept. - Nov., 1882; June - Nov., 1884; June - Nov., 1888 .

Times-Herald, Oct. 20, 1895. 
Tribune, April 19, 1874; 1880-1889; Nov., 1893-Mar., 1894; Mar. 5, 1895; Aug. 22, 1913.

Irish-American

Chicago Citizen, 1883-1891

Gaelic-American, 1906, 1923-25.

Irish-American, 1880-1891.

Irish Nation, 1881-1883.

Irish World, 1880-1891.

Newspaper Scrapbooks

The Cronin Case Scrapbook, Library of the Chicago Historical Society

Carter H. Harrison II Scrapbooks, Newberry Library.

Scrapbooks of American Public Opinion Editorials from the Leading Papers of America on the Home Rule Bill for Ireland, Presented to W. E. Gladstone and Charles S. Parnell from the Irish National League of America, Harrington Papers, National Iibrary of Ireland.

Contemporary Periodical Articles

Babcock, J. P. "The Irish Conquest of Our Cities," The Forum, Vol. XVII (1894), pp. 186-195.

Davitt, Michael. "The Report of the Parnell Commission," Nineteenth Century, Mar. 1890, pp. 357-83.

McGlynn, Edward. "The New Know-Nothingism and the 01d," North American Review, Vol. CXIV (1887-88), pp. 192-205.

Onahan, William J. "Irish Settlement in Illinois," Catholic World, Vol. XXXIII (1881), pp. 157-62.

Sullivan, Alexander. "The American Republic and the Irish National League of America," American Catholic Quarterly Review, Vol. IX (1884), pp. 35-44. 
Government Publications

City of Chicago. Annual Messages of the Mayors, 1887-95.

City of Chicago, Board of Education. School Census of the City of Chicago, Taken May, 1884. Total Population of the City. Over 21 Years and Under 21 Years of Age. By Ward and Division of the City. Chicago, 1884 .

City of Chicago, City Council. Proceedings, 1879/80$1889 / 90$.

City of Chicago, Police Department. Report of the General Superintendent of Police of the City of Chicago to the City Council, 1885,1890 .

Dillingham, William $P_{\text {. Reports of the Immigration }}$ Commission. 41 Vols. Washington: Government Printing Office, 1911.

Great Britain. Report of the Special Commission, 1888. [C 5891$]$ H. C. 1890, Vol. XXVII, Pp. 477-640.

Great Britain. Special Commission Act, 1888. Reprint of the Shorthand Notes of the Speeches, Proceedings and Evidence Taken Before the Commissioners. 12 Vols. London: H. M. S. 0., 1890 .

Illinois. Reports of Cases at Law and in Chancery, Argued and Determined in the Supreme court of Illinois. Vol. 144. Springfield, 1893.

U. S. Biographical Directory of the American Congress, $1774-$ 1949. Washington: Government Printing Office, 1950 .

U. S. Bureau of the Census. Compendium of the Eleventh Census, 1890. 3 Vols.

Historical Statistics of the United States. Washington: Government Printing Office, 1961.

Eleventh Census, 1890. Parts I, II.

U. S. Bureau of Labor. The Slums of Baltimore, Chicago, New York, and Philadelphia. Edited by Carroll D. Wright. Washington: Government Printing office, 1894 . 
Reports, Pamphlets, Guides and Almanacs

Barton, Elmer E. A Business Tour of Chicago. Chicago: By the Author, 1887 .

Blanchard, Rufus. BIanchard's Guide to Chicago, Showing Street Numbers and How to Find Them. Chicago: Blanchard, 1901.

Map of the Environs of Chicago. Chicago: Blanchard, 1888.

The Bon-Ton Directory Giving the Names in Alphabetical Order, Addresses and Hours of Reception of the Most Prominent and Fashionable ladies Residing in Chicago and Its Suburos. Chicago: Blakely, Brown, and Marsh, 1879-80.

Chicago Bureau of Associated Charities. Stock Yards District. Chicago, 1898.

Chicago City Missionary Society. Annual Report, 1882-84, 1888, 1890. Chicago, 1882-90.

Chicago and Cook County Official Republican Directory and Sketch Book, 1900. Chicago: R. P. O'Grady, 1900.

Chicago Daily News Almanac, 1885-1893.

Chicago Erring Woman's Refuge for Reform. Annual Report. 1883-94. Chicago, 1883-94.

Chicago Home for the Friendless. Annual Report, 1881-90. Chicago, 1881-90.

Chicago Relief and Aid Society. Annual Report, 1886-88. Chicago, 1886-88.

Citizens' Association of Chicago. Address and Reports, 1882-90. Chicago, 1882-90.

Democratic Party of Cook County, Illinois. Blue Book of Cook Co. Denocracy, 1902. Chicago: P. F. Pettibone \& Co., 1902.

The Elite Directory and Club List of Chicago, 1884/85. Chicago: The Elite Directory Co., 1884.

Fanning, M. $\vec{F}$. (ed.). The New Movement Convention Which Gave Birth to the Irish National Alliance. Chicago: By the Author, 1896. 
Flinn, John J. Chicago, The Marvelous City of the West. A History, an Encyclopedia, and a Guide, Chicago: The Standard Guide Co., 1892.

Holy Name Cathedral, Chicago. Miscellaneous Pamphlets. Hull-House Maps and Papers. New York: T. Y. Crowell and Co., 1895.

Hunter, Robert. Tenement Conditions in Chicago. Chicago: City Homes Association, 1901.

Irish Fellowship Club of Chicago. Irish Fellowship Club of Chicago: Its History and objectives, 1902-1953. Chicago: Irish Fellowship Club of Chicago, 1953.

McGovern, James J. (ed.). Souvenir of the Silver Jubilee in the Episcopacy of His Grace, the Most Rev. Patrick Augustine Feehan, Archbishop of Chicago. Chicago, n. p., 1891.

Marquis, Albert N. Marquis' Handbook of Chicago, A Complete History, Reference Book, and Guide to the City. Chicago: A. N. Marquis \& Co., 1885.

Moran, George E. Moran's Dictionary of Chicago and Its Vicnity. Chicago: G. E. Moran, 1892.

Morris, Frank M. Morris' Dictionary of Chicaso and Vicinity. Chicago: F. M. Morris, 1891.

Official Proceedings of the Democratic National Convention, 1884. New York: Douglas Taylor's Democratic Printing House, 1884.

Official Proceedings of the National Democratic Convention, 1888. St. Louis: Woodward and Tiernan Printing Co., 1888 .

Official Proceedings of the Republican National Convention, 1884. Minneapolis: Charles W. Johnson, 1903.

Official Proceedings of the Republican National Convention, 1888. Minneapolis: Charles W. Johnson, 1903.

Parnellism and Crime: The Special Commission, Reprinted from the Times. 35 Parts. London: G. E. Wright, 1888-90.

Piper, Alexander R. Report of An Investigation of the Discipline and Administration of the Police Department of the City of Chicago. Chicago: City Club of Chicago, 1904. 
Rand McNally and Company's Bird's-Eye Views and Guide to Chicago Business and Residence Localities. Chicago: Rand licNally \& Co., 1893.

Rand McNally. Map Showing the Boulevards and Park System and Twelve Miles of Lake Frontage of the City of Chicago. Chicago: Rand MeNally \& Co., 1888.

Stine, Edwin. What Everybody Wants to Know About Chicago. Chicago: E. Stine, 1890.

The Third Annual Convention of the Irish National Land League of America and the First Convention of the Irish National League of America. Buffalo: Union Times Print, 1883.

West Side Elite Directory and Calling List. Chicago: Cushing, Thomas, and Co., 1884.

West Side Society Directory, Chicago, 1890. Chicago: Chicago Ladies Home Journal Co., 1890.

Who's who in Chicago and Illinois, 1905, 1911. Chicago: A. N. Marquis, 1905, 1911.

Autobiographies, Memoirs, Published Letters, and Novels

Addams, Jane. Twenty Years at Hull House. New York: New American Library, n.d.

Anderson, Robert. Sidelights on the Home Rule Movement. London: J. Murray, 1906.

Beach, Thomas M. Twenty- Tive Years in the Secret Service. London: Heinemann, 1892.

Bowen, Louise Hadduck. Growing Up with a City. New York: The Macmillan Co., 1926.

Clark, Herma N. The Elegant Eighties When Chicago Was Young. Chicaso: A. C. IfeClurg and Co., 1941.

Cleaver, Charles. Early-Chicago Reminiscences. Chicago: Fergus Printing Co., 1882 .

History of Chicago from 1833 to 1892. Chicago: By the Author, 1892 .

Cook, Frederick F. Bysone Days in Chicago: Recollections of the "Garden City" of the Sixties. Chicago: A. C. MCCIurg and Co., 1910 . 
Coyne, Frederick E. In Reminiscence, Highlight of Men and Events in the Life of Chicago. Chicago: By the Author, 1941.

Croarkin, Francis E. Ninety Years: The Autobiography of Francis E. Croarkin. Chicago: By the Author, 1952.

Cullom, Shelby M. Fifty Years of Public Service. Chicago: A. C. McClurg \& Co., I9II.

Davitt, Michael. The Fall of Feudalism in Ireland or The Story of the Land League Revolution. New York: Harper, 1904.

The 'Times'-Parnell Commission: Speech Delivered by Michael Davitt in Defence of the Land League. London: Kegan Paul, Trench, Trubner and Co., 1890.

Denieffe, Joseph. A Personal Narrative of the Irish Republican Brotherhood. New York: Gael, 1906.

Devoy, John. Land of Eire. The Irish Land League; Its Origin, Progress and Consequence. New York: Patterson and Neilson, 1882 .

Recollections of a Rebel. New York: Charles Young, 1929.

Dodge, Chester C. Reminiscences of a School Master. Chicago: R. F. Seymour, 1941 .

Dreiser, Theodore. Sister Carrie. New York: New American Library, $196 \overline{I .}$

The Titan. New York: New American Library, 1965.

Dunne, Finley Peter. Mr. Dooley: In the Hearts of His Countrymen. Boston: Small, Maynard and Co., 1899.

Mr. Dooley: In Peace and War. Boston: Small, Maynard and Co., 1899.

Mr. Dooley Remembers: The Informal Miemoirs of Finley Peter Dunne. Edited by Philip Dunne. Boston: Iittle, Brown, and Co., Atlantic Monthly Press Book, 1963.

Farrell, James T. Studs Lonjgan: Youno Lonigan, The Young Manhood of Studs Loniean, Judrement Day. New York: New American Library, 1965. 
Finerty, John F, The People's History of Ireland. 2 Vols. New York: The Co-operative Publication Society, 1904.

War-Path and Bivouac or the Conquest of the Sioux. Norman: University of Oklahoma Press, 1961.

Gale, Edwin 0. Reminiscences of Early Chicago and Vicinity. Chicago: Fleming H. Revell Co., 1902.

Harrison, Benjamin. Speeches of Benjamin Harrison, Twentythird President of the United States: A Complete Collection of His Public Addresses from February, 1888 to February, 1892. Edited by Charles Hedges. New York: United States Book Co., 1892.

Harrison, Carter H. Growing Up with Chicago. Chicago: Ralph Fletcher Seymour, 1944.

Stormy Years: The Autobiography of Carter $H$. Harrison, Five Times Nayor of Chicago. Indianapolis: Bobbs-Merrill Co., 1935.

Healy, T. M. Letters and Leaders of My Day. 2 Vols. Iondon: Butterworth, 1928.

Hermann, Charles H. Recollections of Life and Doings In Chicago from the Haymarket Riot to the End of World War I. Chicago: Normandie House, 1945.

James, Henry. The Work of the Irish Leagues: The Speech of Sir H. James Replying in the Parnell Commission Inquiry. London: Published for the Iiberal Unionist Association by Cassell and Co., 1890.

Kirkland, Caroline (ed.). Chicago Yesterdays: A Sheaf of Reminiscences. Chicago: Daughaday and Co., 1919.

Knaplund, Paul and Clews, Carolyn M. (ed.). "Private Letters from the British Embassy in Washington to the Foreign Secretary Lord Granville, 1880-1885," Annual Report of the American Historical Association, 1941 , pp. 73-189. Washington: Government Printing Office, 1941 .

Maher, James (ed.). The Valley Near Slievenamon: A Kickham Anthology. Mullinahone, Co. Tipperary: By the Author, 1942.

McConnell, Edward. Reminiscence of An Emigrant from Dublin to America. n. p., 1860 . 
McIlvaine, Mabel (ed.). Reminiscences of Early Chicago. Chicago: R. R. Donnelley and Sons, 1912.

Reminiscences of Chicago during the Civil War. Chicagos R. R. Donnelley and Sons, 1914.

Reminiscences of Chicago during the Forties and Fifties. Chicago: R. R. Donnelley and Sons, 1913. Reminiscences of Chicago during the Great Fire. Chicago: R. R. Donnelley and Sons, 1915.

McKenna, John J. Stories by the Original "Jawn" McKenna from "Archy Road" of the Sun Worshipers Club of McKinley Park in their Political Tales and Reminiscences. Chicago: By the Author, 1918.

O'Brien, William. Recollection. London: Macmillan \& Co., 1905.

Evening Memories. Dublin: Maunsel and Co., 1920.

O'Brien, William and Ryan, Desmond (eds.). Devoy's Post Bag, 1871-1928. 2 Vols. Dublin: Fallon, 1948-53.

$0^{\circ}$ Connor, T. P. Memoirs of an Old Parliamentarian. 2 Vols. Iondon: Benn, 1929.

O'Donnell, F. H. A History of the Irish Parliamentary Party. 2 Vols. London: Longmans, Green, and Co., 1910 .

o'Leary, John. Recollections of Fenians and Fenianism. 2 Vols. London: Downey and Co., 1896.

Powderly, T. V. Thirty Years of Labor, 1859 to 1889.

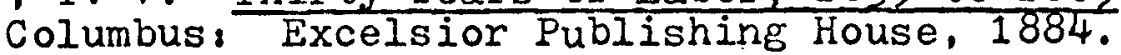

Rossa, Jeremiah O'Donovan. Rossa Recollections. Mariner's Harbor, New York: By the Author, 1898.

Russell, Charles. Diary of a Visit to the United States of America. Edited by Charles G. Herbermann. New

York: The United States Catholic Historical Society, 1910.

The Parnell Commission: The Opening Speech for the Defense. London: Macmillan and Co., 1889.

Ryan, M. F. Fenian Memories. Dublin: M. H. Gill and Sons, 1946.

Sinclair, Upton. The Jungle. New York: Doubleday, Page, 1906. 
Stone, Melville E. Fifty Years a Journalist. New York: Doubleday, Page, 1923.

Sullivan, William L. (ed.). Dunne: Judge, Mayor, Governor. Chicago: The Windermere Press, 1916.

Tynan, Patrick J. P. The History of the Irish National Invincibles and Their Times. New York: Irish National Invincible Publishing Co., 1894.

Wilkie, Franc B. Personal Reminiscences of Thirty-Five Years of Journalism. Chicago: F. J. Schulte and Co., 1891 .

Abbot, Willis J. Carter Henry Harrison: A Memoir. New York: Dodd, Mead, and Co., 1895.

Abbott, Edith. The Tenements of Chicago, 1908-1935. Chicago: University of Chicago Press, 1936.

Adams, William F. Ireland and Irish Emigration to the New World from 1815 to the Famine. New York: Russell and Russell, 1967.

Ahern, M. L. The Great Revolution. A History of the Rise and Progress of the People's Party in the City of Chicago and County of Cook. Chicago: Lakeside Publishing and Printing Co., 1874.

Akenson, Donald H. The Irish Education Experiment: The National System of Education in the Nineteenth Century. Toronto: University of Toronto Press, 1969.

Allswang, John M. A House for All Peoples: Ethnic Politics in Chicago, 1890-1936. Lexington: University of Kentucky Press, 1971.

Andreas, Alfred $\mathrm{T}$. History of Chicago. 3 Vols. Chicago: A. T. Andreas Co., $1884-86$.

Arnold, Isaac N. William B. Ogden and Early Days in Chicago. Chicago: Fergus Printing Co., 1882.

Athearn, R. G. Thomas Francis Meagher: An Irish Revolutionary in America. Boulder: University of Colorado Press, 1949. 
Bagenal, Philip H. The American-Irish and The ir Influence on Irish Politics. London: Kegan Paul, Trench, 1882 .

Barker, Charles A. Henry George. New York: Oxford University Press, 1955.

Barnard, Harry. "Eagle Forgotten": The Life of John Peter Altgeld. New York: Duell, Sloan, and Pearce, 1938.

Beckett, J. C. The Making of Modern Ireland, 1603-1923. New York: Alfred A. Knopf, 1966.

Beckner, Earl R. A History of Labor Legislation in Illinois. Chicago: University of Chicago Press, 1929.

Beijbom, Ulf. Swedes in Chicago: A Demographic and Social Study of the 1840-1880 Immigration. Chicago: Chicago Historical Society Press, 1971.

The Bench and Bar of Chicago: Biographical Sketches. Chicago: American Biographical Publishing Co.. 1883.

Bennett, F. O. Politics and Politicians in Chicago, Cook County and Illinois. Memorial Volume, $1787-1887$. Chicago: The Blakely Printing Co., 1886.

Berthoff, R. T. British Immigrants to Industrial America, 1790-1950. Cambridge: Harvard University Press, 1953.

Billington, Ray Allen. The Protestant Crusade, 1800-1860: A Study of the Oririns of American Nativism. New York: Rinehart and Co., 1952.

Biographical Sketches of the Leading Men of Chicago. Chicago: Wilson, 1876.

Bland, Joan. Hibernian Crusade. Washington: Catholic University of America Press, 1951.

Blunt, $1 . S$. The Land War in Ireland. London: Herbert and Daniel, 1912 .

Bolton, G. C. The Passing of the Irish Act of Union. Iondon: Oxford University Press, 1966.

Bourke, Narcus. John O'I,eary: A Study in Irish Separation. Tralee, Co. Korry: Anvil Books, 1967.

Bowers, David F. (ed.). Foreign Influences in American Iife. Princeton: Princeton University Press, 1944. 
Brent, Edgar W. Martin B. Madden: Public Servant. Chicago: n. p., 1901 .

Broderick, John F. The Holy See and the Irish Movement for the Repeal of the Union with England, 1829-1847. Rome: Universitatis Gregorianae, 1951.

Broehl, Wayne. The Molly Maguires. Cambridge: Harvard University Press, 1964.

Brown, James. The History of Public Assistance in Chicago, 1833 to 1893 . Chicago: University of Chicago Press, 1941 .

Brown, Thomas N. Irish-American Nationalism, 1870-1890. Philadelphia: Lippincott, 1966.

Browne, H. J. The Catholic Church and the Knights of Labor. Washington: Catholic University of America Press, 1949.

Brownson, Howard $G$. The History of the Illinois Central Railroad to 1870. Urbana: University of IIlinois Press, 1915 .

Buder, Stanley. Pullman: An Experiment in Industrial order and Community Planninge 1.880-1930. New York: Oxford University Press, 1967.

Bushnell, Charles J. The Social Problem at the Chicago Stock Yards. Chicago: University of Chicago Press, 1902 .

Callow, Alexander B. The Tweed Ring. New York: Oxford University Press, 1966.

Cashman, D. B. The Life of Michael Davitt. Boston: Murphy and McCarthy, I881.

Chicago Municipal Reference Library. Centennial List of Mayors, City Clerks, City Attorneys, City Preasurers and Aldermen, Elected by the People of the City of Chicaso from. . Warch 4, 1837 to March 4, 1937. Compiled by rederick Rex. Chicago: Chicago hínicipal Reference Iibrary, 1937.

Chicago Times Company. Chicago and Its Resources Twenty Years After, 1871-1891. Chicago: Chicago T'imes Co., 1892 .

Cole, Arthur C. The Era of the Civil. War, 1848-70. Vol. III in the Centennial History of Illinois. Springfield: Illinois Centennial Commission, 1919. 
Coleman, James $w$. The Molly Maguire Riots: Industrial. Conflict in the Pennsylvania Coal Redion. Richmond, Virginia: Garrett and Massie, 1936.

Collison Black, R. D. Economic Thought and the Irish Question, 1817-1870. Cambridge: Cambridge University Press, 1960 .

Commons, John R. et. al. The History of Labour in the United States. 4 Vols. New York: The viacmillan Co., 1918-35.

Connell, K. H. The Population of Ireland, 1750-1845. Iondon: Oxford University Press, 1950.

Cooling, Walter F. The Chicago Democracy. A History of Recent Munjcipal Politics. Chicago: Platiorm Publishing Co., 1899.

Corfe, Tom. The Phoenix Park Murders: Conflict, Compromise and Trasedy in Ireland, 1879-1882. London: Hodder and Stoughton, 1968.

Cross, Robert D. (ed.). The Church and the City, 18651910. Indianapolis: Bobbs-Werrill, 1967.

The Emergence of Ijberal Catholicism in America. Cambridge: Harvard University Press, 1958.

Currey, Josiah S. Chicaro: Its History and Its Builders: A Century of Mlarvelous Growth. Chicago: S. J. Clarke Publishing Co., 1912.

Curran, M. P. The Iife of Patrick A. Collins. Norwood, Massachusetts: The Norwood Press, 1906.

Curtis, I. P., Jr. Anglo-Saxons and Celts: A Study of Anti-Irish Prejudice in Victorian England. Bridgeport, Conn.: Conference on British Studjes, 1968.

Coercion and Conciliation in Ireland, 1880-1892.

Princeton: Princeton University Press, 1963.

D'Arcy, william. The Fenian Movement in the United States, 1858-1886. Washington: Catholic University of America Press, 1947.

David, Henry, The History of the Haymarket Affair. New York: Russell and Russell, 1958.

Dedmon, Emmett. Fabulous Chicago. New York: Random House, 1953. 
Dennis, Charles H. Eugene Field's Creative Years. New York: Doubleday, Page, 1924.

Victor Iawson: His Time and His Work. Chicago: University of Chicago Press, 1935.

Desmond, H. J. The A. P. A. Movement. Washington: New Century Press, 1912.

Destler, Chester M. American Radicalism, 1865-1900. Chicago: Quadrangle Books, 1966.

Donohoe, J. M. The Irish Catholic Benevolent Union. Washington: Catholic University of America Press, 1953.

Duffy, C. G. Young Ireland: A Fragment of Irish History. London: T. Fisher Unwin, 1896.

Duncan, Hugh D. The Rise of Chicago as a Literary Center from 1885 to 1920: A Sociological Essay in American Culture. Totowa, New Jersey: The Bedminster Press, 1964.

Dunne, Edward F. Illinois, the Heart of the Nation. 5 Vols. Chicago: The Lewis Publishing Co., 1933.

Edwards, R. D. and Williams, T. D. (eds.). The Great Famine: Studies in Irish History, 1845-1852. DubIin: Browne and Nolan, 1956.

Ellis, Elmer. Nr. Dooley's Amerjca: A Life of Finley Peter Dunne. New York: Alfred A. Knopf, 1941.

ElJis, John T. American Catholicism. Chicago: University of Chicago Press, 1956.

The Iife of James Cardinal Gibbons, 2 Vols. Milwaukee: Bruce Publishing Co., 1952.

Erickson, Charlotte. American Industry and European Immigration: 1860-1885. Cambridge: Harvard University Press, 1957.

Ernst, Robert. Immigrant Iife in New York City, 1825-1863. Port Washington, New York: Ira J. Friedman, 1965.

Evangeline, Thomas $M$. Nativism in the old Northwest, 18501860. Washington: Catholic University of America Press, 1936.

Faulkner, Harold U. Politics, Reform and Expansion, 18901900. New York: Harper and kow, 1959. 
Ffrench, Charles (ed.). A Biographical History of the American Irish in Chicago. Chicago: American Biographical Publishing Co., 1897.

Flinn, John J. The Hand-Book of Chicago Biography: A Compendium of Useful Biographical Information for Reference and Study. Chicago: Standard Guide Co., 1893.

Flinn, John, History of the Chicago Police: From the Settlement of the Community to the Present Time. Police Book Fund, 1887.

Freeman, Thomas W. Pre-Famine Ireland: A Study in Historical Geography. Manchester: Manchester University Press, 1957.

Garraghan, G. J. The Catholic Church in Chicago. Chicago: Loyola University Press, 1921.

Garraty, John A. The New Commonwealth, 1877-1890. New York: Harper and Row, 1968.

Gates, Paul w. The IIlinois Central Railroad and Its Colonization Work. Cambridge: Harvard University Press, 1934.

Genealogical and Biographical Record of Cook County, Illinois. Chicago: Lake City Publishing Co., 1894.

Gibson, Florence. The Attitudes of the New York Irish toward State and National Affairs, 1848-1892. New York: Columbia University Press, 1951.

Ginger, Ray. Altgeld's America: The Iincoln Ideal Versus Changing Realities. Chicago: Quadrangle Books, 1965.

Glazer, Nathan and Moynihan, Daniel P. Beyond the Melting Pot: The Negroes, Puerto Ricans, Jews, Italians, and Irish of New York City. Cambridge: M. I. T. Press, 1963.

Goodspeed, Weston A, and Healy, Daniel D. History of Cook County, Illinois. 2 Vols. Chicago: Goodspeed Historical Association, 1911.

Gottfried, Alex. Boss Cermak of Chicago: A Study in Political Leadership. Seattle: University of Washington Press, 1962 .

Grant, Bruce. Fight for a City: The Story of the Union Learue CIub of Chicamo and Its imes, 1880-1955. Chicago: Rand, MeNally, 1955. 
Greeley, Andrew $M$. The Catholic Experience: An Interpretation of the History of American Catholicism. Garden City, New York: Doubleday and Co., Image Book Ed., 1969.

That Most Distressful Nation: The Taming of the American Irish. Chicago: Quadrangle Books, 1972 .

Gwynn, Denis. Young Ireland and 1848. Cork: Cork University Press, 1949.

Gwynn, Stephen (ed.). The Letters and Friendships of Sir Cecil Spring Rice. 2 Vols. Boston: Houghton Nifflin Co., 1929.

Hammond, J. I. Gladstone and the Irish Nation. Hamden, Conn.: Shoe String Press, 1964.

Handlin, 0scar. Boston's Immigrants. Revised Edition. New York: Atheneum, 1969.

The Uprooted. Boston: Iittle, Brown, 1951.

Hansen, Marcus. The Atlantic Migration, 1607-1860. New York: Harper and Row, 1961.

The Immigrant in American History, Cambridge: Harvard University Press, 1940.

Henthorne, Sister Mary Evangela. The Irish Catholic Colonization Association of the United States. Champaign, Illinois: The Twin City Printing Co., 1932.

Hernon, Joseph M. Jr. Celts, Catholics, and Copperheads: Ireland Views the American Civil Var. Columbus, Ohio: Ohio State University Press, 1968.

Higham, John. Strangers in the Land: Patterns of American Nativism, 1860-1925. New Brunswick: Rutgers University Press, 1935.

Holy Name Cathedral, Chicago. 100 Years: The History of the Church of the Holy Name; The Chapel that Became a Cathedral and the Story of Catholicism in Chicago. Chicago: Holy Name Cathedral, 1949.

Holy Rosary Parish, Chicago. Holy Rosary Parish, 18821257: 75th Anniversary. n. p., n. d.

Hormer, Thomas I. Fifty Years of Parish History, Church of the Annunciation, 1866-1916. Chicago: n. p., 1916 . 
Hunt, Henry $M$. The Crime of the Century or the Assassination of Dr. Patrick Henry Cronin. Chicago: H. L. and D. H. Kockersperger, 1889.

Hutchinson, Edward P. Immigrants and Their Children, 18501950. New York: Wiley, 1956.

Hurst, Michael. Parnell and Irish Nationalism. Toronto: University of Toronto Press, 1968.

Jackson, J. A. The Irish in Britain. London: Routledge and Kegan Paul, 1963.

Jenkins, Brian. Fenians and Anglo-American Relations During Reconstruction. London and Ithaca: Cornell University Press, 1969.

Jensen, Richard. The Winning of the Midwest: Social and Political Conflict, 1888-1896. Chicago: University of Chicago Press, 1971.

Jeter, Helen R. Trends of Population in the Region of Chicago. Chicago: University of Chicago Press, 1927.

Johnson, Claudius 0 . The Life of Carter H. Harrison I. Chicago: University of Chicago Press, 1928.

Johnson, Stanley C. A History of Emigration from the United Kingdom to North America: 1763-1912. London: G. Routledge and Sons, 1913 .

Jones, Maldyn A. American Immigration. Chicago: University of Chicago Press, 1960.

Kelly, Sister Mary Gilbert. Catholic Immigrant Colonization Projects in the United States, 1815-1860. New York: United States Catholic Historical Society, 1939.

Kinsley, Philip. The Chicago Tribune: Its First Hundred Years. 3 Vols. New York: A. A. Knopf, 1943-46.

Kinzer, Donald I. An Episode in Anti-Catholicism: The American Protective Association. Seattle: University of Washington Press, 1964.

Kirkfleet, Cornelius. The Life of Patrick Aurustine Feehan, Bishop of Nashville, First Archbishop of Chicago, 1829-1902. Chicago: Natre and Co., 1922.

Kirkland, William and Moses, John. History of Chicago. 2 Vols. Chicago: Munsell and Co., 1895. 
Kleppner, Paul J. The Cross of Culture: A Social Analysis of Midwestern Politics, 1850-1900. New York: Free Press, 1970.

La Feber, Walter, The New Empire: An Interpretation of American Exnansion, 1860-1898. Ithaca: Cornell University Press, 1963.

Le Roux, Louis M. Tom Clarke and the Irish Freedom Movement. Dublin: Talbot, 1936.

Levine, Edward M. The Irish and Irish Politicians. Notre Dame: University of Notre Dame Press, 1966.

Lewis, Lloyd and Smith, Henry J. Chicago: The History of Its Reputation. New York: Harcourt, Brace, and Co., 1929.

Iindsey, Almont. The Ptllman Strike: The Story of an Unique Experiment and of a Great Labor Upheaval. Chicago: University of Chicago Press, 1942.

Lynch, Denis T. Grover Cleveland: A Man Four Square. New York: H. Liveright, 1932.

Lyons, F. S. I. The Fall of Parnell, 1890-91. London: Routledge and Kegan Paul, 1960.

Ireland Since the Famine. New York: Charles Scribner's Sons, 1971.

The Irish Parliamentary Party, 1890-1910. London: Faber and Faber, 1951.

John Dillon: A Biography. Chicago: University of Chicago Press, 1968.

McAvoy, Thomas T. and Brown, Thomas N. The United States of America: The Irish Clergyman, The Irish Layman, Vol. VI, No. 2, A History of Irish Catholicism. Dublin: Gill and Vacmillan, 1970.

McCaffrey, Lawrence J. Daniel $0^{\prime}$ Connell and the Repeal Year. Lexington: iniversity of Kentucky Press, 1966.

Irish Federalism in the 1870's: A Study in Conservative Nationalism. Philadelphia: American Philosophical Society, 1962.

The Irish Question, 1800-1922. Lexington: University of Kentucky Press, 1968.

McCarue, James. The Second Rebellion. New York: Dial Press, 1968. 
McClure, J. B. (ed.). Storjes and Sketches of Chicago. Chicago: Rhodes and McClure, 1880.

MacDonald, Fergus. The Catholic Church and the Secret Societies in the United States. New York: United States Catholic iristorical Society, 1946.

McDonald, Sister M. Justille. History of the Irish in Wisconsin in the Nineteenth Century. Washington: Catholic University of America Press, 1954.

McDowell, Robert B. Irish Public Opinion: 1750-1800. London: Faber and Faber, 1943.

Public Opinion and Government Policy in Ireland, 1801-1846. New York: Hillary, 1952.

McEnnis, John T. The Clan-na-Gael and the Murder of Dr. Cronin. Chicago: F.J. Schulte and J.W. Iliff, 1889.

McGee, Thomas D. A History of the Irish Settlers in North America from the Earliest Period to the Census of 1850. Boston: Office of the American Celt, 1851 .

Machin, G. I. T. The Catholic Question in English Politics, 1820-1830. London: Oxford University Press, 1964.

MacIntyre, Angus. The Iiberator: Daniel o'Connel] and the Party, 1830-1847. London: H. Hamilton, 1965.

McKelvey, Blake. The Urbanization of America, 1860-1915. New Brunswick: Rutgers University Press, 1963.

Magnus, Philip. Gladstone. London: John Murray, 1954.

Maguire, John F. The Irish in America. London: Longmans,

Mandelbaum, Seymour J. Boss Tweed's New York. New York: John Wi.ley and Sons, 1965.

Mann, Arthur. Yankee Reformers in the Urban Age: Social Reiorm in Eoston. 1800-1900. New York: Harper and Row, 1966.

Miansergh, Nicholas. The Irish Question, 1840-1921. Revised Edition. London: Unwin University Books, 1965.

Marcus, Robert D. Grand Old Party: Political Structure in the Gilded Ase, 1880-1896. New York: Oxford University Press, 1971. 
Masters, Edgar Lee. The Tale of Chicago. New York: G. P. Putnam's Sons, 1933.

Mathews, Lois K. The Expansion of New England: The Spread of New Enrland Settlements and Institutions to the Mississiopi River, 1620-1865. Boston: Houghton Miffiin Co., 1909.

Merrill, H. A. Bourbon Leader: Grover Cleveland and the Democratic Party. Boston: Little, Brown, 1957.

Moody, T. W. (ed.). The Fenian Movement. Cork: Mercier Press, 1968.

Morgan, H. Wayne. From Hays to McKinley: National Politics, 1877-1896. Syracuse: Syracuse University Press, 1969.

(ed.) The Gilded Age: A Reappraisal. Syracuse: Syracuse University Press, 1963.

Morris, Richard K. John P. Holland, 1841-1914: Inventor of the Modern Submarine. Annapolis: U. S. Naval Institute, 1966.

Moynihan, James H. The Iife of Archbishop John Ireland. New York: Harper, 1953.

Muzzey, D. S. James G. Blaine: A Political Idol of other Days. New York: Dodd, Mead, 1934.

Neilson, James W. Shelby M. Cullom: Prairie State Republican. Urbana: University of Illinois Press, 1962.

Nelli, Humbert S. Italians in Chicago, 1880-1930. New York: Oxford University Press, 1970.

Nevins, Allan. Grover Cleveland: A Study in Courage. New York: Dodd, Wead and Co., 1932.

New World. History of the Catholic Church in IIIinois, XIX Century. Chicago: Catholic Press Co., 1900.

Norman, E. R. The Catholic Church in Ireland in the Age of Rebellion, 1859-1873. Ithaca: Cornell University Press, 1965.

Nowlan, Kevin B. The Poljtics of Repeal, 1841-50. London: Routledge and Kegan Paul, 1964.

Nye, Russell B. Midwestern Progressive Politics: A Historical. Study of Its orieins and Develonment, 1870-

1958. New York: harper and kow, 1965. 
0'Brien, Conor Cruise. Parnell and His Party, 1880-90. London: Oxford University Press, 1957.

(ed.) The Shaping of Modern Ireland. Toronto: University of Toronto Press, 1960.

O'Brien, R. Barry. The Life of Charles Stewart Parnell, 1846-1891. 2 Vols. London: Smith, Elder, and Co., 1899.

The Life of Iord Russell of Killowen. London: Thomas Nelson and Sons, n. d.

O'Connor, T. P. The Parnell Movement, with a Sketch of Irish Parties from 1843. New York: Benziger Bros., 1886 .

and McWade, R. Gladstone, Parnell and the Great Irish Struggle. Philadelphia: Hubbard Brothers, 1886.

O'Dea, John. The History of the Ancient order of Hibernians and Ladies Auxillary. 4 Vols. Philadelphia: The Ancient Order of Hibernians, 1923.

O'Faolain, Sean. King of Beggars. Dublin: Allen Figgis, 1970.

O'Hanlon, John. Irish-American History of the United States. Dublin: Sealy, Bryers, and Walker, 1906.

O'Hara, M. M. Chief and Tribune: Parnell and Davitt. Dublin: Maunsel and Co., 1919.

O'Hegarty, P. S. A History of Ireland Under the Union, 18011922. London: Methuen, 1952.

o'Luing, Sean. Freemantle Mission. Tralee, Co. Kerry: Anvil Books, 1965 .

Pahorezki, Sevina. The Social and Political Activities of William James Onahan. Washington: Catholic University of America Press, 1942.

Palmer, Norman D. The Irish Land League Crisis. New Haven: Yale University Press, 1940.

Pease, Zephaniah. The Catalpa Expedition. New Bedford, Massachusetts: G. S. Anthony, 1897.

Pierce, Bessie Louise (ed.). As Others See Chicaso. Chicago: University of Chicago Press, 1933. 
Pierce, Bessie Louise. History of Chicago. 3 Vols. New York: Alfred A. Knopf, 1937-57.

Pollard, H. B. C. The Secret Societies of Ireland: their Rise and Progress. London: P. Allen and Co., 1922.

Pomfert, John. The Struggle for Land in Ireland. Princeton: Princeton University Press, 1930.

Potter, George. To the Golden Door: The Story of the Irish in Ireland and America. Boston: Iittle, Brown, 1960 .

Putnam, James W. The Illinois and Michigan Canal: A Study in Economic History. Chicago: University of Chicago Press, 1918.

Putney, M. H. Real Estate Values and Historical Notes of Chicago from the Earliest Period to the Present Time. Chicago: n.p., 1900.

Ralph, Julian. Harper's Chicaso and the World's Fair. New York: Harper and Brothers, 1893.

Reynolds, James. The Catholic Emancipation Crisis in Ireland, 1823-1829. New Haven: Yale University Press, 1954.

Riordan, William I. Plunkitt of Tammany Hall. New York: E. P. Dutton and Co., 1963.

Roberts, Edward F. Ireland in America. New York: Putnam, 1931.

Roche, James J. The Life of John Boyle 0'Reilly. New York: Cassell Publishing Co., 1891.

Royko, Mike. Boss: Richard J. Daley of Chicago. New York: New American Library, 1971.

Ryan, Desmond. The Fenian Chief: A Biography of James Stephens, Coral Gables, Florida: University of Miami Press, 1967.

The Phoenix Flame: A Study of Fenianism and John Devoy. London: A. Barker, 1937.

Scammon, Johnathan Y. William B. Ogden. Chicago: Fergus Printing Co., 1882 .

Schlesinger, Arthur M. The Rise of the City. 1878-1898. New York: The Macmillan Co., 1933. 
Schrier, Arnold. Ireland and the American Emigration, 18501900. Minneapolis: University of Ninnesota Press, 1958 .

Schroeder, H. L. and Forbrick, C. W. Men who Have Made the Fifth Ward. Chicago: Schroeder, Forbrick, and Co., 1895.

Shannon, James P. Catholic Colonization on the Western Frontier. New Haven: Yale University Press, $195 ?$.

Shannon, William V. The American Irish. Revised Edition. New York: The Macmillan Co., 1966.

Sheehy Skeffington, Francis. Michael Davitt: A Revolutionary, Agitator, and Labour Leader. Boston: D. Estes, 1909.

Sievers, Harry J. Benjamin Harrison: Hoosier Statesman, From the Civil War to the White House, 1865-1888. New York: University Publishers, 1959.

Benjamin Harrison: The White House and After, 18891901. Indianapolis: Bobbs-iverrill Co., 1968.

Smith, Henry J. Chicago, A Portrait, New York: The Century Co., 1931.

Solomon, Barbara M. Ancestors and Immigrants: A Changing New England Tradition. Cambridge: Harvard University Press, 1956.

Stead, William T. If Christ Came to Chicago! Chicago: Laird and Lee, 1894.

Steffens, Iincoln. The Shame of the Cities. New York: Hill and Wang, 1957.

Stoddard, Lothrop. Master of Manhattan: The Life of Richard Croker. New York: Longmans, Green and Co., 1931.

Strauss, Eric, Irish Nationalism and British Democracy. New York: Columbia University Fress, 1951.

Tansill, Charles $C$. America and the Fight for Irish Freedom, 1866-1922. New York: Devin-Adair, 1957. The Foreign Policy of Thomas F. Baynard, 18851891. New York: Fordham University Press, 1940.

Tarr, Joel Arthux. A Study in Boss Poljtics: William Lorimer of Chicaro. Urbana: University of IIlinois Press, 1971 . 
Taylor, Philip. The Distant Magnet: European Emigration to the U.S.A. New York: Harper and Row, 1971.

Thernstrom, Stephan. Poverty and Progress: Social Mobility in a Nineteenth Century City. Cambridge: Harvard University Press, 1964.

Thompson, Joseph J. (ed.). The Archdiocese of Chicago. Des Plaines, Illinois: St. Mary's Training School Press, 1920.

Thornley, David. Isaac Butt and Home Rule. London: Ambassador Press, 1964.

Tierney, Michael (ed.). Daniel O'Connell: Nine Centenary Essays. Dublin: Browne and Nolan, 1949.

Tugwell, Rexford G. Grover Cleveland. New York: The Nacmillan Co., 1968.

Walker, Nabel Gregory. The Fenian Movement. Colorado Springs: Ralph Myles Publisher, 1969.

Ward, Alan J. Ireland and Anglo-American Relations, 18991921. London: The London School of Economics and Political Science and Weidenfeld and Nicolson, 1969.

Warner, Sam B. Streetcar Suburbs: The Process of Growth in Boston, 1870-1900. Cambridge: Harvard University Press, 1962.

Wendt, Iloyd and Kogan, Herman. Bosses in Iusty Chicago: The Story of Bathhouse John and Hinky Dink. BIoomington: Indiana University Press, 1967.

Werner, M. R. Tammany Hall. New York: Doubleday, Doran, and Co., 1928.

White, Terence deVere. The Road of Excess: A Biography of Isaac Butt. Dublin: Browne and Nolan, 1946.

Whyte, John H. The Independent Irish Party, 1850-1859. London: Oxford University Press, 1958.

Wittke, Carl. The Irish in America, Baton Rouge: Louisiana State University Press, 1956.

Woodham-Smith, Cecil. The Great Hunger: Ireland, 1845-49. New York: Harper and Row, 1962.

Yearley, C. K. Britons in American Labor: A History of the Influence of United Kingdom Immirants in American Labor, 1820-1914. Baltimore: Johns Hopkins University Press, 195?. 
Zeisler, Ernest B. The Haymarket Riot. Chicago: Alexander J. Isaacs, 1956 .

Zorbaugh, Harvey $w$. The Gold Coast and the Slum. A Sociological Study of Chicago's irear irorth Side. Chicago: University of Chicago Press, 1929.

Zwierlein, Frederick J. The Life and Letters of Bishop McQuaid. 3 Vols. Rochester: The Art Print Shop, 1925.

Secondary Articles

Barry, Colman (ed.). "Tour of His Eminence Cardinal Francesco Satolii, Pro-Apostolic Delegate, Through the United States (of the North) from 12 February to 13 March, 1896," United States Catholic Historical. Society, Historical Records and Studies, Vol. XIIII (1955), pp. 27-94.

Barry, P. T. "The First Irish in Illinois," Transactions of the Illinois state Historical Society (1902), pp. $63-70$.

Bogart, Ernest I. "The Population of Illinois, 1870-1910," Transactions of the Illinois State Historical Society, VoI. XXV (1917), pp. 64-75.

Brown, Thomas N. "Nationalism and the Irish Peasant, 18001848," Review of Politics, Vol. XV (1953), pp. 43539.

"The Origins and Character of Irish-American Nationalism," Review of Politics, Vol. XVIII (1956), pp. $327-58$.

Colton, K. E. "Parnell's Mission to Iowa," Annals of Iowa, Series III, Vol. XXII (1940), pp. 312-27.

De Santis, Vincent P. "Catholicism and Presidential Elections, 1865-1900," Mid-America, Vol. XI (1960), pp. 67-79.

Drury, John. "Old Chicago Neighborhoods: VII, Rogers Park," Landlords Guide, Nov. 1947, pp. 22-23, 26.

Ellis, Lewis E. "A History of the Chicago Delegation in Congress, 1843-1925," Transactions of the Illinois State Historical Society, 1930, pp. 52-145.

Fanning, Charles J. "Mr. Dooley's Bridgeport Chronicle," Chicago History, Vol. II (1972), pp. 47-57. 
Gallery, Mary Onahan (ed.). "The Diaries of William J. Onahan," Mid-America, Vol. XIV (1931), pp. 152-57.

Green, J. J. "American Catholics and the Irish Land League, 1879-1882," The Catholic Historical Review, Vol. XXXV (1949), pp. 19-42.

"Organization of the Catholic Total Abstinence Union," The Records of the American Catholic Historical Society of Philadelphia, Vol. IXI (1950), pp. 71-97.

Grob, Gerald N. "Terence V. Powderly and the Knights of Labor," Mid-America, Nov1. XXXIX (1957), pp. 39-55.

Henthorne, Sister Mary Evangela. "F'oundations of Catholic Secondary Education in IIlinois," Mid-America, Vol. XVII (1935), pp. 145-7I.

Kaufman, Martin and Hanawalt, Leslie L. "Body-Snatching in the Midwest," Michigan History, Vol. IV (1971), pp. $20-40$.

Larkin, Emmet. "The Devotional Revolution in Ireland, 185075." American Historical Review, Vol. LXXVII (1972), pp. $625-52$.

Lennon, M. J. "The Murder of Doctor Cronin," The Bell, Vol. XVIII (1952), pp. 20-28, 92-102.

McAvoy, Thomas T. "The American Catholic minority in the Later Half of the Nineteenth Century," Review of Politics, Vol. XV (1953), pp. 275-302.

MicGoorty, John P. "The Early Irish in Illinois," Illinois Catholic Historical Review, Vol. X $(1927-28), \mathrm{pp}$. $26-37$.

"The Early Irish in Illinois," Transactions of the Illinois State Historical Society, Vol. XXXIV, (I927), pp. 54-64.

McManamin, Francis G. "John Boyle O'Reilly, Social Reformer," Mid-America, Vol. XIIII (1961), pp. 36-54.

Mitchell, Arthur (ed.). "A View of the Irish in America: 1887," Eire-Ireland, Vol. IV (1969), pp. 7-12.

Moody, T. W. "Irish-American Naticnalism," Irish Historical Studies, Vol. XV (1967), pp. 438-45.

"Michael Davitt and the Pen Letter," Irish Mistorical Studies, Vol. IV (1945), pp. $224-53$. 
Moody, T. W. "The New Departure in Irish Politics, 187879." Essays in British and Irish History in Honour of James Eadie Todd, edited by T. W. Moody, et. al. London: Muller, 1949, pp. 325-33.

Morehouse, Frances. "The Irish Migration of the Forties," American Historical Review, Vol. XXXIII (1928), pp. 588-99.

O'Keefe, Thomas M. "Chicago's Flirtation with Political Nativism, 1854-1856," Records of the American Catholic Historical Society of Philadelphia, Vol. LXXXXII (1971), pp. 131-58.

Onahan, William J. "A Civil War Diary," Mid-America, Vol. XIV (1931), pp. 64-72.

Roohan, James E. "American Catholics and the Social Question, 1865-1900," United States Catholic Historical Society, Historical Records and Studies, Vol, XIIII (1955), pp. 3-26.

Ryan, Thomas F. "Orestes A. Brownson and the Irish," MidAmerica, Vol. XXXVIII (1956), pp. 156-72.

Senning, John P. "The Know-Nothing Movement in Illinois, 1854-1856," Il] inois State Historical Society Journal, Vol. VII (1914), pp. 7-33.

Stephenson, George M. "Nativism in the Forties and Fifties with Special Reference to the Mississippi Valley," Mississippi Valley Historical Review, Vo. IX, pp. 185-202.

Tarr, Joel A. "The Urban Politician as Entrepreneur," Mid-America, Vol. XIIX (1967), pp. 55-67.

"William Kent to Lincoln Steffens: Origins of Progressive Reform in Chicago," Mid-America, Vol. XIVII (1965), pp. 48-57.

Thompson, Joseph J. "The First Catholics in and about Chicago," IIIinois Catholic Historical Review, Vol. III (1921), pp. 227-40.

"The Irish in Chicago," Illinois Catholic Historical Review, Vols. II, III (April, oct. 1920), pp. 458$73 ; 46-69$.

Wiltsee, Herbert. "The Temperance Wovement, 1848-1871," Illinois State Historical Society Papers in Illinois Historical Transactions for the Year 193?, pp. 82-92. 
Unpublished Dissertations and Papers

Brown, Thomas N. "Irish-American Nationalism, 1848-1890," $\mathrm{Ph} . \mathrm{D}$. Dissertation, Harvard University, 1956.

"The Case of Doctor Cronin," Federal Writers Project Manuscript, Illinois State Historical Library.

Dillon, Patrick J. "A Study of 100 Postwar Irish Immigrants in the City of Chicago, 1953," M. A. Thesis, Loyola University of Chicago, 1954.

Fleming, George J. "Canal at Chicago," Ph. D. Dissertation, Catholic University of America, 1950.

Hamzik, Joseph. "Gleanings of Archer Road," Manuscript, Chicago Historical Society.

Local Community Research Committee, "Chicago Communities," 6 Vols. Typed Manuscript, Chicago Historical Society.

O'Grady, Joseph. "Irish-Americans and Anglo-American Relations, 1880-1888," Ph. D. Dissertation, University of Pennsylvania, 1965.

Palmer, Vivien, M. "Study of the Development of Chicago's Northside," Typed Manuscript, Chicago Historical Society.

Piper, Ruth M. "The Irish in Chicago, 1848 to 1871," M. A. Thesis, University of Chicago, 1936.

Rodechko, James Paul. "Patrick Ford and His Search for America: A Case Study of Irish-American Journalism," $\mathrm{Ph} . \mathrm{D}$. Dissertation, University of Connecticut, 1968.

Townsend, Andrew J. "The Germans of Chicago," Ph. D. Dissertation, University of Chicago, 1927.

Walsh, John P. J. "The Catholic Church in Chicago and the Problems of an Urban Society: 1893-1915," Ph. D. Dissertation, University of Chicago, 1948.

Winslow, Charles S. "Historic Goose Island," Typed Manuscript, Chicago Historical Society. 


\section{APPROVAI SHEET}

The dissertation submitted by Michael F. Funchion has been read and approved by nembers of the Department

$$
\text { of History. }
$$

The final copies have been examined by the director of the dissertation and the signature which appears below verifies the fact that any necessary changes have been incorporated and that the dissertation is now given final approval with reference to content and form.

The dissertation is therefore accepted in partial fulfillment of the requirements for the degree of Doctor of Philosophy.

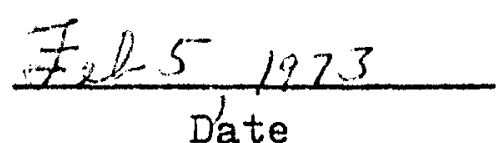

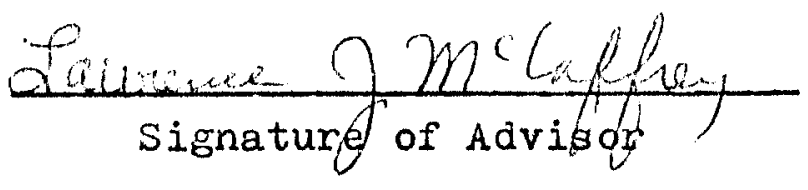

